A INGESTÃO DE ALIMENTOS E AS ORIENTAÇÕES DA ESCOLA SOBRE ALIMENTAÇÃO, SOB O PONTO DE VISTA DO ALUNO CONCLUINTE DO ENSINO FUNDAMENTAL

\title{
NeUZA MAINARDI
}

Dissertação apresentada à Escola Superior de Agricultura “Luiz de Queiroz” , Universidade de São Paulo, para obtenção do título de Mestre em CiênciasÁrea de Concentração: Ciência e Tecnologia de Alimentos.

PIRACICABA

Estado de São Paulo - Brasil

Junho - 2005 


\title{
A INGESTÃO DE ALIMENTOS E AS ORIENTAÇÕES DA ESCOLA SOBRE ALIMENTAÇÃO, SOB O PONTO DE VISTA DO ALUNO CONCLUINTE DO ENSINO FUNDAMENTAL
}

\author{
Neuza Mainardi \\ Especialista em Educação
}

Orientador: $\operatorname{Prof}^{\mathrm{a}} \operatorname{Dr}^{\mathrm{a}}$ MARIA ANGÉLICA PENATTI PIPITONE

Dissertação apresentada à Escola Superior de Agricultura "Luiz de Queiroz", Universidade de São Paulo, para obtenção do título de Mestre em CiênciasÁrea de Concentração: Ciência e Tecnologia de Alimentos.

PIRACICABA

Estado de São Paulo - Brasil

Junho - 2005 
Dados Internacionais de Catalogação na Publicação (CIP) DIVISÃO DE BIBLIOTECA E DOCUMENTAÇÃO - ESALQ/USP

Mainardi, Neuza

A ingestão de alimentos e as orientações da escola sobre alimentação, sob o ponto de vista do aluno concluinte do ensino fundamental / Neuza Mainardi. - - Piracicaba, 2005

$151 \mathrm{p}$.

Dissertação (mestrado) - - Escola Superior de Agricultura Luiz de Queiroz, 2005. Bibliografia.

1. Comportamento alimentar 2. Consumo de alimentos 3. Educação nutricional 4. Ensino fundamental 5. Estado nutricional 6. Hábito alimentar 7. Saúde escolar I. Título

CDD 642.5

"Permitida a cópia total ou parcial deste documento, desde que citada a fonte - O autor" 
Dedico este trabalho às minhas filhas Aline, Milena e Mariela, por serem estrelas de primeira grandeza a iluminar meus caminhos, dando-me forças para lutar e ir sempre em frente. 


\section{Agradecimentos}

Aos meus professores do programa de pós-graduação, pelos ensinamentos e carinho: Dr.André Ricardo Alcarde, Dr.Ernani Porto, Dra Jocelem Mastrodi Salgado, Dra Laura Martirani Alves, Dra Marisa Aparecida Bismara Regitano d' Arce, Dra Marta Fillet Spoto, Dra Silene Bruder Silveira Sarmento.

De maneira particular, aos professores:

Dra Maria Lúcia Spedo Hilsdorf (Faculdade de Educação- USP) e à amiga Walterly Accorsi, pelo encorajamento, ao sugerir-me a volta à vida acadêmica;

Dr.Sérgio Oliveira Moraes (Depto de Física) e Dra Solange Guidolin Canniatti Brazaca (Depto de Agroindústria, Alimentos e Nutrição), ambos da ESALQ-USP pela confiança, ao me apresentarem à Universidade;

Dra Marília Oetterer, professora e coordenadora do Programa de Pós-Graduação em Ciência e Tecnologia de Alimentos - ESALQ/USP, pelo incentivo, sem o que, possivelmente, eu não me aventurasse a cursar um Programa de Mestrado nessa área;

DraSolange Guidolin Canniatti Brazaca (Depto LAN - ESALQ-USP), presidente, Dr Cleiton de Oliveira (F. Educação - UNIMEP) e Dra Marina Vieira da Silva (Depto LAN - ESALQ-USP) membros da Banca Examinadora , pela valorização do trabalho.

De forma especial:

À profa Dra Maria Angélica Penatti Pipitone (Depto de Economia, Administração e Sociologia - ESALQ/USP), minha orientadora, por toda a sua bondade, dedicação, incentivos e apoio contínuos.

À minha filha Milena Mainardi Oriani, pelo apoio e amor que me demonstrou, ao reformatar tantas vezes quantas foram necessárias, a parte de computação gráfica.

À amiga Maria Elvira Bonadio, pela força encorajadora de sempre.

Aos alunos sujeitos da pesquisa , anônimos, que nos possibilitaram levantar os dados para caracterizar seus hábitos alimentares e avaliar nossas hipóteses.

Agradeço ainda:

Ao Prof Oldack Chaves, diretor regional de ensino, à coordenadora pedagógica Profa Maria Teresa Angarten, e aos srs diretores de escolas públicas e particulares participantes, pelo auxílio na coleta de dados.

Ao Comitê de Ética em Pesquisa da FOP-UNICAMP, que aprovou integralmente o trabalho, sem que a mínima retificação precisasse ser feita.

À minha irmã, Arlete Mainardi Ribeiro dos Santos e aos amigos profa. Dra. Cecília Gatti Guirado (FOP-UNICAMP), Daniela Cristina Rosseto Caroba (doutoranda Prog.Nutrição-USP), Eldad Hauzman, Profa. Diva e Leontina Cardinalli, pelo apoio.

A todos os funcionários das bibliotecas, secretarias e outros setores da ESALQ, pela presteza e atenção; de modo particular, a Beatriz Helena Giongo, revisora da formatação final do trabalho.

Muito Obrigada! Que Deus ilumine sempre os seus caminhos! 
"Quando a gente pensa que sabe todas as respostas, vem a vida e muda todas as perguntas"

(autor desconhecido). 


\section{SUMÁRIO}

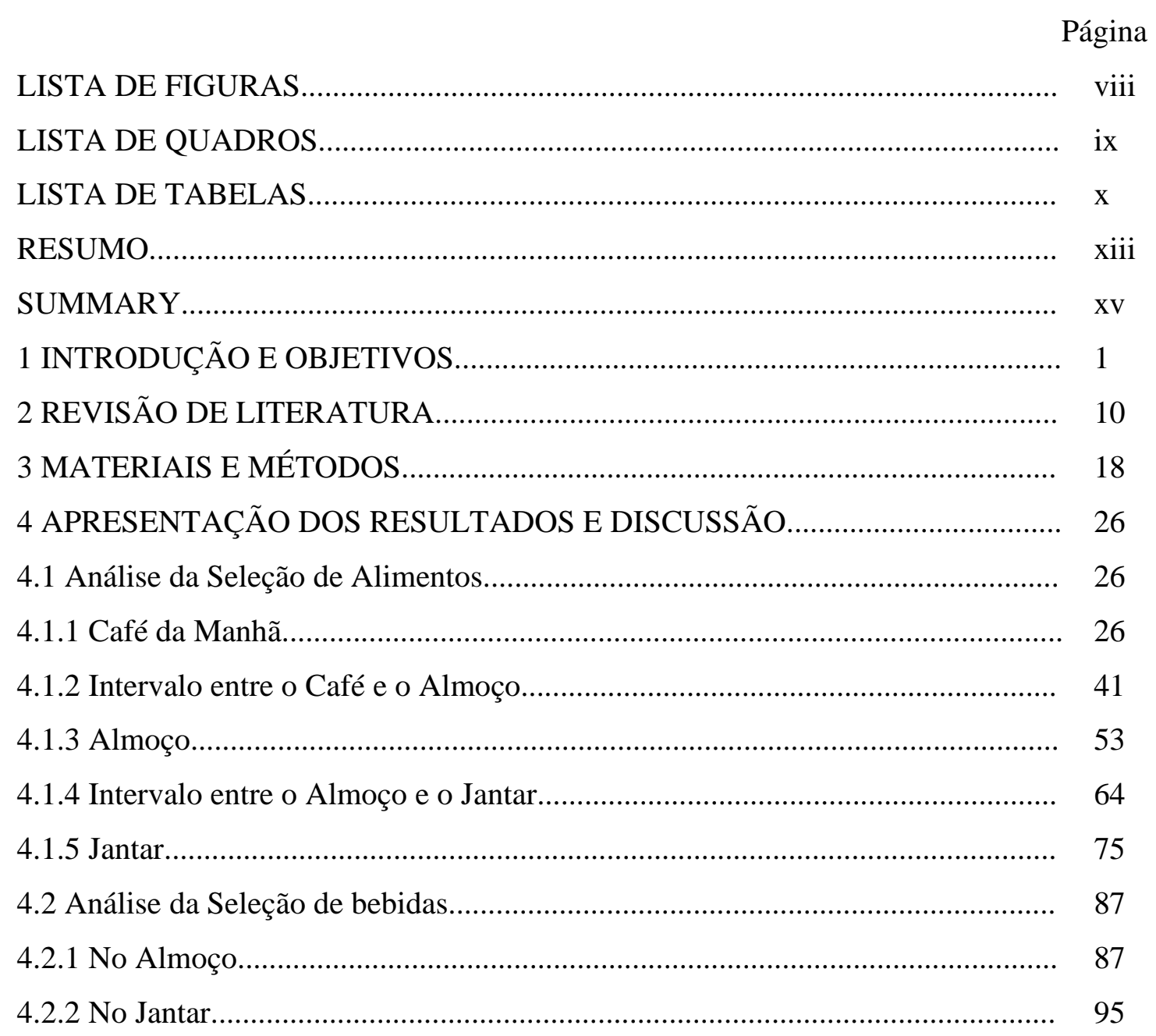

4.3 Influências na formação dos hábitos alimentares da população em estudo . 103

4.4 Informações dos alunos quanto às séries do ensino fundamental em que os assuntos Alimentos e Nutrição são ministrados em sala de

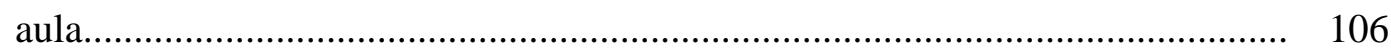

4.5 Informações quanto a matérias cujos professores trabalham Educação Alimentar e Nutricional 106

4.6. Expressão percentual de conhecimento dos alunos quanto ao que seja um 
cardápio adequado a uma refeição.

4.7 Percepções dos alunos em relação à sua massa corporal, sem qualquer menção ao Índice de Massa Corporal - IMC

4.8 IMC calculado e comparado às percepções dos alunos...................................... 112

4.9 Sugestões dos alunos para promoção da educação Alimentar e Nutricional ...... 127

4.9.1 Excertos das opiniões dos alunos quanto a Educação Alimentar e Nutricional desenvolvida na escola .................................................................................... 132

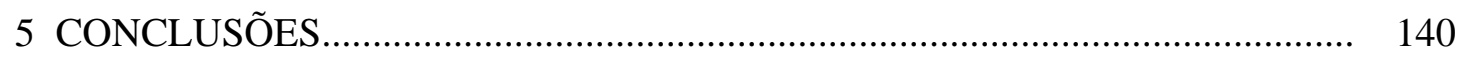

REFERÊNCIAS BIBLIOGRÁFICAS............................................................ 147

ANEXO (questionário aplicado).......................................................................... 150 


\section{LISTA DE FIGURAS}

Página

1 Alunos que têm o hábito de tomar o café da manhã........................................... 34

2 Alimentos ingeridos no café da manhã.............................................................. 36

3 Ingestão de alimentos entre o café da manhã e o almoço....................................... 47

4 Alimentos ingeridos entre o café da manhã e o almoço........................................ 48

5 Alimentos ingeridos no almoço........................................................................ 58

6 Ingestão de alimentos entre o almoço e o jantar..................................................... 69

7 Alimentos ingeridos entre o almoço e o jantar........................................................ 70

8 Alunos que se alimentam no horário do jantar...................................................... 80

9 Alimentos ingeridos no jantar........................................................................... 81

10 Ingestão de bebidas no almoço............................................................................ 90

11 Ingestão de bebidas no jantar........................................................................ 98

12 Índice de Massa Corporal (IMC) calculado ..................................................... 115

13 Comparação de massa corporal entre gêneros.................................................. 116

14 Como os alunos com I.M.C.dentro da faixa de normalidade se auto-analisam... 119

15 Como os alunos com I.M.C.abaixo da faixa de normalidade se auto -analisam. 121

16 Como os alunos com I.M.C.acima da faixa de normalidade se auto-analisam.... 123

17 Comparação entre I.M.C. e pretensão de ganho ou perda de peso...................... 125 


\section{LISTA DE QUADROS}

Página

1 Alunos existentes nas oitavas séries do Ensino Fundamental - sujeitos da pesquisa.

2 Número de sujeitos da pesquisa por zona, tipo e categoria de escolas, modalidades de curso e períodos de funcionamento.

3 Distribuição dos sujeitos da pesquisa do ensino regular por idade, sexo, peso, altura e categoria de escolas.

4 Distribuição dos sujeitos da pesquisa da educação supletiva por idade, sexo, peso, altura e categoria de escolas.

5 Concluintes do ensino fundamental, de acordo com as citações relativas ao hábito de tomar o café da manhã...

6 Percentuais de alunos que tomam café da manhã diariamente por categoria de escolas.

7 Percentuais de ingestão de principais fontes protéicas de origem animal entre alunos do período diurno no almoço.

8 Percentuais de ingestão de principais fontes protéicas de origem animal entre alunos do período diurno no jantar. 


\section{LISTA DE TABELAS}

Página

1 Comparativa entre alunos de escolas públicas e particulares de zona urbana e rural quanto aos alimentos selecionados pelos que tomam o café da manhã.....

1 A Escolas públicas A e particulares $\alpha$ 38

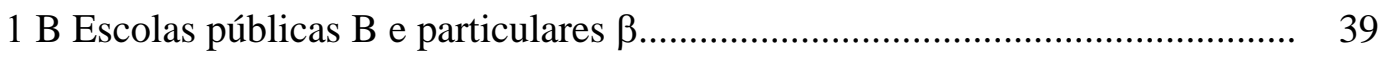

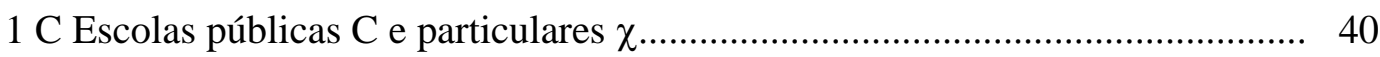

2 Comparativa entre alunos de escolas públicas e particulares, de zona urbana e rural quanto ao que ingerem entre o café da manhã e o almoço....................... 49

2 A Escolas públicas A e particulares $\alpha$.......................................................... 50

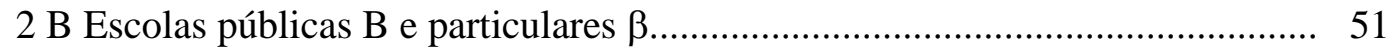

2 C Escolas públicas $\mathrm{C}$ e particulares $\chi$.............................................................. 52

3 Comparativa entre alunos de escolas públicas e particulares, de zona urbana e rural quanto aos alimentos selecionados para o almoço....................................6 60

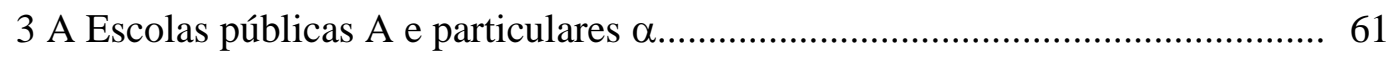

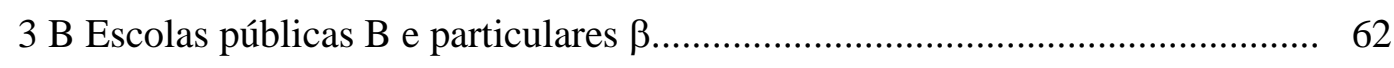

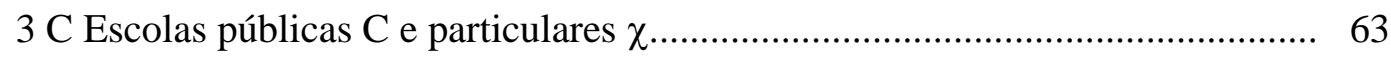

4 Comparativa entre alunos de escolas públicas e particulares de zona urbana e rural quanto aos alimentos ingeridos entre o almoço e o jantar........................ 71

4 A Escolas públicas A e particulares $\alpha$.............................................................. 72

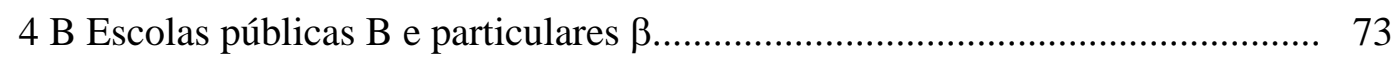

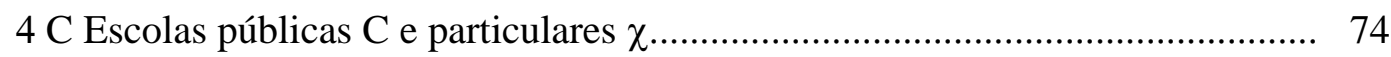

5 Comparativa entre alunos de escolas públicas e particulares de zona urbana e rural quanto aos alimentos selecionados para o jantar...................................... 83

5 A Escolas públicas A e particulares $\alpha$.......................................................... 84

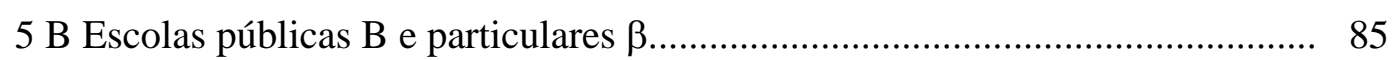

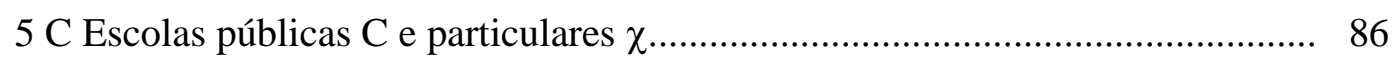


6 Comparativa quanto a bebidas ingeridas no almoço ....................................... 91

6 A Escolas públicas A e particulares $\alpha$.............................................................. 92

6 B Escolas públicas B e particulares $\beta$............................................................. 93

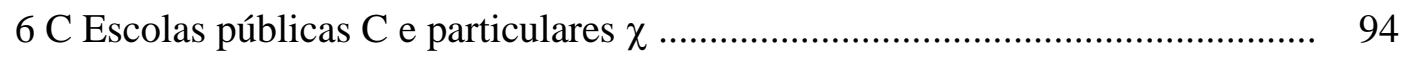

7 Comparativa quanto a bebidas ingeridas no jantar ........................................... 99

7 A Escolas públicas A e particulares $\alpha$......................................................... 100

7 B Escolas públicas B e particulares $\beta$........................................................... 101

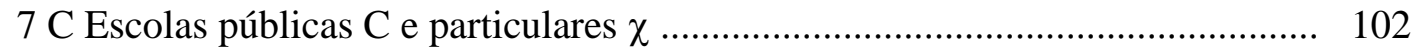

8 Número de opiniões dos alunos quanto ao fator que mais interferiu na formação de seus hábitos alimentares............................................................ 104

9 Opiniões sobre o fator que mais interferiu na formação dos hábitos alimentares por categoria de escolas................................................................ 105

10 Informações sobre as séries em que os assuntos Alimentos e Nutrição têm sido ministrados em sala de aula.................................................................. 107

11 Informações quanto a professores que têm trabalhado Educação Alimentar e Nutricional no ensino fundamental

12 Números e percentuais de alunos que demonstram conhecimento relativo quanto ao que seja um cardápio adequado.

13 Opiniões dos alunos quanto a sua massa corporal sem qualquer cálculo ou referência ao Índice de Massa Corporal.

14 IMC calculado

15 Alunos que não puderam ter o IMC calculado

16 Como os alunos com IMC dentro da faixa de normalidade se auto analisam

17 Como os alunos com IMC abaixo da faixa de normalidade se auto analisam 
18 Como os alunos com IMC acima da faixa de normalidade se auto analisam...

19 Comparativa entre IMC e pretensão de ganho ou perda de peso

20-Número de alunos que apresentam sugestões para a escola poder ajudar mais os jovens.

21-Sugestões dos alunos do período diurno para a escola melhor atendê-los

22-Sugestões dos alunos do período noturno para a escola melhor atendêlos. 


\section{A INGESTÃO DE ALIMENTOS E AS ORIENTAÇÕES DA ESCOLA SOBRE ALIMENTAÇÃO, SOB O PONTO DE VISTA DO ALUNO CONCLUINTE DO ENSINO FUNDAMENTAL}

Autor: NEUZA MAINARDI

Orientador: Prof ${ }^{\mathrm{a}} \operatorname{Dr}^{\mathrm{a}}$ MARIA ANGÉLICA PENATTI PIPITONE

\section{RESUMO}

Embasada na Constituição da República Federativa do Brasil, entra em vigor em 20/12/96 a Lei Federal 9394/96 que define as Diretrizes e Bases da Educação Nacional. A seguir, em 1998, são estabelecidos pelo Ministério da Educação e do Desporto (MEC), Parâmetros Curriculares Nacionais (PCN), e propostos Temas Transversais a serem trabalhados em todas as séries e por todos os docentes do Ensino Fundamental. Os temas transversais são: Saúde, Meio Ambiente, Trabalho e Consumo, Orientação Sexual, Ética e Pluralidade Cultural. A Educação Alimentar e Nutricional, de acordo com os PCN, se envolve nos temas Saúde e Consumo e apresenta um vasto espaço de ações educativas para o Ensino Fundamental. Partiu-se da hipótese de que os interesses dos alunos não vêm sendo contemplados na escola, quanto a Educação Alimentar e Nutricional. Pretendeu-se, na presente pesquisa, verificar quais alimentos têm sido preferidos por 1.414 alunos concluintes do ensino fundamental, no dia-a-dia e se a escola os vem atendendo em suas dúvidas, oferecendo-lhes orientações sobre o assunto em todas as séries do ensino fundamental, como prevê a legislação; verificou-se, pelas informações dos alunos, em que série(s) escolar(es) recebem orientações sobre os alimentos; quais professores de quais matérias os têm orientado; se têm noção de um cardápio que seja adequado às suas necessidades; se as cantinas escolares vendem produtos 
alimentares recomendados pelos professores em sala de aula ou trabalham em dissonância com as recomendações nutricionais. Conclui-se, confirmando nossa hipótese, que, na opinião dos alunos, a contribuição da escola tem sido pequena quanto a Educação Alimentar e Nutricional; alunos de zona urbana e rural, do sexo masculino e feminino, da rede regular e da educação supletiva, do período diurno e noturno, de escolas públicas e particulares apontam a família como a principal formadora de seus hábitos alimentares; os alunos do período noturno, tanto da rede regular quanto da educação supletiva são os que mais demonstram terem sentido a influência da escola, neste particular. Os alunos apresentam sugestões para que a escola atenda melhor os seus interesses quanto à educação alimentar. 


\title{
“THE INGESTION OF FOOD AND THE ORIENTATION BY SCHOOL ABOUT ALIMENTATION, BELOW THE POINT OF VIEW OF THE GRADUATE FUNDAMENTAL COURSE STUDENTS”
}

\author{
Author : NEUZA MAINARDI \\ Adviser: Prof ${ }^{\mathrm{a}}$ Dr $^{\mathrm{a}}$ MARIA ANGÉLICA PENATTI PIPITONE
}

\section{SUMMARY}

Founded on Brazilian Constitution, go into effect in december, $21^{\text {st }}$, the federal norm 9394/96 with the directrix and support of the National Education. After, in 1998, are established by the Education and Sport Ministry, a National Curriculum Parameters (PCN) and proposed Transversal Themes to be worked at all levels of Fundamental Course for every teachers. The themes are: Health, Environment, Work and Consumption, Sexual Orientation, Ethic and Cultural Plurality. The Food and Nutritional envelop the Work and Consumption themes, and present a vast space of educatives action for the Fundamental Course, in accord with the PCN. We supose the school don't attent the interest of the students about food ad nutritional education; we check in this research what 1.414 students of terminal fundamental course think about this theme : which foods they eat, which levels at school they receive orientation about foods, which teachers give them the orientations, if they know what is important to eat to attent their necessities, if the school canteen sells the recommended food by the teachers at classes or work in dissonance with the nutritional recommendation. The hypothesis is confirmed. We conclude the pupils think the school haven't very influence at 
their food habits; pupils of urban and rural zone, male and female, of regular and suplementary schools, of public and particular institution, of diurnal and nocturnal period say the family is the more important adviser in this theme. The pupils of noturnal period see some influence of school. The pupils suggest some ideas to elevate their level of knowledge in this área at school. 


\section{INTRODUÇÃo}

A Constituição da República Federativa do Brasil em vigor, promulgada em 1988, tem como objetivos fundamentais zelar pela construção de uma sociedade livre, justa e solidária, que garanta o desenvolvimento nacional; objetiva erradicar a pobreza e a marginalização, reduzindo as desigualdades sociais e regionais, promovendo o bem de todos, sem preconceitos de origem, raça, sexo, cor, idade e quaisquer outras formas de discriminação.

Nela embasada, entra em vigor em 20 de dezembro de 1996, a Lei Federal 9394/96 que define novas Diretrizes e Bases da Educação Nacional, dividindo-a em Educação Básica e Superior, evidenciando a necessidade da escola vincular-se ao mundo do trabalho e à prática social. A Educação Básica, por sua vez, envolve a Educação Infantil, o Ensino Fundamental e o Médio.

Em 1998, a Secretaria de Educação Fundamental do Ministério da Educação e Desporto (MEC) vem estabelecer os Parâmetros Curriculares Nacionais (PCN), que apresentam objetivos precípuos a serem trabalhados nas diferentes áreas de formação escolar básica, do ensino fundamental e médio, respectivamente com 8 e 3 anos de duração, normalmente. Deve ser trabalhada uma Base Nacional Comum que inclui, desde o início da educação sistemática, o estudo da língua portuguesa, matemática, conhecimentos do mundo físico e natural, bem como da realidade social e política, especialmente do Brasil, arte e educação física; também prevê uma parte diversificada a partir da $5^{\mathrm{a}}$ série do ensino fundamental, com matérias que atendam as necessidades da realidade em que a escola está inserida; para esse atendimento surgem os Temas Transversais a serem trabalhados por todos os professores em todas as áreas do ensino fundamental e em todas as séries ou ciclos, traduzindo a exata medida de que devem 
permear todo o currículo, sem se constituir numa disciplina em si. Os temas transversais são: Saúde, Meio Ambiente, Ética e Cidadania, Trabalho e Consumo, Orientação Sexual e Pluralidade Cultural. Estes temas visam construir uma escola voltada para a formação de cidadãos, uma escola que amplie e aprofunde um debate educacional, envolvendo os pais dos alunos, as forças políticas e a sociedade, uma escola em que os docentes e especialistas da educação reflitam sobre a prática pedagógica, dando origem a uma transformação positiva no sistema educativo brasileiro.

É fundamental que haja coerência entre teoria e prática, que o processo educativo realmente interfira, conscientize, transforme. Isso possivelmente ocorrerá com união de esforços entre todos os profissionais que atuam na escola: diretores, professores, coordenadores, inspetores de alunos, recreacionistas, cantineiros, faxineiros, porteiros e outros; todos devem refletir sobre a própria atuação, estando predispostos a inovar, a transformar-se para transformar, respeitando todos e cada um na sua individualidade e, ao mesmo tempo, envidando esforços para que cada elemento envolvido se preocupe não só com o próprio bem estar, mas também com o bem estar do seu próximo.

Daí a necessidade da competência técnica dos especialistas da educação, responsáveis pela manutenção desse elo de compromisso com a causa educativa; que sejam capacitados a promover um trabalho transdisciplinar, onde a participação coletiva é, não só importante, como absolutamente necessária, para se maximizar bons resultados.

Quatro pilares sustentam a educação no mundo todo: aprender ser, aprender fazer, aprender viver juntos e a conhecer; há uma transrelação que liga esses pilares, dentro de uma ética que considera o ser humano numa tríplice realidade: como indivíduo, como parte da sociedade e como parte da espécie (Morin, 2002).

Os direitos, pela legislação, são os mesmos para todos, mas percebe-se que, na prática social, ocorre dicotomia com a teoria. A sociedade brasileira tem se mostrado autoritária, com relações políticas paternalistas e clientelistas, marcadas por privilégios que reproduzem um altíssimo nível de desigualdade, injustiça e exclusão social. Grande parte do povo brasileiro é excluída do processo de tomada de decisões, cumprindo-lhe 
apenas acatar e cumprir deveres; não tem consciência crítica, aceita tudo passivamente, sem reivindicar seus direitos; encontra-se num estado de consciência primitivo.

A história da Educação Alimentar e Nutricional no Brasil é bastante recente e tem sólidas raízes no município de Piracicaba (SP), um município com 329.158 habitantes (IBGE, 2000), distante 160 Km da capital de São Paulo. Em 13 de março de 1922 chegam em Piracicaba, “movidas do propósito de fundar na cidade uma Escola de Economia Doméstica”, as irmãs franciscanas. Vieram de Graz (Áustria), trazidas por Lydia de Souza Rezende, filha do Barão de Rezende, que tendo estado na Europa uma vez finda a primeira guerra mundial, encantou-se com a “nova modalidade pedagógica, que vinha sendo apontada como a base do progresso na França, Bélgica e Alemanha; o Jornal de Piracicaba deu a entender que o acontecimento preenchia uma lacuna em nosso meio” (Perecin, 1993 p.20); a escola foi fundada em 11 de junho do mesmo ano, funcionando na Vila Rezende, numa casa cedida, onde ainda funciona o Instituto Baronesa de Rezende, sob a direção das irmãs . Instala-se em Piracicaba (SP) o curso de Economia Doméstica e Agrícola, possivelmente a primeira escola onde se ministra Educação Alimentar no país, com o objetivo de orientar as moças de famílias abastadas em preparação ao casamento, considerado então, de fundamental importância. Essa escola segue o modelo europeu, ensinando receitas utilizadas no velho mundo. A educação para o consumo faz parte do curso oferecido; valor a ser gasto em cada receita é calculado; o cuidado com as características organolépticas é enfatizado. Trata-se de uma necessidade, devido à transformação da sociedade brasileira: as famílias patriarcais cedem espaço às famílias nucleares burguesas, auto-suficientes e isoladas”(D’ Incao, 1989); as jovens donas de casa, não tendo a mãe ou sogra ao lado, precisavam estar aptas a cozinhar, uma de suas obrigações de casadas; muitas delas se limitavam a orientar o trabalho das cozinheiras contratadas, muitas trazidas do exterior, sem entender o português e nem as patroas a sua fala; o Instituto oferece, além das aulas de arte culinária, higiene, bordado, pintura e música instrumental, especialmente piano, violino e, posteriormente, acordeão. 
Com a primeira Lei de Diretrizes e Bases da Educação Nacional (LDB) $-n^{\circ}$ 4.024/61, a Economia Doméstica é introduzida nas escolas públicas do Estado de São Paulo, nas duas últimas séries do ginásio, (hoje o equivalente ao ensino de $7^{\mathrm{a}}$ e $8^{\mathrm{a}}$ séries do Ensino Fundamental). Na década de 60, o Serviço Social da Indústria (SESI) mantém, inclusive em Piracicaba (SP), curso público, gratuito, de educação alimentar. É mantido, unicamente no município de Piracicaba (SP), um Curso de Formação de Professores com Especialização Rural, na Escola Estadual "Prof José de Mello Moraes”, instalada nas dependências da Escola Superior de Agricultura "Luiz de Queiroz", orientando os futuros professores com noções de Agricultura, Zootecnia, Tecnologia de Alimentos, com aulas teóricas e também com práticas agrícolas orientadas; as disciplinas "Tecnologia de Alimentos" e "Higiene e Saúde”, inclusive com aulas práticas e estágios (em Hospitais, Centros de Puericultura e de Saúde) são disciplinas integrantes do Curso. À luz da mesma Lei de Diretrizes e Bases, foi criado em 1967, o Curso Superior de Ciências Domésticas, que funcionou até 1996 na "Escola Superior de Agricultura Luiz de Queiroz” - ESALQ - Campus da Universidade de São Paulo - USP, em Piracicaba (SP). Muito provavelmente, outros cursos ligados a alimentos e nutrição foram criados no país.

Outra reforma do ensino acontece no país a partir da Lei Federal nº 5.692/71, dando ênfase ao ensino profissionalizante de caráter compulsório e na preparação para o trabalho. O Serviço Social da Indústria (SESI), o Serviço Nacional de Aprendizagem Comercial (SENAC) e todo o sistema de cursos de aprendizagem no trabalho e qualificação profissional pra ele, se consolida; surgem cursos inovadores, inclusive na área de alimentos: garçom, cozinheiro, confeiteiro, bar-man entre outros, mesmo porque com a nova estrutura social e a mulher se dedicando ao trabalho fora do lar, há necessidade de abertura de muitos restaurantes, uma vez que as refeições já não são feitas sempre em casa.

A Lei Federal 7.044/82 retira a obrigatoriedade do ensino médio ser profissionalizante, pois, além de não se contar com professores devidamente habilitados, as escolas não contavam com laboratórios para as aulas práticas necessárias. 
A mais recente Lei de Diretrizes e Bases da Educação Nacional - Lei Federal 9.394/96, prevê que se atenda peculiaridades regionais no tocante a abertura de novos cursos; quanto à educação profissional ou técnica, essa Lei confirma a não obrigatoriedade do ensino médio ser profissionalizante.

Ao final da década de 60, a legislação pertinente à área de nutrição e alimentos, bem como as relações de consumo de gêneros alimentícios também se organizam no país, dando evidentes sinais de que o consumidor deve ter seus direitos respeitados, em benefício de sua saúde; surgem as primeiras legislações sobre alimentos no Brasil. O Decreto-Lei 986 de 21/10/69 institui Normas Básicas sobre Alimentos e Bebidas; o Ministério da Agricultura e da Saúde passam a ser agentes fiscalizadores de produtos agrícolas; a indústria nacional se desenvolve e também a alimentícia. A Lei Federal 8078/90 - Código de Defesa do Consumidor, é promulgada visando proteger o consumidor nas relações comerciais. A Lei Federal 9.782 de 26/ 01/99 define o sistema nacional de vigilância e cria a Agência Nacional de Vigilância Sanitária - ANVISA, no intuito de proteger a saúde do consumidor. Pela Portaria 710 de 10, publicada no Diário Oficial da União em 11/6/99, é aprovada a Política Nacional de Alimentação e Nutrição. No ano de 2.000 passa a ser exigência, a especificação dos ingredientes na rotulagem dos produtos. Muitas Portarias, Resoluções, Decretos, Decretos-Lei e Leis regulamentam a circulação de Alimentos e Bebidas no país, visando a segurança alimentar e a preservação da saúde.

O objetivo da Educação Alimentar, a longo prazo, é habilitar os indivíduos a tomarem decisões sobre nutrição de acordo com conhecimentos científicos, assim como também levando em consideração os seus próprios objetivos, valores e estilo de vida. Tem como meta a procura do desenvolvimento de conhecimentos, habilidades e destrezas para o auto-cuidado da saúde, com a prevenção de riscos (Caroba, 2002).

A escola é o espaço ideal para o desenvolvimento de conhecimentos, atitudes e habilidades. Quanto mais cedo se iniciar a Educação Alimentar, maior será a probabilidade de se influir favoravelmente na formação de hábitos desejáveis.

É preciso minimizar o efeito da propaganda e da mídia em geral, que veicula um padrão de consumo alimentar comprometido com os interesses dominantes. Deve-se 
deixar à disposição dos alunos, os conhecimentos sobre esta área e esperar que eles se apropriem desses conhecimentos, analisando-os a ponto de chegar a uma fase de síntese, que corresponde a um comportamento alimentar reflexivo e autônomo.

No trabalho educacional é preciso buscar soluções com uma práxis alterada qualitativamente pela incorporação dos novos conhecimentos (Saviani, 1983).

O Programa de Merenda Escolar, hoje conhecido como Programa Nacional de Alimentação Escolar, foi criado em meados da década de 50, sob clara influência das características políticas, sociais, econômicas e ideológicas da época, numa concepção ingênua que resolveria os problemas nutricionais e o fracasso escolar; surge a falsa premissa de que criança desnutrida não aprende; é uma interpretação imobilista e fatalista do desempenho escolar, considerando os professores impotentes, diante de alunos desnutridos.

Há de se considerar que é impossível a merenda escolar acabar com a desnutrição, uma vez que objetiva apenas complementar necessidades alimentares diárias dos escolares, no período em que se encontram na escola (Pipitone, 1999). Convém lembrar também que a merenda escolar não é um programa paliativo e sim uma proposta de atenção a direitos da criança de sentir-se fisicamente bem durante o período escolar; uma criança desnutrida teria morrido antes de chegar à idade escolar (Moysés e Collares, 1995).

A merenda escolar constitui-se de uma refeição balanceada, oferecida nas escolas públicas, gratuitamente, no horário do intervalo entre aulas, geralmente na metade do período em que os alunos ficam na escola. No período diurno, todos os alunos contam com essa alimentação escolar; no período noturno são apenas algumas escolas que oferecem o benefício.

Dentre os objetivos do Programa, destacam-se o aprimoramento dos hábitos alimentares, a melhoria das condições nutricionais e das condições de aprendizagem, a redução dos índices de ausências, repetências e evasão escolar (Silva, 2000).

Uma das necessidades das pessoas que trabalham com alimentação é fazer com que o alimento seja de boa qualidade e aceito; com a descentralização da merenda é mais fácil oferecer uma refeição balanceada e agradável aos gostos das crianças. A idade 
escolar (dos 7 aos 14 anos) caracteriza-se por um período de crescimento, com exigências nutricionais altas devido o metabolismo ser muito mais intenso e alto gasto energético pela grande atividade corporal e mental. Nesse período o ser humano é marcado por acentuada mudança física, emocional, cognitiva e social; é uma fase crítica para o desenvolvimento de atividades e comportamentos relacionados à dieta (White, 1997).

A merenda escolar, a educação nutricional e a cantina são alternativas a serem melhor exploradas por educadores e pais (Pipitone, 1999).

Os alunos precisam conhecer os grupos de alimentos e suas funções no organismo humano, mas somente o aspecto biológico não é decisivo.

“A motivação dos alunos em relação ao tema educação nutricional está positivamente relacionada à capacidade do professor(a) de inovar no aspecto de estratégias de ensino. Experiências de implantação de uma horta didática, lanches comunitários e feiras educativas são exemplos de experiências de boa integração dos escolares com os temas de nutrição e alimentação.” (Pipitone, 2003 p.80).

Os professores precisam informar-se bem, quanto às orientações da pirâmide alimentar a respeito da qualidade e quantidade de alimentos a ingerir, para poder discutir o assunto com mais propriedade em salas de aula.

Os pais dos alunos, devem procurar inteirar-se dos estudos dos filhos nesse assunto específico, auxiliá-los em casa, comprando alimentos saudáveis e orientando-os quanto ao quê e quanto de alimentos ingerir; é interessante que conversem com os filhos quanto aos interesses ocultos das propagandas veiculadas sobretudo, pela televisão.

É importante que nossas escolas ofereçam uma educação comprometida com uma cidadania ativa, onde os alunos sofram influência do meio, podendo também nele interferir. A Educação Alimentar e Nutricional deve ser incluída nos Temas "Saúde” e “Consumo e Trabalho”. É preciso bem formar os alunos, para que possam ser agentes, construtores do próprio conhecimento e bem estar, vivenciando situações que os capacitem a ter uma vida digna, com criticidade e ação consciente em suas decisões de consumo. 
Acredita-se que há muito por ser feito quanto a Educação Alimentar e Nutricional, em benefício da saúde da população brasileira. Trata-se de questão complexa; atualmente, as mães de família passam pouco tempo ao lado dos filhos para orientá-los; grande parte das refeições são feitas fora de casa; além disso, a maioria das mães desconhece o conveniente quanto às necessidades alimentares diárias; a mídia faz propaganda de alimentos atraentes, mas nem sempre nutritivos e convenientes, ocorrendo o mesmo nas cantinas escolares; neste mesmo sentido, os atuais cursos de formação de professores têm conferido pouca atenção para uma discussão reflexiva em torno do tema alimentação e nutrição e suas implicações na saúde dos escolares.

Nessa pesquisa, objetivou-se analisar hábitos alimentares e opiniões de alunos concluintes do ensino fundamental, verificando-se em termos percentuais:

- quais alimentos consomem no dia-a-dia;

- o conhecimento dos alunos quanto a seleção de alimentos na composição de um cardápio adequado a uma refeição;

- quem, na visão dos alunos, vem exercendo maior influência na formação desses conceitos: a família, a escola ou a TV;

- em que séries e por professores de quais disciplinas a educação alimentar vem sendo trabalhada;

- como os alunos se sentem em relação à sua massa muscular, sem qualquer cálculo ou referência ao Índice de Massa Corporal;

- o Índice de Massa Corporal - IMC - dos alunos em estudo, com peso e altura auto-referidos; comparar com o que pensam os alunos sobre si mesmos;

- as diferenças e/ou semelhanças entre as respostas de alunos das escolas públicas e particulares, da rede regular de ensino e da educação supletiva, da 
zona urbana e rural, do período diurno e noturno, do sexo masculino e do feminino.

A partir da solicitação de sugestões feitas aos escolares, verificar em termos qualitativos, quais são as expectativas e os interesses de aprendizagem dos alunos da rede regular de ensino diurno (adolescentes) e da rede regular de ensino noturno e educação supletiva (predominantemente adultos), quanto a Educação Alimentar e Nutricional na escola. 


\section{REVISÃO DE LITERATURA}

Nos dias atuais, não só a questão da desnutrição causa preocupação no meio científico, mas também a obesidade.

A situação epidemiológica-nutricional no mundo e também no Brasil vem se modificando ao longo dos anos. A desnutrição energético-proteica vem diminuindo gradualmente e os níveis de obesidade aumentando. Essa transição nutricional reflete os padrões de mudanças nas dietas de indivíduos e populações, com elevado consumo de alimentos de origem animal, de açúcares e farinhas refinadas, baixo consumo de cereais integrais e fibras, associados à diminuição da atividade física, favorecendo o aumento da prevalência da obesidade em crianças e adultos (Caroba, 2002).

Há traços marcantes e preocupantes na evolução do padrão alimentar no Brasil:

“uma tendência ascendente da participação relativa de lipídios na dieta do Norte e Nordeste, o aumento do consumo de ácidos graxos saturados em todas as áreas metropolitanas do país, ao lado da redução do consumo de carboidratos completos, da estagnação ou redução do consumo de leguminosas, verduras, legumes e frutas e do aumento do consumo já excessivo de açúcar; há mudanças que podem indicar a adesão da população a dietas mais saudáveis: declínio no consumo de ovos e recuo discreto da elevada proporção de calorias lipídicas no Centro-Sul do país” (Monteiro et al, 2000 - p. 2).

“Observou-se intensificação do consumo relativo de carnes, de leites e de seus derivados (exceto manteiga) em todas as áreas metropolitanas, enquanto o consumo de ovos passou a declinar, sobretudo no Centro-Sul do País. Leguminosas, raízes e tubérculos tenderam a se estabilizar no Centro- 
Sul ou mesmo a se elevar ligeiramente no Norte-Nordeste. A participação relativa de açúcar refinado e refrigerantes cresceu em todas as áreas, sendo que a participação de óleos e gorduras vegetais manteve-se constante no Norte-Nordeste e declinou intensamente no Sul” (Monteiro et al, 2000 - p. 02).

Os danos para a saúde podem decorrer do consumo insuficiente de alimentos desnutrição, ou do consumo excessivo - obesidade (Monteiro, 2000). Preocupam-nos as duas faces da questão.

A desnutrição, em inúmeros estudos, tem sido relacionada ao resultado da interação de uma multiplicidade de variáveis ambientais, econômicas e sociais (Valente, 1989).

Quanto à obesidade é interessante lembrar que, se presente na adolescência, é um fator preditivo da obesidade no adulto (Fonseca et al, 1998). Deve ser considerado que os adolescentes não podem ser tidos como um grupo homogêneo, pois em matéria de consumo alimentar, existem acentuadas diferenças culturais; eles vivem vários mundos, sendo três básicos: o da casa, o da escola e o dos amigos; há um quarto mundo, o do trabalho, que amplia a heterogeneidade entre eles (Spyckerelli,Y et al, 1991). Na busca da identidade, da independência que acreditam alcançar através do trabalho remunerado, é provável que haja alterações no comportamento alimentar desses jovens (Gambardella, 1995).

A prática de alimentar-se diante da televisão e enquanto se usa o computador pode ser prejudicial à saúde, pois além de haver maior ingestão de alimentos, a inatividade física gera um desbalanço energético, sendo fator contribuinte para a obesidade (Gambardella, 1999). As conseqüências da obesidade são biológicas e também psicológicas, podendo prejudicar o auto conceito e, a longo prazo, contribuir para a instalação de doenças cardiovasculares, hipertensão, hiperlipidemia e diabetes. (Ziwian, 1999).

A obesidade resulta de um desequilíbrio entre atividade física reduzida e excesso de consumo de alimentos densamente calóricos (Fonseca et al, 1998); o número de horas que um adolescente passa assistindo TV é um importante fator associado a ela, 
acarretando um aumento de $2 \%$ na prevalência da obesidade para cada hora adicional de televisão assistida por jovens (Strasburger, 1999).

A esse respeito, assim se manifestam:

“A TV como atividade principal de lazer, age diminuindo as horas gastas com atividades esportivas, influenciando a compra de alimentos pelos pais e transtornando os hábitos alimentares das crianças” (Pipitone et al 2004 - p. 12).

"A saúde dos indivíduos depende de fatores como estado nutricional, disponibilidade de alimentos, condições de saneamento ambiental, renda, educação, acesso aos serviços de saúde, segurança alimentar, enfim de políticas econômicas, agrícolas, de educação e de saúde” (Caroba, 2002 - p. 1).

Disso decorre que o papel da família associado à escola e partilhado pela mídia tem resultado na educação para o consumo de alimentos apresentada às crianças e adolescentes. “A família e a escola partilham com as instituições midiáticas uma responsabilidade pedagógica” (Setton, 2002 - p. 107).

Os resultados da Pesquisa de Orçamentos Familiares - POF, realizada pelo Instituto Brasileiro de Geografia e Estatística (IBGE) em 2002 e 2003, revelam que o brasileiro mudou seu padrão alimentar. Os gastos das famílias brasileiras com alimentação ocupam o segundo lugar da despesa total familiar, representando na média nacional, 21\%, superados apenas pelas despesas com habitação (35\%). E quase um quarto da despesa média familiar com alimentação é destinada a refeições feitas fora de casa; daí a importância da promoção da alimentação saudável nas instituições públicas e/ou privadas, notadamente as escolas.

Segundo a mesma pesquisa, os principais itens de consumo no país são:

Zona Urbana:

$1^{\circ}$ carnes $(18,3 \%)$

$2^{\circ}$ leite e seus derivados (11,9\%)

$3^{\circ}$ panificados (11\%)

$4^{\circ}$ cereais e leguminosas $(10,4 \%)$

$5^{\circ}$ bebidas e infusões (8,5\%)
Zona Rural:

$1^{\circ}$ carnes (20\%)

$2^{\circ}$ cereais e leguminosas $(16,9 \%)$

$3^{\circ}$ leite e derivados, farinhas e

féculas $(9,1 \%)$ de cada grupo

$4^{\circ}$ ovos e aves (8\%) 
Ainda foi detectado que houve, nos últimos anos, aumento de despesas com bebidas e infusões como refrigerantes, cervejas e chopes, em detrimento dos gastos com frutas. Cabe ressaltar que esse é um aspecto que vem comprovar tendências de alterações de hábitos alimentares observadas atualmente no Brasil, que são traduzidas pela freqüente troca de alimentos naturais, mais saudáveis, por alimentos industrializados, muitas vezes, mais ricos em açúcares e gorduras.

Mais da metade das famílias investigadas na pesquisa do IBGE avaliaram que têm quantidades suficientes de alimentos; porém 73\% declararam ter algum grau de insatisfação quanto ao tipo de alimentos que consomem; compram o que seus rendimentos permitem comprar, o que nem sempre é o que satisfaz as expectativas do indivíduo.

O excesso de peso atinge 38,8 milhões de brasileiros adultos, sendo que desse total, 10,5 milhões se encontram obesos. A pesquisa revela que "a população brasileira adulta, quando observada no seu todo, não está exposta aos riscos da desnutrição, sendo a taxa de $4 \%$ compatível com os padrões internacionais na proporção esperada de indivíduos que são constitucionalmente magros” (IBGE 2002-2003).

Saúde é um direito universal e a educação para a saúde deve fazer parte do dia-adia da escola, de forma contextualizada e sistemática, para que possa haver formação de hábitos e contribuir para que os alunos tenham vida mais saudável. Espera-se que possa haver transformação de atitudes, o que não é fácil de se conseguir. É interessante que não haja consumismo desenfreado nem desnutrição, sendo importante que a escola adote medidas práticas e exemplares para promoção da educação nutricional que favoreça o padrão de consumo alimentar dos alunos e, sobretudo, a saúde de todos.

A nutrição e a alimentação trabalhadas no ensino fundamental, geralmente na disciplina de ciências pode ter como objetivo:“possibilitar ao ser humano assumir com plena consciência a responsabilidade pelos seus atos relacionados à alimentação. $\mathrm{O}$ educador em nutrição deve fortalecer os educandos (alunos, clientes, pacientes, coletividade, comunidade) para que eles passem a agir em relação aos alimentos e à alimentação de forma a prescindir, cada dia mais, das intervenções profissionais. A educação nutricional não é uma ferramenta mágica para levar o educando a obedecer a 
dieta, pelo contrário, ela deve ser conscientizadora e libertadora, por isso deve buscar justamente o oposto: a autonomia do educando” (Boog, 1995).

Como vem sendo a atuação da escola na educação para o consumo de alimentos?

É objetivo que os Temas Transversais estabelecidos pelos Parâmetros Curriculares Nacionais sejam discutidos nas escolas por todos os professores, de todos os níveis, com diferentes tratamentos didáticos, por abordarem questões sociais, dandolhes a mesma importância das outras áreas do currículo. Os temas foram selecionados segundo os critérios: urgência social, abrangência nacional, possibilidade de ensino e aprendizagem na educação fundamental ( $1^{\mathrm{a}}$ a $8^{\mathrm{a}}$ séries $)$, que viessem favorecer a compreensão da realidade e maior participação social. Todos os docentes, independentemente da matéria que lecionam, devem incluir os Temas Transversais em discussão, aproveitando as oportunidades que surgem ou criando situações em sala de aula, para aplicá-los devidamente, num trabalho contínuo, integrado, transdisciplinar.

O objetivo da educação nutricional é ajudar os indivíduos a estabelecer práticas e hábitos alimentares adequados às necessidades do organismo; o educador deve criar o desejo do educando mudar a sua forma de alimentação (Bosley, 1976).

Os professores devem dar bons exemplos, agindo com ética e respeito a todos, valorizando a saúde, não fumando, não bebendo, tendo bons hábitos alimentares e dialogando sobre o assunto com os educandos. Contudo, o que dizer da preparação dos professores para o desenvolvimento da educação alimentar e nutricional nas escolas de ensino fundamental? Como libertar os professores dos conteúdos restritos dos livros didáticos e do recurso da "Roda dos Alimentos”, um círculo dividido em três partes e cada uma preenchida por fotos de alimentos construtores, energéticos e reguladores que convém ser ingeridos? Como conseguir que as importantes orientações da "Pirâmide Alimentar” cheguem aos alunos, incentivando-os a colocarem-nas em prática? A "Pirâmide” estabelece porções de alimentos de cada grupo que convém ser ingeridas para uma nutrição diária adequada para a saúde.

É preciso envolver os alunos ao estudar alimentação e nutrição, discutindo seus próprios hábitos de consumo, para que se conscientizem que os temas "nutrição e 
alimentação estão intrinsicamente ligados à saúde, bem estar e boa aparência”; “os alunos só aceitam o que reconhecem ser útil a si próprios” (Pipitone et al, 2004 - p. 12 e 15).

É importante fazê-los perceber que a expansão dos pontos de fast food é “capaz de introduzir novos hábitos de consumo, fazendo o indivíduo sonhar, imaginar e agir concretamente, sem perceber que vai sendo conquistado com sutileza. A publicidade faz tudo parecer normal, livre e somente através de profundo trabalho de observação, podemos perceber e avaliar o grau dessa manipulação do cotidiano, via consumo” (Ortigoza, 1997 - p. 23).

O professor deve discutir com os alunos o que a mídia veicula, deve procurar saber além das necessidades, os interesses de aprendizagem dos alunos.

"Estas recomendações podem ser auxiliares na construção de um modelo de ensino e aprendizagem em educação nutricional, no qual o professor atue como agente facilitador do processo capaz de selecionar atividades compatíveis com o desenvolvimento dos alunos e capazes de levá-los ao acesso das informações necessárias à concepção da nutrição/alimentação como um processo científico, intrinsicamente ligado às condições de saúde, tanto no âmbito individual como no âmbito da coletividade" (Pipitone et al, 2004 - p. 14).

Vê-se nos mais diferentes setores da sociedade uma dicotomia muito grande entre a teoria e a prática. Com a Educação Alimentar e Nutricional, que pode ser trabalhada no tema transversal Saúde assim como em Trabalho e Consumo, não tem sido diferente.

A fome existe por falta de nutrientes mínimos necessários para a sustentação do corpo; é fome celular e muito diferente da vontade de comer que uma pessoa experimenta, ao sentir o cheiro agradável de uma preparação culinária (Nidelcoff, 1970).

Ao se tratar da educação nutricional, vê-se nos livros didáticos “forte ênfase no aspecto biológico, negligenciando outros fatores que interferem no padrão de consumo alimentar dos escolares”... “se o viés biológico fosse decisivo, seria um sucesso o modelo de prescrição de dietas ideais ou a apresentação de modelos de uma alimentação equilibrada à criança e ao 
jovem. Se conhecer as funções dos grupos de alimentos no organismo humano fosse suficiente, as crianças estariam conseqüentemente rejeitando os junk foods” (Pipitone et al, 2004 - p. 9).

Em se tratando do assunto alimentação/ nutrição é importante se considerar que ocorre grande desperdício no Brasil; muito se produz, mas muito se perde no transporte, na conservação, no empacotamento e na estocagem da produção. E a população vem crescendo continuamente, sendo que grande parte do povo não tem renda mínima necessária para sustentar-se.

Além disso, a família brasileira passou por grandes transformações. Hoje, mesmo as que têm condições financeiras razoáveis, nem sempre têm conhecimentos suficientes ou tempo para dar orientação alimentar aos filhos. É comum prenderem-se a aspectos quantitativos dos alimentos, sem analisar, entretanto, a sua qualidade. Por outro lado pode ocorrer o contrário: estar preocupados com a qualidade dos alimentos, esquecendose dos aspectos quantitativos, ingerindo-os em excesso. Faltam-lhes informações sobre o quê, quando e quanto é melhor ingerir; tem havido uso indevido de certos alimentos em detrimento de outros.

É importante que haja adesão a hábitos alimentares mais saudáveis; as pesquisas sobre o padrão alimentar do brasileiro, como as de orçamento familiar feitas pelo IBGE, já apontam resultados que sugerem indicativos para a educação nutricional e alimentar.

A modernidade caracteriza-se por oferecer um ambiente social em que o indivíduo encontra condições de forjar um sistema de referências que mescla as influências familiares, escolares e midiáticas (entre outras), um sistema de esquemas coerente, no entanto híbrido e fragmentado (Setton, 2002).

Cabe à escola dar formação integral às crianças e jovens, cuja educação lhe são confiadas.

A educação para o consumo consciente de alimentos, pode hoje ser desenvolvida como elemento sócio-cultural de extrema importância numa sociedade onde os apelos do consumo incitam, de modo especial, o jovem e a criança ao consumo irrefletido. $\mathrm{O}$ aluno pode se instrumentalizar de informações e adquirir uma postura crítica em face das 
mensagens veiculadas pelos meios de comunicação que representam, em última análise, a marca da civilização atual (Pipitone \& Sturion, 1992 ).

A escola é o espaço ideal para o desenvolvimento de conhecimentos, atitudes e habilidades.

Há uma intensa necessidade de se providenciar, cada vez mais, uma educação nutricional de melhor qualidade aos cidadãos de todas as idades e em qualquer tipo de ocupação (De Angelis, 1999).

Contudo, acima de tudo, é preciso considerar que quando se decide trabalhar com educação, assume-se a complexidade que lhe é inerente, pois muitos fatores interferem nela; o aluno deve ser orientado para saber maximizar o aproveitamento dos recursos de que dispõe e associar a isso a busca da sua melhor qualidade de vida. 


\section{MATERIAL E MÉTODOS}

\subsection{Caracterização dos sujeitos de pesquisa}

Piracicaba é um município distante 160 Km da capital de São Paulo com 329.158 habitantes (IBGE, 2000), com estimativa de 344.698 (IBGE, 2003).

Analisou-se o consumo de alimentos e opiniões de, pelo menos, 20\% dos alunos concluintes do ensino fundamental da rede pública estadual e particular do município, em conjunto e separadamente, por modalidade de curso que freqüentam, período de funcionamento e localização da escola. (Quadros 1 e 2).

\subsubsection{Faixa Etária}

Entre os alunos da rede regular de ensino nas categorias A, B e C (escolas públicas) e $\alpha, \beta, \gamma$ (escolas particulares) de período diurno e noturno, de zona urbana e rural, a faixa etária predominante é de 14 e 15 anos, tanto na população masculina (91,24\%) como na feminina (90,91\%). (Quadro 3).

Entre os da rede de educação supletiva, a maior concentração está entre menores de 20 e até 29 anos na população masculina (82,76\%) e entre menores de 20 e 39 anos na população feminina (81,02\%). (Quadro 4).

\subsubsection{Peso}

Quanto ao peso, entre a população masculina da rede regular de ensino A, B e C (públicas) e $\alpha, \beta, \chi$ (particulares), incluindo período diurno e noturno, a maior concentração está entre 50 e $69 \mathrm{Kg}(57,5 \%)$ na população masculina e, na população feminina, entre 40 e 59 Kg (75,96\%). (Quadro 3). 
Entre os da Educação Supletiva a maior concentração na população masculina está entre 60 e 79 Kg (67,24\%) e na feminina entre 50 e 69 Kg (63,24\%). (Quadro4).

\subsubsection{Altura}

Quanto a altura, na população masculina da rede regular de ensino A, B e C incluindo período diurno e noturno em escolas da rede pública e particular, estas chamadas $\alpha, \beta, \chi$, a maior concentração está entre 1,60m e 1,79m na população masculina (70,27\%) e na feminina entre 1,59m e 1,69m (77,6\%). (Quadro 3).

Na população masculina da Educação Supletiva, 65,52\% têm altura entre 1,60m e 1,89m e na população feminina 70,59\% a têm menos de 1,59m a 1,69m. (Quadro 4).

\subsection{Base de Dados}

Adotou-se como base de dados, as informações obtidas junto a Diretoria Regional de Ensino de Piracicaba e escolas da rede particular de ensino fundamental.

De 5006 alunos existentes nas oitavas séries em escolas públicas estaduais (EPU) de zona urbana, 464 de zona rural e 956 em escolas particulares (EPA), coletou-se amostras estratificadas de, pelo menos, $20 \%$ por modalidade de curso e horário de funcionamento de cada categoria de escolas, considerando-se também o fato das mesmas estarem situadas em zona urbana ou rural. (Quadro 1).

\subsection{Coleta de dados}

Para a etapa de coleta de dados foi elaborado um questionário com doze questões objetivas e duas dissertativas, além do pedido de informação de idade, sexo, peso e altura do aluno colaborador (modelo anexo); com a devida autorização do diretor de cada unidade, do diretor regional de ensino e certificação do Comitê de Ética em Pesquisa nos termos da Resolução 196/1966 do Ministério da Saúde, os questionários foram aplicados nos concluintes do ensino fundamental de escolas pré-selecionadas quanto a localização e horário de funcionamento, para atender às necessidades da estratificação planejada, quanto ao número de alunos sujeitos da pesquisa. 


\subsection{Agrupamento de dados}

Para favorecer a comparação de dados em quadros e tabelas, separou-se as escolas de zona urbana em categorias: A, B , C (escolas públicas estaduais) e $\alpha, \beta, \gamma$ (escolas particulares).

A-Escolas Públicas Estaduais (EPU “A”) - localizadas num raio de até 1,5 Km do centro da cidade e Escolas Particulares (EPA “ $\alpha$ ”) com mensalidades superiores a dois salários mínimos.

B-Escolas Públicas Estaduais (EPU “B”) - localizadas num raio entre 1,5 Km e 2,5 Km do centro da cidade e Escolas Particulares (EPA “ $\beta$ ”) com um preço intermediário nas mensalidades, de 1,5 a 2 salários mínimos.

C-Escolas Públicas Estaduais (EPU “C”) - localizadas nos bairros mais periféricos e Escolas Particulares (EPA “ $\chi$ ”) cujas mensalidades têm valor mais accessível, até 1,5 salário mínimo.

A letra S - é acrescentada para designar Escolas Públicas Estaduais de Educação Supletiva (EPU “S”); se de categoria A - EPUA “S”; se de categoria B-EPUB "S”; se de categoria C-EPUC “S”. Não há escolas que cumprem a função suplência na rede particular de ensino.

A letra N - é acrescentada para designar escolas públicas estaduais que funcionam em período noturno (EPU “N”); se de categoria A-EPUA “N”; se de categoria B-EPUB “N”; se categoria C- EPUC “N”. Não há ensino fundamental noturno em escolas da rede particular de ensino.

Diante do exposto, ao se comentar sobre escolas de educação supletiva ou de ensino regular noturno, sempre se terá como referência as escolas públicas estaduais.

Quanto a escolas rurais (EPU “R”) não foram estratificadas quanto a localização; só existem em período diurno e na rede pública estadual de ensino. 
Quanto à modalidade de cursos de ensino fundamental, considerou-se:

Ensino Regular: quando os alunos que os freqüentam estão dentro de uma faixa etária normal, 14 anos de idade no caso da $8^{\mathrm{a}}$ série do período diurno, podendo haver pequenas variações, para mais ou para menos; em classes do período noturno essa idade chega a estender-se aos 18 anos; mesmo tendo idade que lhes dê direito a matricular-se na educação supletiva, muitas vezes os alunos preferem freqüentar a rede regular pela proximidade da escola de suas residências; ir a um estabelecimento mais distante pode significar mais despesa, menos tempo para dormir, mais obstáculos a vencer.

Educação Supletiva - modalidade Suplência, isto é, que supre a escolarização regular, freqüentado por alunos que não tiveram oportunidade de estudar ou de concluir seus estudos em idade apropriada e que retornam, já adultos, aos bancos escolares com pelo menos, 15 anos e 6 meses, mínimo exigido para matrícula na última série do ensino fundamental.

Quanto aos horários de funcionamento, considerou-se período diurno quando o curso se encerra até às 18 horas e noturno quando funciona a partir das 19 horas; não se trabalhou em escolas que eventualmente possam estar funcionando em período vespertino, abrangendo parte das aulas em período diurno e parte no noturno.

Quanto ao horário das refeições principais, considerou-se o café da manhã entre 6 e 8 horas, o almoço entre 11 e 13 horas e o jantar entre 18 e 20 horas.

É interessante se considerar que as escolas públicas mantém o Serviço de Merenda Escolar e que muitos alunos tem ali, gratuitamente, sua principal refeição, em função do horário que freqüentam as aulas e/ou, muito provavelmente, em função de sua situação sócio-enonômica.

\subsection{Software utilizado}

Confeccionou-se quadros, gráficos e tabelas para análise dos resultados, utilizando-se do software EXCEL ( 2000 ). 


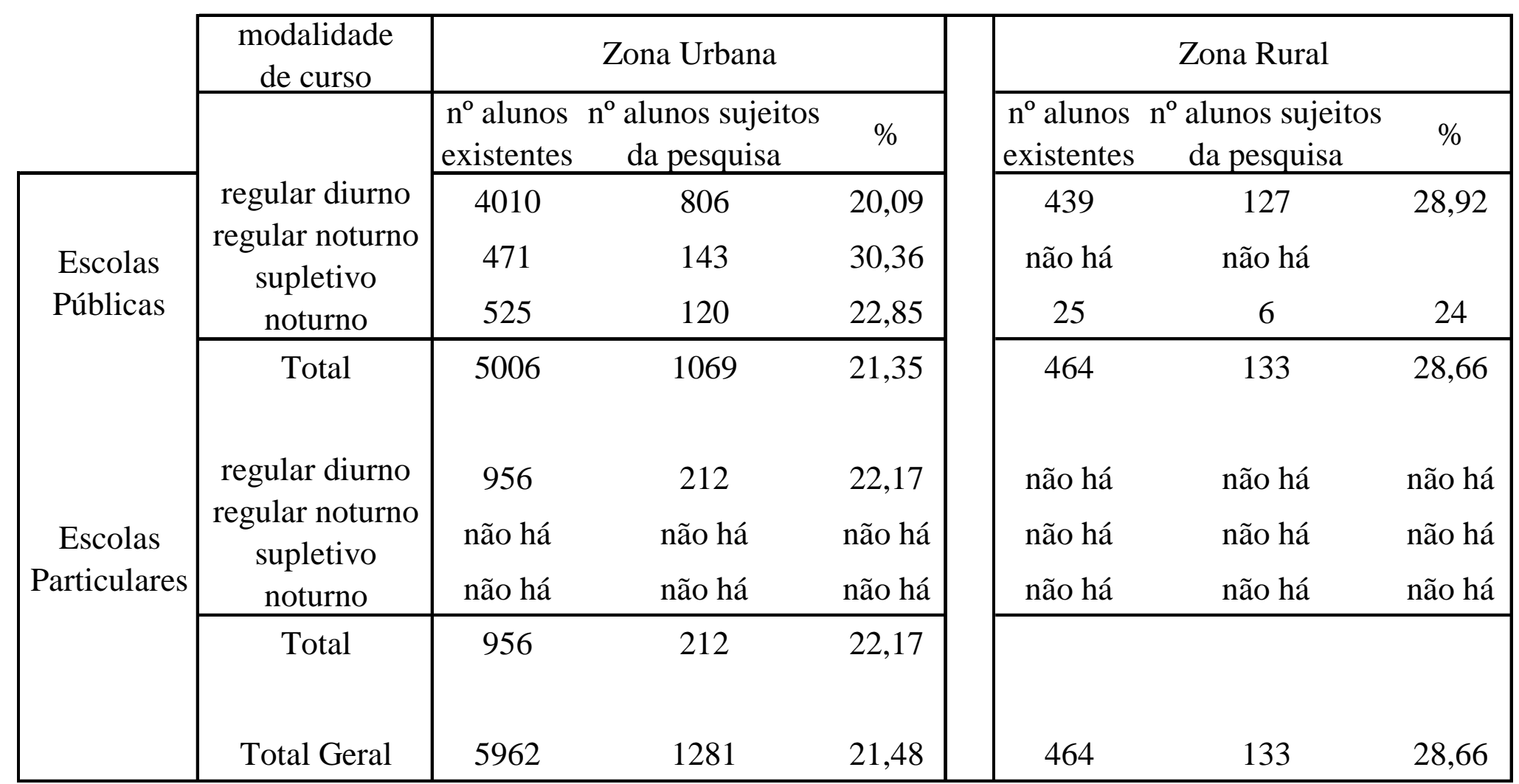

Quadro 1 Alunos existentes nas $8^{\mathrm{a}^{\mathrm{s}}}$ séries do Ensino Fundamental e sujeitos de pesquisa

Piracicaba (SP), 2004 


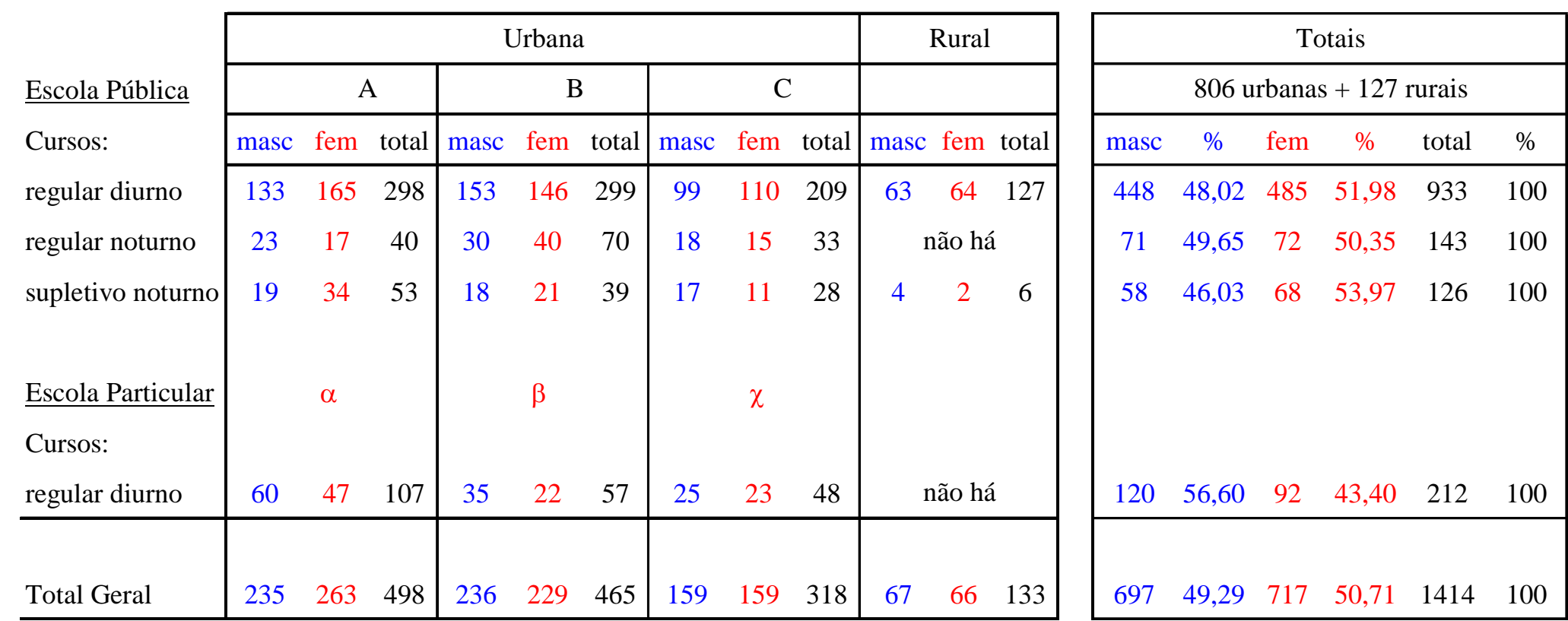

Quadro 2 Número de sujeitos da pesquisa por zona, tipo e categoria de escolas, modalidades de curso e períodos de funcionamento Piracicaba (SP), 2004 


\begin{tabular}{|c|c|c|c|c|c|c|c|c|c|c|c|c|c|c|c|c|c|c|}
\hline \multirow[b]{2}{*}{ Idades } & \multicolumn{2}{|c|}{ EPU "A" } & \multicolumn{2}{|c|}{ EPA " $\alpha "$} & \multicolumn{2}{|c|}{ EPU "B" } & \multicolumn{2}{|c|}{ ЕРA " $\beta "$} & \multicolumn{2}{|c|}{ CPU "C" } & \multicolumn{2}{|c|}{ EPA " $\chi "$} & \multicolumn{2}{|c|}{ EPU "R" } & \multicolumn{2}{|c|}{ EPU "N" } & \multicolumn{2}{|c|}{ Total Geral } \\
\hline & M & $\mathbf{F}$ & M & $\mathbf{F}$ & $\mathbf{M}$ & F & M & F & M & $\mathbf{F}$ & $\mathbf{M}$ & $\mathbf{F}$ & M & $\mathbf{F}$ & $\mathbf{M}$ & $\mathbf{F}$ & $\mathbf{M}$ & F \\
\hline 13 & 0 & 0 & 1 & 2 & 0 & 0 & 1 & 0 & 0 & 1 & 0 & 0 & 0 & 0 & 0 & 0 & 2 & 3 \\
\hline 14 & 84 & 85 & 45 & 38 & 112 & 100 & 21 & 16 & 48 & 68 & 19 & 12 & 36 & 42 & 30 & 31 & 395 & 392 \\
\hline 15 & 40 & 49 & 13 & 7 & 33 & 44 & 11 & 4 & 34 & 32 & 5 & 11 & 23 & 17 & 29 & 34 & 188 & 198 \\
\hline 16 & 5 & 27 & 1 & 0 & 7 & 2 & 1 & 1 & 11 & 6 & 1 & 0 & 4 & 3 & 5 & 7 & 35 & 46 \\
\hline 17 & 0 & 3 & 0 & 0 & 0 & 0 & 0 & 0 & 3 & 1 & 0 & 0 & 0 & 2 & 5 & 0 & 8 & 6 \\
\hline 18 & 3 & 0 & 0 & 0 & 0 & 0 & 0 & 0 & 3 & 2 & 0 & 0 & 0 & 0 & 1 & 0 & 7 & 2 \\
\hline em branco & 1 & 1 & 0 & 0 & 1 & 0 & 1 & 1 & 0 & 0 & 0 & 0 & 0 & 0 & 1 & 0 & 4 & 2 \\
\hline Total & 133 & 165 & 60 & 47 & 153 & 146 & 35 & 22 & 99 & 110 & 25 & 23 & 63 & 64 & 71 & 72 & 639 & 649 \\
\hline
\end{tabular}

\begin{tabular}{|c|c|c|c|c|c|c|c|c|c|c|c|c|c|c|c|c|c|c|}
\hline Peso & & & & & & & & & & & & & & & & & & \\
\hline até 30 & 0 & 0 & 0 & 2 & 0 & 0 & 0 & 0 & 0 & 0 & 0 & 0 & 0 & 0 & 0 & 0 & 0 & 2 \\
\hline $30 / 39$ & 7 & 14 & 4 & 16 & 7 & 4 & 0 & 0 & 1 & 2 & 1 & 2 & 2 & 0 & 3 & 1 & 25 & 39 \\
\hline $40 / 49$ & 17 & 65 & 19 & 23 & 30 & 55 & 0 & 3 & 17 & 37 & 1 & 8 & 16 & 37 & 14 & 26 & 114 & 254 \\
\hline $50 / 59$ & 43 & 58 & 24 & 2 & 46 & 61 & 7 & 9 & 29 & 52 & 10 & 10 & 19 & 17 & 27 & 30 & 205 & 239 \\
\hline $60 / 69$ & 26 & 12 & 8 & 1 & 39 & 19 & 13 & 1 & 34 & 8 & 5 & 2 & 16 & 8 & 22 & 8 & 163 & 59 \\
\hline $70 / 79$ & 12 & 5 & 0 & 1 & 16 & 4 & 4 & 2 & 9 & 7 & 4 & 0 & 5 & 1 & 1 & 2 & 51 & 21 \\
\hline 80 ou + & 13 & 6 & 1 & 0 & 14 & 0 & 7 & 0 & 3 & 1 & 4 & 1 & 4 & 0 & 1 & 1 & 47 & 9 \\
\hline em branco & 15 & 5 & 4 & 2 & 1 & 3 & 4 & 7 & 6 & 3 & 0 & 0 & 1 & 1 & 3 & 4 & 34 & 25 \\
\hline Total & $\mathbf{1 3 3}$ & $\mathbf{1 6 5}$ & $\mathbf{6 0}$ & $\mathbf{4 7}$ & $\mathbf{1 5 3}$ & $\mathbf{1 4 6}$ & $\mathbf{3 5}$ & $\mathbf{2 2}$ & $\mathbf{9 9}$ & $\mathbf{1 1 0}$ & $\mathbf{2 5}$ & $\mathbf{2 3}$ & $\mathbf{6 3}$ & $\mathbf{6 4}$ & $\mathbf{7 1}$ & $\mathbf{7 2}$ & $\mathbf{6 3 9}$ & $\mathbf{6 4 9}$ \\
\hline
\end{tabular}

\begin{tabular}{|c|c|c|c|c|c|c|c|c|c|c|c|c|c|c|c|c|c|c|}
\hline Altura & & & & & & & & & & & & & & & & & & \\
\hline até $1,59 \mathrm{~m}$ & 14 & 44 & 1 & 13 & 16 & 33 & 3 & 3 & 10 & 24 & 4 & 9 & 8 & 16 & 13 & 24 & 69 & 166 \\
\hline $1,60 / 69$ & 44 & 79 & 15 & 28 & 46 & 75 & 6 & 16 & 28 & 70 & 4 & 10 & 20 & 34 & 19 & 26 & 182 & 338 \\
\hline $1,70 / 79$ & 46 & 32 & 36 & 5 & 65 & 24 & 16 & 3 & 41 & 10 & 10 & 4 & 26 & 10 & 27 & 13 & 267 & 101 \\
\hline $1,80 / 89$ & 17 & 1 & 5 & 0 & 17 & 3 & 8 & 0 & 13 & 1 & 5 & 0 & 6 & 1 & 7 & 0 & 78 & 6 \\
\hline em branco & 12 & 9 & 3 & 1 & 9 & 11 & 2 & 0 & 7 & 5 & 2 & 0 & 3 & 3 & 5 & 9 & 43 & 38 \\
\hline Total & $\mathbf{1 3 3}$ & $\mathbf{1 6 5}$ & $\mathbf{6 0}$ & $\mathbf{4 7}$ & $\mathbf{1 5 3}$ & $\mathbf{1 4 6}$ & $\mathbf{3 5}$ & $\mathbf{2 2}$ & $\mathbf{9 9}$ & $\mathbf{1 1 0}$ & $\mathbf{2 5}$ & $\mathbf{2 3}$ & $\mathbf{6 3}$ & $\mathbf{6 4}$ & $\mathbf{7 1}$ & $\mathbf{7 2}$ & $\mathbf{6 3 9}$ & $\mathbf{6 4 9}$ \\
\hline
\end{tabular}

\begin{tabular}{|c|c|c|c|c|c|c|c|c|c|c|c|c|c|c|c|c|c|c|}
\hline $\begin{array}{c}\text { Total } \\
\text { Alunos }\end{array}$ & 133 & 165 & 60 & 47 & 153 & 146 & 35 & 22 & 99 & 110 & 25 & 23 & 63 & 64 & 71 & 72 & $\mathbf{6 3 9}$ & $\mathbf{6 4 9}$ \\
\hline
\end{tabular}

EPU "A" Escolas Públicas Categoria A Diurno EPA " $\alpha$ " Escolas Particulares Categoria $\alpha$ Diurno EPU "B" Escolas Públicas Categoria B Diurno EPA " $\beta$ " Escolas Particulares Categoria $\beta$ Diurno EPU "N" Escolas Públicas Noturno
EPU "C" Escolas Públicas Categoria C Diurno EPA " $\chi$ " Escolas Particulares Categoria $\chi$ Diurno EPU "R" Escolas Públicas Rurais Diurno

Quadro 3 Distribuição dos sujeitos de pesquisa do ensino regular por idade, peso, altura, sexo e categoria de escolas Piracicaba (SP), 2004 


\begin{tabular}{|c|c|c|c|c|c|c|c|c|c|c|}
\cline { 2 - 12 } \multicolumn{1}{c|}{} & \multicolumn{2}{c|}{ EPUS "A" } & \multicolumn{2}{c|}{ EPUS "B" } & \multicolumn{2}{c|}{ EPUS "C" } & \multicolumn{2}{c|}{ EPUS "R" } & \multicolumn{2}{c|}{ Total Geral } \\
\hline Idades & $\mathbf{M}$ & $\mathbf{F}$ & $\mathbf{M}$ & $\mathbf{F}$ & $\mathbf{M}$ & $\mathbf{F}$ & $\mathbf{M}$ & $\mathbf{F}$ & $\mathbf{M}$ & $\mathbf{F}$ \\
\hline até 19 & 8 & 7 & 9 & 6 & 6 & 2 & 4 & 0 & 27 & 15 \\
\hline 20 a 29 & 7 & 10 & 8 & 5 & 6 & 1 & 0 & 2 & 21 & 18 \\
\hline 30 a 39 & 3 & 13 & 1 & 2 & 3 & 7 & 0 & 0 & 7 & 22 \\
\hline 40 a 49 & 0 & 2 & 0 & 8 & 2 & 1 & 0 & 0 & 2 & 11 \\
\hline 20 a 59 & 0 & 2 & 0 & 0 & 0 & 0 & 0 & 0 & 0 & 2 \\
\hline 60 ou + & 0 & 0 & 0 & 0 & 0 & 0 & 0 & 0 & 0 & 0 \\
\hline em branco & 1 & 0 & 0 & 0 & 0 & 0 & 0 & 0 & 1 & 0 \\
\hline Total & $\mathbf{1 9}$ & $\mathbf{3 4}$ & $\mathbf{1 8}$ & $\mathbf{2 1}$ & $\mathbf{1 7}$ & $\mathbf{1 1}$ & $\mathbf{4}$ & $\mathbf{2}$ & $\mathbf{5 8}$ & $\mathbf{6 8}$ \\
\hline
\end{tabular}

\begin{tabular}{|c|c|c|c|c|c|c|c|c|c|c|}
\hline Peso & & & & & & & & & & \\
\hline até 30 & 0 & 0 & 0 & 0 & 0 & 0 & 0 & 0 & 0 & 0 \\
\hline $30 / 39$ & 0 & 0 & 0 & 0 & 0 & 0 & 0 & 0 & 0 & 0 \\
\hline $40 / 49$ & 1 & 4 & 0 & 2 & 0 & 0 & 2 & 1 & 3 & 7 \\
\hline $50 / 59$ & 0 & 11 & 3 & 7 & 5 & 0 & 2 & 1 & 10 & 19 \\
\hline $60 / 69$ & 12 & 11 & 7 & 5 & 5 & 4 & 0 & 0 & 24 & 20 \\
\hline $70 / 79$ & 4 & 4 & 5 & 0 & 6 & 1 & 0 & 0 & 15 & 5 \\
\hline 80 ou + & 2 & 2 & 2 & 5 & 1 & 2 & 0 & 0 & 5 & 9 \\
\hline em branco & 0 & 2 & 1 & 2 & 0 & 0 & 0 & 0 & 1 & 4 \\
\hline Total & $\mathbf{1 9}$ & 34 & $\mathbf{1 8}$ & $\mathbf{2 1}$ & $\mathbf{1 7}$ & $\mathbf{7}$ & $\mathbf{4}$ & $\mathbf{2}$ & $\mathbf{5 8}$ & $\mathbf{6 4}$ \\
\hline
\end{tabular}

\begin{tabular}{|}
\begin{tabular}{|c|c|c|c|c|c|c|c|c|c|c|}
\hline Altura & & & & & & & & & & \\
\hline até $1,59 \mathrm{~m}$ & 0 & 7 & 1 & 6 & 0 & 1 & 1 & 0 & 2 & 14 \\
\hline $1,60 / 69$ & 4 & 15 & 2 & 10 & 5 & 8 & 3 & 1 & 14 & 34 \\
\hline $1,70 / 79$ & 11 & 5 & 7 & 2 & 8 & 1 & 0 & 0 & 26 & 8 \\
\hline $1,80 / 89$ & 4 & 0 & 6 & 0 & 2 & 0 & 0 & 1 & 12 & 1 \\
\hline em branco & 0 & 7 & 2 & 3 & 2 & 1 & 0 & 0 & 4 & 11 \\
\hline Total & $\mathbf{1 9}$ & 34 & $\mathbf{1 8}$ & $\mathbf{2 1}$ & $\mathbf{1 7}$ & $\mathbf{1 1}$ & $\mathbf{4}$ & $\mathbf{2}$ & $\mathbf{5 8}$ & $\mathbf{6 8}$ \\
\hline $\begin{array}{c}\text { Total } \\
\text { Alunos }\end{array}$ & 19 & 34 & 18 & 21 & 17 & 11 & 4 & 2 & $\mathbf{5 8}$ & $\mathbf{6 8}$ \\
\hline
\end{tabular} \\
\hline
\end{tabular}

EPUS "A" Escolas Públicas de educação supletiva Categoria A urbana EPUS "B" Escolas Públicas de educação supletiva Categoria B urbana EPUS "C" Escolas Públicas de educação supletiva Categoria C urbana EPUS "R" Escolas Públicas de educação supletiva Categoria Rural

Quadro 4 Distribuição dos sujeitos de pesquisa da educação supletiva por idade, peso, altura, sexo e categoria de escolas Piracicaba (SP), 2004 


\section{RESULTADOS E DISCUSSÃO}

Após a compilação dos dados elaborou-se tabelas, quadros e gráficos para observação de aspectos quantitativos e qualitativos do consumo de alimentos pelos concluintes do ensino fundamental.

Muitos estudos futuros podem ser feitos sendo analisados os dados coletados. Os hábitos alimentares diferem entre estudantes de escolas de categorias diferentes? Em que diferem? O quanto diferem? Dentro de uma mesma categoria de escolas, os hábitos na seleção de alimentos a ingerir são os mesmos entre estudantes de escolas públicas e particulares? Quais são as semelhanças e/ou diferenças no comportamento de consumo entre estudantes de zona urbana e rural? Em que diferem os hábitos de consumo entre alunos da rede regular de ensino e da educação supletiva? Os alunos do período diurno têm os mesmos hábitos alimentares dos alunos do período noturno? Em que aspectos são observadas semelhanças / diferenças? A população feminina tem os mesmos hábitos na seleção de alimentos que a população masculina? Pode-se estabelecer comparações em muitos aspectos. Expõe-se em seguida, algumas constatações entre tantas outras possíveis.

\subsection{Análise da Seleção de Alimentos}

\subsubsection{Quanto ao Café da Manhã}

A partir da análise das tabelas 1, 1A, 1B, 1C, dos Quadros 5 e 6 e das Figuras 1 e 2 observa-se: 


\subsubsection{Comparando-se zona urbana e rural:}

- que parte considerável de nossos alunos têm o hábito de não tomar o café da manhã.

zona urbana: EPU: 27,54\% da rede regular do diurno, 8,39\% da rede regular do noturno e 23,33\% da educação supletiva ; EPA: 20,75\%

zona rural: 9,45\% (Quadro 5).

- que, em linhas gerais, considerando-se tanto escolas públicas quanto particulares, da educação regular e supletiva, em diferentes horários de funcionamento, 79,84\% dos alunos do sexo masculino têm o hábito de tomá-lo enquanto o fazem apenas 72,96\% da população feminina da zona urbana; na zona rural tomam o café da manhã 88,06\% de estudantes do sexo masculino e 89,39\% do sexo feminino. (Quadro 5 ).

Na zona rural os concluintes do ensino fundamental são, pois, mais adeptos do hábito de tomar o café da manhã, seguidos pelos alunos da rede regular de ensino noturno em escolas públicas de zona urbana.

- que os cinco alimentos de maior consumo no café da manhã apontados pelos alunos tanto do sexo masculino como feminino, conforme Tabela 1 são:

\section{Zona Urbana}

$$
1^{\circ} \text { - Pão }
$$

$2^{\circ}$ - Leite

$(90,25 \%)$

$3^{\circ}$ - Café $\quad(73,58 \%)$

$4^{\circ}$ - Manteiga (63,09\%)

$5^{\circ}$ - Bolacha $\quad(50,37 \%)$
Zona Rural

$$
\begin{array}{ll}
1^{\circ}-\text { Pão } & (92,17 \%) \\
2^{\circ}-\text { Leite } & (86,09 \%) \\
3^{\circ} \text { - Bolacha } & (66,96 \%) \\
4^{\circ} \text { - Café } & (65,22 \%) \\
5^{\circ} \text { - Bolo } & (58,26 \%)
\end{array}
$$

O consumo de pão, leite, café e manteiga é maior na zona urbana; o de bolacha e bolo é maior na zona rural

\subsubsection{Comparando-se por período de funcionamento das escolas de zona urbana:-} que são mais adeptos do hábito, os alunos de escolas públicas de ensino regular noturno 
(91,61\%) que os do ensino regular diurno (72,83\% de escolas públicas e 79,25\% de escolas particulares).(Quadro 5).

\subsubsection{Comparando-se por modalidade de curso:}

- que os alunos da educação supletiva são menos adeptos do hábito (76,67\%) que os da rede regular de ensino $(91,61 \%)$, no mesmo horário de funcionamento da escola (noturno). (Quadro 5).

- que entre os alunos da rede regular de ensino, é maior o percentual de alunos que tomam o café da manhã entre os da rede particular (79,25\%) que os da rede pública (72,83\%). (Quadro 5).

\subsubsection{Comparando-se por sexo}

- que são maiores os percentuais de estudantes do sexo masculino que tomam o café da manhã, que os da população feminina na rede regular de ensino das escolas públicas do período diurno em zona urbana e rural. ( Quadro 5).

Urbana: $\quad 80,00 \%$ masculino e 65,36 feminino

Rural: $\quad 92,06 \%$ masculino e $89,06 \%$ feminino

- que, comparando-se com a população masculina, é maior o percentual da população feminina que toma o café da manhã, entre estudantes da educação supletiva de zona urbana e rural (noturno), da rede regular de ensino noturno e das escolas particulares de ensino regular (diurno) (Quadro 5).

Educação Supletiva zona urbana 72,22\% masculino e $80,30 \%$ feminino

Educação Supletiva zona rural $\quad 25,00 \%$ masculino e $100,00 \%$ feminino

Ensino regular noturno $\quad 90,14 \%$ masculino e 93,06\% feminino

Rede particular de ensino diurno $76,67 \%$ masculino e $82,61 \%$ feminino 


\subsubsection{Por categoria de escolas:}

- que, em se comparando os valores percentuais de alunos que tomam o café da manhã em escolas das categorias A, B e C urbanas observa-se no Quadro 6:

a) Na população masculina:

- nas escolas públicas da rede regular do diurno e também da educação supletiva de zona urbana, quanto mais periféricas as escolas, maior é o percentual de elementos do sexo masculino que tomam o café da manhã.

- escolas de categoria A 72,93\% na educação regular e 57,89\% na educação supletiva

categoria B 79,73\% na educação regular e 72,22\% na educação supletiva. categoria C 89,89\% na educação regular e 88,23\% na educação supletiva.

- no período noturno na rede regular de ensino, acontece exatamente o inverso: quanto mais central a escola, maior é o valor percentual entre estudantes do sexo masculino que tomam o café da manhã; nas escolas de categoria A 100\%, categoria B $90,00 \%$ e categoria C $77,77 \%$.

Cumpre observar que grande parte dos alunos da rede de ensino regular noturno e da educação supletiva que freqüentam as escolas de categoria A (centrais) pertencem às camadas mais pobres da população; são trabalhadores do comércio que, por residirem em bairros muito periféricos, costumam estudar no centro da cidade para pagar apenas uma condução para retornar às suas casas.

- nas escolas particulares, os que mais têm o hábito de tomar o café da manhã freqüentam escolas da categoria $\beta$ (80\%) e os que menos tomam são da categoria $\chi$ (68\%).

b) Na população feminina:

- nas escolas públicas da rede regular do diurno: 
- a população da zona rural é a que mais tem o hábito de tomar o café da manhã $(89,06 \%)$;

- as alunas da zona urbana, de escolas da categoria B são as que têm maior porcentagem do hábito (69,86\%), seguidas pelas de categoria C com 65,45\% e A com apenas 63,63\%;

- nas escolas públicas do período noturno, regular e de educação supletiva, quanto mais periférica a escola, maior é o número da população feminina em estudo que tem o hábito de tomar o café da manhã;

A $82,35 \%$ no regular e $76,47 \%$ na educação supletiva

B 95,00\% no regular e 80,95\% na educação supletiva

C 100,00\% no regular e 90,90\% na educação supletiva;

Vê-se ainda, comparando esses valores, que as escolares do sexo feminino da rede regular são mais adeptas do hábito de tomar o café da manhã que as da educação supletiva.

- nas escolas particulares de categoria $\alpha$ está o maior percentual de meninas que tomam o café da manhã (93,61\%), seguidas pelas de categoria $\chi$ com $82,60 \%$ e por último as de categoria $\beta$ com 59,09\%.

Observa-se que o percentual da categoria $\chi$ de escolas particulares (82,60\%) é bem próximo ao da categoria A de escolas públicas da rede regular do noturno $(82,35 \%)$.

c) no geral, em ambos os sexos, os maiores percentuais de alunos que têm o hábito de tomar o café da manhã estão entre os que freqüentam o curso regular noturno, tanto para escolas de categoria A, B e C, respectivamente 92,50\%, 92,85\% e 91,60\% .

Observando-se especificamente o hábito de beber café, nota-se que a ingestão é menor por estudantes das escolas de categoria A e $\alpha$, sendo $24,22 \%$ na população masculina e 26,99\% na feminina; na categoria B e $\beta$ os percentuais são de $64,21 \%$ na população masculina e 57,85\% na feminina; na categoria C e $\chi$ correspondem a 65,93\% 
na população masculina e 77,59\% na feminina (Tabelas 1A, 1B e 1C). Entre todos os alunos, é mais consumido por alunos da rede pública de educação supletiva e menos consumido pelos estudantes das escolas particulares (Figura 2).

Quanto ao leite, este é bebido em maior percentual pelos estudantes masculinos de zona rural (100\%) e pelos de escolas particulares (91,39\%); na população feminina é mais ingerido entre alunas da educação supletiva (84,90\%) e ensino regular noturno (74,62\%); as que menos consomem são alunas da rede particular de ensino (60,25\%). (Tabela 1). Considerando-se em linhas gerais, é muito bom o consumo de leite por alunos de todas as categorias de escolas, superior a 70,00\%, embora não tenhamos conhecimento das quantidades ingeridas (Figura 2).

O pão é menos ingerido pela população de ambos os sexos de escolas particulares (68,81\% sexo masculino e 60,25\% sexo feminino); é mais consumido pelo sexo masculino em zona rural $(98,28 \%)$ e pelo sexo feminino entre as alunas de escolas públicas do curso regular noturno (100,00\%) (Tabela 1). Considerando-se em linhas gerais, mais de 65\% dos alunos incluem pão no café da manhã em todas as categorias de escolas (Figura 2).

Chama atenção o consumo de bolo e bolachas, principalmente pela população masculina de escolas públicas de zona rural: 74,14\% e 77,59\% respectivamente. (Tabela1 e Figura 2). Nesta população 88,06\% dos alunos e 89,39\% das alunas têm o hábito de tomar o café da manhã.

Bolachas integram o café da manhã da população masculina e feminina de escolas públicas do ensino regular noturno, em percentuais consideráveis: 56,25\% e $56,71 \%$ respectivamente (Tabela 1 ).

Quanto ao consumo de frutas no café da manhã, só está entre as cinco primeiras escolhas entre as alunas da rede particular de ensino, na Categoria $\alpha$; nas escolas de categoria $\mathrm{A}, \mathrm{B}, \beta$ e $\chi$, as frutas não constam entre as cinco primeiras escolhas; na 
categoria C está entre as cinco primeiras apenas entre as alunas da educação supletiva. O consumo de frutas no café da manhã é pequeno (Figura 2).

Quanto ao consumo de sucos, apesar de não estar entre as bebidas mais escolhidas no café da manhã, nota-se preferência pelo suco natural ao artificial, na maioria dos grupos estudados; apenas nas escolas públicas de categoria A, a população masculina e feminina do curso regular noturno demonstra consumir percentuais significativos de suco artificial, assim como os alunos do gênero masculino da educação supletiva. Relembra-se que grande parte desses estudantes residem nos bairros mais periféricos da cidade, freqüentando escolas centrais por serem próximas dos locais onde trabalham.

Observa-se pequena variação nos alimentos consumidos no café da manhã entre alunos adolescentes das escolas particulares do diurno e entre alunos adultos da rede pública do ensino regular e de educação supletiva, ambos do noturno, pois estes últimos incluem queijo, requeijão, presunto, mortadela, bolo, ovos, frutas, o que acontece bem menos entre alunos do diurno. 


\begin{tabular}{|c|c|c|c|c|c|c|c|c|c|c|c|c|c|c|c|}
\hline & \multicolumn{15}{|c|}{ ZONA URBANA } \\
\hline & \multicolumn{3}{|c|}{ Sujeitos Existentes } & \multicolumn{6}{|c|}{ Tomam Café da Manhã } & \multicolumn{6}{|c|}{ Não tomam Café da Manhã } \\
\hline & \begin{tabular}{|c|} 
Total \\
masculino
\end{tabular} & \begin{tabular}{c|c|}
$\begin{array}{c}\text { Total } \\
\text { feminino }\end{array}$ \\
\end{tabular} & Total & MASC & $\%$ & FEM & $\%$ & TOTAL & $\%$ & MASC & $\%$ & FEM & $\%$ & TOTAL & $\%$ \\
\hline EPU regular diurno & 385 & 421 & 806 & 308 & 80 & 279 & 65,56 & 587 & 72,83 & 77 & 20 & 145 & 34,44 & 222 & 27,54 \\
\hline EPU regular noturno & 71 & 72 & 143 & 64 & 90,14 & 67 & 93,06 & 131 & 91,61 & 7 & 9,86 & 5 & 6,94 & 12 & 8,39 \\
\hline EPU suplência noturno & 54 & 66 & 120 & 39 & 72,22 & 53 & 80,30 & 92 & 76,67 & 15 & 27,78 & 13 & 19,70 & 28 & 23,33 \\
\hline EPA regular diurno & 120 & 92 & 212 & 92 & 76,67 & 76 & 82,61 & 168 & 79,25 & 28 & 23,33 & 16 & 17,39 & 44 & 20,75 \\
\hline Total & 630 & 651 & 1.281 & 503 & 79,84 & 475 & 72,96 & 978 & 76,35 & 127 & 18,33 & 179 & 25,72 & 306 & 22,03 \\
\hline \multicolumn{16}{|c|}{ ZONA RURAL } \\
\hline & \multicolumn{3}{|c|}{ Sujeitos Existentes } & \multicolumn{6}{|c|}{ Tomam Café da Manhã } & \multicolumn{6}{|c|}{ Não tomam Café da Manhã } \\
\hline & \begin{tabular}{|c} 
Total \\
masculino \\
\end{tabular} & \begin{tabular}{|c|}
$\begin{array}{c}\text { otatal } \\
\text { feminino }\end{array}$ \\
\end{tabular} & Total & MASC & $\%$ & FEM & $\%$ & TOTAL & $\%$ & MASC & $\%$ & FEM & $\%$ & TOTAL & $\%$ \\
\hline EPU regular diurno & 63 & 64 & 127 & 58 & 92,06 & 57 & 89,06 & 115 & 90,55 & 5 & 7,94 & 7 & 10,94 & 12 & 9,45 \\
\hline EPU suplência noturno & 4 & 2 & 6 & 1 & 25 & 2 & 100 & 3 & 50 & 3 & 75 & & & 3 & 50 \\
\hline Total & 67 & 66 & 133 & 59 & 88,06 & 59 & 89,39 & 118 & 88,72 & 8 & 11,94 & 7 & 10,61 & 15 & 11,28 \\
\hline
\end{tabular}

Quadro 5 Concluintes do ensino fundamental, de acordo com as citações relativas ao hábito de tomar o café da manhã Piracicaba (SP), 2004 


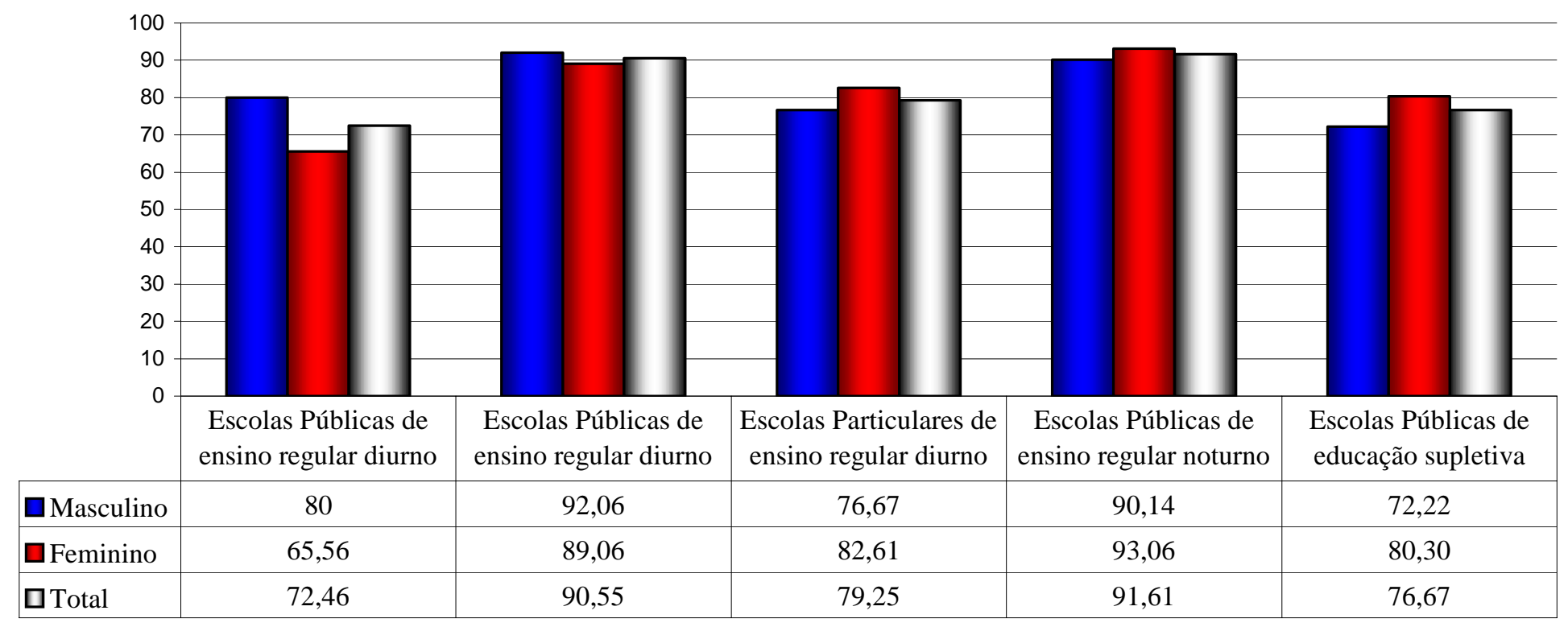

Figura 1 Alunos que têm o hábito de tomar café da manhã 


\begin{tabular}{|c|c|c|c|c|c|c|c|c|c|c|c|c|}
\hline Escolas Públicas & $\begin{array}{l}\text { A zona } \\
\text { urbana }\end{array}$ & $\begin{array}{l}\text { A zona } \\
\text { urbana }\end{array}$ & $\begin{array}{l}\text { A zona } \\
\text { urbana }\end{array}$ & $\begin{array}{l}\text { B zona } \\
\text { urbana }\end{array}$ & $\begin{array}{l}\text { B zona } \\
\text { urbana }\end{array}$ & $\begin{array}{l}\text { B zona } \\
\text { urbana }\end{array}$ & $\begin{array}{l}\text { C zona } \\
\text { urbana }\end{array}$ & $\begin{array}{l}\text { C zona } \\
\text { urbana }\end{array}$ & $\begin{array}{l}\text { C zona } \\
\text { urbana }\end{array}$ & Rural & Rural & Rural \\
\hline Cursos & Masculino & Feminino & Total & Masculino & Feminino & Total & Masculino & Feminino & Total & Masculino & Feminino & Total \\
\hline Regular diurno & $72,93 \%$ & $63,63 \%$ & $85,04 \%$ & $79,73 \%$ & $69,86 \%$ & $74,91 \%$ & $89,89 \%$ & $65,45 \%$ & $77,03 \%$ & $92,06 \%$ & $89,06 \%$ & $90,55 \%$ \\
\hline Regular noturno & $100 \%$ & $82,35 \%$ & $92,50 \%$ & $90 \%$ & $95 \%$ & $92,85 \%$ & $77,77 \%$ & $100 \%$ & $91,60 \%$ & Não há & Não há & Não há \\
\hline $\begin{array}{l}\text { Supletivo } \\
\text { noturno }\end{array}$ & $57,89 \%$ & $76,47 \%$ & $69,81 \%$ & $72,22 \%$ & $80,95 \%$ & $76,92 \%$ & $88,23 \%$ & $90,90 \%$ & $89,28 \%$ & $25 \%$ & $100 \%$ & $50 \%$ \\
\hline \begin{tabular}{|l} 
Escolas \\
Particulares
\end{tabular} & $\alpha$ & $\alpha$ & $\alpha$ & $\beta$ & $\beta$ & $\beta$ & $\chi$ & $\chi$ & $\chi$ & & & \\
\hline Regular diurno & $78,33 \%$ & $93,61 \%$ & $85,04 \%$ & $80 \%$ & $59,09 \%$ & $71,92 \%$ & $68 \%$ & $82,60 \%$ & $75 \%$ & Não há & Não há & Não há \\
\hline
\end{tabular}

OBS: analisar no sentido horizontal e vertical.

Quadro 6 Percentuais de alunos que têm o hábito de tomar o café da manhã diariamente, por categoria de escolas Piracicaba (SP), 2004 


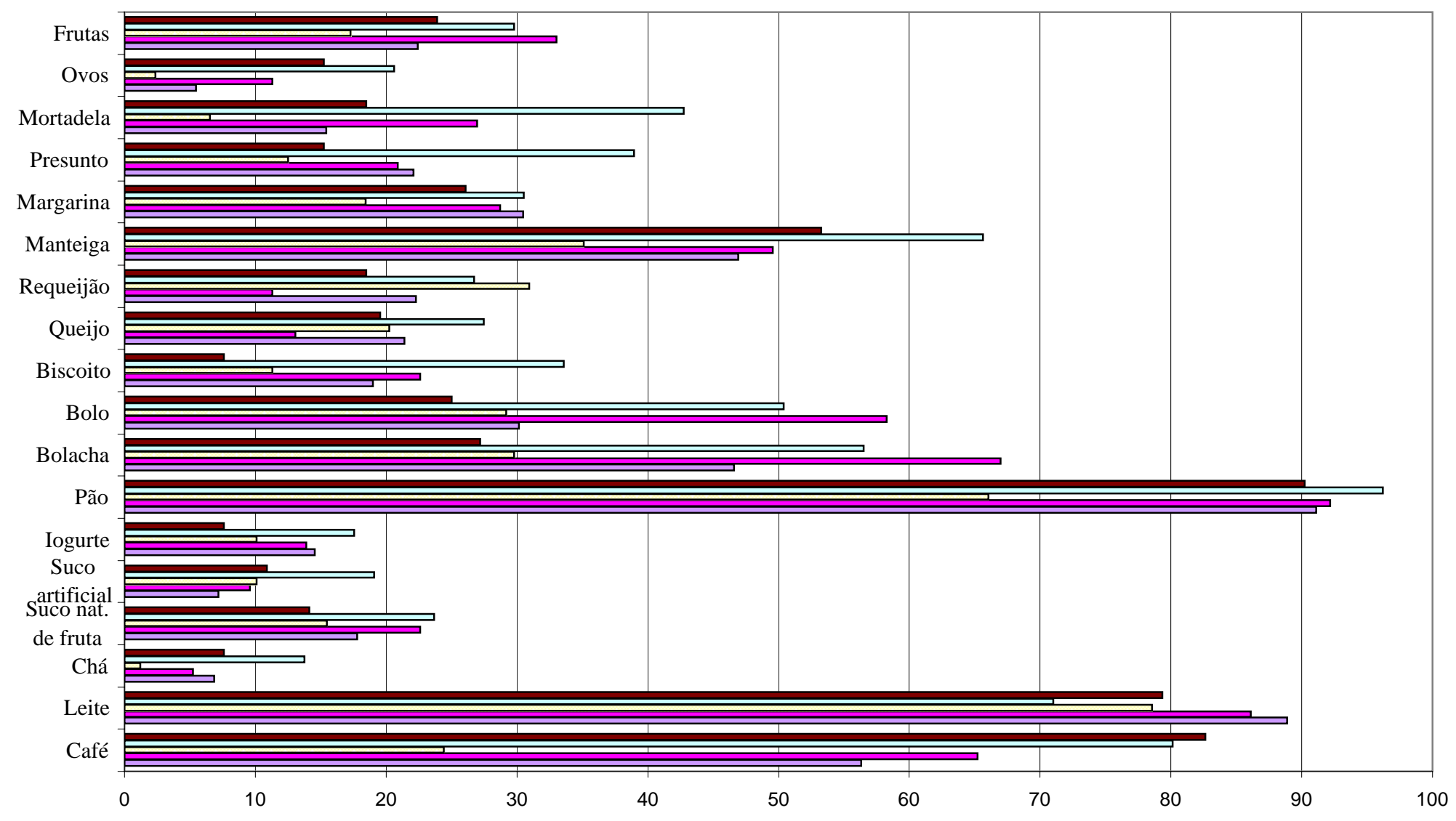

$\square$ Escolas Públicas de ensino regular diurno urbano

$\square$ Escolas Públicas de ensino regular diurno rural

$\square$ Escolas Particulares de ensino regular diurno urbano

$\square$ Escolas Públicas de ensino regular noturno urbano

—Escolas Públicas de educação supletiva noturno urbana

Figura 2 Alimentos ingeridos no café da manhã- Piracicaba(SP), 2004 
Tabela1. Comparativa entre alunos de escolas públicase particulares de zona urbana e rural, quanto aos alimentos selecionados pelos que tomam CAFÉ DA MANHÃ. Piracicaba (SP), 2004

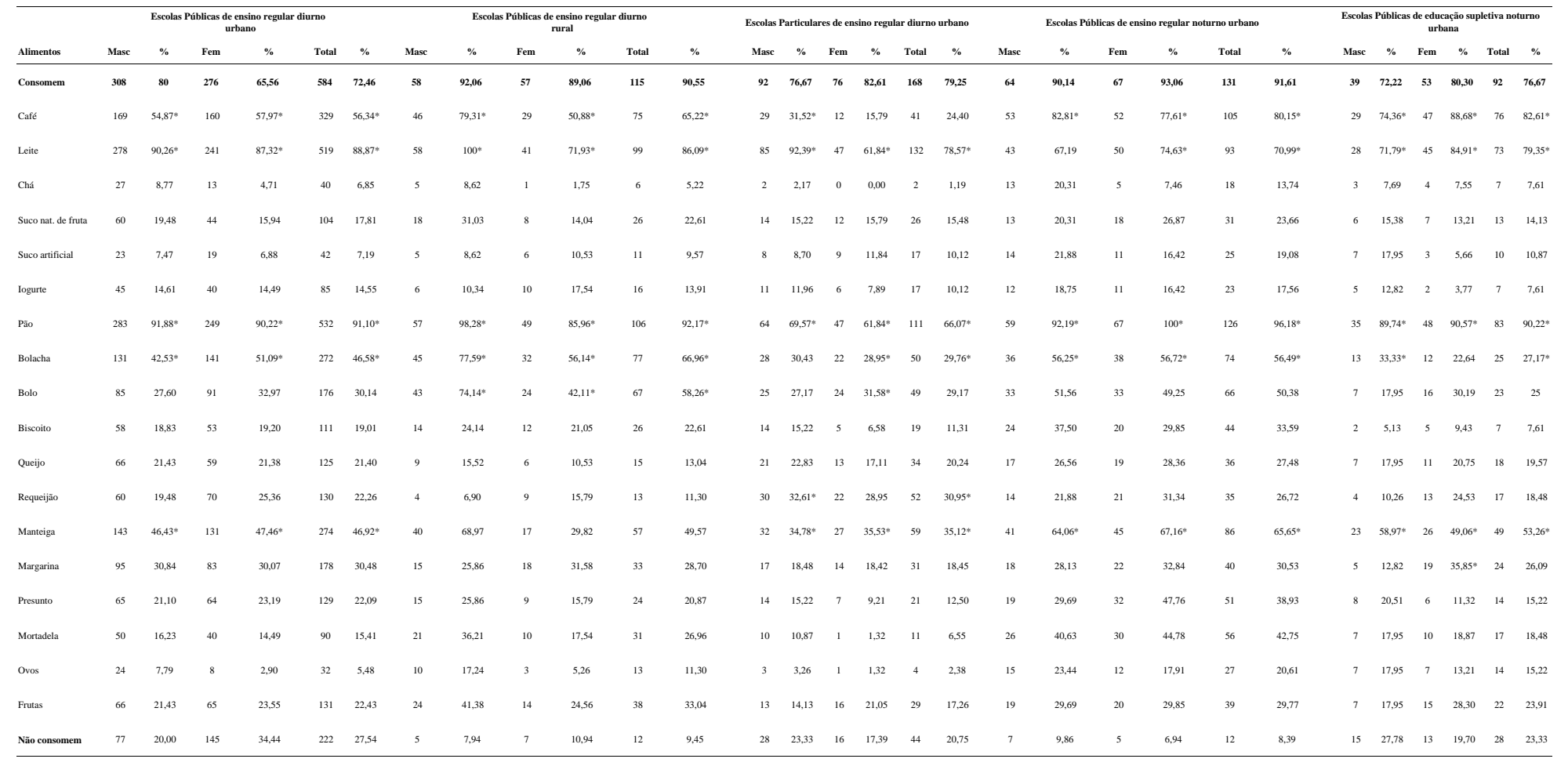


Tabela 1A. No de alunos que assinalaram cada alimento eas devidas porcentagens, referindo-se ao que ingerem no CAFÉ DA MANHÃ. Escolas Públicas de categoria Ae Particulares $\alpha$ (Zona
Urbana). Piracicabaa(SP), 2004

\begin{tabular}{|c|c|c|c|c|c|c|c|c|c|c|c|c|c|c|c|c|c|c|c|c|c|c|c|c|}
\hline \multirow[b]{2}{*}{ Alimentos } & \multicolumn{4}{|c|}{ EPU regular diurno } & \multicolumn{4}{|c|}{ EPU regular noturno } & \multicolumn{4}{|c|}{ EPU educasăoso supletiva } & \multicolumn{4}{|c|}{ Total Escolas Püblicas } & \multicolumn{4}{|c|}{ EPA regular diurno } & \multicolumn{4}{|c|}{ TOTAL GERAL } \\
\hline & $\underset{\text { masc Masc }}{97}$ & $\%$ & & $\%$ & $\begin{array}{l}23 \\
\text { masc Masc }\end{array}$ & $\%$ & $\underset{\substack{1+m \\
\text { Iem }}}{\mathrm{Fem}}$ & $\%$ & $\begin{array}{l}111 \\
\text { masc Masc }\end{array}$ & $\%$ & $\underset{\text { fem }}{26}$ Fem & $\%$ & $\underset{\text { masc Masc }}{131}$ & $\%$ & $\substack{\text { fem } \\
145} \mathrm{Fem}^{\mathrm{Fem}}$ & $\%$ & $\begin{array}{l}{ }_{\text {masc }}^{47} \text { Masc } \\
\text { Mast }\end{array}$ & $\%$ & $\underset{\mathrm{fem}}{44} \mathrm{Fem}$ & $\%$ & $\begin{array}{l}322 \\
\text { masc Masc } \\
\text { masc }\end{array}$ & $\%$ & $\underset{\mathrm{fem}}{352} \mathrm{Fem}$ & $\%$ \\
\hline Cafe & 43 & $44,33^{*}$ & 54 & $51,43^{*}$ & 19 & $82,61^{*}$ & 14 & $100^{*}$ & 9 & $81,2^{* *}$ & 23 & $88,46^{*}$ & 71 & $54,20^{*}$ & 91 & $62,76^{*}$ & 7 & 14,89 & 4 & 9,09 & 78 & $24,22^{*}$ & 95 & $26,99^{2}$ \\
\hline Leite & 85 & $87,63^{*}$ & 87 & $82,66^{*}$ & 15 & $65,22^{*}$ & 6 & $42,86^{*}$ & 8 & $72,73^{*}$ & 20 & $76,92^{*}$ & 108 & $82,4^{*}$ & 113 & $77,93^{*}$ & 45 & $95,74^{*}$ & 21 & $47,73^{*}$ & 153 & $47,2^{*}$ & 134 & $38,07 *$ \\
\hline chá & 13 & 13,40 & 6 & 5,71 & 8 & 34,78 & 2 & 14,29 & 2 & 18,18 & 4 & 15,38 & 23 & 17,56 & 12 & 8,28 & 1 & 2,13 & 0 & 0,00 & 24 & 7,45 & 12 & 3,41 \\
\hline Suco nat. de fruta & 19 & 19,59 & 15 & 14,29 & 4 & 17,39 & 3 & 21,43 & 3 & 27,27 & 5 & ${ }_{19,23}$ & 26 & 19,85 & 23 & 15,86 & 6 & 12,77 & 10 & 22,73 & 32 & 9,94 & 33 & 9,38 \\
\hline Suco artificicial & 11 & 11,34 & 5 & 4,76 & 5 & 21,74 & 4 & 28,57 & 3 & 27,27 & 1 & 3,85 & 19 & 14,50 & 10 & 6,90 & 3 & 6,38 & 5 & 11,36 & 22 & 6,83 & 15 & 4,26 \\
\hline Iogurte & 17 & 17,53 & 14 & 13,33 & 4 & 17,39 & $2^{2}-1$ & 14,29 & 3 & 27,27 & 2 & 7,69 & 24 & 18,32 & 18 & 12,41 & 5 & 10,64 & 1 & 2,27 & 29 & 9,01 & 19 & 5,40 \\
\hline pào & 91 & $93,81^{*}$ & 100 & $95,24^{*}$ & 22 & $95,65^{*}$ & 14 & ${ }^{100^{*}}$ & 10 & ${ }_{90,91^{*}}$ & 23 & $88,46^{*}$ & 123 & $93,89^{*}$ & 137 & $94,48^{*}$ & 25 & $53,19^{*}$ & 25 & $56,82^{*}$ & 148 & $45,96^{*}$ & 162 & $46,02^{*}$ \\
\hline Bolacha & 47 & $48,45^{*}$ & 43 & $40,95^{*}$ & 13 & $56,5^{2 *}$ & 5 & $35,71^{*}$ & 3 & 27,27 & 4 & 15,38 & 63 & $48,09^{*}$ & 52 & $35,86^{*}$ & 15 & $31,91^{*}$ & 15 & $34,09^{*}$ & 78 & $24,22^{*}$ & 67 & $19,03^{*}$ \\
\hline Bolo & 22 & 22,68 & 30 & 28,57 & 11 & 47,83 & 5 & 35,71 & 1 & 9,09 & 8 & 30,77 & 34 & 25,95 & 43 & 29,66 & 15 & 31,91 & 15 & $34,09^{*}$ & 49 & 15,22 & 58 & 16,48 \\
\hline Biscoito & 18 & 18,56 & 14 & 13,33 & 10 & 43,48 & 2 & 14,29 & & & 2 & 7,69 & 28 & 21,37 & 18 & 12,41 & 7 & 14,89 & 2 & 4,55 & 35 & 10,87 & 20 & 5,68 \\
\hline Quejio & 22 & 22,68 & 24 & 22,86 & 7 & 30,43 & 5 & 35,71 & 4 & $36,36^{*}$ & 5 & 19,23 & 33 & 25,19 & 34 & 23,45 & 9 & $19,15^{*}$ & 7 & 15,91 & 42 & 13,04 & 41 & 11,65 \\
\hline Requeujajo & 18 & 18,56 & 28 & 26,67 & 6 & 26,09 & 6 & 42,86 & 3 & 27,27 & 6 & 23,08 & 27 & 20,61 & 40 & 27,59 & 14 & $29,79^{*}$ & 14 & $31,82^{*}$ & 41 & 12,73 & 54 & 15,34 \\
\hline Manteiga & 41 & $42,27^{*}$ & 49 & $46,67^{*}$ & 17 & $73,91^{*}$ & 11 & $78,57^{*}$ & 7 & $63,64^{*}$ & 12 & $46,15^{*}$ & 65 & $49,62^{*}$ & 72 & $49,66^{*}$ & 9 & $19,15^{*}$ & 14 & $31,82^{*}$ & 74 & $22,98^{*}$ & 86 & $24,43^{*}$ \\
\hline Marganina & 23 & 23,71 & 29 & 27,62 & 7 & 30,43 & 4 & 28,57 & 2 & 18,18 & 10 & $38,46^{*}$ & 32 & 24,43 & 43 & 29,66 & 6 & 12,77 & 10 & 22,73 & 38 & 11,80 & 53 & 15,06 \\
\hline Pressumto & 22 & 22,68 & 27 & 25,71 & 7 & 30,43 & 5 & 35,71 & 4 & $36,36^{*}$ & 3 & 11,54 & 33 & 25,19 & 35 & 24,14 & 7 & 14,89 & 3 & 6,82 & 40 & 12,42 & 38 & 10,80 \\
\hline Mortadela & 13 & 13,40 & ${ }_{11}^{11}$ & 10,48 & 9 & 39,13 & 6 & 42,86 & 4 & $36,36^{*}$ & 3 & 11,54 & 26 & 19,85 & 20 & 13,79 & 6 & 12,77 & 0 & 0,00 & 32 & 9,94 & 20 & 5,68 \\
\hline Ovos & 9 & 9,28 & 4 & 3,81 & 5 & 21,74 & 5 & 35,71 & 2 & 18,18 & 3 & 11,54 & 16 & 12,21 & 12 & 8,28 & 2 & 4,26 & 0 & 0 & 18 & 5,59 & 12 & 3,41 \\
\hline Frutas & 24 & 24,74 & 25 & 23,81 & 7 & 30,43 & 5 & 35,71 & 3 & 27,27 & 8 & 30,77 & 34 & 25,95 & 38 & 26,21 & 8 & 17,02 & 12 & $27,27^{*}$ & 42 & 13,04 & 50 & 14,20 \\
\hline
\end{tabular}


Tabela 1B. No de alunos que assinalaram cada alimento as devidas porcentagens, referindo-se a que ingerem no CAFÉ DA MANHÃ. Escola Públicas de categoria B e Particulares $\beta$ (Zona Urbana). Piracicaba (SP), 2004

\begin{tabular}{|c|c|c|c|c|c|c|c|c|c|c|c|c|c|c|c|c|c|c|c|c|c|c|c|c|}
\hline \multirow[b]{2}{*}{ Alimentos } & \multicolumn{4}{|c|}{ EPU regular diurno } & \multicolumn{4}{|c|}{ EPU regular noturno } & \multicolumn{4}{|c|}{ EPU educacăo supletiva } & \multicolumn{4}{|c|}{ Total Escolas Püblicas } & \multicolumn{4}{|c|}{ EPA regular diurno } & \multicolumn{4}{|c|}{ TOTAL GERAL } \\
\hline & $\begin{array}{l}122 \\
\text { masc }\end{array}$ & $\%$ & $\begin{array}{l}102 \\
\text { fem }\end{array}$ & $\%$ & $\begin{array}{c}27 \\
\text { masc }\end{array}$ & $\%$ & $\begin{array}{cc}\begin{array}{c}38 \\
\text { fem }\end{array} & \text { Fem } \\
\end{array}$ & $\%$ & $\begin{array}{c}13 \\
\text { masc }\end{array}$ & $\%$ & $\begin{array}{l}{ }_{\mathrm{fem}}^{17} \\
\mathrm{feem}\end{array}$ & $\%$ & $\begin{array}{l}162 \\
\text { masc Masc }\end{array}$ & $\%$ & $\begin{array}{l}157 \\
\text { fem }\end{array}$ & $\%$ & $\begin{array}{c}28 \\
\text { masc }\end{array}$ & $\%$ & $\begin{array}{r}\begin{array}{r}13 \\
\text { fem }\end{array} \\
\text { Fen }\end{array}$ & $\%$ & $\begin{array}{l}190 \\
\text { masc Masc } \\
\text { masc }\end{array}$ & $\%$ & 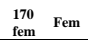 & $\%$ \\
\hline Café & 77 & $63,11^{*}$ & 55 & $53,92^{*}$ & 22 & $81,48^{*}$ & 28 & $73,66^{*}$ & 7 & $53,85^{*}$ & 14 & $82,35^{*}$ & 106 & $65,43^{*}$ & 97 & $61,78^{*}$ & 16 & $57,14^{*}$ & 1 & 7,69 & 122 & $64,21^{*}$ & ${ }_{98}$ & $57,65^{*}$ \\
\hline Leite & 122 & $100^{*}$ & 101 & $99,02 *$ & 16 & $59,26^{*}$ & 34 & $89,47^{*}$ & 10 & $76,92^{*}$ & 16 & $94,12^{*}$ & 148 & $91,36^{*}$ & 151 & $96,18^{*}$ & 24 & $51,06^{*}$ & 10 & $\begin{array}{l}0 \\
06,92^{*}\end{array}$ & 172 & $90,53 *$ & 161 & $94,7^{*}$ \\
\hline chá & 7 & 5,74 & 3 & 2,94 & 3 & 11,11 & 1 & 2,63 & 0 & 0,00 & 0 & 0,00 & 10 & 6,17 & 4 & 2,55 & 1 & 2,13 & 0 & 0,00 & 11 & 5,79 & 4 & 2,35 \\
\hline Suco nat.de fruta & 21 & 17,21 & 18 & 17,65 & 6 & 22,22 & 10 & 26,32 & 3 & 23,08 & 1 & 5,88 & 30 & 18,52 & 29 & 18,47 & 3 & 6,38 & 0 & 0,00 & 33 & 17,37 & 29 & 17,06 \\
\hline Suco artificial & 4 & 3,28 & 7 & 6,86 & 5 & 18,52 & 5 & 13,16 & 2 & 15,38 & 1 & 5,88 & ${ }_{11}$ & 6,79 & 13 & 8,28 & 2 & 4,26 & 3 & $23,08^{*}$ & 13 & 6,84 & 16 & 9,41 \\
\hline logure & 16 & ${ }_{13,11}$ & 17 & 16,67 & 5 & 18,52 & 6 & 15,79 & 2 & 15,38 & 0 & 0,00 & 23 & 14,20 & ${ }^{23}$ & 14,65 & 4 & 8,51 & 2 & $15,38^{*}$ & 27 & 14,21 & 25 & 14,71 \\
\hline Pào & 122 & $100^{*}$ & 102 & $100^{*}$ & 24 & $88,89^{*}$ & 38 & $100^{*}$ & 12 & $92,31^{*}$ & 15 & $88,24^{*}$ & 158 & $97,53^{*}$ & 155 & $98,73^{*}$ & 23 & $48,94^{*}$ & 6 & $46,15^{*}$ & 181 & $95,26^{*}$ & 161 & $94,71^{*}$ \\
\hline Bolacha & 53 & $43,44^{*}$ & 51 & $50^{*}$ & 16 & $59,26^{*}$ & 25 & $65,79 *$ & 7 & $53,35^{*}$ & 5 & $29,41^{*}$ & 76 & $46,91^{*}$ & 81 & $51,59 *$ & 5 & 10,64 & 2 & $15,38^{*}$ & 81 & $42,63^{*}$ & 83 & $48,82^{*}$ \\
\hline Bolo & 31 & 25,41 & 40 & 39,22 & 15 & $55,56^{*}$ & 19 & 50 & 4 & 30,77 & 5 & $29,41^{*}$ & 50 & 30,86 & 64 & 40,76 & 6 & 12,77 & 2 & $155,38^{*}$ & 56 & 29,47 & 66 & 38,82 \\
\hline Biscoito & 16 & 13,11 & 20 & 19,61 & 10 & 37,04 & 10 & 26,32 & 2 & 15,38 & 2 & ${ }_{11,76}$ & 28 & 17,28 & 32 & 20,38 & 2 & 4,26 & 1 & 7,69 & 30 & 15,79 & 33 & 19,41 \\
\hline Quejio & 32 & 26,23 & 24 & 23,53 & 7 & 25,93 & 10 & 26,32 & 3 & 23,08 & 4 & 23,53 & 42 & 25,93 & 38 & 24,20 & 7 & 14,89 & 1 & 7,69 & 49 & 25,79 & 39 & 22,94 \\
\hline Requeijão & 28 & 22,95 & 33 & 32,35 & 3 & 11,11 & 11 & 28,95 & 1 & 7,69 & ${ }^{4}$ & 23,53 & 32 & 19,75 & 48 & 30,57 & 8 & $17,02^{*}$ & 2 & $15,33^{*}$ & 40 & 21,05 & 50 & 29,41 \\
\hline Manteiga & 67 & $54,92^{*}$ & 53 & $51,96^{*}$ & 15 & $55,56^{*}$ & 24 & $63,16^{*}$ & 7 & $53,35^{*}$ & 12 & $70,59 *$ & 89 & $54,94^{*}$ & 89 & $56,69 *$ & 14 & $29,79 *$ & 4 & $30,77^{*}$ & 103 & $54,21^{*}$ & 93 & $54,71^{*}$ \\
\hline Margarina & 33 & 27,05 & 32 & 31,37 & 7 & 25,93 & 12 & 31,58 & 0 & 0,00 & 5 & $29,41^{*}$ & 40 & 24,69 & 49 & 31,21 & 8 & $17,02^{*}$ & 1 & 7,69 & 48 & 25,26 & 50 & 29,41 \\
\hline Pressumto & 26 & 21,31 & 32 & 31,37 & 7 & 25,93 & 21 & 55,26 & 4 & 30,77 & 2 & ${ }_{11,76}$ & 37 & 22,84 & 55 & 35,03 & 4 & 8,51 & 1 & 7,69 & 41 & 21,58 & 56 & 32,94 \\
\hline Mortadela & 17 & 13,93 & 14 & 13,73 & 10 & 37,04 & 16 & 42,11 & 2 & 15,38 & 4 & 23,53 & 29 & 17,90 & 34 & 21,66 & 1 & 2,13 & 0 & 0,00 & 30 & 15,79 & 34 & 20,00 \\
\hline Ovos & 11 & 9,02 & 3 & 2,94 & 8 & 29,63 & 5 & ${ }_{13,16}$ & 4 & 30,77 & 0 & 0,00 & 23 & 14,20 & 8 & 5,10 & 1 & 2,13 & 1 & 7,69 & 24 & 12,63 & 9 & 5,29 \\
\hline Frutas & 27 & 22,13 & 23 & 22,55 & 7 & 25,93 & 11 & 28,95 & 4 & 30,77 & 3 & 17,65 & 38 & 23,46 & 37 & 23,57 & 6 & 12,77 & 1 & 7,69 & 44 & 23,16 & 38 & 22,35 \\
\hline
\end{tabular}


Tabela 1C. N ${ }^{\circ}$ de alunos que assinalaram cada alimento e as devidas porcentagens, referindo-se a que ingerem no CAFÉ DA MANHÃ. Escola Públicas de categoria Ce Particulares $\chi$ (Zona Urbana). Piracicaba (SP), 2004

\begin{tabular}{|c|c|c|c|c|c|c|c|c|c|c|c|c|c|c|c|c|c|c|c|c|c|c|c|c|}
\hline \multirow[b]{2}{*}{ Alimentos } & \multicolumn{4}{|c|}{ EPU regular diurno } & \multicolumn{4}{|c|}{ EPU regular noturno } & \multicolumn{4}{|c|}{ EPU educaaşăo supletiva } & \multicolumn{4}{|c|}{ Total Escolas Públicas } & \multicolumn{4}{|c|}{ EPA regular diurno } & \multicolumn{4}{|c|}{ TOTAL GERAL } \\
\hline & $\begin{array}{l}\text { 89 } \\
\text { masc } \\
\text { masc }\end{array}$ & $\%$ & $\begin{array}{l}72 \\
\text { fem }\end{array}$ & $\%$ & $\begin{array}{c}14 \\
\text { masc }\end{array}$ Masc & $\%$ & $\begin{array}{l}15 \\
\text { fem }\end{array}$ & $\%$ & $\underset{\text { masc }}{15}$ Masc & $\%$ & $\begin{array}{l}10 \\
\text { fem }\end{array}$ & $\%$ & $\begin{array}{l}118 \\
\text { masc }\end{array}$ & $\%$ & 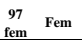 & $\%$ & $\begin{array}{l}17 \\
\text { masc Masc }\end{array}$ & $\%$ & $\begin{array}{l}19 \\
\text { fem }\end{array}$ & $\%$ & $\begin{array}{l}135 \\
\text { masc Masc } \\
\text { masc }\end{array}$ & $\%$ & $\begin{array}{l}116 \\
\text { fem }\end{array}$ & $\%$ \\
\hline Café & 58 & $65,17^{*}$ & 63 & $87,50^{*}$ & 12 & $85,71^{*}$ & 10 & $66,67 *$ & 13 & $86,67^{*}$ & 10 & $100^{*}$ & 83 & $70,34^{*}$ & 83 & $85,57^{*}$ & 6 & 35,29 & 7 & $36,84^{*}$ & 89 & $65,93^{*}$ & 90 & $77,59^{*}$ \\
\hline Leite & 89 & $100^{*}$ & 72 & $100^{*}$ & 12 & $85,7^{*}$ & 11 & $73,33^{*}$ & 10 & $66,67^{* *}$ & 9 & $90^{*}$ & 111 & $94,07^{*}$ & 92 & $94,85^{*}$ & 16 & $94,1^{*}$ & 16 & $84,21^{*}$ & 127 & $94,07 *$ & 108 & $93,10^{*}$ \\
\hline chă & 10 & 11,24 & 4 & 5,56 & 2 & 14,29 & 2 & 13,33 & 1 & 6,67 & 0 & 0 & 13 & 11,02 & 6 & 6,19 & 0 & 0,00 & 0 & 0,00 & 13 & 9,63 & 6 & 5,17 \\
\hline Suco nat. de fruta & 24 & 26,97 & 17 & 23,61 & 3 & 21,43 & 5 & 33,33 & 0 & 0,00 & 1 & 10 & 27 & 22,88 & 23 & 23,71 & 5 & 29,41 & 2 & 10,53 & 32 & 23,70 & 25 & 21,55 \\
\hline Succ artificial & 7 & 7,87 & 8 & 11,11 & 4 & 28,57 & 2 & ${ }_{13,33}$ & 2 & 13,33 & 1 & 10 & 13 & 11,02 & 11 & ${ }_{11,34}$ & 3 & 17,65 & 1 & 5,26 & 16 & 11,85 & 12 & 10,34 \\
\hline Iogurte & 14 & 15,73 & 12 & 16,67 & 3 & 21,43 & 3 & 20 & 0 & 0,00 & 0 & 0 & 17 & 14,41 & 15 & 15,46 & 2 & 11,76 & 3 & 15,79 & 19 & 14,07 & 18 & 15,52 \\
\hline Pão & 89 & $100^{*}$ & 72 & $100^{*}$ & 13 & $92,86^{*}$ & 15 & 100 & 13 & $86,67^{*}$ & 10 & $100^{*}$ & 115 & $97,46^{*}$ & 97 & $100^{*}$ & 16 & $94,12^{*}$ & 16 & $84,21^{*}$ & 131 & $97,04^{*}$ & 113 & $97,41^{*}$ \\
\hline Bolacha & 47 & $52,81^{*}$ & 55 & $76,39^{*}$ & 7 & $50^{*}$ & 8 & $53,33^{*}$ & 3 & $20^{*}$ & 3 & 30 & 57 & $48,31^{*}$ & 66 & $68,04^{*}$ & 8 & $47,06^{*}$ & 5 & 26,32 & 65 & $48,15^{*}$ & 71 & $61,21^{*}$ \\
\hline Bolo & 34 & 38,20 & 32 & 44,44 & 7 & $50^{*}$ & 9 & 60 & 2 & 13,33 & 3 & 30 & 43 & 36,44 & 44 & 45,36 & 4 & 23,53 & 7 & $36,84^{*}$ & 47 & 34,81 & 51 & 43,97 \\
\hline Biscoito & 27 & 30,34 & 22 & 30,56 & 4 & 28,57 & 8 & $53,33^{*}$ & 0 & 0,00 & 1 & 10 & 31 & 26,27 & 31 & 31,96 & 5 & 29,41 & 2 & 10,53 & 36 & 26,67 & 33 & 28,45 \\
\hline Quejio & 21 & 23,60 & 20 & 27,78 & 3 & 21,43 & 4 & 26,67 & 0 & 0,00 & 2 & 20 & 24 & 20,34 & 26 & 26,80 & 5 & 29,41 & 5 & 26,32 & 29 & 21,48 & 31 & 26,72 \\
\hline Requeijão & 22 & 24,72 & 23 & 31,94 & 5 & 35,71 & 4 & 26,67 & 0 & 0,00 & 3 & 30 & 27 & 22,88 & 30 & 30,93 & 8 & $47,06^{*}$ & 6 & 31,58 & 35 & 25,93 & 36 & 31,03 \\
\hline Manteiga & 47 & $52,81^{*}$ & 39 & $54,17^{*}$ & 9 & $64,29^{*}$ & 10 & $66,67^{*}$ & 9 & $60^{*}$ & 2 & 20 & 65 & $55,08^{*}$ & 51 & $52,58^{*}$ & 9 & $52,94^{*}$ & 9 & $47,37 *$ & 74 & $54,81^{*}$ & 60 & $51,72^{*}$ \\
\hline Margarina & 42 & 47,19 & 30 & 41,67 & 4 & 28,57 & 6 & 40 & 3 & $20^{*}$ & 4 & $40^{*}$ & 49 & 41,53 & 40 & 41,24 & 3 & 17,65 & 3 & 15,79 & 52 & 38,52 & 43 & 37,07 \\
\hline Presunto & 23 & 25,84 & 19 & 26,39 & 5 & 35,71 & 6 & 40 & 0 & 0,00 & 1 & 10 & 28 & 23,73 & 26 & 26,80 & 3 & 17,65 & 3 & 15,79 & 31 & 22,96 & 29 & 25 \\
\hline Mortadela & 24 & 26,97 & 17 & 23,61 & 7 & 50 & 8 & $53,33^{*}$ & 1 & 6,67 & 3 & 30 & 32 & 27,12 & 28 & 28,87 & 3 & 17,65 & 1 & 5,26 & 35 & 25,93 & 29 & 25 \\
\hline Ovos & 8 & 8,99 & 2 & 2,78 & 2 & 14,29 & 1 & 6,67 & 1 & 6,67 & 4 & $40^{*}$ & 11 & 9,32 & 7 & 7,22 & 0 & 0,00 & 0 & 0,00 & 11 & 8,15 & 7 & 6,03 \\
\hline Frutas & 25 & 28,09 & 22 & 30,56 & 5 & 35,71 & 3 & 20 & 0 & 0,00 & 4 & $40^{*}$ & 30 & 25,42 & 29 & 29,90 & 4 & 23,53 & 3 & 15,79 & 34 & 25,19 & 32 & 27,59 \\
\hline
\end{tabular}




\subsubsection{Quanto ao intervalo entre o café da manhã e o almoço}

Quanto aos alimentos ingeridos neste horário pode-se verificar na Figura 3 e nas Tabelas 2, 2A, 2B e 2C, entre outros aspectos:

\subsubsection{Comparando-se zona urbana e rural}

- que ingerem algum alimento nesse intervalo:

no ensino regular diurno urbano 75,81,\% dos alunos

no ensino regular diurno de zona rural $\quad 63,78 \%$ dos alunos

Verifica-se:

- que, no geral, em zona urbana, são maiores os percentuais de ingestão de alimentos no intervalo.

- que, considerando-se as escolas públicas do período diurno, os cinco alimentos mais escolhidos no referido intervalo, na mesma ordem tanto por alunos quanto por alunas de zona urbana, são, conforme Tabela 2:

$\begin{array}{ll}1^{\circ} \text { Bolachas } & \text { masculino }(58,70 \%) \text { e feminino }(58,42 \%) \\ 2^{\circ} \text { Salgadinhos } & \text { masculino }(36,59 \%) \text { e feminino }(52,24 \%) \\ 3^{\circ} \text { Doces } & \text { masculino }(35,87 \%) \text { e feminino }(49,85 \%) \\ 4^{\text {o }} \text { Frutas } & \text { masculino }(34,06 \%) \text { e feminino }(29,56 \%) \\ 5^{\circ} \text { Lanches } & \text { masculino }(30,43 \%) \text { e feminino }(25,67 \%)\end{array}$

Na população feminina, o percentual para suco natural é o mesmo que para os lanches.

- que, na zona rural houve diferenças na ordem dos alimentos mais ingeridos pela população masculina e feminina (Tabela 2).

Masculina

Feminina

$\begin{array}{lrll}1^{\circ} \text { Frutas } & 57,50 \% & 1^{\circ} \text { Bolachas } & 70,73 \% \\ 2^{\circ} \text { Bolachas e Doces } & 55,00 \% & 2^{\circ} \text { Frutas } & 56,10 \% \\ 3^{\circ} \text { Suco Natural de Frutas } & 42,50 \% & 3^{\circ} \text { Doces } & 43,90 \% \\ 4^{\circ} \text { Bolo } & 37,50 \% & 4^{\circ} \text { Salgadinhos } & 36,59 \% \\ 5^{\circ} \text { Pipocas } & 30,00 \% & 5^{\circ} \text { Suco Natural de Frutas } & 34,15 \%\end{array}$




\subsubsection{Comparando-se por período de funcionamento das escolas de zona urbana}

Percentuais de concluintes do ensino fundamental que consomem algum alimento entre o café da manhã e o almoço:

ensino regular diurno: $\quad 71,69 \%$ masculino e $79,57 \%$ feminino

ensino regular noturno: $\quad$ 92,96\% masculino e 86,11\% feminino

educação supletiva noturno: 65,52\% masculino e 89,71\% feminino (Tabela 2)

Observa-se:

- que os alunos de escolas públicas do período noturno (população masculina da rede regular e feminina da educação supletiva), são os que mais consomem alimentos no intervalo entre o café da manhã e o almoço.

- que em escolas públicas 24,19\% dos alunos do ensino regular diurno e $10,48 \%$ do ensino regular noturno não consomem nenhum alimento no intervalo entre o café da manhã e o almoço.

\subsubsection{Comparando-se por modalidade de curso}

$\mathrm{Na}$ rede regular de ensino é maior o percentual de alunos que consomem alimentos entre o café da manhã e o almoço (89,51\%), comparando-se com o percentual dos que o fazem na educação supletiva (78,57\%).

- das escolas públicas, não comem nenhum alimento entre o café da manhã e almoço: rede regular urbana $\quad 24,19 \%$ rede regular rural $\quad 36,22 \%$ rede regular noturno $\quad 10,49 \%$ rede de ed.supletiva $\quad 21,43 \%$

- das escolas particulares, nada comem 27,36 \% (Tabela 2); 


\subsubsection{Comparando-se por sexo, verifica-se:}

- que, nas escolas públicas, não comem nenhum alimento entre o café da manhã e almoço:

rede regular do diurno 28,31\% masculino e 20,43\% feminino

rede regular rural $\quad 36,51 \%$ masculino e $35,94 \%$ feminino

rede regular noturno $\quad 7,04 \%$ masculino e $13,89 \%$ feminino

rede de ed.supletiva $\quad 34,48 \%$ masculino e $11,48 \%$ feminino

- que nas escolas particulares nada consomem nesse horário 30\% de alunos do sexo masculino e $23,91 \% \%$ do feminino (Tabela 2).

- que $71,69 \%$ da população masculina e $79,57 \%$ da feminina consome algum alimento no referido intervalo em escolas públicas na rede regular de ensino diurno. (Tabela 2).

- que na zona rural o fazem 63,49\% da população masculina e 64,06\% da feminina, na mesma modalidade de escolas e curso.(Tabela 2)

\subsubsection{Comparando-se por categoria de escolas}

- que entre os que se alimentam neste intervalo, em escolas da categoria A e $\alpha$ :

. o maior percentual está entre alunos masculinos do ensino regular do período noturno $(95,65 \%)$ e é menor entre todos, o percentual da população masculina de escolas particulares (51,06\% ) . (Tabela $2 \mathrm{~A})$.

. na população feminina, o maior percentual de consumo entre o café da manhã e o almoço está entre alunas da educação supletiva (97,06\%) e o menor, 79,39\%, entre alunas da rede pública de ensino regular diurno (Tabela 2 A).

Observa-se que a maioria da população feminina consome alimentos entre o café da manhã e o almoço; que o menor consumo, tanto na população feminina quanto 
masculina, ocorre nas escolas particulares, onde qualquer alimento precisa ser comprado nas cantinas.

Comparando-se a rede regular de ensino noturno com a educação supletiva, vê-se que a população masculina da primeira e feminina da segunda são os que indicam maiores percentuais de ingestão de alimentos entre o café da manhã e almoço (Tabela 2A).

Observando-se a Tabela 2A, ainda se percebe:

- que, quanto aos salgadinhos e lanches, nota-se maior ingestão entre estudantes de escolas particulares tanto do sexo masculino como feminino;

- que frutas não figuram entre os cinco primeiros alimentos escolhidos, somente na população masculina da educação supletiva;

- que pipoca é um alimento ingerido com destaque somente pela população feminina da educação supletiva (53,33\%) e o menos consumido por quaisquer outros grupos de alunos em estudo; cabe lembrar que esses alunos também não recebem merenda nas escolas.

- que batatas fritas só são consumidas com destaque por alunos do sexo masculino de escolas públicas com ensino regular noturno (36,36\%);

- que é observável a preferência de ingestão de sucos naturais aos artificiais;

- que é destacada a ingestão de café entre o café da manhã e o almoço apenas por alunos que freqüentam aulas no período noturno (ensino regular e educação supletiva); cumpre lembrar que são alunos adultos, a grande maioria inserida no mercado de trabalho e que, na realidade piracicabana, é comum as empresas servirem café nos ambientes de trabalho.

- que bolo, chá e suco articial não são alimentos ingeridos com destaque por alunos de escolas de categoria A e $\alpha$.

- que entre os que se alimentam neste intervalo em escolas da categoria $B$ e $\beta$ 
. o maior percentual entre a população masculina está no ensino regular noturno (93,33\%) e o menor, 69,28\%, em alunos das escolas públicas do ensino regular diurno. . na população feminina, o maior percentual, 90,48\%, está entre as alunas da educação supletiva e o menor, 54,55\%, na rede regular de ensino das escolas particulares.

Verifica-se, observando-se a tabela 2B, nestas escolas:

- que a população masculina e feminina apresentam percentuais semelhantes de ingestão de alimentos entre o café da manhã e o almoço;

- que apenas entre alunos da educação supletiva, salgadinhos e lanches não figuram entre os cinco mais consumidos;

- que bolo figura entre os cinco alimentos mais consumidos apenas entre alunos da rede regular de ensino noturno e de educação supletiva;

- que as frutas só não figuram entre os cinco itens mais consumidos entre a população masculina das escolas públicas com ensino regular noturno e feminina das escolas particulares com ensino regular diurno;

- que a ingestão de suco artificial somente figura com destaque entre alunos de escolas públicas de ensino regular diurno.

- que o café é consumido com destaque apenas por alunos do período noturno (rede regular de ensino e educação supletiva).

- que entre os que se alimentam nesse intervalo em escolas de categoria $\mathrm{C}$ e $\chi$ :

- o maior percentual de consumo entre o café da manhã e o almoço está entre a população masculina, de escolas públicas de ensino regular noturno $(88,89 \%)$ e o menor, 70,59\%, entre os alunos de escolas públicas de educação supletiva .

- na população feminina, o maior percentual de consumo de alimentos no horário (87,27\%) está em alunas de escolas públicas do ensino regular diurno; o menor, 72,73\%, está entre alunas de escolas públicas, da educação supletiva.

Observando-se a Tabela 2C ainda se verifica: 
- que apenas a população masculina das escolas particulares, com ensino regular diurno, não tem as frutas como destaque entre as cinco primeiras escolhas no intervalo entre o café da manhã e o almoço;

- que o lanche só não está entre as cinco primeiras escolhas entre alunos que estudam em período noturno, quer na rede regular ou de educação supletiva;

- que os alunos de educação supletiva não têm o hábito de ingerir salgadinhos neste horário; apenas um elemento do sexo masculino fez a indicação do alimento;

- que bolo não é ingerido com destaque nesse horário por alunos da rede regular de ensino diurno; apenas um estudante do sexo masculino de escolas particulares fez a indicação;

- que o café só obteve destaque na escolha, entre alunos da educação supletiva; não teve nenhuma indicação entre alunos da rede de escolas particulares;

- que batata frita não é consumida com destaque entre o café da manhã e o almoço por nenhum grupo de alunos das escolas de categoria;

- que bolachas receberam destaque entre as cinco primeiras escolhas em todos os grupos de alunos das escolas de categoria. 


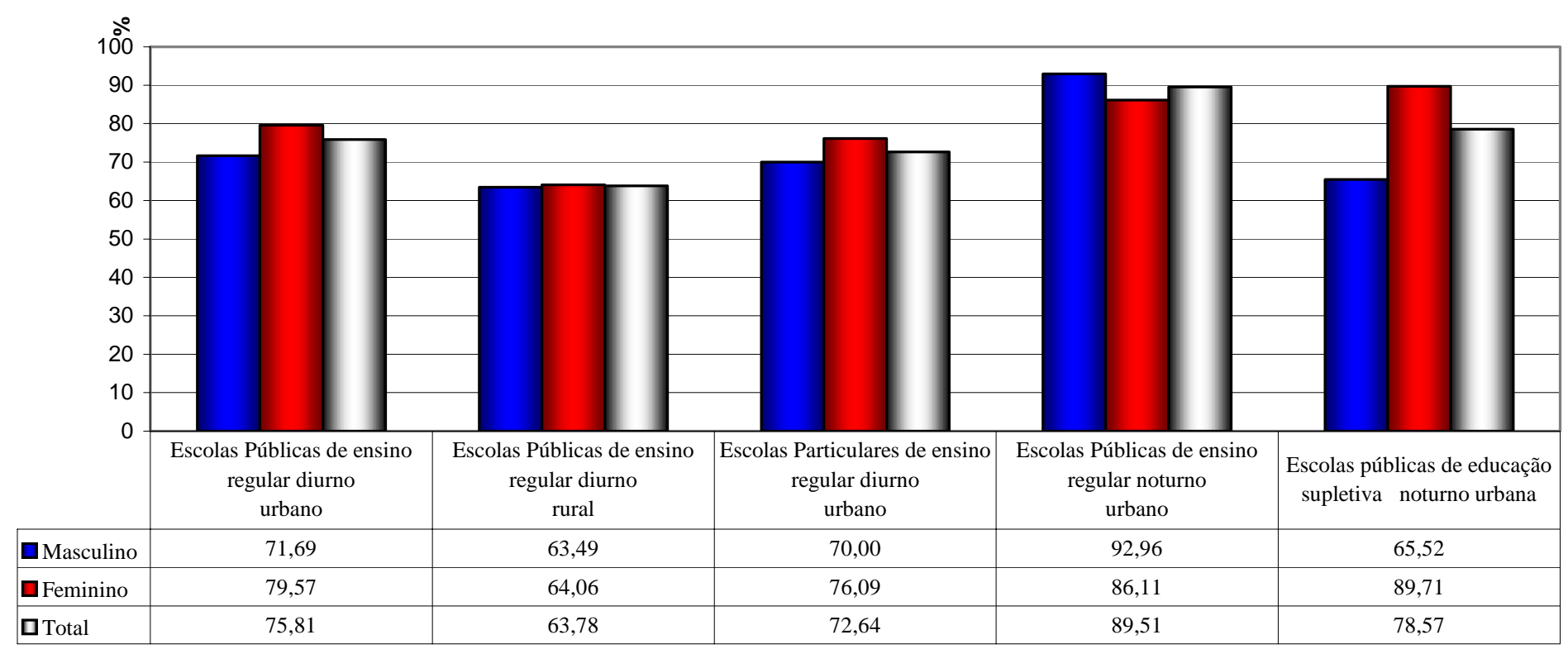

Figura 3 Percentuais de alunos de escolas públicas e particulares de diferentes categorias que manhã e o almoço Piracicaba(SP), 2004

ingerem alimentos entre o café da 


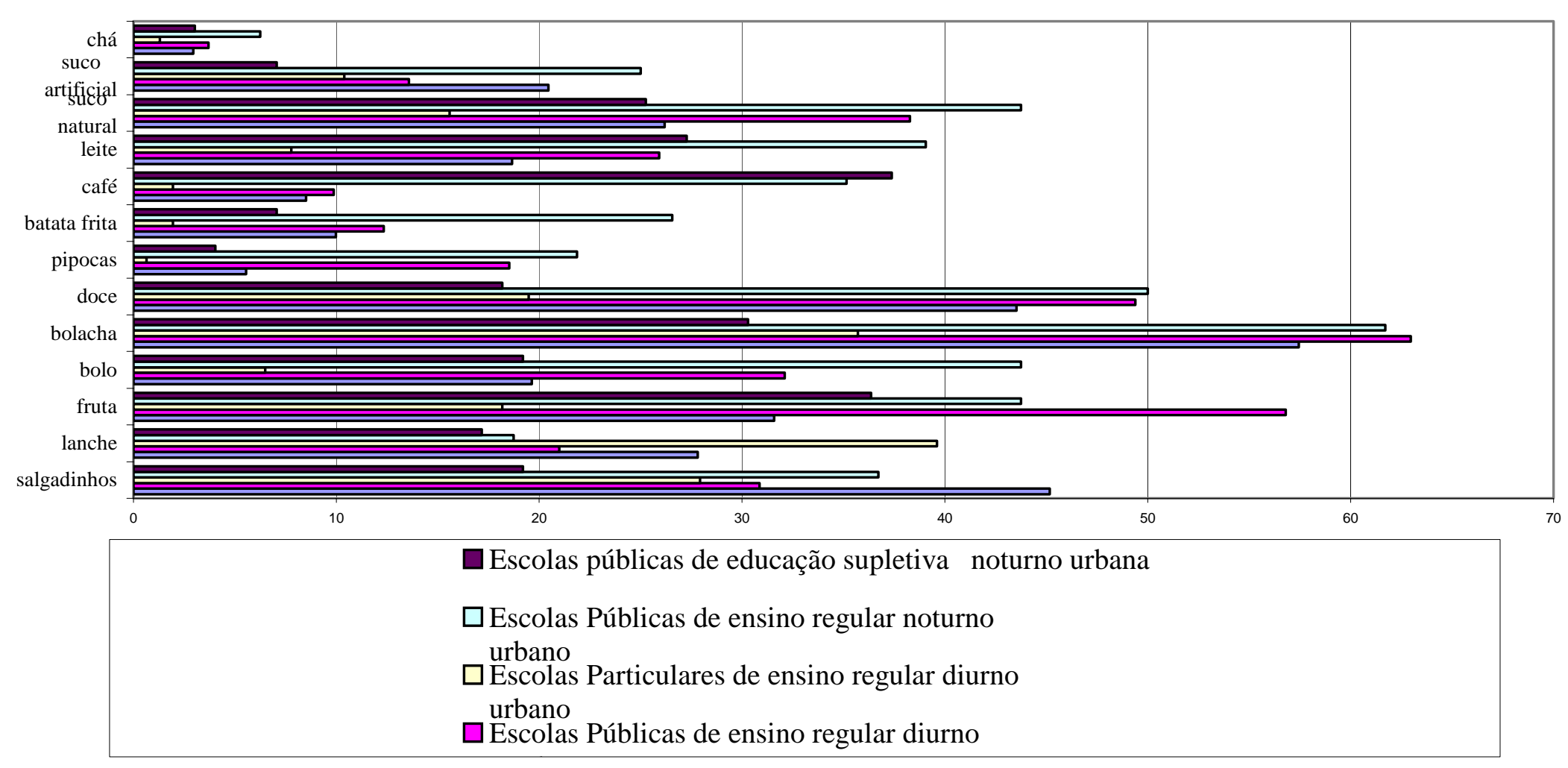

Figura 4 Alimentos ingeridos entre o café da manhã e o almoço- Piracicaba (SP), 2004 


\begin{tabular}{|c|c|c|c|c|c|c|c|c|c|c|c|c|c|c|c|c|c|c|c|c|c|c|c|c|c|c|c|c|c|c|c|c|c|}
\hline Alimaners & 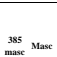 & Froblt & 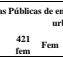 & $\%$ & thimb & Toual & $\%$ & $\underset{\text { max }}{\mathbb{B a x}} \max$ & Exochat & 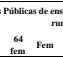 & tits & 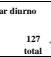 & & $\%$ & 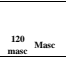 & roxalus & 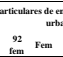 & "stit & 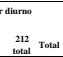 & $\%$ & 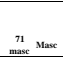 & Escolt & 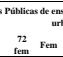 & 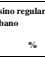 & natum & & $\%$ & 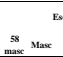 & 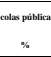 & 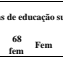 & 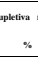 & 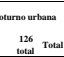 & $\%$ \\
\hline conomerm & 276 & 7,ts9 & us & $n p^{\prime}$ & on & & 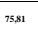 & ${ }^{\circ \circ}$ & 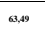 & "A & a,tare & " & & 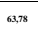 & a4 & $20,0,0$ & $\begin{array}{ll}70 \\
\end{array}$ & ${ }_{7, \omega}$ & 1st & 72,as & "6 & 82,286 & ${ }^{\circ a}$ & sa,11 & ${ }^{\mathrm{v} x \mathrm{~B}}$ & & ons, & 38 & 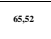 & "1 & $\begin{array}{ll}\mathrm{m}, \mathrm{n}, \mathrm{n} \\
\end{array}$ & 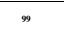 & 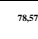 \\
\hline 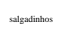 & ${ }_{100}^{100}$ & 3ass & 175 & ${ }_{522}^{22}$ & & 276 & si, 1 r & 10 & ${ }^{25}$ & 15 & $3,5,59$ & & 25 & 30,166 & ${ }^{24}$ & $2,4,5 x$ & 19 & $2,1, a t$ & ${ }_{43}$ & 27,92 & 19 & 2a,79 & ${ }^{28}$ & ${ }_{s, 1,100}$ & & 47 & $\mathrm{x}, \mathrm{z}$ & 13 & $3,2,2$ & ' & ges & 19 & 19,19 \\
\hline Intante & ${ }^{84}$ & sa,s & 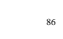 & 25,6 & & 100 & r,are & . & ${ }_{20} 0$ & . & 21,95 & & 17 & $20,0,9$ & æ & 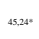 & ${ }_{23}$ & ${ }_{32, \infty}$ & 6 & 3,96- & 13 & 19:70 & " & $\mathrm{b}, 7, \mathrm{~A}$ & & ${ }_{24}$ & 1017,5 & " & 2a:5s & 6 & 9,4 & r & $1, x$ \\
\hline thene & s4 & I3,506 & $\infty$ & $29,5.5$ & & 198 & 31,50 & ${ }_{23}$ & $5,5,50$ & 23 & salar & & 46 & 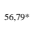 & ${ }_{14}$ & ${ }_{16,67}$ & ${ }_{14}$ & 20 & ${ }^{28}$ & tal, & ${ }_{2 n}$ & $40,29 x^{*}$ & ${ }^{20}$ & ${ }_{0,150}$ & & 56 & $4,35$. & 12 & 31,58 & ${ }^{24}$ & $3,3,45$ & 35 & 36,56 \\
\hline wato & s4 & 1957 & $\infty$ & 19,7 & & ${ }^{200}$ & 19,84 & is & $3,5,50$ & "1 & 26,83 & & 26 & D:,100 & . & $7,4.4$ & . & $\mathrm{s}, 7$ & 10 & 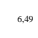 & ${ }_{24}$ & 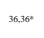 & 12 & ${ }_{5, s, s t}$ & & 56 & $4,350^{\circ}$ & , & $2,3,8$ & 10 & 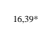 & 19 & 19,19 \\
\hline bialiata & ${ }_{12} 12$ & $\sin r m$ & 19 & $s, a, a$ & & 31 & $5,455^{\circ}$ & ${ }_{22}$ & $s$ & ${ }_{29}$ & 70,75 & & 51 & 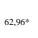 & $\infty$ & ${ }_{3,3, n}$ & ${ }_{25}$ & ${ }_{3, \pi}, \pi$ & $\mathrm{ss}$ & ${ }_{33,7}$ & 42 & sasese & ${ }^{3} y$ & ${ }_{s, s, \infty}$ & & 7 & ब, $1, r^{*}$ & ${ }_{16}$ & $0,11{ }^{2}$ & ${ }_{14}$ & $22,55$. & $\infty$ & 30,00 \\
\hline dice & 99 & 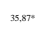 & 107 & 4a,a: & & 266 & as.5." & 22 & 55 & 18 & ${ }^{43900}$ & & 40 & 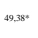 & ${ }_{15}$ & $1, \pi, a c=$ & is & $2,1, a^{\circ}$ & so & $1,9,400$ & ${ }^{24}$ & $36,66 e^{-2}$ & 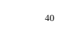 & $6,1,22^{2}$ & & sa & $\mathrm{ser}$ & 10 & 26,12 & $\mathrm{~s}$ & ${ }_{13,1}$ & 18 & 18,14 \\
\hline pipocas & ${ }^{14}$ & $\mathrm{s,07}$ & 20 & $5,9,9$ & & s & 5,56 & 12 & so & 3 & 7,72 & & 15 & $10,2,2$ & . & 1.19 & 。 & $0,0,00$ & ' & 0.05 & , & 13,34 & 19 & 30,05 & & ${ }_{28}$ & 2,1,as & $=$ & 525 & $=$ & ${ }_{3 x} x$ & a & 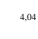 \\
\hline 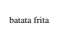 & ${ }_{27}$ & $\mathrm{~s}, \mathrm{~m}$ & ${ }^{*}$ & 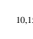 & & " & $s, a$ & s & 12500 & s & ${ }_{1220}^{120}$ & & 10 & $1,2,5$ & $=$ & $2,3.8$ & I & $1, s$, & 3 & 1.95 & 19 & $2 a, 79$ & 15 & 24,19 & & 34 & 25566 & s & ${ }_{13,16}$ & $=$ & $32 a$ & & 7,07 \\
\hline owik & 29 & 1051 & ${ }^{23}$ & 60 & & $=$ & $\mathrm{s}, \mathrm{s} 1$ & 4 & 10 & . & $9,7,6$ & & 8 & , stig & $=$ & 2,38 & 1 & 1,43 & 3 & 1.95 & ${ }^{24}$ & $33,60 e^{-}$ & ${ }^{21}$ & $\mathrm{~s}, \mathrm{~s}, \mathrm{z}$ & & 45 & s,16 & 18 & 4,37 & 19 & $3,1,5-$ & 3 & $y, 37$ \\
\hline telie & 63 & $2,2,33$ & st & 15,2 & & ${ }_{114}^{14}$ & 18, & 10 & 25 & " & $26 \mathrm{sas}$ & & ${ }^{21}$ & $2,5,93$ & . & $0,2,2$ & 4 & $5, n$ & ${ }_{12}$ & 7,79 & ${ }^{28}$ & 42,202 & ${ }^{2}$ & 35, At & & so & sa,66 & 18 & $4,35 \%$ & . & 14,75 & 27 & 2,277 \\
\hline $\begin{array}{l}\text { seron } \\
\text { sumat }\end{array}$ & ${ }_{74}$ & 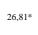 & ${ }^{66}$ & 25,6 & & 100 & 2,19 & ${ }_{17}$ & 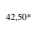 & ${ }_{14}$ & 34,15 & & 3 & $s_{3} 2 x-2 r$ & ${ }_{16}$ & $1,0,05$ & 8 & u,s & ${ }^{24}$ & ${ }_{1558}$ & $\approx$ & 439. & ${ }_{27}$ & $0,0,5$ & & 36 & $43,55^{\circ}$ & 14 & $3,8,8 n^{\circ}$ & "1 & Ita, & 25 & $2,3,5-$ \\
\hline 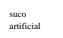 & 42 & 1,522 & 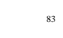 & 2,77 & & ${ }_{155}$ & 20,68 & , & $15: 50$ & 4 & ${ }_{9,76}$ & & " & $1,: 58$ & 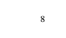 & $0,5,2$ & 8 & ${ }_{1,43}$ & 16 & $\begin{array}{l}10,999 \\
0\end{array}$ & 21 & $3,1,22$ & " & 17,74 & & 32 & 25 & 4 & 10,8s & 3 & 4,2 & , & 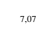 \\
\hline as & " & 3,90 & , & 2,00 & & 19 & 2.95 & 。 & ,a, & 3 & 7,27 & & 3 & 370 & & ,.19 & & 1,43 & & 1.00 & . & , som & $=$ & 322 & & 8 & 6,25 & I & 208 & $=$ & $3: 3$ & ${ }^{3}$ & $3, m$ \\
\hline 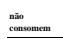 & 100 & 2031 & 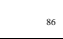 & 20.7 & & 105 & 2,199 & ${ }_{23}$ & s.sis & ${ }_{23} 3$ & s,sed & & ${ }^{45}$ & 3652 & $\%$ & ${ }_{30}^{30}$ & ${ }_{22}$ & 29,91 & $\mathrm{sB}$ & 2736 & 5 & ${ }_{704}$ & 10 & ${ }_{13, a s}$ & & 15 & 10,499 & 20 & s.4. & , & 11,4.8 & 27 & $2, a$ \\
\hline
\end{tabular}




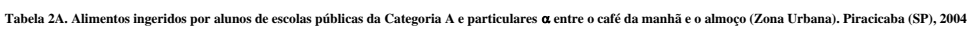

\begin{tabular}{|c|c|c|c|c|c|c|c|c|c|c|c|c|c|c|c|c|c|c|c|c|c|c|c|c|}
\hline \multirow[b]{2}{*}{ Alimentus } & \multicolumn{4}{|c|}{ EPU regular diumo } & \multicolumn{4}{|c|}{ EPU regular noturno } & \multicolumn{4}{|c|}{ EPU educacasôs supletiva } & \multicolumn{4}{|c|}{ Total Escolas Publicias } & \multicolumn{4}{|c|}{ EPA regular diurno } & \multicolumn{4}{|c|}{ TOTAL GERAL } \\
\hline & 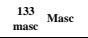 & $\%$ & 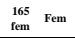 & $\%$ & $\begin{array}{c}\text { 年asc Masc } \\
\text { mase }\end{array}$ & $\%$ & $\underset{\text { tem }}{17}$ Fem & $\%$ & $\begin{array}{c}19 \\
\text { mase Masc } \\
\text { mact }\end{array}$ & $\%$ & 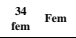 & $\%$ & $\begin{array}{l}\text { 年 } \\
\text { mase Mase }\end{array}$ & $\%$ & 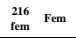 & $\%$ & $\begin{array}{l}\text { 每asc Masc } \\
\text { masc }\end{array}$ & $\%$ & $\underset{\substack{\text { tem } \\
\text { fem }}}{\text { Fem }}$ & $\%$ & $\begin{array}{l}\text { 2222 Masc } \\
\text { masc Mas }\end{array}$ & $\%$ & $\begin{array}{l}\text { lem } \\
\text { lem }\end{array}$ & $\%$ \\
\hline Consomen & 94 & 70,68 & 131 & 79,39 & 22 & $\begin{array}{ll}95,65 \\
\end{array}$ & 15 & 88,24 & 15 & 78,95 & 33 & $\begin{array}{ll}7,06 \\
\end{array}$ & 131 & 74,86 & 179 & 82,87 & 24 & 51,06 & ${ }_{41}$ & 87,23 & 155 & 69,82 & 220 & 83,65 \\
\hline salagatinhos & 21 & $22,34^{*}$ & 35 & $26,7^{2 *}$ & 8 & $36,36^{*}$ & 4 & 26,67 & 6 & $40^{*}$ & 3 & 9,09 & 35 & $26,7^{*}$ & 42 & $23,46^{*}$ & ${ }_{12}$ & ${ }^{50 *}$ & 9 & $21,95 *$ & ${ }^{47}$ & $30,32^{*}$ & ${ }^{51}$ & $23,18^{*}$ \\
\hline lanche & 17 & 18,99 & ${ }^{24}$ & 18,32 & 3 & 13,64 & 2 & 13,33 & 7 & $46,67 *$ & 3 & 9,09 & ${ }^{27}$ & 20,61 & 29 & 16,20 & 16 & $66,67 *$ & ${ }^{11}$ & $26,83^{*}$ & ${ }^{43}$ & $27,74^{*}$ & ${ }_{40}$ & 18,18 \\
\hline trua & 30 & $31,91^{*}$ & 38 & $20,01^{*}$ & 13 & $59,09 *$ & ${ }^{8}$ & $53,33^{*}$ & 2 & ${ }_{13,33}$ & ${ }_{12}$ & $36,36^{*}$ & 45 & $34,35^{*}$ & 58 & $32,40^{\circ}$ & 6 & ${ }^{25^{*}}$ & 9 & $21,95^{*}$ & ${ }^{51}$ & $32,900^{*}$ & 67 & $30,45^{*}$ \\
\hline bolo & 17 & 18,09 & 24 & ${ }_{18,32}$ & ${ }^{4}$ & ${ }_{18,18}$ & 5 & 33,33 & 0 & 0,00 & 3 & 9,09 & 21 & 16,03 & 32 & 17,88 & 3 & 12,50 & 3 & 7,32 & 24 & 15,48 & ${ }_{35}$ & 15,91 \\
\hline bolacha & 48 & $51,06^{*}$ & 65 & $49,22^{*}$ & 16 & $2,73^{*}$ & 6 & ${ }_{40}$ & 4 & 26,67 & 6 & ${ }_{18,11^{*}}$ & 68 & $51,9^{*}$ & 77 & ${ }^{43,02^{*}}$ & 16 & $66,67 *$ & 13 & ${ }^{31,77^{*}}$ & 84 & $54,19^{*}$ & 90 & $40,91^{*}$ \\
\hline doce & ${ }_{30}$ & $31,9^{*}$ & 49 & $37,40^{*}$ & 7 & 31,82 & ${ }_{10}^{10}$ & $66,67 *$ & 2 & ${ }_{13,33}$ & 1 & 3,03 & 39 & $29,77^{*}$ & 60 & $33,52^{*}$ & 3 & 12,50 & ${ }_{10}^{10}\left(\begin{array}{ll} \\
0\end{array}\right.$ & $24,399^{*}$ & ${ }^{42}$ & 27,10 & 70 & $31,2^{*}$ \\
\hline pipoeas & ${ }^{2}$ & 2,13 & 2 & 1,53 & 2 & 9,09 & 8 & $53,33^{*}$ & 0 & 0,00 & 0 & 0,00 & 4 & 3,05 & 10 & 5,59 & 0 & 0,00 & 0 & 0,00 & 4 & 2,58 & 10 & 4,55 \\
\hline banat frita & 9 & 9,57 & 10 & 7,63 & 8 & $36,36^{*}$ & 4 & 26,67 & 3 & 20 & 0 & 0,00 & 20 & 15,27 & 14 & 7,82 & 0 & 0,00 & 0 & 0,00 & 20 & 12,90 & 14 & 6,36 \\
\hline cate & 6 & 6,38 & ${ }_{10}$ & 7,63 & 8 & $36,36^{*}$ & 9 & ${ }^{60 *}$ & 6 & $4^{4}$ & 9 & $27,27 *$ & 20 & 15,27 & 28 & 15,64 & 1 & 4,17 & 1 & 2,44 & 21 & 13,55 & 29 & ${ }^{33,18}$ \\
\hline Ielie & 19 & 20,21 & 22 & $\begin{array}{l}16,79 \\
\text { e }\end{array}$ & 8 & $36,36^{*}$ & 5 & 33,33 & 5 & 33,33 & 4 & $12,12^{*}$ & 32 & 24,43 & 31 & 17,32 & ${ }_{4}^{4}$ & 16,67 & ${ }_{4}^{4}$ & 9,76 & 36 & 23,23 & 35 & 15,91 \\
\hline $\begin{array}{l}\text { seceo } \\
\text { naurual }\end{array}$ & 28 & $29,99^{*}$ & 32 & $24,43^{*}$ & 10 & $45,45^{\circ}$ & 7 & $46,677^{*}$ & 7 & $46,67 *$ & 6 & $18,11^{*}$ & 45 & $34,35^{*}$ & 45 & $25,14^{*}$ & 7 & $29,17 *$ & 2 & 4,88 & 52 & $33,55^{*}$ & 47 & $21,36^{*}$ \\
\hline 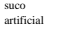 & ${ }^{12}$ & 12,77 & 30 & 22,90 & 4 & 18,18 & 4 & 26,67 & 2 & 11,33 & 0 & 0,00 & ${ }_{18}$ & 13,74 & ${ }^{34}$ & 18,99 & 3 & 12,50 & 3 & 7,32 & 21 & 13,55 & 37 & 16,82 \\
\hline chá & 3 & 3,19 & 3 & 2,91 & 2 & 9,09 & 1 & 6,67 & 1 & 6,67 & 2 & 6,06 & 6 & 4,58 & 6 & 3,35 & 0 & 0,00 & 0 & 0,00 & 6 & 3,87 & 6 & 2,73 \\
\hline $\begin{array}{l}\text { naia } \\
\text { consomemen }\end{array}$ & 39 & 29,32 & 34 & 33,01 & 1 & 4,35 & 2 & 11,76 & 4 & 21,05 & 1 & 2,94 & 44 & 25,14 & 37 & 17,13 & ${ }_{23}$ & 48,94 & 6 & 12,77 & 67 & 30,18 & ${ }_{43}$ & 16,35 \\
\hline
\end{tabular}




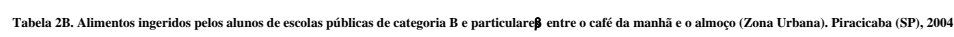

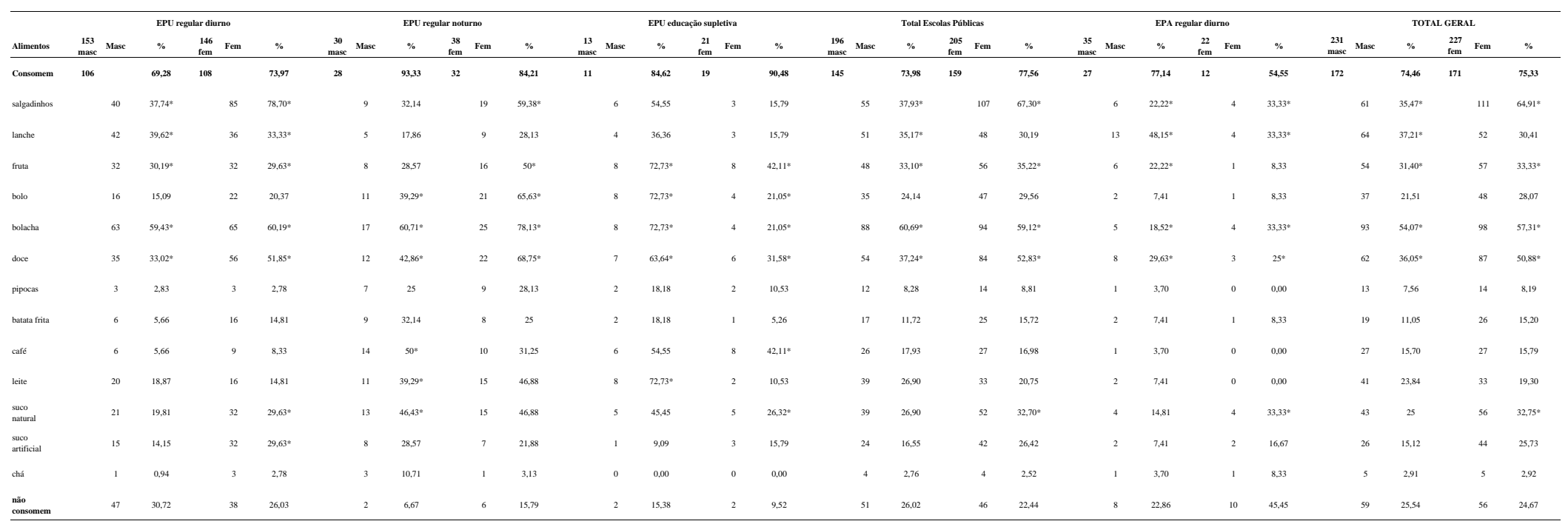


Tabela 2 C. Alimentos ingeridos pelos altuns de escolas püblicas de categoria Ce particulares $x$ entre o caté da manhãe e almoso (Zona Urbana), Piracicaba (SP), 2004

\begin{tabular}{|c|c|c|c|c|c|c|c|c|c|c|c|c|c|c|c|c|c|c|c|c|c|c|c|c|}
\hline \multirow[b]{2}{*}{ Alimentos } & \multicolumn{4}{|c|}{ EPU regular diurno } & \multicolumn{4}{|c|}{ EPU regular noturno } & \multicolumn{4}{|c|}{ EPV educasăós supleciva } & \multicolumn{4}{|c|}{ Total Escolas Püblicas } & \multicolumn{4}{|c|}{ EPA regular diurno } & \multicolumn{4}{|c|}{ TOTAL GERAL } \\
\hline & $\begin{array}{c}999 \\
\text { masc Masc }\end{array}$ & $\%$ & $\begin{array}{l}\text { Item } \\
\text { Fen }\end{array}$ & $\%$ & $\begin{array}{l}188 \text { Masc } \\
\text { masc }\end{array}$ & $\%$ & $\underset{\text { fem }}{15} \mathrm{Fer}$ & $\%$ & $\begin{array}{l}17 \\
\text { masc Masc } \\
\text { mas }\end{array}$ & $\%$ & $\underset{\text { tem }}{11} \mathrm{Fe}$ & $\%$ & 每asc Masc & $\%$ & $\begin{array}{l}\frac{136}{136} \mathrm{Fem} \\
\text { fem }\end{array}$ & $\%$ & 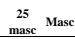 & $\%$ & 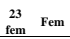 & $\%$ & $\begin{array}{l}159 \text { Masc } \\
\text { masc }\end{array}$ & $\%$ & $\underset{\substack{159 \\
\text { fem }} \text { Fem }}{ }$ & $\%$ \\
\hline Consomem & 76 & 76,77 & 96 & 87,27 & 16 & 88,89 & 13 & 86,67 & ${ }_{12}$ & 70,59 & 8 & 72,73 & 104 & 77,61 & 117 & 86,03 & 20 & 80 & 17 & 73,91 & 124 & 77,99 & 134 & 84,28 \\
\hline salagadinos & 40 & $52,63^{*}$ & 55 & $57,29^{*}$ & 2 & 12,50 & 4 & 30,77 & 1 & 8,33 & 。 & 0,00 & 43 & $41,35^{\circ}$ & 59 & 50,43. & 6 & ${ }_{30}{ }^{\circ}$ & 6 & $35,29^{\circ}$ & & ,952* & 65 & $48,51^{*}$ \\
\hline lanche & 25 & $32,89^{*}$ & 26 & $27,08^{*}$ & 5 & 31,25 & 0 & 0,00 & 0 & 0,00 & 。 & 0,00 & ${ }_{30}$ & 28,85 & 26 & 22,22 & 9 & ${ }_{45^{\circ}}$ & 8 & ${ }_{47,06^{\circ}}$ & 39 & 31,45 & ${ }_{34}$ & $25,33^{*}$ \\
\hline fruta & 32 & $42,12^{*}$ & 29 & $30,21^{*}$ & 7 & $43,5^{*}$ & ${ }^{4}$ & 30,77 & 2 & $16,67^{*}$ & s & ${ }^{50+}$ & ${ }_{41}$ & $39,42^{*}$ & 37 & 31,62 & 2 & 10 & 4 & $23,3^{*}$ & 43 & $34,68^{+}$ & 41 & $30,60^{*}$ \\
\hline bolo & ${ }_{21}$ & 27,63 & 20 & 20,83 & 9 & $56,25^{*}$ & 。 & 46,15 & 1 & 8,33 & & $37,50^{*}$ & 31 & 29,81 & 29 & 24,79 & 1 & 5 & 0 & 0,00 & 32 & 25,81 & 29 & ${ }_{21,64}$ \\
\hline bolacha & 51 & $67,1^{*}$ & 59 & $61,46^{*}$ & 9 & $56,25^{*}$ & 6 & $46,15-$ & 4 & $33,33^{*}$ & 4 & $50^{\circ}$ & 64 & $61,54 *$ & 69 & 58,977 & 9 & $4^{45^{\circ}}$ & 8 & $47,06^{\circ}$ & 73 & $58,87{ }^{\circ}$ & 77 & $57,4^{\circ}$ \\
\hline doce & 34 & $44,74^{*}$ & 62 & $64,58^{*}$ & 5 & 31,25 & 8 & 61,54 & 1 & 8,33 & & 12,50 & 40 & $38,46^{\circ}$ & 71 & $60,68-$ & 4 & $20^{\circ}$ & 2 & ${ }_{11,76}$ & 44 & $35,48^{\circ}$ & 73 & $54,48^{\circ}$ \\
\hline pipocas & 9 & ${ }_{11,84}$ & 15 & 15,63 & 0 & 0,00 & 2 & 15,38 & 0 & 0,00 & 。 & 0,00 & 9 & 8,65 & 17 & 14,53 & 。 & 0 & 0 & 0,000 & 9 & $\begin{array}{r}7,26 \\
\end{array}$ & 17 & 12,69 \\
\hline basata frita & 12 & 15,79 & 8 & 8,33 & 2 & 12,50 & 3 & 23,08 & 0 & 0,00 & & 12,50 & 14 & 13,46 & 12 & 10,26 & 。 & 0 & 0 & 0,00 & 14 & 11,29 & 12 & 8,96 \\
\hline cate & 17 & 22,37 & ${ }_{4}$ & ${ }_{4,17}$ & 2 & 12,50 & 2 & 15,38 & 6 & $50^{*}$ & 2 & $25^{*}$ & 25 & 24,04 & 8 & 6,84 & 。 & 0 & 0 & 0,00 & 25 & 20,16 & 8 & 5,97 \\
\hline leite & 24 & 31,58 & 13 & 13,54 & 9 & $56,25^{*}$ & 2 & 15,38 & 5 & $41,67^{*}$ & & $37,50^{*}$ & 38 & $36,54^{*}$ & 18 & 15,38 & 2 & 10 & 0 & 0,000 & 40 & $32,26^{\circ}$ & 18 & ${ }_{13,43}$ \\
\hline $\begin{array}{l}\text { suco } \\
\text { natural }\end{array}$ & 25 & $32,89^{*}$ & 22 & 22,92 & 6 & 37,50 & 5 & $38,46^{-}$ & 2 & $16,67^{*}$ & 。 & 0,000 & 33 & 31,73 & 27 & 23,08 & 5 & $25^{*}$ & 2 & 11,76 & 38 & 30,55 & 29 & 21,64 \\
\hline $\begin{array}{l}\text { suco } \\
\text { artificial }\end{array}$ & 15 & 19,74 & 21 & 21,88 & 9 & $56,2^{*}$ & 。 & 0,00 & 1 & 8,33 & . & 0,00 & 25 & 24,04 & ${ }_{21}$ & 17,95 & 3 & 15 & 3 & $17,65^{*}$ & 28 & 22,58 & 24 & 17,91 \\
\hline chả & 7 & 9,21 & 1 & 1,04 & 1 & 6,25 & o & 0,00 & 0 & 0,00 & 。 & 0,00 & 8 & 7,69 & 1 & 0,055 & 0 & 0 & 0 & 0,00 & 8 & 6,45 & 1 & 0,75 \\
\hline 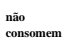 & 23 & 23,23 & 14 & 12,73 & 2 & 11,11 & 2 & 13,33 & 5 & 29,41 & & 27,27 & 30 & 22,39 & 19 & ${ }_{13,97}$ & 5 & 20 & 6 & 26,09 & 35 & 22,01 & 25 & 15,72 \\
\hline
\end{tabular}




\subsubsection{Quanto ao almoço}

Em escolas das categorias A, B, C (públicas) e $\alpha, \beta, \chi$ (particulares), do ensino regular e supletivo, diurno e noturno e também nas de zona rural, arroz e feijão constam como os alimentos preferidos pelos alunos em horário de almoço, seguidos de carne bovina, frango e verduras cruas.

\subsubsection{Comparando-se zona urbana e rural}

No cômputo geral, os cinco alimentos apontados como os mais consumidos entre os concluintes do ensino fundamental da rede regular de ensino diurno são:

- preferências registradas no ensino público, em zona urbana

Masculino

Feminino

$\begin{array}{llll}1^{\circ} \text { arroz } & 90,65 \% & 1^{\circ} \text { feijão e arroz } & 85,75 \% \\ 2^{\circ} \text { feijão } & 89,35 & 2^{\circ} \text { frango } & 60,10 \% \\ 3^{\circ} \text { carne de vaca } & 70,39 \% & 3^{\circ} \text { carne de vaca } & 51,07 \% \\ 4^{\circ} \text { frango } & 51,43 \% & 4^{\circ} \text { verdura crua } & 42,28 \% \\ 5^{\circ} \text { verdura crua } & 48,57 \% & 5^{\circ} \text { carne de porco } & 38,95 \%\end{array}$

- preferências registradas na rede regular de ensino público, na zona rural Masculino

Feminino

$\begin{array}{llll}1^{\circ} \text { arroz e feijão } & 92,06 \% & 1^{\circ} \text { arroz } & 89,06 \% \\ 2^{\circ} \text { carne de vaca } & 50,79 \% & 2^{\circ} \text { feijão } & 85,94 \% \\ 3^{\circ} \text { frango } & 47,62 \% & 3^{\circ} \text { frango } & 68,75 \% \\ 4^{\circ} \text { verdura crua } & 42,86 \% & 4^{\circ} \text { carne de vaca } & 59,38 \% \\ 5^{\circ} \text { macarrão } & 23,81 \% & 5^{\circ} \text { verdura crua } & 43,75 \%\end{array}$

Há preferência por carne bovina em escolas públicas e particulares em todas as categorias na zona urbana; na zona rural o frango tem a maior expressão percentual (Tabela 3, Quadro 7 e Figura 5). 
Peixe é a fonte proteica de origem animal menos consumida entre alunos de escolas públicas urbanas de categoria A (13,20\%) e B (19,73\%); nas escolas urbanas de categoria $\mathrm{C}$ e na zona rural a menor fonte protéica de origem animal provém dos embutidos, o mesmo ocorrendo nas escolas particulares $\alpha, \beta, \chi$ (Quadro 7).

\subsubsection{Comparando-se por período de funcionamento das escolas de zona urbana}

Os cinco primeiros alimentos escolhidos para o almoço são os mesmos, quer no período diurno ou noturno: arroz, feijão, carne bovina, frango e verduras cruas.

O macarrão ganha expressão de ingestão no almoço, 54,93\% entre os alunos do sexo masculino e 58,33\% entre os do sexo feminino da rede regular de ensino noturno (Tabela 3).

É maior a ingestão de verduras cruas entre alunos do período noturno, especialmente entre os da educação supletiva, muito provavelmente, por serem adultos e terem maior experiência de vida e consciência da importância da inclusão desse alimento. (Figura 5 e Tabela 3)

\subsubsection{Comparando-se por modalidade de curso}

Tanto na rede regular de ensino como na educação supletiva, os cinco alimentos mais escolhidos no almoço, no cômputo geral, são os mesmos anteriormente mencionados e na mesma ordem, lembrando-se da ênfase ao macarrão pelos alunos da rede regular de ensino noturno (Tabela 3).

\subsubsection{Comparando-se por sexo}

Observa-se que nas escolas da rede regular de ensino diurno de zona urbana das escolas públicas é maior o consumo de carne bovina entre os alunos do sexo masculino (70,39\%) e de carne de frango entre a população feminina (51,07\%) . 
Nas escolas particulares a carne bovina é mais consumida que o frango por ambos os sexos; entretanto, é maior o percentual da população feminina que ingere um e outro: 71,74\% para a carne bovina e 63,04\% para o frango.

Na zona rural o maior percentual de consumo de carne bovina e frango fica com a população feminina: 59,38\% para a carne bovina e 68,75\% para o frango; ocorre o mesmo entre as alunas da educação supletiva, que detém o maior percentual de ingestão: 86,76\% para a carne bovina e 76,47\% para o frango; na rede regular de ensino noturno a carne de frango é a preferida por ambos os sexos, no entanto a população feminina é detentora do maior percentual de consumo de uma e outra: 69,44\% para a carne bovina e $77,78 \%$ para o frango.

\subsubsection{Comparando-se por categoria de escolas, de acordo com as Tabelas 3A, 3B} e 3C

\subsection{Escolas de categoria A e $\alpha$}

- Quanto a preferência por carne bovina entre os alunos do ensino regular diurno na rede de escolas públicas , há um fato observado apenas nas escolas de categoria A: no caso da população feminina, o maior consumo é de carne de porco $(83,03 \%)$ (Tabela 3A).

- Entre os alunos do período noturno da rede regular de ensino público, a predominância é o consumo de carne de frango, tanto para o sexo masculino (69,57\%) como para o feminino (70,59\%) (Tabela 3A).

- Quanto à educação supletiva, os alunos consomem mais carne de frango $(81,82 \%)$ e as alunas, mais carne bovina $(76,47 \%)$ (Tabela 3A).

- Embutidos são a fonte de proteína animal menos consumida pelos alunos das escolas particulares e o peixe, o menos consumido por alunos de escolas públicas destas categorias (Quadro 7). 


\subsection{Escolas de categoria B e $\beta$}

- Nas escolas particulares de categoria $\beta$, período diurno, predomina o consumo de carne bovina (77,14\%\% para o sexo masculino e $72,73 \%$ para o feminino), sendo mínimo o consumo de embutidos (11,43\% para o sexo masculino e 18,18\% para o sexo feminino (Tabela 3B).

- Nas escolas públicas do período diurno, também há preferência pela carne bovina (76,47\% entre a população masculina e 87,67\% na feminina) (Tabela 3B).

- No curso regular de ensino público noturno, os alunos preferem carne bovina, sendo $60,00 \%$ o percentual para a população masculina e $87,50 \%$ para a população feminina; a segunda preferência é pela carne de frango, sendo 56,67\% no sexo masculino e $87,50 \%$ no sexo feminino. Apesar de não estar em posição de destaque entre os cinco alimentos mais apontados, 43,33 \% da população masculina e 50\% da feminina do curso noturno regular, incluem embutidos no almoço (Tabela 3B).

- Na educação supletiva predomina o consumo de carne de vaca entre os elementos do sexo masculino (72,22\%) e frango entre os do sexo feminino (71,43\%) (Tabela 3B).

- Os embutidos não são consumidos com destaque por alunos das categorias B e $\beta$; nesta última, os embutidos são os menos ingeridos entre as proteínas de origem animal (Quadro 7).

\subsection{Escolas de categoria C e $\chi$}

- Nas escolas públicas de ensino regular diurno, tanto públicas como particulares a população masculina e feminina demonstra consumir mais carne de vaca (75,76\% sexo masculino e $62,73 \%$ sexo feminino nas escolas públicas e $88,00 \%$ sexo masculino e 86,96\% sexo feminino nas escolas particulares) (Tabela 3C).

- No curso regular noturno da rede pública, predomina o consumo de frango entre a população masculina (77,78\%) e feminina (60,00\%) (Tabela 3 C). 
- Na educação supletiva demonstram consumir tanto carne de vaca quanto de frango, com ligeira preferência pelo frango na população feminina. Masculinos apontam $64,71 \%$ tanto para carne bovina quanto para frango e as alunas 33,33\% para carne bovina e 38,10\% para frango (Tabela 3C).

- Os embutidos constituem a proteína de origem animal menos ingerida entre alunos das categorias $\mathrm{C}$ e $\chi$.

-Entre outros alimentos, carne de porco e lanches não figuram entre as cinco primeiras escolhas no almoço, em nenhuma categoria de escolas (Tabela 3).

Outras observações gerais:

Há preferência por carne bovina em escolas públicas e particulares em todas as categorias na zona urbana; na zona rural o frango tem a maior expressão percentual (Tabela 3, Quadro 7 e Figura 5).

Peixe é a fonte protéica de origem animal menos consumida entre alunos de escolas públicas urbanas de categoria A (13,20\%) e B (19,73\%) (Quadro 7).

Embutidos são menos consumidos por alunos de escolas particulares, onde 10,00\% da população masculina inclui esse alimento no almoço e 13,04\% da população feminina, resultando um total de 11,32\% (Tabela 3). Na rede pública foi notado o menor consumo de embutidos entre a população masculina de zona rural $(11,11 \%)$ e feminina da educação supletiva (17,65\%). O maior consumo é registrado entre a população masculina $(42,25 \%)$ e feminina $(48,61 \%)$ de escolas públicas de ensino regular noturno (Tabela 3).

O Quadro 7 demonstra mais detalhes quanto as preferências gerais referentes às principais fontes de proteínas de origem animal consumidas no almoço, separadamente por categorias de escolas; as tabelas 3, 3A, 3B e 3C fornecem outros dados que podem ser comparados.

A figura 5 mostra, com clareza, outros alimentos incluídos no almoço pelos estudantes, nas diferentes categorias de escolas. 


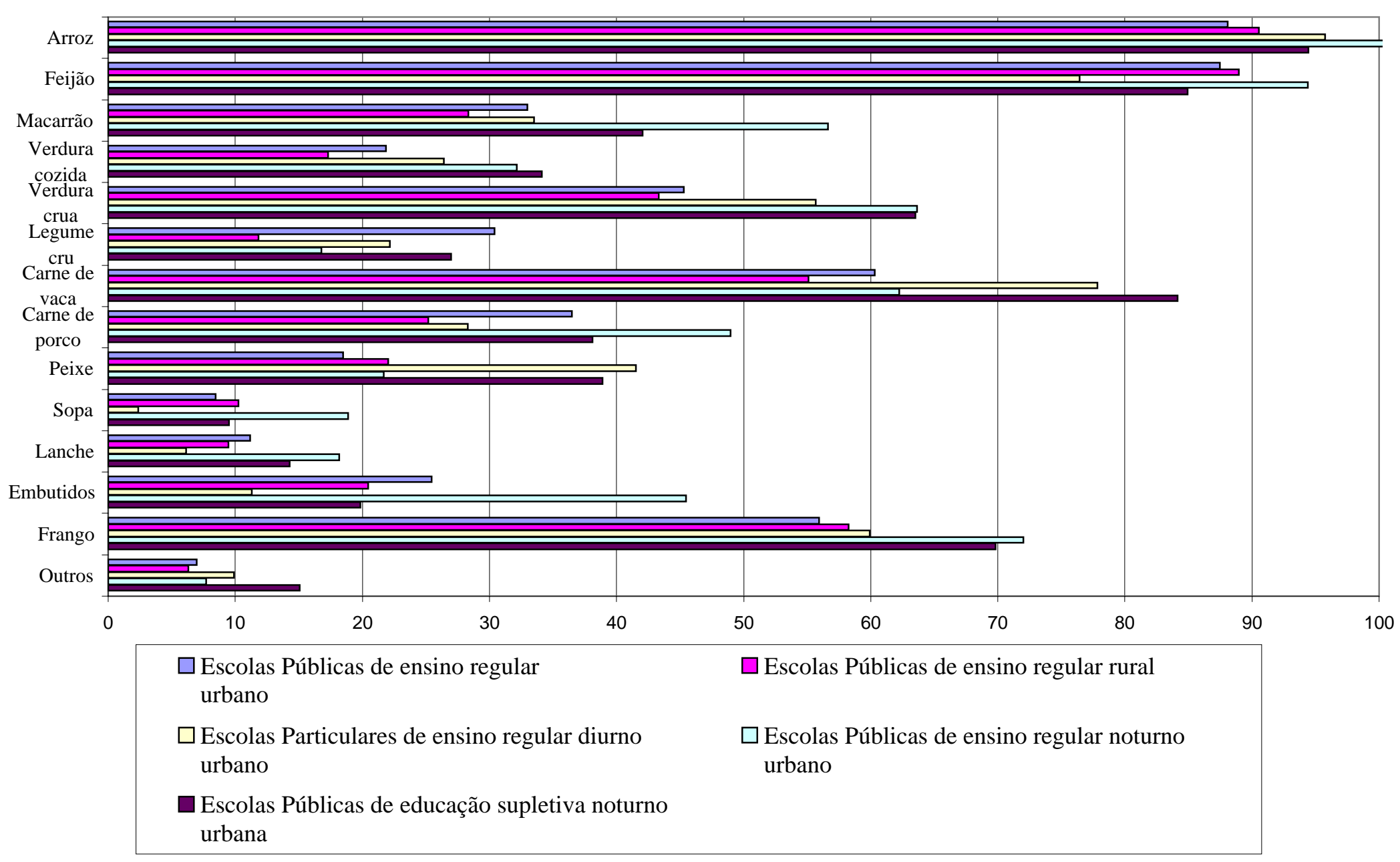

Figura 5 Alimentos ingeridos no almoço- Piracicaba (SP), 2004 


\begin{tabular}{|c|c|c|c|c|c|c|c|c|c|c|c|c|}
\hline Escolas Públicas & $\begin{array}{c}A \\
\operatorname{masc}\end{array}$ & $\begin{array}{c}A \\
\text { fem }\end{array}$ & $\begin{array}{c}\mathrm{A} \\
\text { total }\end{array}$ & $\begin{array}{c}\mathrm{B} \\
\operatorname{masc}\end{array}$ & $\begin{array}{c}B \\
\text { fem }\end{array}$ & $\begin{array}{c}\mathrm{B} \\
\text { total }\end{array}$ & $\begin{array}{c}\mathrm{C} \\
\operatorname{masc}\end{array}$ & $\begin{array}{c}\mathrm{C} \\
\text { fem }\end{array}$ & $\begin{array}{c}\mathrm{C} \\
\text { total }\end{array}$ & $\begin{array}{l}\text { Rural } \\
\text { masc }\end{array}$ & $\begin{array}{l}\text { Rural } \\
\text { fem }\end{array}$ & $\begin{array}{l}\text { Rural } \\
\text { total }\end{array}$ \\
\hline carne bovina & $62,74 \%$ & $64,84 \%$ & $63,83 \%$ & $76,47 \%$ & $67,57 \%$ & $81,93 \%$ & $75,76 \%$ & $82,73 \%$ & $68,89 \%$ & $66,66 \%$ & $60,86 \%$ & $60,86 \%$ \\
\hline carne de frango & $38,56 \%$ & $56,36 \%$ & $47,79 \%$ & $67,32 \%$ & $67,12 \%$ & $67,22 \%$ & $53,54 \%$ & $73,84 \%$ & $64,11 \%$ & $51,72 \%$ & $77,19 \%$ & $64,34 \%$ \\
\hline carne de porco & $29,41 \%$ & $83,03 \%$ & $57,23 \%$ & $37,25 \%$ & $38,38 \%$ & $37,79 \%$ & $35,35 \%$ & $28,18 \%$ & $31,57 \%$ & $22,41 \%$ & $33,33 \%$ & $27,82 \%$ \\
\hline peixes & $13,07 \%$ & $13,33 \%$ & $13,20 \%$ & $21,57 \%$ & $17,81 \%$ & $19,73 \%$ & $23,23 \%$ & $26,36 \%$ & $24,88 \%$ & $20,68 \%$ & $28,07 \%$ & $24,34 \%$ \\
\hline embutidos & $24,18 \%$ & $27,27 \%$ & $25,78 \%$ & $27,45 \%$ & $50 \%$ & $30,76 \%$ & $25,25 \%$ & $20,91 \%$ & $22,96 \%$ & $12,06 \%$ & $33,33 \%$ & $22,60 \%$ \\
\hline Escolas Particulares & $\alpha$ & $\alpha$ & $\alpha$ & $\beta$ & $\beta$ & $\beta$ & $x$ & $x$ & $x$ & & & \\
\hline carne bovina & $83,33 \%$ & $63,83 \%$ & $74,76 \%$ & $77,14 \%$ & $72,73 \%$ & $75,43 \%$ & $88 \%$ & $86,96 \%$ & $87,50 \%$ & & & \\
\hline carne de frango & $51,67 \%$ & $63,83 \%$ & $57 \%$ & $62,86 \%$ & $45,45 \%$ & $56,14 \%$ & $64 \%$ & $81,82 \%$ & $70,83 \%$ & & & \\
\hline carne de porco & $31,67 \%$ & $21,28 \%$ & $27,18 \%$ & $25,71 \%$ & $18,18 \%$ & $22,80 \%$ & $40 \%$ & $34,78 \%$ & $37,50 \%$ & & & \\
\hline peixes & $26,67 \%$ & $27,65 \%$ & $25,23 \%$ & $25,71 \%$ & $36,36 \%$ & $29,82 \%$ & $36 \%$ & $26,09 \%$ & $35,41 \%$ & & & \\
\hline embutidos & $6,67 \%$ & $8,51 \%$ & $7,47 \%$ & $11,43 \%$ & $18,18 \%$ & $14,03 \%$ & $16 \%$ & $18,16 \%$ & $16,66 \%$ & & & \\
\hline & \multirow{2}{*}{\multicolumn{12}{|c|}{$\begin{array}{l}\text { fonte mais consumida } \\
\text { fonte menos consumida }\end{array}$}} \\
\hline & & & & & & & & & & & & \\
\hline
\end{tabular}

Quadro 7 Percentuais de ingestão de principais fontes proteicas de origem animal entre alunos do período diumo, no almoço Piracicaba (SP), 2004 
Tabela 3. Comparativa entre alunos de escolas públicas e particulares, de zona urbana e rural, quanto aos alimentos selecionados para 0 ALMOçO. Piracicaba (SP), 2004

\begin{tabular}{|c|c|c|c|c|c|c|c|c|c|c|c|c|c|c|c|c|c|c|c|c|c|c|c|c|c|c|c|c|c|c|}
\hline \multirow[b]{2}{*}{ Alimentos } & \multicolumn{6}{|c|}{$\begin{array}{l}\text { Escolas Públicas de ensino regular } \\
\text { urbano }\end{array}$} & \multicolumn{6}{|c|}{ Escolas Públicas de ensino regular rural } & \multicolumn{6}{|c|}{$\begin{array}{l}\text { Escolas Particulares de ensino regular diurno } \\
\text { urbano }\end{array}$} & \multicolumn{6}{|c|}{$\begin{array}{l}\text { Escolas Públicas de ensino regular noturno } \\
\text { urbano }\end{array}$} & \multicolumn{6}{|c|}{$\begin{array}{l}\text { Escolas Públicas de educacẵo supletiva } \\
\text { noturno urbana }\end{array}$} \\
\hline & Masc & $\%$ & Fem & $\%$ & Total & $\%$ & Masc & $\%$ & Fem & $\%$ & Total & $\%$ & Masc & $\%$ & Fem & $\%$ & Total & $\%$ & Masc & $\%$ & Fem & $\%$ & Total & $\%$ & Masc & $\%$ & Fem & $\%$ & Total & $\%$ \\
\hline Arroz & 349 & $90,65^{*}$ & 361 & $85,75^{*}$ & 710 & $88,09^{*}$ & 58 & $92,06^{*}$ & 57 & $89,06^{*}$ & 115 & $90,55^{*}$ & 119 & $99,17^{*}$ & 84 & $91,30^{*}$ & 203 & $95,75^{*}$ & 68 & $95,77^{*}$ & 81 & $112,50^{*}$ & 149 & $104,20^{*}$ & 54 & $93,10^{*}$ & 65 & $95,59^{*}$ & 119 & $94,44^{*}$ \\
\hline Feijão & 344 & $89,35^{*}$ & 361 & $85,75^{*}$ & 705 & $87,47^{*}$ & 58 & $92,06^{*}$ & 55 & $85,94^{*}$ & 113 & $88,98^{*}$ & 104 & $86,67^{*}$ & 58 & $63,04^{*}$ & 162 & $76,42^{*}$ & 65 & $91,55^{*}$ & 70 & $97,22^{*}$ & 135 & $94,41^{*}$ & 50 & $86,21^{*}$ & 57 & $83,82^{*}$ & 107 & $84,92^{*}$ \\
\hline Macarrão & 141 & 36,62 & 125 & 29,69 & 266 & 33 & 15 & 23,81 & 21 & 32,81 & 36 & 28,35 & 40 & 33,33 & 31 & 33,70 & 71 & 33,49 & 39 & $54,93^{*}$ & 42 & 58,33 & 81 & 56,64 & 21 & 36,21 & 32 & 47,06 & 53 & 42,06 \\
\hline Verdura cozida & 73 & 18,96 & 103 & 24,47 & 176 & 21,84 & 11 & 17,46 & 11 & 17,19 & 22 & 17,32 & 27 & 22,50 & 29 & 31,52 & 56 & 26,42 & 14 & 19,72 & 32 & 44,44 & 46 & 32,17 & 9 & 15,52 & 34 & 50,00 & 43 & 34,13 \\
\hline Verdura crua & 187 & $48,57^{*}$ & 178 & $42,28^{*}$ & 365 & $45,29^{*}$ & 27 & $42,86^{*}$ & 28 & $43,75^{*}$ & 55 & $43,31^{*}$ & 65 & $54,17^{*}$ & 53 & $57,61^{*}$ & 118 & $55,66^{*}$ & 21 & 29,58 & 70 & $97,22^{*}$ & 91 & 63,64 & 33 & $56,90^{*}$ & 47 & $69,12^{*}$ & 80 & $63,49^{*}$ \\
\hline Legume cru & 120 & 31,17 & 125 & 29,69 & 245 & 30,40 & 5 & 7,94 & 10 & 15,63 & 15 & 11,81 & 25 & 20,83 & 22 & 23,91 & 47 & 22,17 & 7 & 9,86 & 17 & 23,61 & 24 & 16,78 & 12 & 20,69 & 22 & 32,35 & 34 & 26,98 \\
\hline Carne de vaca & 271 & $70,39^{*}$ & 215 & $51,07^{*}$ & 486 & $60,30^{*}$ & 32 & $50,79^{*}$ & 38 & $59,38^{*}$ & 70 & $55,12^{*}$ & 99 & $82,50^{*}$ & 66 & $71,74^{*}$ & 165 & $77,83^{*}$ & 39 & $54,93^{*}$ & 50 & $69,44^{*}$ & 89 & $62,24^{*}$ & 47 & $81,03^{*}$ & 59 & $86,76^{*}$ & 106 & $84,13^{*}$ \\
\hline Carne de porco & 130 & 33,77 & 164 & 38,95 & 294 & 36,48 & 13 & 20,63 & 19 & 29,69 & 32 & 25,20 & 38 & 31,67 & 22 & 23,91 & 60 & 28,30 & 36 & 50,70 & 34 & 47,22 & 70 & 48,95 & 23 & 39,66 & 25 & 36,76 & 48 & 38,10 \\
\hline Peixe & 70 & 18,18 & 79 & 18,76 & 149 & 18,49 & 12 & 19,05 & 16 & 25 & 28 & 22,05 & 61 & 50,83 & 27 & 29,35 & 88 & 41,51 & 15 & 21,13 & 16 & 22,22 & 31 & 21,68 & 23 & 39,66 & 26 & 38,24 & 49 & 38,89 \\
\hline Sopa & 31 & 8,05 & 37 & 8,79 & 68 & 8,44 & 4 & 6,35 & 9 & 14,06 & 13 & 10,24 & 4 & 3,33 & 1 & 1,09 & 5 & 2,36 & 13 & 18,31 & 14 & 19,44 & 27 & 18,88 & 5 & 8,62 & 7 & 10,29 & 12 & 9,52 \\
\hline Lanche & 44 & 11,43 & 46 & 10,93 & 90 & 11,17 & 5 & 7,94 & 7 & 10,94 & 12 & 9,45 & 10 & 8,33 & 3 & 3,26 & 13 & 6,13 & 11 & 15,49 & 15 & 20,83 & 26 & 18,18 & 12 & 20,69 & 6 & 8,82 & 18 & 14,29 \\
\hline Embutidos & 97 & 25,19 & 108 & 25,65 & 205 & 25,43 & 7 & 11,11 & 19 & 29,69 & 26 & 20,47 & 12 & 10 & 12 & 13,04 & 24 & 11,32 & 30 & 42,25 & 35 & 48,61 & 65 & 45,45 & 13 & 22,41 & 12 & 17,65 & 25 & 19,84 \\
\hline Frango & 198 & $51,43^{*}$ & 253 & $60,10^{*}$ & 451 & $55,96^{*}$ & 30 & $47,62^{*}$ & 44 & $68,75^{*}$ & 74 & $58,27^{*}$ & 69 & $57,50^{*}$ & 58 & $63,04^{*}$ & 127 & $59,91^{*}$ & 47 & $66,20^{*}$ & 56 & $77,78^{*}$ & 103 & $72,03^{*}$ & 36 & $62,07^{*}$ & 52 & $76,47^{*}$ & 88 & $69,84^{*}$ \\
\hline Outros & 30 & 7,79 & 26 & 6,18 & 56 & 6,95 & 4 & 6,35 & 4 & 6,25 & 8 & 6,30 & 14 & 11,67 & 7 & 7,61 & 21 & 9,91 & 2 & 2,82 & 9 & 12,50 & 11 & 7,69 & 10 & 17,24 & 9 & 13,24 & 19 & 15,08 \\
\hline
\end{tabular}

* Alimentos mais escollidos 
Tabela 3A. Alimentos selecionados para o ALMOÇO por 100\% dos sujetitos de pesquisa que frequentam escolas püblicas de categoria A e particulares $\alpha$ (Zona Urbana). Piracicaba (SP), 2004

\begin{tabular}{|c|c|c|c|c|c|c|c|c|c|c|c|c|c|c|c|c|c|c|c|c|c|c|c|c|c|}
\hline \multirow[b]{2}{*}{ Alimentos } & \multicolumn{4}{|c|}{ EPU regular diurno } & \multicolumn{4}{|c|}{ EPU regular noturno } & \multicolumn{4}{|c|}{ EPU educacẵos sppletiva } & & \multicolumn{4}{|c|}{ Total Escolas Päbicicas } & \multicolumn{4}{|c|}{ EPA regular diurno } & \multicolumn{4}{|c|}{ TOTAL GERAL } \\
\hline & $\begin{array}{l}1533 \\
\text { masc Masc }\end{array}$ & $\%$ & $\begin{array}{l}165 \\
\text { fem }\end{array}$ & $\%$ & 丝3 Masc & $\%$ & $\underset{\text { fem }}{17}$ Fem & $\%$ & $\underset{\text { masc Masc }}{19}$ & $\%$ & $\begin{array}{l}{ }_{\text {fem }}^{34} \text { Fen } \\
\text { (n) }\end{array}$ & $\%$ & & $\begin{array}{l}175 \mathrm{Masc} \\
\text { macs }\end{array}$ & $\%$ & $\underset{\mathrm{fem}}{216 \mathrm{Fem}}$ & $\%$ & $\begin{array}{c}{ }_{\text {masc }}^{60} \text { Masc } \\
\text { mats }\end{array}$ & $\%$ & $\underset{\text { fem }}{47}$ Fem & $\%$ & 橎asc Masc & $\%$ & $\begin{array}{l}263 \text { Fem } \\
\text { fem }\end{array}$ & $\%$ \\
\hline Arroz & 131 & $85,62^{*}$ & 94 & $56,97 *$ & 22 & $95,65^{*}$ & 17 & $100^{*}$ & 15 & $78,95^{*}$ & 29 & 85,2 & & 168 & $9^{96^{*}}$ & 140 & $64,81^{*}$ & 60 & $100^{*}$ & 42 & $89,36^{*}$ & 228 & $97,02^{*}$ & 182 & $69,20^{*}$ \\
\hline Feijãa & 117 & $76,47^{*}$ & 135 & $81,2^{*}$ & 22 & $95,5^{*}$ & 17 & $100^{*}$ & 15 & $78,95^{*}$ & 27 & 79,4 & & 154 & $88^{*}$ & 179 & $82,87^{*}$ & 51 & $85^{*}$ & 30 & $63,83^{*}$ & 205 & $87,23^{*}$ & 209 & $79,47^{*}$ \\
\hline Macarăa & 48 & 31,37 & 47 & 28,48 & 10 & $43,48^{*}$ & 10 & $58,2^{*}$ & 5 & 26,32 & 11 & 32, & & 63 & 36,00 & 68 & 31,48 & 25 & 41,67 & 15 & 31,91 & 88 & 37,45 & 83 & 31,56 \\
\hline Verdura cozida & 21 & 13,73 & 34 & 20,61 & 6 & 26,09 & 7 & 41,18 & 4 & 21,05 & 17 & 50 & & 31 & 17,71 & 58 & 26,85 & 17 & 28,33 & 17 & 36,17 & 48 & 20,43 & 75 & 28,52 \\
\hline Verdurar cna & 58 & $37,91^{*}$ & 93 & $56,36^{*}$ & 3 & 13,04 & 7 & 41,18 & 10 & $52,63^{*}$ & 22 & 64,7 & & 71 & $40,57^{*}$ & 122 & 56,48 & 29 & $48,33^{*}$ & 30 & $63,83^{*}$ & 100 & $42,55^{*}$ & 152 & 57,79 \\
\hline Legume сти & 19 & 12,42 & 25 & 15,15 & 1 & 4,35 & 6 & 35,29 & 2 & 10,53 & 8 & 23,5 & & 22 & 13 & 39 & 18,06 & 14 & 23,33 & 8 & 17,02 & 36 & 15,32 & 47 & 17,87 \\
\hline Came de vaca & 96 & $62,75^{*}$ & 107 & $64,85^{*}$ & 10 & $43,48^{*}$ & 8 & $47,06^{*}$ & 12 & $63,16^{*}$ & 26 & 76,4 & & 118 & $67,43^{*}$ & 141 & $65,28^{*}$ & 50 & $83,33^{*}$ & 30 & $63,83^{*}$ & 168 & $71,49 *$ & 171 & $65,02^{*}$ \\
\hline Carne de porco & 45 & 29,41 & 137 & $83,03^{*}$ & 13 & $5,6,2^{*}$ & 7 & 41,18 & 7 & 36,84 & 11 & 32, & & 65 & 37,14 & 155 & $71,76^{*}$ & 19 & 31,67 & 10 & 21,28 & 84 & 35,74 & 165 & $62,74^{*}$ \\
\hline Peixe & 20 & 13,07 & 22 & 13,33 & 4 & 17,39 & 4 & 23,53 & 7 & 36,84 & 15 & 44, & & 31 & 17,71 & 41 & 18,98 & 16 & 26,67 & 13 & 27,66 & 47 & 20 & 54 & 20,53 \\
\hline Sopa & 8 & 5,23 & 11 & 6,67 & 6 & 26,09 & 6 & 35,29 & 2 & 10,53 & 5 & 14, & & 16 & 9,14 & 22 & 10,19 & 1 & 1,67 & 1 & 2,13 & 17 & 7,23 & 23 & 8,75 \\
\hline Lanche & 13 & 8,50 & 17 & 10,30 & 5 & 21,74 & 4 & 23,53 & 5 & 45,45 & 3 & 8,8 & & 23 & 13,14 & 24 & ${ }_{11,11}$ & 3 & 5,00 & 2 & 4,26 & 26 & 11,06 & 26 & 9,89 \\
\hline Embutidos & 37 & 24,18 & 45 & 27,27 & 7 & 30,43 & 7 & 41,18 & 5 & 45,45 & 5 & 14, & & 49 & 28,00 & 57 & 26,39 & 4 & 6,67 & 4 & 8,51 & 53 & 22,55 & 61 & 23,19 \\
\hline Frango & 59 & $38,56^{*}$ & 93 & $56,36^{*}$ & 16 & $69,57 *$ & 12 & $70,59 *$ & 9 & $81,82^{*}$ & 19 & 55,8 & & 84 & $48^{*}$ & 124 & $57,4^{*}$ & 31 & $51,67 *$ & 30 & $63,83^{*}$ & 115 & $48,94^{*}$ & 154 & $58,56^{*}$ \\
\hline Outros & 8 & 5,23 & 12 & 7,27 & 2 & 8,70 & 3 & 17,65 & 1 & 9,09 & 4 & 11, & & 11 & 6,29 & 19 & 8,80 & 4 & 6,67 & 4 & 8,51 & 15 & 6,38 & 23 & 8,75 \\
\hline
\end{tabular}


Tabela 3B. Alimentos selecionados para o ALMOÇO por 100\% dos sujeitos de pesquisa que frequentam escolas püblicas de categoria Be particulares $\beta$ (Zona Urbana). Piracicaba (SP), 2004

\begin{tabular}{|c|c|c|c|c|c|c|c|c|c|c|c|c|c|c|c|c|c|c|c|c|c|c|c|c|}
\hline \multirow[b]{2}{*}{$\begin{array}{l}\text { Alimentos } \\
\end{array}$} & \multicolumn{4}{|c|}{ EPU regular diurno } & \multicolumn{4}{|c|}{ EPU regular noturno } & \multicolumn{4}{|c|}{ EPU educacẵos sppletiva } & \multicolumn{4}{|c|}{ Total Escolas Públicas } & \multicolumn{4}{|c|}{ EPA regular diurro } & \multicolumn{4}{|c|}{ TOTAL GERAL } \\
\hline & $\begin{array}{l}153 \\
\text { masc }\end{array}$ & $\%$ & $\begin{array}{l}146 \\
\text { fem }\end{array}$ & $\%$ & $\begin{array}{l}3_{\text {masc }}^{30} \text { Masc } \\
\text { a }\end{array}$ & $\%$ & $\begin{array}{l}40 \\
\text { fem }\end{array}$ & $\%$ & $\begin{array}{l}18 \\
\text { masc } \\
\text { masc }\end{array}$ & $\%$ & $\underset{\text { fem }}{21} \mathrm{Fem}$ & $\%$ & $\begin{array}{l}201 \\
\text { masc Masc }\end{array}$ & $\%$ & $\begin{array}{l}207 \\
\text { fem Fem }\end{array}$ & $\%$ & $\begin{array}{l}\frac{35}{\text { masc Masc }} \\
\text { mas }\end{array}$ & $\%$ & $\begin{array}{l}22 \\
\text { fem Fem }\end{array}$ & $\%$ & $\begin{array}{l}236 \text { Masc } \\
\text { masc }\end{array}$ & $\%$ & $\begin{array}{l}229 \\
\text { fem Fem }\end{array}$ & $\%$ \\
\hline Arroz & 153 & ${ }^{100^{*}}$ & 146 & $100^{*}$ & 28 & $93,33^{*}$ & 40 & $100^{*}$ & 15 & $83,33^{*}$ & 18 & $85,71^{*}$ & 196 & $97,51^{*}$ & 204 & $98,55^{*}$ & 35 & $100^{*}$ & 22 & $100^{*}$ & 231 & $97,8^{* *}$ & 226 & $98,69^{*}$ \\
\hline Fejijà & 153 & ${ }^{100^{*}}$ & 146 & $100^{*}$ & 25 & $83,33^{*}$ & 40 & $100^{*}$ & 14 & $77,78^{*}$ & 18 & $85,7^{*}$ & 192 & $95,52^{*}$ & 204 & $98,55^{*}$ & 32 & $91,3^{*}$ & 14 & $63,64^{*}$ & 224 & $94,92^{*}$ & 218 & $95,20^{*}$ \\
\hline Macarão & 56 & 36,60 & 47 & 32,19 & 19 & $63,33^{*}$ & 24 & $60^{*}$ & 7 & 38,89* & 9 & 42,86 & 82 & 40,80 & 80 & 38,65 & 6 & 17,14 & 4 & 18,18 & 88 & 37,29 & 84 & 36,68 \\
\hline Verdura cozida & 34 & 22,22 & 38 & 26,03 & 5 & 16,67 & 23 & 57,50 & 4 & 22,22 & 11 & 52,38 & 43 & 21,39 & 72 & 34,78 & 9 & 25,71 & 6 & 27,27 & 52 & 22,03 & 78 & 34,06 \\
\hline Verdura crua & 84 & $54,90^{*}$ & 101 & $69,18^{*}$ & 10 & 33,33 & ${ }^{24}$ & $60^{*}$ & ${ }^{11}$ & $6,11^{*}$ & 14 & $66,67^{*}$ & 105 & $52,24^{*}$ & 139 & $67,15^{*}$ & 24 & $68,57^{*}$ & 12 & $54,55^{*}$ & 129 & $54,66^{*}$ & 151 & $65,94^{*}$ \\
\hline Legume cru & 32 & 20,92 & 30 & 20,55 & 3 & 10 & 8 & 20 & 3 & 16,67 & 5 & 23,81 & 38 & 18,91 & 43 & 20,77 & 4 & ${ }_{11,43}$ & 6 & 27,27 & 42 & 17,80 & 49 & 21,40 \\
\hline Came de vaca & 117 & ${ }^{76,47^{*}}$ & 128 & $87,67^{*}$ & 18 & $60^{*}$ & 35 & $87,50^{*}$ & 13 & $72,22^{*}$ & 13 & $61,90^{*}$ & 148 & $73,63^{*}$ & 176 & $85,02^{*}$ & 27 & $77,14^{*}$ & 16 & $72,3^{*}$ & 175 & $74,15^{*}$ & 192 & $83,84^{*}$ \\
\hline Carne de porco & 57 & 37,25 & 56 & 38,36 & 15 & 50 & ${ }^{21}$ & 52,50 & 6 & 33,33 & ${ }^{6}$ & 28,57 & 78 & 38,81 & 83 & 40,10 & 9 & 25,71 & 4 & 18,18 & 87 & 36,86 & 87 & 37,99 \\
\hline Peixe & 33 & 21,57 & 26 & 17,81 & 8 & 26,67 & 11 & 27,50 & 7 & 38,89 & 5 & ${ }^{23,81}$ & 48 & 23,88 & 42 & 20,29 & 9 & 25,71 & 8 & 36,36 & 57 & 24,15 & 50 & $\begin{array}{r}21,83 \\
\end{array}$ \\
\hline Sopa & 11 & 7,19 & ${ }_{11}$ & 7,53 & 6 & 20 & 7 & 17,50 & 2 & 11,11 & $2^{2}$ & 9,52 & 19 & 9,45 & 20 & 9,66 & 2 & 5,71 & 0 & 0,00 & 21 & 8,90 & 20 & 8,73 \\
\hline Lanche & 20 & 13,07 & 18 & 12,33 & 5 & 16,67 & ${ }_{11}$ & 27,50 & 4 & 22,22 & 3 & $\begin{array}{r}14,29 \\
\end{array}$ & 29 & 14,43 & 32 & 15,46 & 4 & 11,43 & 1 & 4,55 & 33 & 13,98 & 33 & 14,41 \\
\hline Embutidos & 42 & 27,45 & 50 & 34,25 & 13 & 43,33 & 20 & 50 & 4 & 22,22 & 3 & $\begin{array}{r}14,29 \\
\end{array}$ & 59 & 29,35 & 73 & 35,27 & 4 & 11,43 & 4 & 18,18 & 63 & 26,69 & 77 & 33,62 \\
\hline Frango & 103 & $67,32^{*}$ & 98 & $67,12^{*}$ & 17 & $56,66^{*}$ & 35 & $87,50^{*}$ & 11 & $61,11^{*}$ & 15 & $71,3^{*}$ & 131 & $65,1^{*}$ & 148 & $71,50^{*}$ & 22 & $62,86^{*}$ & 10 & $45,45^{*}$ & 153 & $64,83^{*}$ & 158 & $69^{*}$ \\
\hline Ourros & 7 & 4,58 & 12 & 8,22 & 0 & 0,00 & 4 & 10 & 2 & 11,11 & 3 & 14,29 & 9 & 4,48 & 19 & 9,18 & 3 & 8,57 & 1 & 4,55 & 12 & 5,08 & 20 & 8,73 \\
\hline
\end{tabular}


Tabela 3C. Alimentos selecionados para o ALMOÇO por 100\% dos sujeitos de pesquisa que frequentam escolas püblicas de categoria C e particulares $x$ (Zona Urbana). Piracicaba (SP), 2004

\begin{tabular}{|c|c|c|c|c|c|c|c|c|c|c|c|c|c|c|c|c|c|c|c|c|c|c|c|c|c|}
\hline \multirow[b]{2}{*}{ Alimentos } & \multicolumn{4}{|c|}{ EPU regular diurno } & \multicolumn{4}{|c|}{ EPU regular noturno } & \multicolumn{4}{|c|}{ EPU educaşăo supletiva } & \multicolumn{5}{|c|}{ Total Escolas Püblicas } & \multicolumn{4}{|c|}{ EPA regular diurno } & \multicolumn{4}{|c|}{ TOTAL GERAL } \\
\hline & $\begin{array}{l}99 \\
\text { masc }\end{array}$ & $\% \quad \begin{array}{c}110 \\
\text { fem }\end{array}$ & $\begin{array}{llll}0 & \text { Fem } \\
n\end{array}$ & $\%$ & $\begin{array}{c}18 \\
\text { masc } \\
\text { masc }\end{array}$ & $\%$ & $\begin{array}{l}15 \\
\text { fem }\end{array}$ & $\%$ & $\begin{array}{c}17 \\
\text { masc }\end{array}$ & $\%$ & $\begin{array}{l}\text { fem } \\
\text { fem }\end{array}$ & $\%$ & $\begin{array}{l}134 \\
\text { masc Masc }\end{array}$ & $\%$ & $\begin{array}{l}{ }_{\text {fem }}^{136} \mathrm{Fe} \\
-\end{array}$ & $\mathrm{m}$ & $\%$ & $\begin{array}{l}25 \\
\text { masc } \\
\text { masc }\end{array}$ & $\% \underset{\text { fem }}{23}$ & Fem & $\%$ & $\begin{array}{l}1599 \text { Masc } \\
\text { masc }\end{array}$ & $\%$ & $\begin{array}{l}\text { Ifem } \\
\text { fem } \\
\text { fem }\end{array}$ & $\%$ \\
\hline Arroz & 99 & $100^{*}$ & 110 & $100^{*}$ & 18 & $100^{*}$ & 14 & ${ }^{93,33^{*}}$ & 17 & $100^{*}$ & ${ }^{11}$ & $100^{*}$ & 134 & $100^{*}$ & 13 & $35 \quad 99$ & $9,26^{*}$ & 24 & $96^{*}$ & 20 & $86,96^{*}$ & 158 & $99,37^{*}$ & 155 & $97,48^{*}$ \\
\hline Feijāa & 97 & $97,98^{*}$ & 110 & $100^{*}$ & 18 & $100^{*}$ & 13 & $86,67^{*}$ & 15 & $88,24^{*}$ & 5 & $23,81^{*}$ & 130 & $97,01^{*}$ & ${ }_{12}$ & $28 \quad 94$ & 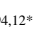 & 21 & $84{ }^{8 *}$ & 14 & $60,87^{*}$ & 151 & $94,97^{*}$ & 142 & ${ }^{89,31^{*}}$ \\
\hline Macarăa & 48 & 48,48 & 43 & 39,09 & 10 & $55,56^{*}$ & 8 & $53,33^{*}$ & 4 & 23,53 & 2 & 9,52 & 62 & 46,27 & 5 & 3 & 38,97 & 9 & 36 & 12 & $52,17^{*}$ & 71 & 44,65 & 65 & 40,88 \\
\hline Verdura cozida & 24 & 24,24 & 41 & 37,27 & 3 & 16,67 & 2 & 13,33 & 3 & 17,65 & 5 & $23,81^{*}$ & 30 & 22,39 & ${ }^{4}$ & 8 & 35,29 & 1 & 4 & 6 & 26,09 & 31 & 19,50 & 54 & 33,96 \\
\hline Verdura crua & 59 & $59,60^{*}$ & 69 & $62,73^{*}$ & 8 & 4,44 & 9 & $60^{*}$ & 8 & $47,06^{*}$ & 7 & $33,33^{*}$ & 75 & $55,97 *$ & 8 & 562 & $2,50^{*}$ & 12 & $48^{*}$ & 11 & 47,83 & 87 & $54,72^{*}$ & 96 & $60,33^{*}$ \\
\hline Legume cru & 21 & 21,21 & 24 & 21,82 & 3 & 16,67 & 1 & 6,67 & 1 & 5,88 & 5 & $23,81^{*}$ & 25 & 18,66 & 3 & 0 & 22,06 & 7 & 28 & 8 & 34,78 & 32 & 20,13 & 38 & 23,90 \\
\hline Carne de vaca & 75 & $75,76^{*}$ & 69 & $62,73^{*}$ & 11 & $61,11^{*}$ & 7 & 46,67 & 11 & $64,71^{*}$ & 7 & $33,33^{*}$ & 97 & $72,39 *$ & 8 & 3 & : & 22 & $88^{*}$ & 20 & $86,96^{*}$ & 119 & $74,84^{*}$ & 103 & $64,78^{*}$ \\
\hline Came de porco & 35 & 35,35 & 31 & 28,18 & 8 & 44,44 & 6 & 40 & 6 & 35,29 & 3 & 14,29 & 49 & 36,57 & ${ }^{4}$ & 10 & 29,41 & 10 & 40 & 8 & 34,78 & 59 & 37,11 & 48 & 30,19 \\
\hline Peixe & 23 & 23,23 & 29 & 26,36 & 3 & 16,67 & 1 & 6,67 & 4 & 23,53 & 3 & 14,29 & 30 & 22,39 & 3 & 3 & 24,26 & 9 & 36 & 6 & 26,09 & 39 & 24,53 & 39 & 24,53 \\
\hline Sopa & 13 & 13,13 & 18 & 16,36 & 1 & 5,56 & 2 & 13,33 & 1 & 5,88 & 2 & 9,52 & 15 & 11,19 & 2 & 2 & 16,18 & 1 & 4 & 0 & 0,00 & 16 & 10,06 & 22 & 13,84 \\
\hline Lanche & 14 & 14,14 & 13 & 11,82 & 1 & 5,56 & 0 & 0,00 & 1 & 5,88 & 1 & 4,76 & 16 & 11,94 & 1 & 4 & 10,29 & 3 & 12 & 0 & 0,00 & 19 & 11,95 & 14 & 8,81 \\
\hline Emburidos & 25 & 25,25 & 23 & 20,91 & 10 & $55,56^{*}$ & 8 & $53,33^{*}$ & 3 & 17,65 & 0 & 0,00 & 38 & 28,36 & 3 & 1 & 22,79 & 4 & 16 & 4 & 18,18 & 42 & 26,42 & 35 & 22,01 \\
\hline Frango & 53 & $53,54^{*}$ & 81 & $73,64^{*}$ & 14 & $77,78^{*}$ & 9 & $60^{*}$ & 11 & $64,71^{*}$ & 8 & $38,10^{*}$ & 78 & $58,21^{*}$ & 9 & 8 & $2,06^{*}$ & 16 & 64* & 18 & $81,2^{*}$ & 94 & $59,12^{*}$ & 116 & $72,96^{*}$ \\
\hline Ouros & 14 & 14,14 & 6 & 5,45 & 0 & 0,00 & ${ }^{2}$ & 13,33 & 0 & 0,00 & 0 & 0,00 & 14 & 10,45 & & 8 & 5,88 & 7 & 28 & 2 & 9,09 & 21 & 13,21 & 10 & 6,29 \\
\hline
\end{tabular}




\subsubsection{Quanto ao intervalo entre o almoço e o jantar}

É grande o consumo de alimentos por nossos estudantes no intervalo entre o almoço e jantar, como se observa, claramente, na Figura 6.

\subsubsection{Comparando-se o consumo em zona urbana e rural}

Em linhas gerais, na zona urbana foram apontados como os cinco alimentos preferidos por alunos da rede regular de ensino, no referido intervalo:

Masculino

$1^{\circ}$ Bolachas $\quad 65,45 \%$

$2^{\circ}$ Frutas $\quad 35,96 \%$

$3^{\circ}$ Leite $\quad 35,67 \%$

$4^{\circ}$ Lanche $\quad 32,02 \%$

$5^{\circ}$ Bolo $\quad 31,46 \%$
Feminino

$1^{\circ}$ Bolachas $\quad 55,32 \%$

$2^{\circ}$ Doces $\quad 48,14 \%$

$3^{\circ}$ Frutas $\quad 42,82 \%$

$4^{\circ}$ Bolo 40,96\%

$5^{\circ}$ Lanche $\quad 37,77 \%$

Para o sexo masculino foi verificado destaque na ingestão de bolachas e, para beber, leite.

Na zona rural, as preferências, na mesma modalidade de ensino, foram:

Masculino

Feminino

$1^{\circ}$ Bolachas

$57,14 \%$

$1^{\circ}$ Bolachas

$77,36 \%$

$2^{\circ}$ Fruta e Bolo

$39,29 \%$

$2^{\circ}$ Fruta

$62,26 \%$

$3^{\circ}$ Suco de frutas

$35,71 \%$

$3^{\circ}$ Bolo

$58,49 \%$

$4^{\circ}$ Doces

$32,14 \%$

$4^{\circ}$ Doce

$56,60 \%$

$5^{\circ}$ Lanche e leite $\quad 30,36 \%$

$5^{\circ}$ Suco de frutas

$37,74 \%$

O destaque também é para bolachas e, na bebida, suco de frutas. 
O consumo de frutas e bolacha ocupa posição de destaque no intervalo entre o almoço e o jantar em todos os grupos de alunos em estudo, quer seja de zona urbana ou rural (Tabela 4).

O lanche tem maior expressão de consumo entre estudantes das escolas particulares e de escolas públicas da rede regular de ensino diurno, sem entretanto, ultrapassar 50,00\%. Não ocupa posição de destaque entre os alunos de zona rural, muito provavelmente pela dificuldade de acesso aos fast food, e entre os da rede de ensino público regular noturno, de zona urbana, possivelmente por questões sócio-econômicas (Tabela 4).

\subsubsection{Comparando-se por período de funcionamento das escolas de zona urbana}

Observa-se que o café é consumido com expressão apenas por alunos do período noturno, seja da rede regular de ensino (40,42\% na população masculina e 39,44\% na feminina) ou da educação supletiva (26,67\% na população masculina e, mais significativamente, 38,33\% na feminina) (Tabela 4).

Ao contrário, o lanche ganha destaque apenas entre os alunos do período diurno nas escolas públicas e particulares. Nas primeiras, 32,02\% dos alunos e 37,77\% das alunas os consomem; nas outras, 43,24\% dos alunos e 36,78\% das alunas lhes dão destaque (Tabela 4).

O consumo de salgados é mais notado entre a população masculina da rede de educação supletiva (35,56\%); não se descarta a possibilidade de se constituírem o seu jantar (Tabela 4).

Algum destaque se observa para o leite, apenas entre a população masculina de escolas públicas e particulares de ensino regular diurno (respectivamente 35,67\% e 26,13\%) e da educação supletiva (33,33\%), estes do período noturno (Tabela 4). 


\subsubsection{Comparando-se por modalidade de curso}

Observa-se que as preferências entre alunos da rede regular de ensino noturno se assemelha às dos alunos da educação supletiva do mesmo período sendo que, predominantemente, os primeiros são adolescentes e os outros adultos; pressupõe-se que há probabilidade de terem condições sócio-econômicas de vida semelhantes, que possam estar interferindo na aquisição de seus hábitos alimentares (Tabela 4).

Quanto à inclusão de suco de frutas com maior expressão na zona rural, pode ser que ocorra mais devido à maior disponibilidade de frutas do que pelo conhecimento por parte dos alunos, do melhor valor nutricional do mesmo.

Considerando-se que suco natural de frutas tem maior preço no mercado, pode-se dizer que causa estranheza o destaque de sua ingestão por alunos da educação supletiva, a maioria oriunda das camadas mais pobres da população. Em se tratando de adultos, pode ser considerada a experiência de vida desses alunos e conseqüente valorização da saúde. Por outro lado, é interessante considerar que o valor nutricional das frutas, assim como de outros alimentos, tem sido bastante comentados pela mídia.

\subsubsection{Comparando-se por sexo}

As preferências pelos alimentos são basicamente as mesmas em ambos os sexos, com algumas pequenas diferenças.

O consumo de frutas entre o almoço e o jantar, de maneira geral, é maior na população feminina, a não ser nas escolas particulares da rede regular de ensino diurno e escolas públicas de educação supletiva, noturno, quando o percentual é maior na população masculina (Tabela 4).

O consumo de doce tem maior percentual de consumo entre a população feminina, em todos os grupos de alunos em estudo, no cômputo geral, no referido intervalo (Tabela 4). Ao se analisar por categoria de escolas, encontra-se algumas situações em que o contrário acontece (alunos de escolas particulares de categoria $\alpha$, da 
Educação Supletiva em escolas de categoria B, do ensino regular noturno e educação supletiva em escolas de categoria C).

O uso do café preto só se fez presente entre os cinco itens de maior consumo entre estudantes do sexo masculino e feminino do período noturno, tanto da educação supletiva como da rede regular de ensino em zona urbana; é maior entre a população masculina da rede regular de ensino e entre a população feminina da educação supletiva. Em nenhuma categoria de escolas do diurno, foi apontado o café com destaque, seja entre os alunos do sexo masculino ou do feminino.

A ingestão de salgados entre o almoço e o jantar só ganhou destaque entre os alunos do sexo masculino da educação supletiva.

\subsubsection{Comparando-se por categoria de escolas}

Nas escolas de categoria A e $\alpha$ 93,19\% dos alunos do sexo masculino e $91,2 \%$ do sexo feminino consomem algum alimento no intervalo entre o almoço e jantar; nas escolas de categoria B e $\beta$ 91,34\% e 94,32\% e nas de categoria C e $\chi 93,08 \%$ e 94,34\% respectivamente (Tabelas $4 \mathrm{~A}, 4 \mathrm{~B}$ e $4 \mathrm{C}$ ).

Nas categorias A e $\alpha$ são consumidos em percentuais mais elevados as bolachas, doces e frutas; apesar das bebidas não estarem entre as primeiras cinco escolhas, percebe-se que é maior a ingestão de leite, seguida do café e por último pelo chá. É interessante se observar que o suco de frutas só aparece com destaque entre alunos do período noturno das escolas estaduais e algumas poucas alunas da rede particular de ensino; quanto ao suco artificial, apenas alunos do sexo masculino de escolas noturnas da rede pública, afirmam ingeri-lo entre o almoço e jantar; o chá só foi apontado com destaque entre alunos do sexo masculino da rede de ensino particular; o café só teve destaque entre alunos do período noturno.

Nas categorias B e $\beta$ o consumo de bolachas entre o café e almoço é maior que em qualquer outra (64,93\% na população masculina e 68,52\% na feminina), seguida por doces e frutas; também nesta categoria a bebida mais ingerida é o leite, seguido pelo suco de frutas, suco artificial, café e o chá. O café é apontado com destaque entre alunos 
do noturno apenas, o suco artificial somente entre alunas da rede particular de ensino e o suco de frutas natural apenas por alunos do sexo masculino da rede regular de ensino público noturno e particular, este diurno.

Nas categorias $\mathrm{C}$ e $\chi$ o maior destaque de alimento consumido entre o almoço e jantar vai para bolachas entre alunos do sexo masculino e doces entre as alunas, seguidos de frutas, bolachas e leite; o café só tem destaque entre alunos do período noturno. Somente alunas da rede particular afirmam beber suco artificial nesse intervalo; o suco natural de frutas ganha destaque entre alunos da educação supletiva e da rede particular de ensino.

No geral, observa-se que mais de 90,00\% dos alunos consomem algum alimento neste intervalo, o que é bastante positivo;que o chá é muito pouco ingerido pelos nossos estudantes; que a preferência é pelo suco natural ao artificial; que o leite vem sendo escolhido por cerca de um terço dos alunos neste intervalo e pouco menos entre os de escolas de categoria A e $\alpha$; que o café tem sido preferido por alunos do período noturno, seja da rede regular de ensino ou da educação supletiva. 


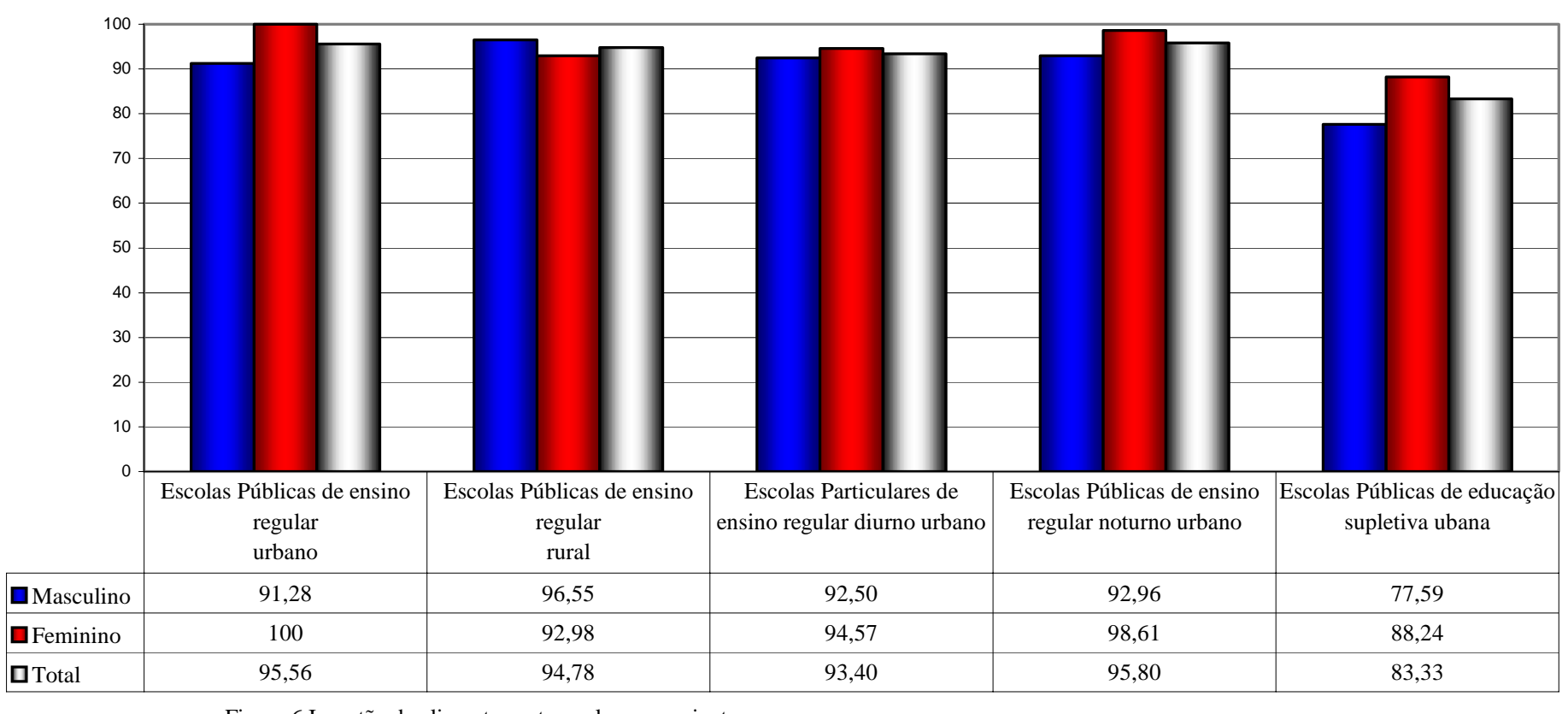




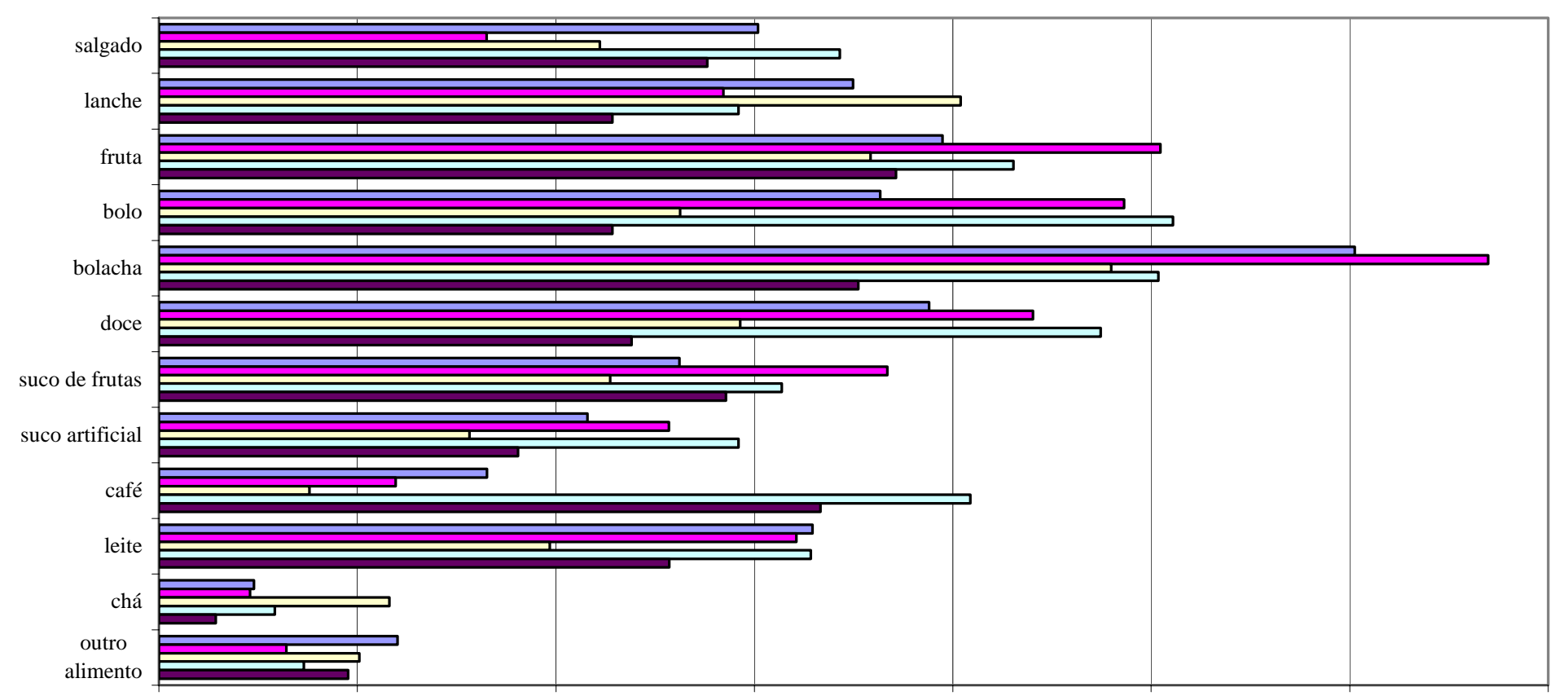

$\square$ Escolas Públicas de ensino regular

urbano

$\square$ Escolas Particulares de ensino regular diurno urbano

Escolas Públicas de ensino regular

rural

$\square$ Escolas Públicas de ensino regular noturno urbano

口Escolas Públicas de educação supletiva ubana

Figura 7 Alimentos ingeridos entre o almoço e o jantar Piracicaba (SP), 2004 


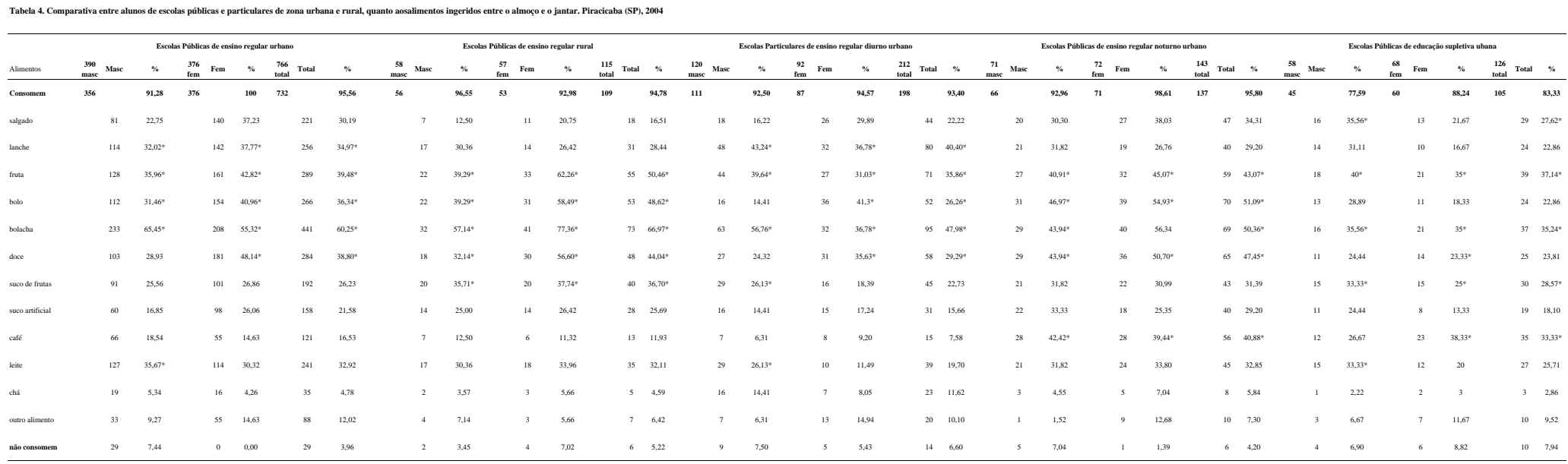


Tabela 4A. Alimentos ingeridos entre o almogoco e ojantar por alunos que frequentam escolas pubilicas de categoria A e particulares \& (Zona Urbana). Piracicaba (SP), 2004

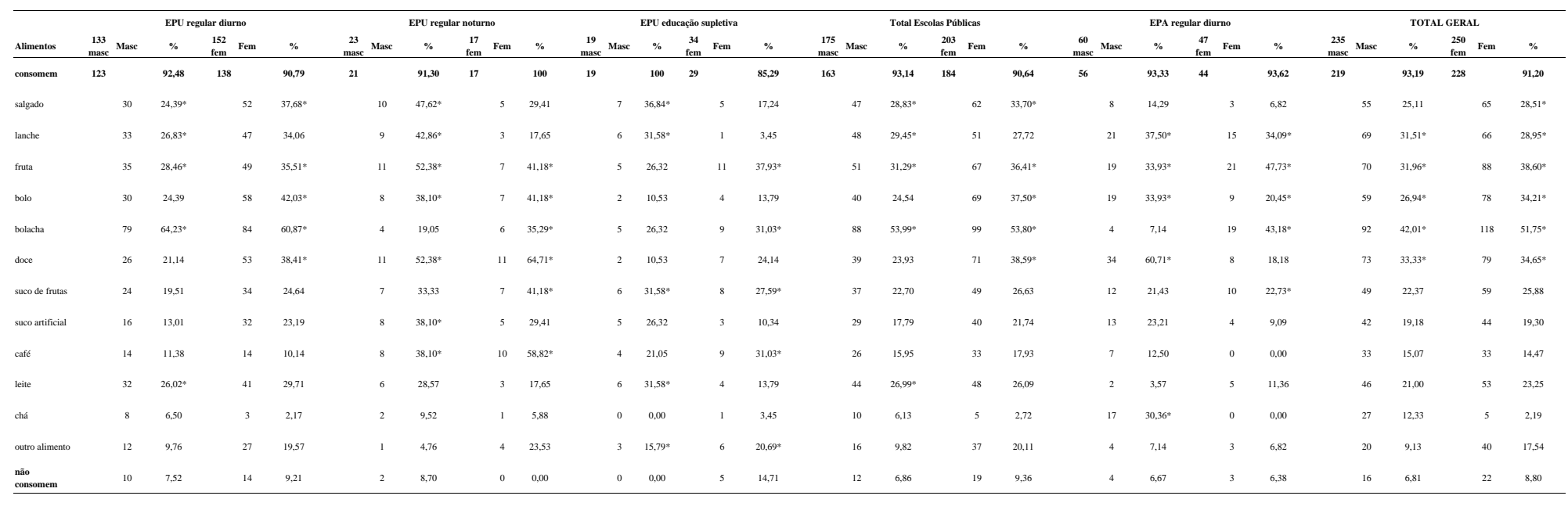


Tabela 4B. Alimentos ingeridos entre o almoço 0 jantar por concluintes do Ensino Fundamental que frequentam escolas públicas de categoria Be particulares $\beta$ (Zona Urbana). Piracicaba (SP), 2004

\begin{tabular}{|c|c|c|c|c|c|c|c|c|c|c|c|c|c|c|c|c|c|c|c|c|c|c|c|c|c|c|}
\hline \multirow[b]{2}{*}{ Alimentos } & \multicolumn{5}{|c|}{ EPU regular diurno } & \multicolumn{4}{|c|}{ EPU regular noturno } & \multicolumn{4}{|c|}{ EPU educaăăo supletiva } & \multicolumn{4}{|c|}{ Total Escolas Públicas } & \multicolumn{4}{|c|}{ EPA regular diurno } & \multicolumn{5}{|c|}{ TOTAL GERAL } \\
\hline & $\begin{array}{l}153 \text { Masc } \\
\text { masc }\end{array}$ & $\%$ & $\underbrace{146}_{f=0} \mathrm{~F}$ & & $\%$ & $\begin{array}{l}30 \text { Masc } \\
\text { masc }\end{array}$ & $\%$ & ${ }_{f e m}^{40}$ Fen & $\%$ & 13 Masc & $\%$ & $\begin{array}{cc}21 & \text { Fen } \\
& \end{array}$ & $\%$ & $\begin{array}{l}196 \text { Masc } \\
\text { masc Mas }\end{array}$ & $\%$ & ${ }_{\mathrm{fem}}^{207}$ Fen & $\%$ & $\begin{array}{l}{ }_{35}^{35} \text { Masc } \\
\text { masc }\end{array}$ & $\%$ & $\underset{f e m}{22}$ Fem & $\%$ & $\begin{array}{l}231 \text { Masc } \\
\text { masc }\end{array}$ & $\%$ & ${ }_{\mathrm{fem}}^{229}$ Fen & & $\%$ \\
\hline consomem & 143 & 93,46 & 135 & & 92,47 & 27 & 90 & 39 & 97,50 & 11 & 84,62 & 21 & 100 & 181 & 92,35 & 195 & 94,20 & 30 & 85,71 & 21 & 95,45 & 211 & 91,34 & 216 & & 4,32 \\
\hline salgado & 55 & $38,46^{*}$ & & & $42,96^{*}$ & 5 & 18,52 & ${ }_{17}$ & $43,59^{*}$ & 7 & $63,64^{*}$ & 7 & $33,33-$ & 67 & $37,02^{*}$ & 82 & $42,05^{*}$ & 6 & 20 & 4 & 19,05 & 73 & 34,60 & 86 & & $.81^{*}$ \\
\hline lanche & 51 & $35,66^{*}$ & & & $44,44^{*}$ & 9 & 33,33 & 12 & 30,77 & 6 & 54,55 & 7 & 33,33 & 66 & 36,46 & 79 & 40,51 & 15 & $50^{*}$ & 4 & 19,05 & 81 & $38,39 *$ & 83 & & 8,43 \\
\hline fruta & 48 & $33,57 *$ & s & & $45,93^{*}$ & 10 & $37,04 *$ & 21 & $53, .5^{*}$ & 10 & ${ }_{90,91 *}$ & 7 & $33,33-$ & 68 & $37,57 *$ & 90 & $46,15^{*}$ & 17 & $56,67^{*}$ & 9 & $42,86^{*}$ & 85 & $40,28^{*}$ & 99 & & .,83* \\
\hline bolo & 48 & $33,57^{*}$ & & & 39,26 & 15 & $55,5^{*}$ & 23 & $58,97^{*}$ & 7 & $63,64^{*}$ & 6 & 28,57 & 70 & $38,67^{*}$ & 82 & $42,05^{*}$ & 9 & $30^{*}$ & 4 & 19,05 & 79 & $37,4^{*}$ & 86 & & , $81^{*}$ \\
\hline bolacha & 98 & $68,53^{*}$ & 1 & & $80,74^{*}$ & 15 & $55,6^{*}$ & 28 & $71,79^{*}$ & 7 & $63,64^{*}$ & 5 & 23,81 & 120 & $66,30^{*}$ & 142 & $72,82^{*}$ & 17 & $56,67^{*}$ & 6 & $28,57^{*}$ & 137 & $64,93^{*}$ & 148 & & , 5.2* \\
\hline doce & 44 & 30,77 & & & $54,077^{*}$ & 11 & $40,74^{*}$ & 20 & $51,28^{*}$ & 7 & $63,64^{*}$ & 6 & 28,57 & 62 & 34,25 & 99 & $50,77^{*}$ & 7 & 23,33 & 5 & $23,81^{*}$ & 69 & 32,70 & 104 & & $3,15^{*}$ \\
\hline suco de frutas & 36 & 25,17 & & & 31,85 & 10 & $37,04^{*}$ & 13 & 33,33 & 6 & 54,55 & 5 & 23,81 & 52 & 28,73 & ${ }_{61}$ & 31,28 & 10 & $33,33^{*}$ & 3 & 14,29 & 62 & 29,38 & 64 & & 9,63 \\
\hline suco artificial & 25 & 17,48 & & & 27,41 & 9 & 33,33 & ${ }_{11}^{11}$ & 28,21 & 4 & 36,36 & 4 & 19,05 & 38 & 20,99 & 52 & 26,67 & 6 & 20 & 6 & $28,57 *$ & 44 & 20,85 & 58 & & 6,85 \\
\hline café & 27 & 18,88 & & & 16,30 & 13 & $48,15^{*}$ & ${ }_{17}$ & $43,59^{2 *}$ & 5 & 45,45 & ${ }_{11}^{11}$ & $52,38^{-}$ & 45 & 24,86 & 50 & 25,64 & 2 & 6,67 & 0 & 0,00 & 47 & 22,27 & 50 & & 3,15 \\
\hline lete & 54 & $37,76^{*}$ & & & 31,11 & 9 & 33,33 & 16 & 41,03 & 4 & 36,36 & 5 & 23,81 & 67 & $37,02^{*}$ & 63 & 32,31 & 7 & 23,33 & 3 & 14,29 & 74 & $35,07{ }^{*}$ & 66 & & 0,56 \\
\hline chá & 4 & 2,80 & & & 5,19 & 1 & 3,70 & 3 & 7,69 & 0 & 0,00 & 0 & 0,00 & 5 & 2,76 & ${ }_{10}^{10}$ & 5,13 & 2 & 6,67 & 1 & 4,76 & 7 & 3,32 & 11 & & 5,09 \\
\hline ourro alimento & 10 & 6,99 & & & 12,59 & 0 & 0,00 & 4 & 10,26 & 0 & 0,00 & 0 & 0,00 & 10 & 5,52 & 21 & 10,77 & 3 & 10 & 7 & $33,33^{*}$ & 13 & 6,16 & 28 & & 2,96 \\
\hline não consomem & 10 & 6,54 & & & 7,53 & 3 & 10 & 1 & 2,50 & 2 & 15,38 & 0 & 0,00 & 15 & 7,65 & 12 & 5,80 & 5 & 14,29 & 1 & 4,55 & 20 & 8,66 & 13 & & 5,68 \\
\hline
\end{tabular}


Tabela AC. Alimentos ingeridos por concluines do ensino fundamental que frequentam escolas pübicicas de categoria Ce particulares $x$. Piracicaba(SP), 204

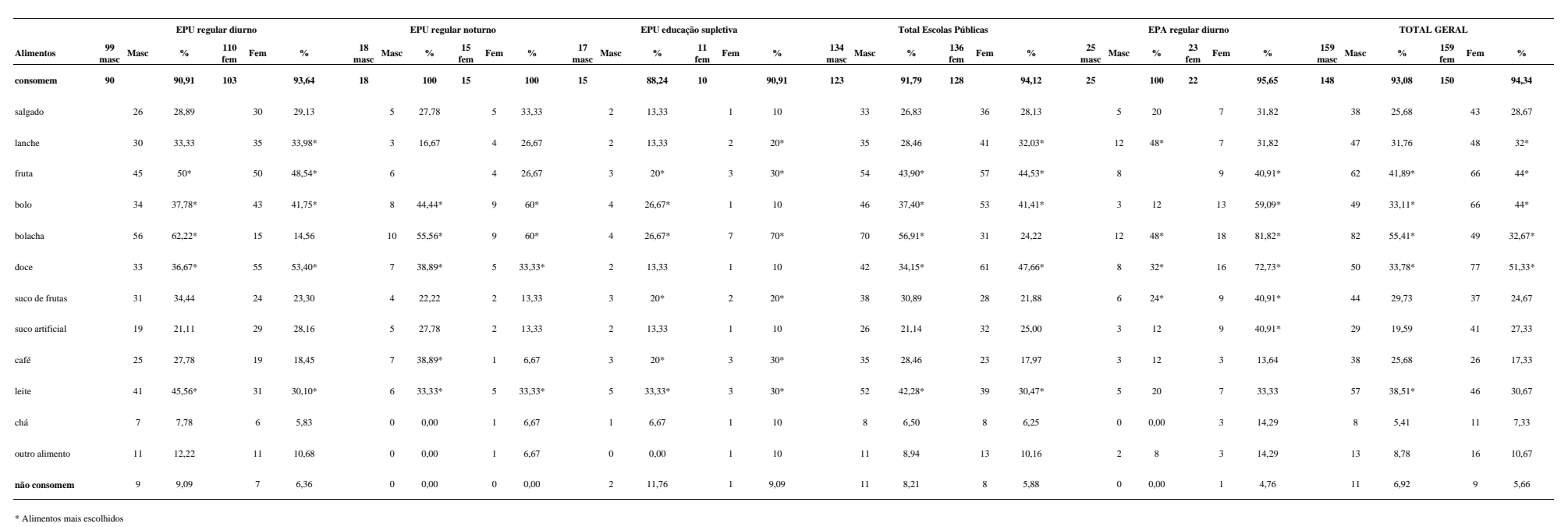




\subsubsection{Quanto ao Jantar}

Os dados quanto à ingestão de alimentos pelos alunos no horário do jantar, foram compilados nas Tabelas 5, 5A, 5B, 5C, nas Figuras 8 e 9 e no Quadro 8.

A maioria dos concluintes do ensino fundamental tem o hábito de jantar regularmente, com destaque para os alunos do sexo masculino (Figura 8).

Não foram expressivos os percentuais dos que deixam de fazer essa refeição:

a) entre alunos do período diurno, não jantam:

Zona Urbana:

EPU - 2,08\% do sexo masculino e 6,89\% do feminino - total 4,59\%

EPA -13,33\% do sexo masculino e 6,52\% do feminino - total 10,38\%

Zona Rural:

EPU - 0\% do sexo masculino e 8,77\% do feminino - total 4,35\%

b) entre alunos do período noturno, não jantam:

EPU regular 9,86\% masculino e 11,11\% feminino - total 10,49\%

EPU de educação supletiva 6,90\% masculino e 13,24\% feminino - total 10,32\%. Pode ser observado que há incidência maior de alunos que não jantam quando o aluno freqüenta aulas no período noturno.

\subsubsection{Comparando-se zona urbana e rural}

Tanto a população masculina quanto a feminina de escolas públicas da rede regular de ensino de zona urbana, aponta os mesmos alimentos como os mais ingeridos no jantar, conforme Tabela 5:

$\begin{array}{llc} & \text { Masculino } & \text { Feminino } \\ 1^{\circ} \text { Arroz } & 95,76 \% & 94,13 \% \\ 2^{\circ} \text { Feijão } & 92,04 \% & 91,07 \% \\ 3^{\circ} \text { Frango } & 63,40 \% & 73,47 \% \\ 4^{\circ} \text { Carne de Vaca } & 60,48 \% & 67,86 \%\end{array}$


$5^{\circ}$ Verduras Cruas $\quad 43,77 \% \quad 61,22 \%$

Observa-se algumas pequenas variações entre alunos da rede regular de ensino noturno, descritas mais adiante.

Na zona rural foram apontados:

Masculino

Feminino

$1^{\circ}$ Arroz e feijão $\quad 100 \%$

$1^{\circ}$ Arroz e feijão $\quad 100 \%$

$2^{\circ}$ Frango $\quad 77,59 \%$

$2^{\circ}$ Frango $\quad 81,13 \%$

$3^{\circ}$ Carne de Vaca $\quad 70,69 \%$

$3^{\circ}$ Verduras cruas $73,58 \%$

$4^{\circ}$ Verduras cruas $\quad 68,97 \%$

$4^{\circ}$ Carne de Vaca $\quad 64,15 \%$

$5^{\circ}$ Macarrão $\quad 34,48 \%$

$5^{\circ}$ Macarrão $\quad 41,51 \%$

A fonte de proteína animal preferida é a carne de frango tanto por estudantes da zona urbana quanto de zona rural, na rede de ensino público no jantar; apenas nas escolas de categoria A é maior o consumo de carne bovina; na rede particular predomina o consumo de carne bovina nas escolas de categoria $\beta \varepsilon \chi$; nas de categoria $\alpha$ consomem mais carne de frango; peixes são os menos consumidos tanto nas escolas públicas quanto nas particulares; nas particulares de categoria $\beta$ o que menos consomem é a carne de porco (Quadro 8).

Quanto ao consumo de lanches, muito provavelmente pelo alto custo, aparece com destaque apenas entre alunos de escolas particulares: 49,55\% do sexo masculino e 40,96\% do feminino (Tabela 5).

Entre os demais, prevalece a ingestão do arroz e feijão, preparação característica do chamado hábito alimentar do brasileiro que, aliás, é muito saudável, pois a lisina de um e a metionina de outro se complementam, podendo estar suprindo as necessidades protéicas do indivíduo. 


\subsubsection{Comparando-se por período de funcionamento das escolas de zona urbana}

Observa-se que apenas entre os alunos do sexo masculino da rede regular de ensino noturno, a maioria engajada no mercado de trabalho, a carne de porco é ingerida com destaque no jantar (50,70) (Tabela 5).

Também entre esses alunos ganha expressão o consumo de macarrão, tanto pelo sexo masculino (50,70\%) quanto pelo feminino (55,38\%), entre os primeiros cinco alimentos apontados como os mais ingeridos (Tabela 5).

Somente para esse mesmo grupo de alunos, tanto do sexo masculino quanto do feminino, não há destaque para o consumo de verduras cruas (Tabela 5).

Pode-se concluir que há um comportamento diferenciado nos alunos do ensino público regular noturno, quanto aos hábitos alimentares. Quanto às opções dos alunos da educação supletiva, também trabalhadores e estudantes do período noturno, se assemelham às dos alunos do diurno (Figura 9).

Vários fatores podem ser objeto de futuros estudos, para se verificar os determinantes desse comportamento.

O peixe não ocupa lugar de destaque entre os cinco primeiros alimentos escolhidos, em nenhum grupo de alunos do diurno ou do noturno, porém é interessante se observar que é mais aceito por alunos da educação supletiva: $24,56 \%$ do sexo masculino e 29,31\% do sexo feminino. Estes alunos são adultos e, muito provavelmente, podem estar cientes do valor nutricional desse alimento.

\subsubsection{Comparando-se por modalidade de curso}

Há uma observação que chama a atenção; os alunos já adultos da educação supletiva, demonstram ter preferências mais semelhantes às dos alunos da rede regular de ensino do período diurno, a maioria adolescentes, que às dos alunos do ensino regular noturno que são mais amadurecidos e, como eles, inseridos no mercado de trabalho (Tabela 5). 
Também pode ser observado nas escolas particulares, que o $2^{\circ}$ alimento mais escolhido pelo sexo feminino é verdura crua e carne de frango, enquanto que para o masculino é carne de vaca.

\subsubsection{Comparando-se por sexo}

Observa-se que os cinco alimentos mais ingeridos durante o jantar, são os mesmos entre alunos de ambos os sexos seja na zona urbana ou rural; há uma inversão na ordem de preferência entre o $3^{\circ}$ e $4^{\circ}$ item apontados na zona rural (carne de vaca e verduras cruas), como já se expôs anteriormente (Tabela 5).

\subsubsection{Comparando-se por categoria de escolas}

Analisando-se o consumo de proteína de origem animal no jantar, observa-se que entre alunos das escolas de categoria A, públicas, há maior ingestão de carne bovina, enquanto nas de categoria $\alpha$, particulares, a preferência é por frango (Quadro 8).

Nas escolas públicas urbanas de categoria B e C, assim como nas de zona rural, os alunos informam consumir prioritariamente a carne de frango; nas escolas particulares de categoria $\beta \varepsilon \chi$, é maior o consumo de carne bovina (Quadro 8).

É curioso se observar que há uma inversão entre as preferências no consumo de proteína animal entre alunos de escolas públicas e particulares, nas diferentes categorias (Quadro 8).

Os peixes são a fonte de proteínas com menor percentual de consumo tanto em escolas públicas quanto nas particulares, de zona urbana e rural; há uma exceção em escolas particulares de categoria $\beta$, onde a carne de porco é a fonte com menor percentual de consumo (Quadro 8).

Os lanches, como já mencionado, só aparece entre os cinco primeiros itens de consumo no jantar, entre alunos de escolas particulares; e, curiosamente, aparece com 
maior percentual entre alunos das escolas de categoria $\chi$ e menor nas de categoria $\beta$

(Tabela 5B e 5C). Entre alunos das escolas públicas, os que menos consomem o referido item são os alunos da rede regular de ensino de zona rural, possivelmente por não terem fácil acesso aos fast-foods, que vêm influenciando os hábitos alimentares da população de zona urbana (Tabela 5 e Figura 9).

Verduras cruas também são bastante consumidas. Observando-se o total geral das categorias de escolas nas Tabelas 5A, 5B e 5C, vê-se os percentuais de alunos do sexo masculino e feminino que as consomem:

$\begin{array}{lcc} & \text { Masculino } & \text { Feminino } \\ \text { Categorias A e } \alpha & 31,06 \% & 42,97 \% \\ \text { Categorias B e } \beta & 37,16 \% & 49,21 \% \\ \text { Categorias C e } \chi & 52,83 \% & 62,26 \%\end{array}$

Percebe-se claramente:

- que os alunos de escolas estaduais centrais e das particulares mais dispendiosas, são os que menos têm o hábito de incluir verduras cruas no jantar;

- que esses percentuais se elevam entre os alunos, em proporção direta em direção à periferia da cidade e barateamento nos preços das mensalidades das escolas particulares.

Observa-se também que os alunos de escolas particulares são os que menos incluem verduras cruas no jantar e que os alunos da educação supletiva, adultos, são os que mais o fazem (Figura 9). Parece possível inferir que os alunos das escolas particulares estejam aderindo aos lanches e fast-food, no jantar, o que os afasta do consumo das verduras cruas.

Os fatores determinantes desses comportamentos podem ser objeto de futuros estudos. 


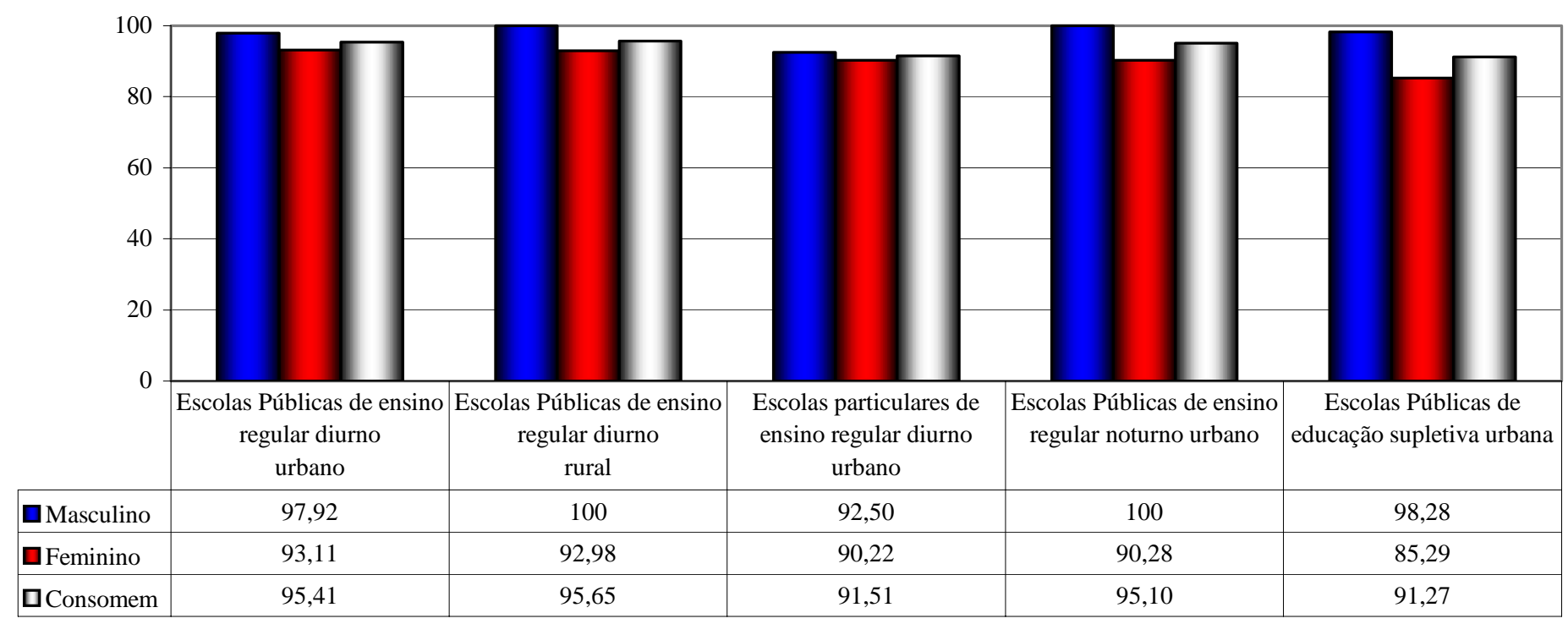

Figura 8 Percentuais de alunos que ingerem alimentos no horário do jantar, nas escolas públicas e particulares de diferentes categorias - Piracicaba (SP), 2004 


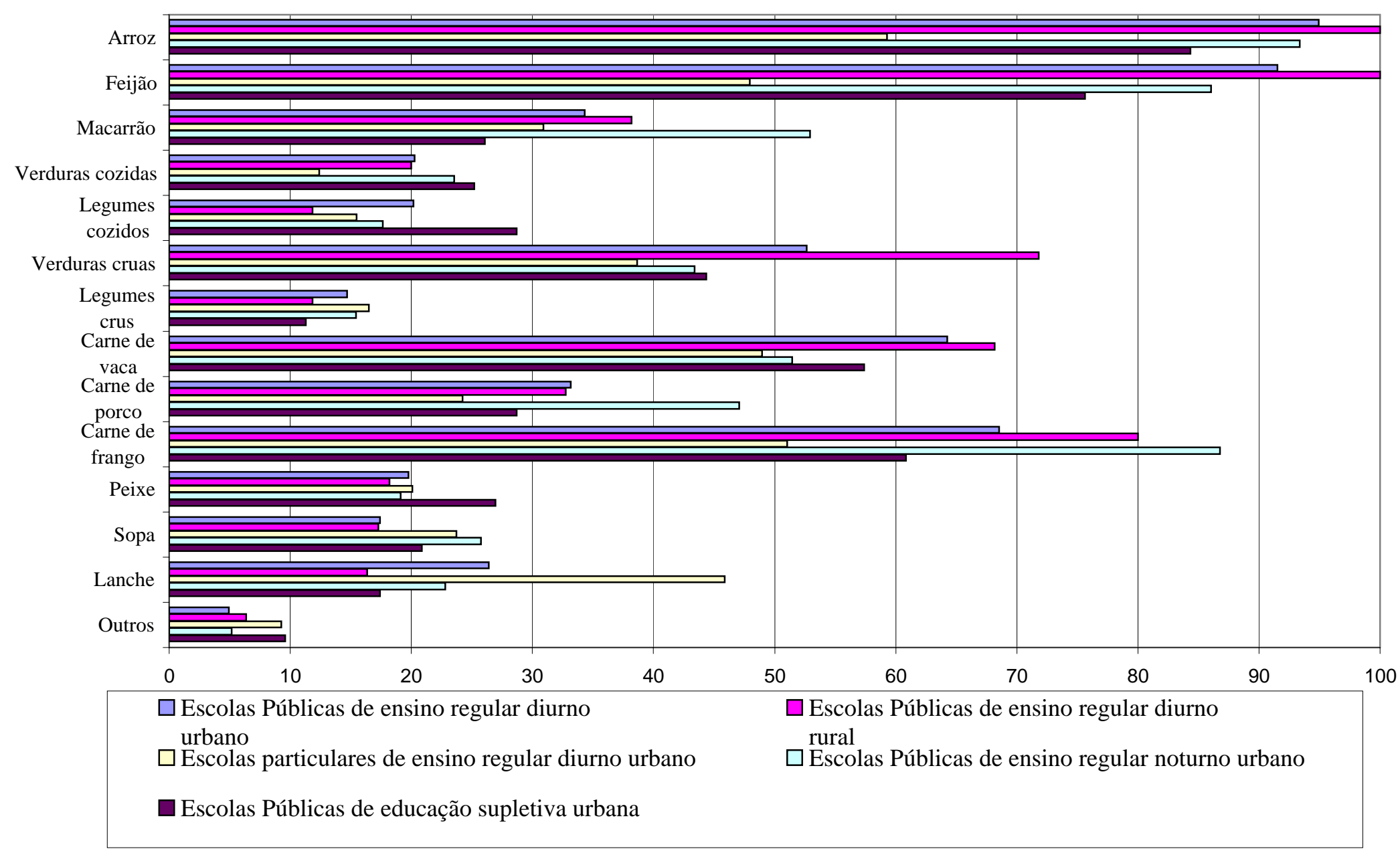

Figura 9 Alimentos ingeridos no jantar- Piracicaba (SP), 2004 


\begin{tabular}{|c|c|c|c|c|c|c|c|c|c|c|c|c|}
\hline Escolas Públicas & $\begin{array}{c}\mathrm{A} \\
\mathrm{masc}\end{array}$ & $\begin{array}{c}A \\
\text { fem }\end{array}$ & $\begin{array}{c}A \\
\text { total }\end{array}$ & $\begin{array}{c}\mathrm{B} \\
\text { masc }\end{array}$ & $\begin{array}{c}B \\
\text { fem }\end{array}$ & $\begin{array}{c}\mathrm{B} \\
\text { total }\end{array}$ & $\begin{array}{c}\mathrm{C} \\
\operatorname{masc}\end{array}$ & $\begin{array}{c}C \\
\text { fem }\end{array}$ & $\begin{array}{c}\mathrm{C} \\
\text { total }\end{array}$ & $\begin{array}{l}\text { Rural } \\
\text { masc }\end{array}$ & $\begin{array}{c}\text { Rural } \\
\text { fem }\end{array}$ & $\begin{array}{c}\text { Rural } \\
\text { total }\end{array}$ \\
\hline came bovina & $55,64 \%$ & $52,12 \%$ & $56,37 \%$ & $56,21 \%$ & $71,92 \%$ & $63,87 \%$ & $68,69 \%$ & $69,18 \%$ & $68,42 \%$ & $70,69 \%$ & $59,65 \%$ & $65,22 \%$ \\
\hline carne de frango & $54,89 \%$ & $55,76 \%$ & $55,36 \%$ & $63,40 \%$ & $78,08 \%$ & $70,56 \%$ & $69,70 \%$ & $74,55 \%$ & $72,24 \%$ & $77,59 \%$ & $75,44 \%$ & $76,52 \%$ \\
\hline carne de porco & $36,84 \%$ & $21,21 \%$ & $28,18 \%$ & $36,60 \%$ & $38,36 \%$ & $37,45 \%$ & $33,33 \%$ & $23,64 \%$ & $28,22 \%$ & $32,76 \%$ & $29,82 \%$ & $31,30 \%$ \\
\hline peixes & $11,28 \%$ & $9,09 \%$ & $10,06 \%$ & $26,80 \%$ & $18,49 \%$ & $22,74 \%$ & $29,29 \%$ & $22,73 \%$ & $25,83 \%$ & $22,41 \%$ & $12,28 \%$ & $17,39 \%$ \\
\hline Escolas Particulares & $\alpha$ & $\alpha$ & $\alpha$ & $\beta$ & $\beta$ & $\beta$ & $x$ & $x$ & $x$ & & & \\
\hline carne bovina & $55,00 \%$ & $14,89 \%$ & $37,38 \%$ & $26,87 \%$ & $14,89 \%$ & $21,49 \%$ & $72,00 \%$ & $60,87 \%$ & $66,66 \%$ & & & \\
\hline carne de frango & $63,33 \%$ & $25,63 \%$ & $46,72 \%$ & $21,67 \%$ & $19,15 \%$ & $20,56 \%$ & $44,00 \%$ & $68,57 \%$ & $56,25 \%$ & & & \\
\hline carne de porco & $30,00 \%$ & $8,51 \%$ & $20,56 \%$ & $6,67 \%$ & $4,26 \%$ & $5,60 \%$ & $44,00 \%$ & $34,78 \%$ & $35,41 \%$ & & & \\
\hline peixes & $21,67 \%$ & $23,40 \%$ & $19,62 \%$ & $8,33 \%$ & $10,54 \%$ & $9,34 \%$ & $28,00 \%$ & $13,04 \%$ & $20,83 \%$ & & & \\
\hline & \multirow{2}{*}{\multicolumn{12}{|c|}{ fonte mais consumida }} \\
\hline & & & & & & & & & & & & \\
\hline
\end{tabular}

Quadro 8 Percentuais de ingestão de principais fontes proteicas de origem animal entre alunos do período diurno, no jantar Piracicaba (SP), 2004 


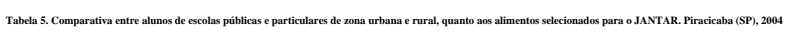

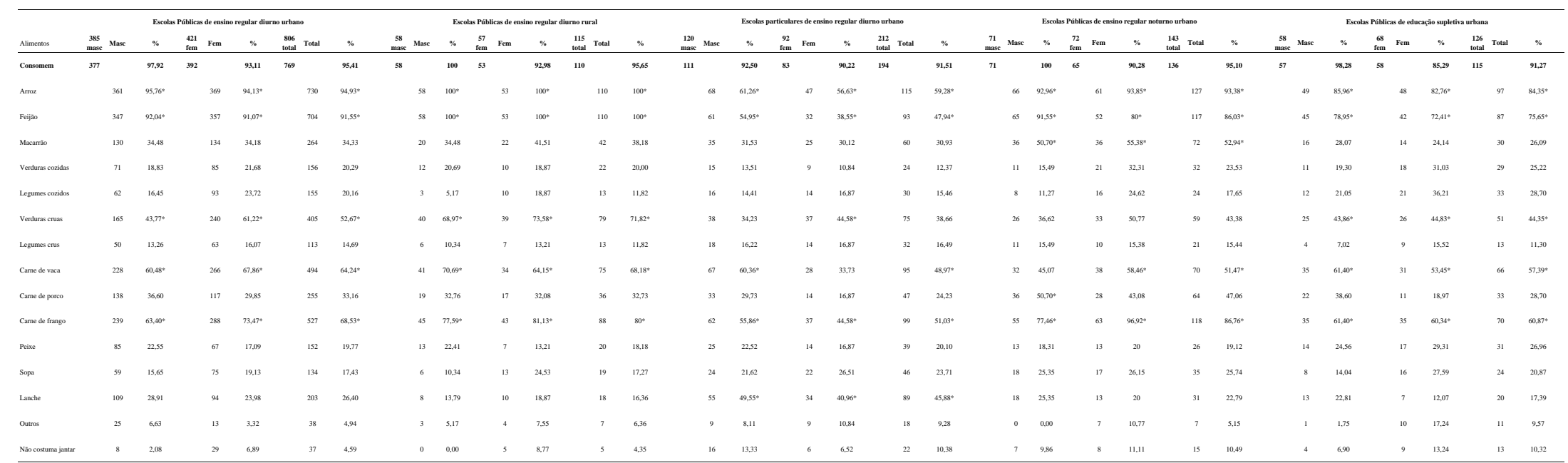


Tabela 5A. Alimentos selecionados para o JANTAR por 100\% dos sujeitios de pesquisa que frequentam escolas publicas de categoria A e particulares $\alpha$ Zona Urbana. Piracicaba (SP), 2004

\begin{tabular}{|c|c|c|c|c|c|c|c|c|c|c|c|c|c|c|c|c|c|c|c|c|c|c|c|c|}
\hline \multirow[b]{2}{*}{ Alimentos } & \multicolumn{4}{|c|}{ EPU regular diurno } & \multicolumn{4}{|c|}{ EPU regular noturno } & \multicolumn{4}{|c|}{ EPU educaăăo supletiva } & \multicolumn{4}{|c|}{ Total Escolas Públicas } & \multicolumn{4}{|c|}{ EPA regular diurno } & \multicolumn{4}{|c|}{ TOTAL GERAL CATEGORIAS } \\
\hline & $\begin{array}{l}{ }_{\text {masc }}^{133} \text { Masc } \\
\text { masc }\end{array}$ & $\%$ & $\begin{array}{l}\text { fem } \\
\text { fem }\end{array}$ & $\%$ & $\begin{array}{l}\text { masc Masc } \\
\text { masc }\end{array}$ & $\%$ & $\begin{array}{l}17 \\
\text { fem }\end{array}$ & $\%$ & $\begin{array}{l}\text { 196 Masc } \\
\text { masc }\end{array}$ & $\%$ & $\begin{array}{l}\text { 热m } \\
\text { fem }\end{array}$ & $\%$ & $\begin{array}{l}175 \\
\text { masc Masc }\end{array}$ & $\%$ & $\begin{array}{l}\text { fem } \\
\text { fem }\end{array}$ & $\%$ & $\begin{array}{l}{ }_{\text {masc }}^{60} \text { Masc } \\
\text { masc }\end{array}$ & $\%$ & $\begin{array}{l}47 \mathrm{Fem} \\
\text { fem }\end{array}$ & $\%$ & 每35s Masc & $\%$ & $\begin{array}{l}\text { fem } \\
\text { fem }\end{array}$ & $\%$ \\
\hline Arroz & 115 & $86,47^{*}$ & 113 & $68,48^{*}$ & 23 & $100^{+*}$ & 16 & $94,12^{*}$ & 16 & $84,21^{*}$ & 23 & $67,65^{\circ}$ & 154 & $88^{*}$ & 152 & $70,37^{*}$ & 36 & ${ }^{60^{*}}$ & 18 & $38,30^{*}$ & 190 & $80,55^{*}$ & 170 & $64,64^{*}$ \\
\hline Fejijāo & 109 & $81,5^{*}$ & 123 & $74,55^{*}$ & 23 & $100^{*}$ & 14 & $82,35^{*}$ & 16 & $84,21^{*}$ & 21 & $61,76^{*}$ & 148 & $84,57 *$ & 158 & $73,15^{*}$ & 33 & $55^{*}$ & 13 & $27,66^{*}$ & 181 & $7,02^{*}$ & 171 & $65,0^{2 *}$ \\
\hline Macarã̃a & 42 & 31,58 & 40 & 24,24 & 10 & $43,48^{*}$ & 9 & $52,94^{*}$ & 5 & 26,32 & 4 & 11,76 & 57 & 32,57 & 53 & 24,54 & 21 & 35 & 11 & 23,40 & 78 & 33,19 & 64 & 24,33 \\
\hline Verduras cozidas & 20 & 15,04 & 23 & 13,94 & 4 & 17,39 & 8 & $47,06^{*}$ & 4 & 21,05 & 9 & 26,47 & 28 & 16 & 40 & 18,52 & 10 & 16,67 & 5 & 10,64 & 38 & 16,17 & 45 & 17,11 \\
\hline Legumes cozidos & 14 & ${ }_{10,53}$ & 27 & 16,36 & 1 & 4,35 & 5 & 29,41 & 3 & 15,79 & 12 & $35,29^{*}$ & 18 & 10,29 & 44 & 20,37 & 7 & 11,67 & 6 & 12,77 & 25 & 10,64 & 50 & 19,01 \\
\hline Verduras cruas & 40 & 30,08 & 75 & $45,45^{*}$ & 7 & 30,43 & 8 & $47,06^{*}$ & 9 & $4,377^{*}$ & 11 & $32,35^{*}$ & 56 & 32 & 94 & $43,2^{*}$ & 17 & 28,33 & 19 & $40,43^{*}$ & 73 & 31,06 & 113 & $42,97 *$ \\
\hline Legumes cus & 12 & 9,02 & 24 & 14,55 & 3 & 13,04 & 1 & 5,88 & 3 & 15,79 & 5 & ${ }^{14,71}$ & 18 & 10,29 & 30 & 13,89 & 10 & 16,67 & 6 & 12,77 & 28 & 11,91 & 36 & ${ }^{13,69}$ \\
\hline Cane de vaca & 74 & $55,6^{*}$ & 86 & $52,12^{*}$ & 5 & 21,74 & 8 & $47,06^{*}$ & 13 & $68,42^{*}$ & 15 & $44,12^{*}$ & 92 & $52,57^{*}$ & 109 & $50,46^{*}$ & 33 & $55^{*}$ & 7 & 14,89 & 125 & $53,19^{*}$ & 116 & $44,11^{*}$ \\
\hline Came de porco & 49 & $36,84^{*}$ & 35 & 21,21 & 11 & $47,83^{*}$ & 7 & 41,18 & 8 & 42,11 & 5 & 14,71 & 68 & $38,86^{*}$ & 47 & 21,76 & 18 & 30 & 4 & 8,51 & 86 & $36,60^{*}$ & 51 & 19,39 \\
\hline Came de frango & 73 & $54,899^{*}$ & 92 & $55,76^{*}$ & 20 & $86,96^{*}$ & 11 & $64,71^{*}$ & 13 & $68,42^{*}$ & 14 & $41,18^{*}$ & 106 & $60,57^{*}$ & 117 & $54,17^{*}$ & 38 & $63,33^{*}$ & 12 & $25,53^{*}$ & 144 & $61,28^{*}$ & 129 & $49,05^{*}$ \\
\hline Peixe & 15 & 11,28 & 15 & 9,09 & 3 & 13,04 & 4 & 23,53 & 7 & 36,84 & 12 & $35,29^{\circ}$ & 25 & 14,29 & 31 & 14,35 & 13 & ${ }^{21,67}$ & 6 & 12,77 & 38 & 16,17 & 37 & 14,07 \\
\hline Sopa & 20 & 15,04 & 21 & 12,73 & 5 & 21,74 & 7 & 41,18 & 3 & 15,79 & 4 & 11,76 & 28 & 16 & 32 & 14,81 & 13 & ${ }^{21,67}$ & 11 & 23,40 & 41 & 17,45 & 43 & 16,35 \\
\hline Lanche & 41 & 30,83 & 28 & 16,97 & 5 & 21,74 & 1 & 5,88 & 9 & 47,37 & 3 & 8,82 & 55 & 31,43 & 32 & 14,81 & 27 & $45^{*}$ & 16 & $34,044^{*}$ & 82 & 34,89 & 48 & ${ }^{18,25}$ \\
\hline Nä̀ costuma jantar & 1 & 0,75 & 8 & 4,85 & 0 & 0,00 & 0 & 0 & 1 & 5,26 & 5 & 14,71 & 2 & 1,14 & 13 & 6,02 & 3 & 5 & 3 & 13,64 & 5 & 2,13 & 16 & 6,08 \\
\hline Ourros & 6 & 4,51 & 4 & 2,42 & 2 & 6,67 & ${ }^{4}$ & 10 & 3 & 15,79 & 7 & 20,59 & 11 & 6,29 & 15 & 6,94 & 8 & 13,33 & 1 & 4,55 & 19 & 8,09 & 16 & 6,08 \\
\hline
\end{tabular}


Tabela 5B. Alimentos selecionados para o JANTAR por 100\% dos sujeitos de pesquisa que frequentam escolas pubblicas de categoria B e particulares $\beta$ (Zona Urbana). Piracicaba (SP), 2004

\begin{tabular}{|c|c|c|c|c|c|c|c|c|c|c|c|c|c|c|c|c|c|c|c|c|c|c|c|c|}
\hline \multirow[b]{2}{*}{ Alimentos } & \multicolumn{4}{|c|}{ EPU regular diurno } & \multicolumn{4}{|c|}{ EPU regular noturno } & \multicolumn{4}{|c|}{ EPU educasẵo supleteiva } & \multicolumn{4}{|c|}{ Total Escolas Públicas } & \multicolumn{4}{|c|}{ EPA regular diurno } & \multicolumn{4}{|c|}{ TOTAL GERAL CATEGORIAS } \\
\hline & 1534 Masc & $\%$ & & $\%$ & $\begin{array}{l}30 \\
\text { masc Masc } \\
\text { masc }\end{array}$ & $\%$ & $\begin{array}{l}\text { tem } \\
\text { fem }\end{array}$ & $\%$ & $\begin{array}{l}\frac{18}{18} \text { Masc } \\
\text { Masc } \\
\text { mats }\end{array}$ & $\%$ & $\begin{array}{l}\text { fem } \\
\text { fem }\end{array}$ & $\%$ & 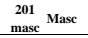 & $\%$ & $\begin{array}{l}\text { 200 } \\
\text { femm }\end{array}$ & $\%$ & $\begin{array}{l}{ }_{\text {masc }}^{60} \text { Masc } \\
\text { mas }\end{array}$ & $\%$ & $\begin{array}{l}47 \text { Fem } \\
\text { fem }\end{array}$ & $\%$ & 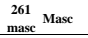 & $\%$ & $\begin{array}{l}\text { tem } \\
\text { fem }\end{array}$ & $\%$ \\
\hline Arroz & 147 & $96,08^{*}$ & 14 & $100^{*}$ & 26 & $86,64^{*}$ & 31 & $77,50^{*}$ & 16 & $88,89^{*}$ & 19 & $90,4^{*}$ & 189 & $94,0^{*}$ & 196 & $94,69^{*}$ & 16 & $26,67^{*}$ & 13 & $27,66^{*}$ & 205 & $78,54^{*}$ & 209 & $82,28^{*}$ \\
\hline Feijâa & 139 & 90,85* & $13 \mathrm{C}$ & $89,04-$ & 25 & $83,33^{*}$ & 25 & $62,50^{*}$ & 13 & $72,22^{*}$ & 16 & $76,19^{*}$ & 177 & $88,06^{*}$ & 171 & $82,61^{*}$ & 13 & $21,67^{*}$ & 9 & $19,15^{*}$ & 190 & $72,80^{*}$ & 180 & $70,87^{*}$ \\
\hline Macarãăo & 47 & 30,72 & 56 & 38,36 & 20 & $66,67^{*}$ & 22 & $55^{*}$ & 8 & $44,44^{*}$ & 6 & 28,57 & 75 & 37,31 & 84 & ${ }_{40,58}$ & 6 & 10 & 4 & 8,51 & 81 & 31,03 & 88 & 34,65 \\
\hline Verdura cozida & 26 & 16,99 & 31 & 21,23 & 5 & 16,67 & 12 & 30 & 6 & 33,33 & 7 & 33,33 & 37 & 18,41 & 50 & 24,15 & 3 & 5 & 2 & 4,26 & 40 & 15,33 & 52 & 20,47 \\
\hline Legumes cozidos & 27 & 17,65 & 27 & 18,49 & 5 & 16,67 & 10 & 25,00 & 6 & 33,33 & 8 & 38,10 & 38 & 18,91 & 45 & 21,74 & 7 & 11,67 & 2 & 4,26 & 45 & 1,24 & 47 & 18,50 \\
\hline verdura cuna & 66 & $43,14^{*}$ & 89 & $60,96-$ & ${ }_{11}$ & 36,67 & 16 & 40 & 8 & $44,44^{*}$ & ${ }_{11}$ & $52,38^{*}$ & 85 & $42,2^{*}$ & 116 & $56,04 *$ & 12 & 20 & 9 & $19,15^{*}$ & 97 & $37,16^{*}$ & 125 & $49,21^{*}$ \\
\hline Legume cru & 19 & 12,42 & 15 & 10,27 & 5 & 16,67 & 6 & 15,00 & 1 & 5,56 & 3 & 14,29 & 25 & 12,44 & 24 & 11,59 & 3 & 5 & 4 & 8,51 & 28 & 10,73 & 28 & 11,02 \\
\hline Carne de vaca & 86 & $56,21^{*}$ & 10 & $7,1,22$ & 17 & $56,67^{*}$ & 25 & $62,50^{*}$ & 13 & $72,22^{*}$ & 11 & $52,3 \mathrm{~B}^{*}$ & 116 & $57,1^{*}$ & 141 & $68,12^{*}$ & 16 & $26,67^{*}$ & 7 & 14,89 & 132 & $50,57^{*}$ & 148 & $58,27^{*}$ \\
\hline Came de porco & 56 & 36,60 & 56 & 38,36 & 14 & 46,67 & 15 & 37,50 & 7 & 38,89 & 4 & 19,05 & 77 & 38,31 & 75 & 36,23 & 4 & 6,67 & 2 & 4,26 & 81 & 31,03 & 77 & 30,31 \\
\hline Came de frango & 97 & $63,40^{*}$ & 114 & $\begin{array}{ll}78,08 \\
\end{array}$ & 19 & $63,33^{*}$ & 27 & $67,50^{*}$ & 12 & $66,67^{*}$ & 14 & $66,67^{\circ}$ & 128 & $63,68^{*}$ & 155 & $74,88^{*}$ & 13 & $21,67^{*}$ & 9 & $19,15^{*}$ & 141 & $54,02^{*}$ & 164 & $64,57^{*}$ \\
\hline Peixe & 41 & 26,80 & 27 & 18,49 & 6 & 20 & 8 & 20 & 3 & 16,67 & 3 & 14,29 & 50 & 24,88 & 38 & 18,36 & 5 & 8,33 & 5 & 10,64 & 55 & 21,07 & 43 & 16,93 \\
\hline Sopa & 23 & 15,03 & 32 & 21,92 & 9 & 30 & 9 & 22,50 & 4 & 22,22 & 9 & 42,86 & 36 & 17,91 & 50 & 24,15 & 4 & 6,67 & 3 & 6,38 & 40 & 15,33 & 53 & 20,87 \\
\hline Lanche & 48 & 31,37 & 49 & 33,56 & 9 & 30 & 11 & 27,50 & 3 & 16,67 & 4 & 19,05 & 60 & 29,85 & 64 & 30,92 & 16 & $26,67^{*}$ & 4 & 8,51 & 76 & 29,12 & 68 & 26,77 \\
\hline Não janta & 2 & 1,31 & 12 & 8,22 & 0 & 0,00 & 6 & 15 & 0 & 0,00 & 1 & 4,76 & 2 & 1 & 19 & 9,18 & 4 & 6,67 & 4 & $18,18^{*}$ & 6 & 2,30 & 23 & 9,06 \\
\hline Outros & 11 & 7,19 & 6 & 4,11 & 4 & ${ }_{13,33}$ & ${ }_{4}$ & 10 & 0 & 0,00 & 2 & 9,52 & 15 & ${ }_{7,46}$ & 12 & 5,80 & 5 & 8,33 & 2 & 9,09 & 20 & 7,66 & 14 & 5,51 \\
\hline
\end{tabular}


Tabela 5C. Alimentos selecionados para o JANTAR por 100\% dos sujeitos de pesquisa que frequentam escolas püblicas de categoria C e particulares c (Zona Urbana). Piracicaba (SP), 2004

\begin{tabular}{|c|c|c|c|c|c|c|c|c|c|c|c|c|c|c|c|c|c|c|c|c|c|c|c|c|c|c|}
\hline \multirow[b]{2}{*}{ Alimentos } & \multicolumn{4}{|c|}{ EPU regular diurno } & \multicolumn{5}{|c|}{ EPU regular noturno } & \multicolumn{4}{|c|}{ EPU educasăo supletiva } & \multicolumn{5}{|c|}{ Total Escolas Prublicas } & \multicolumn{4}{|c|}{ EPA regular diurno } & \multicolumn{4}{|c|}{ TOTAL GERAL CATEGORIAS } \\
\hline & $\begin{array}{cc}99 & \text { Masc } \\
\text { masc } & \text { Casc }\end{array}$ & $\begin{array}{cc}110 \\
\text { fem }\end{array}$ & $\begin{array}{ll}0 \\
n\end{array}$ & $\%$ & $\underset{\text { masc }}{18}$ Masc & $\%$ & $\begin{array}{r}15 \quad F \\
\text { fem }\end{array}$ & Fem & $\%$ & $\begin{array}{c}17 \\
\text { masc }\end{array}$ Masc & $\%$ & $\begin{array}{l}11 \\
\text { fem }\end{array}$ & $\%$ & $\begin{array}{l}134 \\
\text { masc }\end{array}$ & $\%$ & $\begin{array}{l}{ }_{\text {fem }}^{136} \quad F \\
\text { fer }\end{array}$ & Fem & $\%$ & $\begin{array}{l}25 \\
\text { masc }\end{array}$ Masc & $\begin{array}{ll}23 \\
\% \\
\mathrm{fen}\end{array}$ & $\begin{array}{ll}23 & \text { Fem }\end{array}$ & $\%$ & $\begin{array}{l}159 \text { Masc } \\
\text { masc }\end{array}$ & $\%$ & $\begin{array}{l}159 \\
\text { fem }\end{array}$ & n $\%$ \\
\hline Arroz & 99 & $100^{*}$ & 110 & $100^{*}$ & 17 & $94,44^{*}$ & & 1493 & $93,33^{*}$ & 17 & $100^{*}$ & 8 & $72,73^{*}$ & 133 & $99,2^{*}$ & & $132 \quad 97$ & $97,06^{*}$ & 16 & $64^{*}$ & 16 & $69,5 \%$ & 149 & $93,7^{*}$ & 148 & 393,08 \\
\hline Feijàa & 99 & $100^{*}$ & 104 & $94,55^{*}$ & 17 & $94,44^{*}$ & & $\begin{array}{ll}13 & 32\end{array}$ & $32,50^{*}$ & 16 & $94,12^{*}$ & 5 & $45,45^{*}$ & 132 & $98,51^{*}$ & & 122 & $89,7^{*}$ & 15 & $60^{*}$ & 12 & $52,17^{*}$ & 147 & $92,45^{*}$ & 134 & 84,28 \\
\hline Macarăa & 41 & 41,41 & 38 & 34,55 & 6 & 33,33 & & 6 & $15^{*}$ & 3 & 17,65 & 2 & 18,18 & 50 & 37,31 & & 46 & 33,82 & 8 & 32 & 10 & 43,48 & 58 & 36,48 & 56 & 35,22 \\
\hline Verdura cozida & 25 & 25,25 & 31 & 28,18 & 2 & 11,11 & & 1 & 2,50 & 1 & 5,88 & 2 & 18,18 & 28 & 20,90 & & 34 & 25 & 2 & 8 & 2 & 8,70 & 30 & 18,87 & 36 & 22,64 \\
\hline Legumes coxidos & 21 & 21,21 & 39 & 35,45 & 2 & 11,11 & & 1 & 2,50 & 3 & 17,65 & 1 & 9,09 & 26 & 19,40 & & 41 & 30,15 & 2 & 8 & 4 & 17,39 & 28 & 17,61 & 45 & 28,30 \\
\hline Verdura crua & 59 & $59,60^{*}$ & 76 & $69,99 *$ & 8 & $44,44^{*}$ & & 9 & $22,50^{*}$ & 8 & $47,06^{*}$ & 4 & $36,36^{*}$ & 75 & $55,97^{*}$ & & 89 & 65,44* & 9 & 36 & 10 & 43,48 & 84 & $52,83^{*}$ & 99 & 62,26 \\
\hline Legume cru & 19 & 19,19 & 24 & 21,82 & 3 & 16,67 & & 3 & 7,50 & 0 & 0,00 & 1 & 9,09 & 22 & 16,42 & & 28 & 20,59 & 5 & 20 & 4 & 17,39 & 27 & 16,98 & 32 & 20,13 \\
\hline Came de vaca & 68 & $68,69 *$ & 75 & $68,18^{*}$ & 10 & $55,6^{*}$ & & $\begin{array}{ll}5 & 12\end{array}$ & 12,50* & 9 & $52,94^{*}$ & 5 & $45,45^{*}$ & 87 & $64,93^{*}$ & & $\begin{array}{ll}85 & 62\end{array}$ & $62,50^{*}$ & 18 & $72^{*}$ & 14 & $60,87^{*}$ & 105 & $66,04^{*}$ & 99 & 62,26 \\
\hline Came de porco & 33 & 33,33 & 26 & 23,64 & ${ }_{11}$ & 61,11 & & 6 & $15^{*}$ & 7 & 41,18 & 2 & 18,18 & 51 & 38,06 & & 34 & 25 & 11 & $44^{*}$ & 8 & 34,78 & 62 & 38,99 & 42 & 26,42 \\
\hline Carne de frango & 69 & $69,70^{*}$ & 82 & $74,55^{*}$ & 16 & $88,89^{*}$ & & $10 \quad 2$ & $25^{*}$ & 10 & $58,82^{*}$ & 7 & $63,64^{*}$ & 95 & $70,90^{*}$ & & 99 & $72,79^{*}$ & 11 & $44^{*}$ & 16 & $69,57^{*}$ & 106 & $66,67^{*}$ & 115 & $5 \quad 72,33$ \\
\hline Peixe & 29 & 29,29 & 25 & 22,73 & 4 & 22,22 & & 1 & 2,50 & 4 & 23,53 & 2 & 18,18 & 37 & 27,61 & & 28 & 20,59 & 7 & 28 & 3 & 13,04 & 44 & 27,67 & 31 & 19,50 \\
\hline Sopa & 16 & 16,16 & 22 & 20 & 4 & 22,22 & & 12 & 2,50 & 1 & 5,88 & 3 & 27,27 & 21 & 15,67 & & 26 & 19,12 & 7 & 28 & 6 & 26,09 & 28 & 17,61 & 32 & 20,13 \\
\hline Lanche & 20 & 20,20 & 17 & 15,45 & 4 & 22,22 & & 1 & 2,50 & 1 & 5,88 & 0 & 0,00 & 25 & 18,66 & & 18 & 13,24 & 12 & $48^{*}$ & 14 & $60,87^{*}$ & 37 & 23,27 & 32 & 20,13 \\
\hline Nắc costuma jantar & 5 & 5,05 & 9 & 8,18 & 0 & 0,00 & & 1 & 2,50 & 0 & 0,00 & 4 & 36,36 & 5 & 3,73 & & 14 & 10,29 & 2 & 8 & 2 & 8,70 & 7 & 4,40 & 16 & 10,06 \\
\hline Ouros & 8 & 8,08 & 3 & 2,73 & 1 & 3,33 & & 0 & 0 & 1 & 5,88 & 0 & 0,00 & 10 & 7,46 & & 3 & 2,21 & 3 & 12 & 3 & 13,04 & 13 & 8,18 & 6 & 3,77 \\
\hline
\end{tabular}




\subsection{Análise da Seleção de Bebidas}

O percentual de concluintes da rede regular de ensino fundamental que afirma não ingerir líquidos nas refeições, é mínimo: 1,61\% no horário de almoço e 1,01\% em horário de jantar, apesar de não ser aconselhada a ingestão, pelos profissionais da saúde ( Tabelas 6 e 7).

Deixam de tomar líquidos nas refeições, conforme as Tabelas 6 e 7:

a) estudantes do período diurno:

- em escolas particulares: 4,72\% no almoço e 8,96\% no jantar

- em escolas públicas:

na zona urbana $1,61 \%$ no almoço e $8,31 \%$ no jantar

na zona rural ninguém se abstém de bebidas no almoço e 3,48\% no jantar.

b) estudantes do período noturno:

- em escolas da rede regular de ensino 6,99\% no almoço e 4,20\% no jantar

- em escolas de educação supletiva 5,56\% no almoço e 17,46\% no jantar.

\subsubsection{Em horário de almoço}

\subsubsection{Comparando-se zona urbana e rural}

Incluindo as categorias A, B e C, 98,96\% dos alunos do sexo masculino e 97,86\% das alunas de escolas públicas da rede regular de ensino diurno, em zona urbana, ingerem bebidas durante o almoço; nas particulares os percentuais são 97,50\% para o sexo masculino e 91,30\% para o feminino, incluindo-se escolas de categorias $\alpha, \beta$ e $\chi$ (Tabela 6).

Na zona rural com $100 \%$ dos alunos do sexo masculino e $100 \%$ das alunas, ocorre o mesmo.

Em todos os grupos de estudo, os percentuais dos que ingerem bebidas no almoço é elevado; nas escolas públicas o que mais bebem é o refrigerante e nas particulares, o suco de frutas; apenas as alunas da educação supletiva afirmam preferir água (Tabela 6). 


\subsubsection{Comparando-se por período de funcionamento das escolas de zona urbana}

A ingestão de água durante o almoço tem percentuais em destaque entre os alunos do período noturno e mais na rede de educação supletiva que na rede regular de ensino; em ambas as redes é maior o percentual da população feminina adepta do hábito (Tabela 6 e Figura 10).

O refrigerante é bastante ingerido por alunos de ambos os períodos; os alunos que menos o consomem são os da educação supletiva (noturno) e das escolas particulares (diurno) (Tabela 6 e Figura 10).

O suco natural de frutas e também o artificial são mais ingeridos por alunos do período diurno, e mais o artificial que o natural em escolas públicas; nas escolas particulares há maior consumo de suco natural (Tabela 6 e Figura 10).

O consumo de leite e café no almoço é pouco expressivo e maior entre os alunos do período noturno (Tabela 6 e Figura 10).

\subsubsection{Comparando-se por modalidade de curso}

A água é mais consumida no almoço, entre alunas da educação supletiva (52,46\%) e da rede regular de ensino noturno (52,31\%) (Tabela 6).

O refrigerante tem maior expressão entre os alunos da rede regular de ensino diurno e noturno, ocorrendo o mesmo com o suco natural e artificial (Figura 10).

O leite e café são mais consumidos pelos alunos da rede regular que da educação supletiva (Figura 10).

\subsubsection{Comparando-se por sexo}

São menores os percentuais dos alunos do sexo masculino que demonstram ingerir água durante o almoço (Tabela 6).

Os percentuais referentes a refrigerantes são maiores para o sexo masculino, com exceção das alunas da rede regular de ensino noturno (Tabela 6). 
O suco natural de frutas é mais ingerido entre a população feminina, com exceção dos alunos da educação supletiva (Tabela 6).

O suco artificial é mais ingerido pela população masculina, com exceção das escolas particulares, onde há mais elementos do sexo feminino que o ingerem.

A ingestão de leite, apesar de mínima, é maior entre os alunos do sexo masculino; o café também, com exceção da zona rural, onde foi maior o percentual de alunas que afirmam tomá-lo em horário de almoço.

\subsubsection{Comparando-se por categoria de escolas}

\begin{tabular}{|c|c|c|c|c|c|c|c|c|}
\cline { 2 - 9 } \multicolumn{1}{c|}{} & \multicolumn{2}{c|}{ Água } & \multicolumn{2}{c|}{ Refrigerante } & \multicolumn{2}{c|}{ Suco de Frutas } & \multicolumn{2}{c|}{ Suco Artificial } \\
\cline { 2 - 9 } \multicolumn{1}{c|}{} & masc. & fem. & masc. & fem. & masc. & fem. & masc. & fem. \\
\hline EPU A & $27,49 \%$ & $41,67 \%$ & $70,76 \%$ & $54,41 \%$ & $39,18 \%$ & $43,14 \%$ & $32,16 \%$ & $30,39 \%$ \\
\hline EPU B & $30,46 \%$ & $40,20 \%$ & $74,62 \%$ & $74,02 \%$ & $53,30 \%$ & $57,35 \%$ & $28,43 \%$ & $34,80 \%$ \\
\hline EPU C & $35,61 \%$ & $38,24 \%$ & $53,03 \%$ & $57,35 \%$ & $46,21 \%$ & $41,91 \%$ & $40,15 \%$ & $33,82 \%$ \\
\hline EPA $\alpha$ & $13,33 \%$ & $25,53 \%$ & $43,33 \%$ & $19,15 \%$ & $51,67 \%$ & $59,57 \%$ & $28,33 \%$ & $23,40 \%$ \\
\hline EPA $\beta$ & $28,13 \%$ & $20,00 \%$ & $43,75 \%$ & $30,00 \%$ & $46,88 \%$ & $35,00 \%$ & $21,88 \%$ & $35,00 \%$ \\
\hline EPA $\chi$ & $40,00 \%$ & $21,74 \%$ & $52,00 \%$ & $47,83 \%$ & $64,00 \%$ & $47,83 \%$ & $32,00 \%$ & $43,48 \%$ \\
\hline
\end{tabular}

Observa-se que a água é mais ingerida no almoço por alunos do sexo masculino de escolas particulares de categoria $\chi$ e alunas de escolas públicas de categoria A e B.

O refrigerante é mais consumido por alunos e alunas das escolas públicas de categoria B.

O suco de frutas é preferido por alunos de escolas particulares; na população masculina a maior expressão é em escolas de categoria $\chi$ e na feminina em escolas de categoria $\alpha$.

A preferência por suco artificial está entre alunos do sexo masculino de escolas públicas de categoria $\mathrm{C}$ e entre as alunas de escolas particulares de categoria $\chi$. 


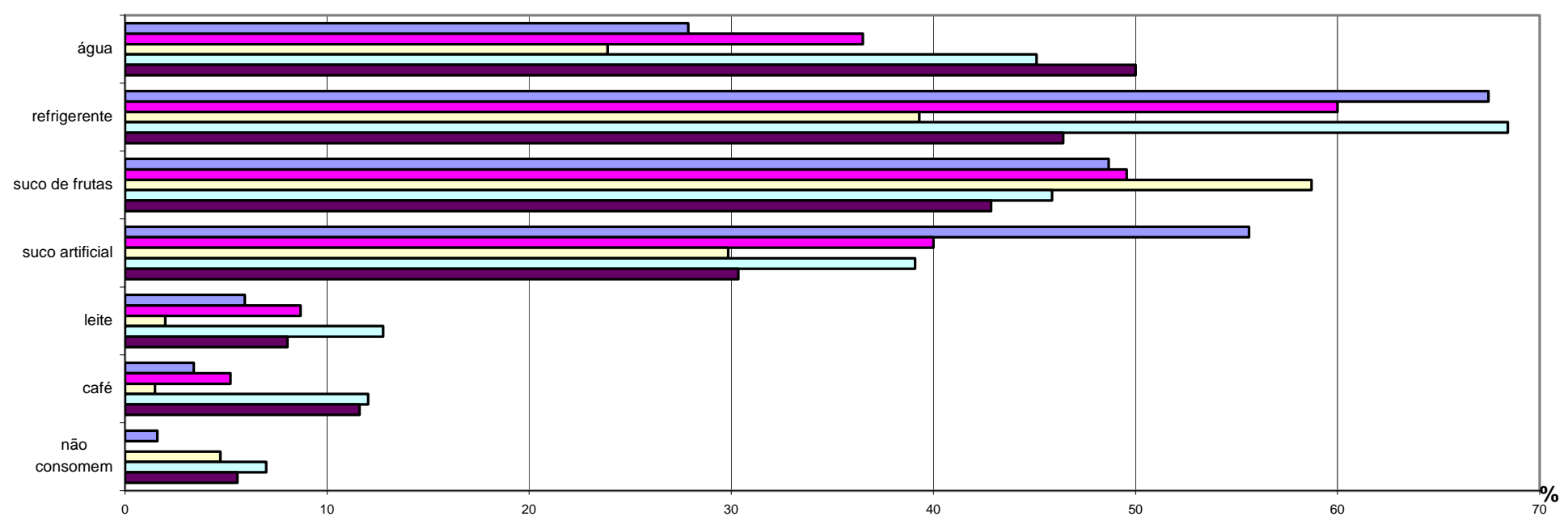

$\square$ Escolas Públicas de ensino regular diurno urbano $\quad \square$ Escolas Públicas de ensino regular rural

$\square$ Escolas Particulares de ensino regular diurno urbano $\quad \square$ Escolas Públicas de ensino regular noturno

$\square$ Escolas Públicas de educação supletiva noturno

Figura 10 Bebidas escolhidas para ingestão durante o almoço- Piracicaba(SP), 2004 


\begin{tabular}{|c|c|c|c|c|c|c|c|c|c|c|c|c|c|c|c|c|c|c|c|c|c|c|c|c|c|c|c|c|c|c|c|}
\hline \multirow[b]{2}{*}{ Bondials } & \multirow[b]{2}{*}{$\begin{array}{c}\text { 3as } \\
\text { masc Mace }\end{array}$} & \multirow{2}{*}{\multicolumn{4}{|c|}{ 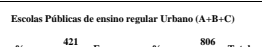 }} & \multirow[b]{2}{*}{$\%$} & \multicolumn{6}{|c|}{ 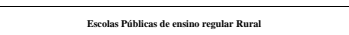 } & \multirow[b]{2}{*}{$\begin{array}{c}1200 \text { Masc } \\
\text { masc }\end{array}$} & \multicolumn{5}{|c|}{ 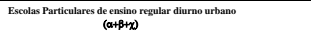 } & \multicolumn{6}{|c|}{ Escolas Paibilicas de entino regalar nouturno } & \multicolumn{7}{|c|}{ 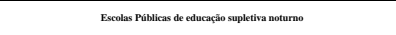 } \\
\hline & & $\%$ & & $\%$ & 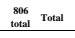 & & $\begin{array}{l}\frac{58}{38} \text { Max } \\
\text { mac }\end{array}$ & $\%$ & $\begin{array}{l}\substack{5 \pi \\
\text { tem }} \text { Fem } \\
\text { rem }\end{array}$ & $\%$ & 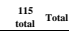 & $\%$ & & $\%$ & 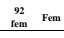 & $\%$ & 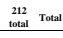 & $\%$ & 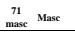 & $\%$ & 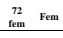 & $\%$ & 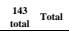 & $\%$ & $\begin{array}{l}\frac{58}{\text { sise }} \text { Maxc } \\
\text { mac }\end{array}$ & $\%$ & 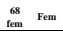 & $\%$ & & roal & $\%$ \\
\hline Consomen & 391 & 939,9 & 412 & 9,396 & 73 & sa:39 & ${ }_{s 8}$ & 100 & 57 & 100 & ${ }^{115}$ & ${ }_{100}^{100}(-3)(-3)$ & 11 & 9,500 & ${ }^{a 4}$ & 9,00 & ${ }_{201}^{20}$ & 9,81 & 6 & 95,7 & ${ }^{65}$ & ${ }_{90,28}$ & ${ }_{133}$ & 93,09 & si & 87,3 & ${ }^{6}$ & 89,21 & ${ }_{112}^{12}$ & & sa,so \\
\hline tam & ${ }_{103}^{103}$ & 27,09 & нв & $2,2,64$ & 22 & $2,7,87$ & ${ }^{23}$ & $33,60^{*}$ & 19 & ${ }_{3,33}$ & 2 & 3 & ${ }^{27}$ & 23,398 & ${ }^{21}$ & ${ }_{25}$ & 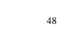 & $2,8,8$ & ${ }^{26}$ & 3024 & 3 & $52,3$. & со & ${ }^{45,11}$ & ${ }^{24}$ & $4,0,06$ & 32 & 52,65 & & 56 & so. \\
\hline retigereane & 28 & ro,3ase & ${ }^{200}$ & 6atal & 35 & $6,4,4$ & 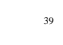 & ${ }_{62244^{\circ}}$ & s & $52,63$. & 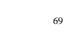 & ${ }^{60}$ & 33 & $45,30 \%$ & 26 & 30,055 & 9 & 303000 & ${ }^{65}$ & $\alpha_{6,19}$ & 46 & $r, \pi n$ & r & 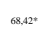 & ${ }_{25}$ & $a_{0,02}$ & ${ }^{27}$ & 4426. & & 52 & $4,63^{*}$ \\
\hline sorod fet mus & ${ }_{181}^{81}$ & $4,5,1 \mathbf{1}^{\circ}$ & 205 & 49,76. & 336 & $48,60^{\circ}$ & ${ }^{23}$ & $39,60^{*}$ & 3 & 5,95 & 57 & $40,5 \%$ & 62 & $52,99 \theta^{\circ}$ & ${ }_{46}$ & $5,7,60^{\circ}$ & 118 & $\operatorname{sen}, 7$. & 29 & $42,65^{\circ}$ & 32 & $4,2,3^{\circ}$ & 61 & $45,560^{\circ}$ & 23 & $45,10^{\circ}$ & 25 & $40,99-$ & & 48 & 42,860- \\
\hline sucranaticial & 208 & $78,22^{\circ}$ & ${ }_{143}$ & $34,77^{*}$ & 411 & $5,5,60^{\circ}$ & ${ }_{24}$ & $4,38^{\circ}$ & 22 & $38,60=$ & 46 & ${ }^{40}$ & 3 & $27,35^{\circ}$ & ${ }^{28}$ & ${ }_{3,3,3}$ & $\infty$ & $2,2,55^{\circ}$ & ${ }_{28}$ & 4.,1, & ${ }_{24}$ & 3092 & 52 & 3,10 & 19 & 37,25 & 15 & 24,59 & & ${ }^{34}$ & 30,36 \\
\hline blite & ${ }_{23}$ & Gou & ${ }_{24}^{24}$ & 5,83 & 4 & 5,93 & 6 & 10,34 & 4 & 7,02 & 10 & 8,70 & 4 & $3,2,2$ & 。 & 0,000 & 4 & 1,98 & 9 & 1324 & 8 & 12,31 & 17 & 12,78 & s & 9,80 & 4 & 6,56 & & ? & 8,4 \\
\hline atif & 16 & 420 & ${ }^{11}$ & 2.67 & ${ }_{27}$ & 3,40 & 3 & 5,17 & 3 & 5,26 & 6 & 5,22 & $=$ & 1,71 & 1 & 1,19 & 3 & 1,49 & , & 1324 & , & 10,7 & 16 & $12,2,3$ & 6 & 11,76 & ? & $1,1,+8$ & & 13 & 1.,61 \\
\hline Sisc consamen & 4 & 1,04 & , & 2.14 & ${ }_{13}$ & 1,61 & 。 & $0,0, \infty$ & . & $0,0,00$ & 。 & 0,00 & 3 & 2.50 & , & 7,61 & 10 & 4,72 & 3 & ${ }_{42,3}$ & , & 9,2 & 10 & 6,99 & 3 & 5,17 & 4 & $5,8,8$ & & , & 5,56 \\
\hline
\end{tabular}




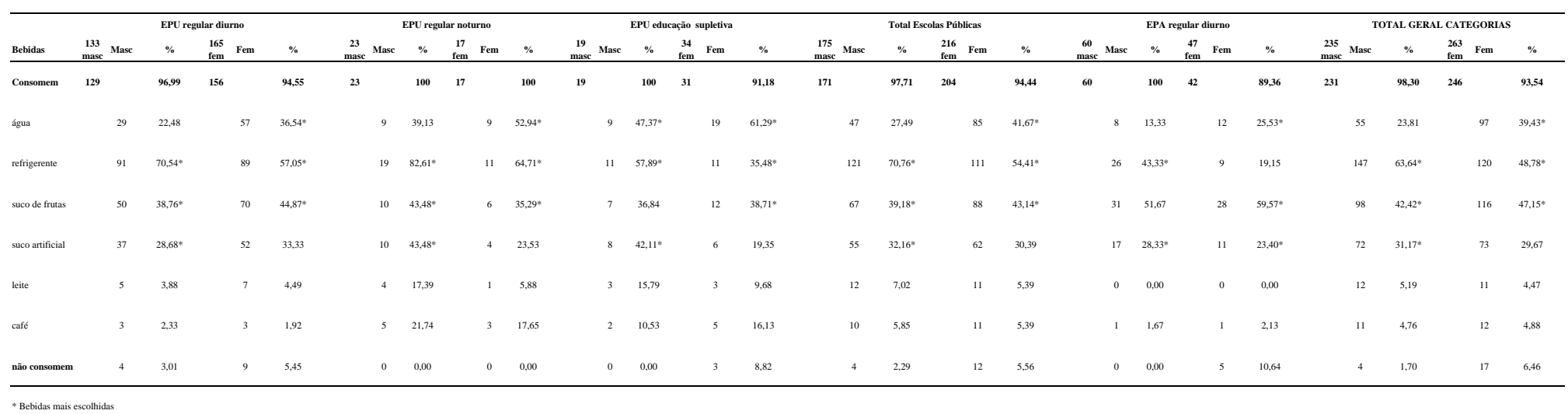


Tabela 6B. BEBBDAS ingeridas pelos alumos de escolas püblicas de categoria Be particulares $\beta$ (Zona Urbana) em horário de ALMoço. Piracicaba (SP), 2004

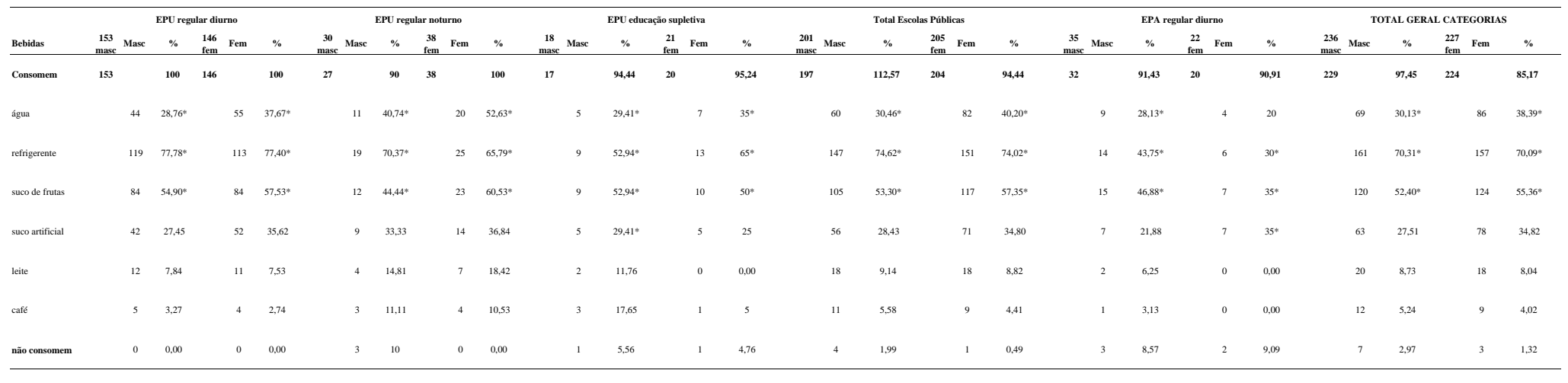


Tabela 6C. BEBIDAS ingeridas pelos alumos de escolas publicas de categoria Ce Particulares $x$ (Zona Urbana) em horário de ALMoço. Piracicaba (SP), 2004.

\begin{tabular}{|c|c|c|c|c|c|c|c|c|c|c|c|c|c|c|c|c|c|c|c|c|c|c|c|c|}
\hline \multirow[b]{2}{*}{ Benidas } & \multicolumn{4}{|c|}{ EPU regular diumo } & \multicolumn{4}{|c|}{ EPU regular noturno } & \multicolumn{4}{|c|}{ EPU educasăa supletiva } & \multicolumn{4}{|c|}{ Total Escolas Püblicas } & \multicolumn{4}{|c|}{ EPA regular diurno } & \multicolumn{4}{|c|}{ TOTAL GERAL CATEGORIAS } \\
\hline & ${ }_{\text {masc }}^{99}$ Masc & $\%$ & 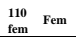 & $\%$ & $\begin{array}{c}18 \text { Masc } \\
\text { masc Masc }\end{array}$ & $\%$ & $\underset{\substack{15 \\
\text { fem }}}{\text { Fem }}$ & $\%$ & $\begin{array}{l}117 \text { Masc } \\
\text { masc }\end{array}$ & $\%$ & $\underset{\text { fem }}{11}$ Fem & $\%$ & $\begin{array}{l}{ }_{\text {mase }}^{134} \text { Masc } \\
\text { mase }\end{array}$ & $\%$ & $\begin{array}{l}\text { lise } \\
\text { fem }\end{array}$ & $\%$ & ${ }_{\text {masc }}^{25}$ Masc & $\%$ & 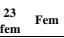 & $\%$ & $\begin{array}{l}{ }_{\text {masc }}^{159} \text { Masc } \\
\text { mas }\end{array}$ & $\%$ & 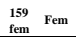 & $\%$ \\
\hline Consomem & 99 & 100 & ${ }_{110}$ & 100 & 18 & 100 & 15 & 100 & 15 & 88,24 & 11 & 100 & 132 & 98,51 & 136 & 100 & 25 & 100 & 23 & 100 & 157 & 98,74 & 159 & 100 \\
\hline agua & 31 & 31,31 & 41 & $37,27^{*}$ & 6 & 33,33 & 5 & ${ }_{13,16^{*}}$ & 10 & $66,67^{*}$ & 6 & $54,55^{\circ}$ & 47 & 35,61 & 52 & $38,24^{*}$ & 10 & $40^{\circ}$ & 5 & 21,74 & 57 & 36,31 & 57 & $35,55^{\circ}$ \\
\hline reffigerente & 58 & $58,59{ }^{\circ}$ & 65 & $59,99^{\circ}$ & 7 & $38,99^{*}$ & 10 & $26,32^{*}$ & 5 & 33,33 & 3 & $27,27^{*}$ & 70 & $53,03^{*}$ & 78 & $57,35^{\circ}$ & 13 & $52^{\circ}$ & 11 & $47,3^{*}$ & 83 & $52,87 \%$ & 89 & $55,97^{*}$ \\
\hline suco de frutus & 47 & $4,7,77^{*}$ & 51 & $46,36^{*}$ & 7 & $38,89^{*}$ & 3 & 7,89 & 7 & $46,67^{*}$ & 3 & $27,27^{\circ}$ & 61 & $46,21^{*}$ & 57 & $41,91^{*}$ & 16 & $6^{6 *}$ & 11 & $47,3^{*}$ & 77 & $49,044^{*}$ & 68 & $42,77^{\circ}$ \\
\hline suco artificial & 38 & $38,38^{*}$ & 39 & 35,45 & 9 & $50^{\circ}$ & 6 & $15,79 *$ & 6 & $40^{\circ}$ & 1 & 9,09 & 53 & $40,15^{*}$ & 46 & 33,82 & 8 & 32 & 10 & $43,48^{*}$ & 61 & $38,5^{*}$ & 56 & 35,22 \\
\hline letie & 6 & 6,06 & 6 & 5,45 & 1 & 5,56 & 0 & 0,000 & 0 & 0,000 & 1 & 9,99 & 7 & 5,30 & 7 & $\begin{array}{l}5,15 \\
\end{array}$ & 2 & 8 & 0 & 0,00 & 9 & 5,73 & 7 & ${ }^{4,40}$ \\
\hline caté & 8 & 8,08 & 4 & 3,64 & 1 & 5,56 & 0 & ${ }_{0,00}$ & 1 & 6,67 & 1 & 9,09 & 10 & 7,58 & 5 & 3,68 & 0 & 0,00 & 0 & 0,000 & 10 & 6,37 & 5 & 3,14 \\
\hline c consomemem & 0 & 0,00 & 0 & 0,000 & 0 & 0,000 & 0 & 0,00 & 2 & 11,7 & 0 & ${ }_{0,00}$ & 2 & 1,49 & 0 & ${ }_{0,00}$ & 0 & 0,00 & 0 & 0,00 & 2 & 1,26 & 0 & 0,00 \\
\hline
\end{tabular}

* Bebidas mis escollidins 


\subsubsection{Em horário de jantar}

Nas escolas públicas de ensino regular diurno, 91,69\% dos estudantes consomem algum tipo de bebida durante o jantar; no período noturno 93,71\%; na zona rural, 96,52\% e nas escolas particulares, 91,04\% ( Tabela 7).

É pequeno o percentual de estudantes que se abstêm do consumo de líquidos nessa refeição.

\subsubsection{Comparando-se zona urbana e rural}

Comparando-se as indicações feitas pelos alunos da rede regular de ensino de escolas públicas do período diurno em zona urbana, observa-se que o refrigerante é a bebida mais consumida no jantar (75,49\% pelos estudantes do sexo masculino e 68,58\% pelos do sexo feminino). Nas escolas particulares o suco natural tem maior expressão de consumo: $45,45 \%$ e 48,72\%, respectivamente entre estudantes do sexo masculino e feminino. Na zona rural também é o refrigerante a bebida mais consumida, sendo os percentuais de 65,52\% para o sexo masculino e 60,38\% para o feminino (Tabela 7).

A preferência em zona urbana e rural é por suco natural ao artificial em escolas públicas e particulares, exceto entre os estudantes do sexo masculino de zona urbana da rede regular de ensino público que consomem 73,26\% de suco artificial contra 43,18\% de suco natural de frutas (Tabela 7).

\subsubsection{Comparando-se por período de funcionamento das escolas de zona urbana}

A água é consumida com mais destaque no jantar entre alunos do sexo masculino e feminino do período noturno, mais na rede de educação supletiva que na de educação regular; no período diurno a bebida tem mais destaque entre alunas das escolas particulares com 29,49\% (Tabela 7).

O refrigerante é mais consumido por estudantes do período noturno que do diurno e mais por alunos da rede regular de ensino do que pelos da educação supletiva; é menos consumido por alunos da rede particular no período diurno (Figura 11). 
O maior consumo de suco de frutas está entre os alunos do período diurno de escolas públicas em zona rural, seguidos pelos da rede particular de ensino; o menor está entre alunos da educação supletiva em período noturno (Gráfico 11). Os de zona rural os consomem mais, provavelmente pela fartura de frutas, mas, na zona urbana há maiores percentuais de consumo entre alunos da rede particular de ensino, possivelmente pelo alto custo.

Quanto ao suco artificial, é mais ingerido no jantar por alunos do período diurno em escolas públicas de zona urbana e rural; é menos bebido por alunos da rede particular de ensino; no período noturno é mais consumido por alunos da rede regular que da educação supletiva (Figura 11).

\subsubsection{Comparando-se por modalidade de curso}

A água é mais consumida entre alunos da educação supletiva que entre os da rede regular de ensino.

O refrigerante, ao contrário, é mais consumido entre alunos da rede regular de ensino.

O suco de frutas é menos consumido por alunos da educação supletiva no jantar; é mais consumido, como já mencionado, por alunos de zona rural onde há abundância de frutas e por alunos da rede particular de ensino na zona urbana.

O suco artificial é mais consumido entre alunos da rede regular de ensino.

\subsubsection{Comparando-se por sexo}

O consumo de água no jantar é maior entre a população feminina em todas as categorias de escolas (Tabela 7).

Com o refrigerante acontece o oposto: é mais ingerido pela população masculina (Tabela 7).

Os alunos do sexo masculino que estudam em período noturno, detêm maior percentual de ingestão de suco natural que suas colegas; no período diurno, na zona 
rural, o percentual maior está com o sexo masculino e na zona urbana com a população feminina (Tabela 7).

O suco artificial é ingerido em maior percentual por estudantes do sexo masculino no período noturno, seja na rede regular ou da educação supletiva; no período diurno, em zona urbana, o maior percentual está com a população masculina nas escolas públicas e com a população feminina nas escolas particulares; na zona rural o maior percentual de ingestão de suco artificial no jantar está com a população feminina (Tabela 7).

\subsubsection{Comparando-se por categoria de escolas (Tabelas 7A, 7B, 7C)}

\begin{tabular}{|c|c|c|c|c|c|c|c|c|}
\cline { 2 - 8 } \multicolumn{1}{c|}{} & \multicolumn{2}{c|}{ Água } & \multicolumn{2}{c|}{ Refrigerante } & \multicolumn{2}{c|}{ Suco de Frutas } & \multicolumn{2}{c|}{ Suco Artificial } \\
\cline { 2 - 9 } \multicolumn{1}{c|}{} & masc. & fem. & masc. & fem. & masc. & fem. & masc. & fem. \\
\hline EPU A & $27,54 \%$ & $35,23 \%$ & $70,06 \%$ & $55,44 \%$ & $37,72 \%$ & $32,64 \%$ & $31,74 \%$ & $29,02 \%$ \\
\hline EPU B & $34,23 \%$ & $40,09 \%$ & $82,88 \%$ & $72,35 \%$ & $50,45 \%$ & $50,69 \%$ & $28,38 \%$ & $33,18 \%$ \\
\hline EPU C & $36,22 \%$ & $39,19 \%$ & $56,69 \%$ & $69,17 \%$ & $42,52 \%$ & $45,83 \%$ & $40,16 \%$ & $43,33 \%$ \\
\hline EPA $\alpha$ & $17,65 \%$ & $27,03 \%$ & $56,86 \%$ & $29,73 \%$ & $49,02 \%$ & $62,16 \%$ & $35,29 \%$ & $29,73 \%$ \\
\hline EPA $\beta$ & $36,67 \%$ & $31,82 \%$ & $55,67 \%$ & $27,27 \%$ & $46,67 \%$ & $31,82 \%$ & $50,00 \%$ & $48,95 \%$ \\
\hline EPA $\chi$ & $33,33 \%$ & $31,58 \%$ & $45,83 \%$ & $57,89 \%$ & $45,83 \%$ & $42,11 \%$ & $33,33 \%$ & $36,84 \%$ \\
\hline
\end{tabular}

O maior consumo de água no jantar está entre alunos do sexo masculino de escolas particulares de categoria $\beta$ e entre alunas de escolas públicas de categoria B.

O refrigerante registra maior percentual de ingestão entre a população masculina e feminina de escolas públicas de categoria B.

O suco natural de frutas é mais ingerido por estudantes do sexo masculino de escolas públicas de categoria B e do sexo feminino de escolas particulares de categoria $\alpha$.

Quanto ao suco artificial, é mais ingerido no jantar, pela população masculina e feminina de escolas particulares de categoria $\beta$. 


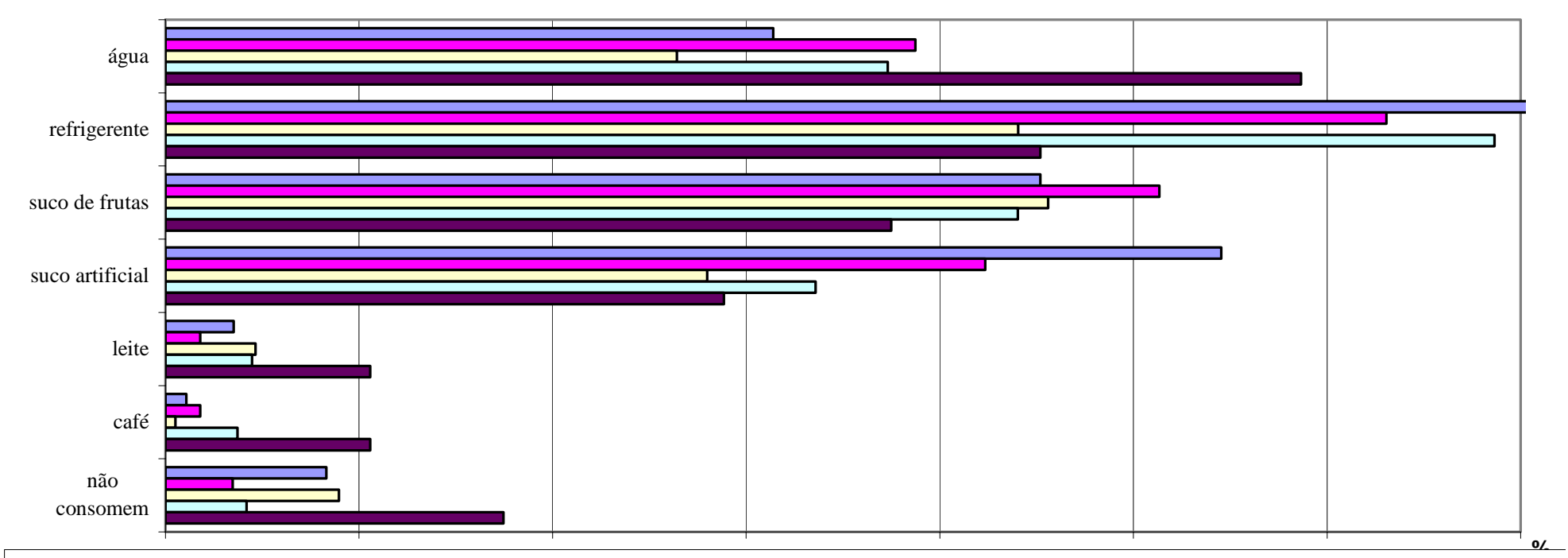

$\square$ Escolas Públicas de ensino regular diurno uubano

口Escolas Públicas de ensino regular rural

$\square$ Escolas Particulares de ensino regular diurno urbano

$\square$ Escolas Públicas de ensino regular noturno urbano

—Escolas Públicas de educação supletiva urbana

Figura 11 Bebidas escolhidas para ingestão durante o jantar Piracicaba (SP), 2004 


\begin{tabular}{|c|c|c|c|c|c|c|c|c|c|c|c|c|c|c|c|c|c|c|c|c|c|c|c|c|c|c|c|c|c|c|c|}
\hline \multirow[b]{2}{*}{ Bacialas } & \multicolumn{6}{|c|}{ 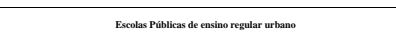 } & \multicolumn{6}{|c|}{ 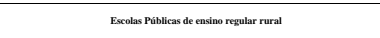 } & \multicolumn{7}{|c|}{ Escolas Particialares de ensino regalar diuma urtano } & \multicolumn{6}{|c|}{ 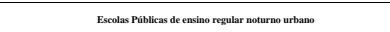 } & \multicolumn{6}{|c|}{ 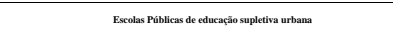 } \\
\hline & 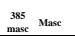 & $\%$ & 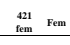 & $\%$ & 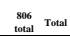 & $\%$ & 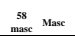 & $\%$ & $\begin{array}{lll}57 \\
\mathrm{tem}\end{array}$ & $\%$ & $\begin{array}{c}115 \\
\text { total } \\
\text { toral }\end{array}$ & $\%$ & 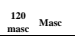 & $\%$ & $\underset{\substack{\text { sem } \\
\text { tem }} \text { rem }}{2}$ & $\%$ & & Toat & $\%$ & 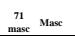 & * & $\begin{array}{c}\underbrace{2}_{\text {tem }} \\
\text { tem }\end{array}$ & $\%$ & 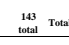 & $\%$ & 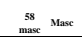 & $*$ & 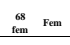 & $\%$ & 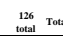 & $\%$ \\
\hline Comomem & sso & ${ }_{93,25}$ & 390 & 9022 & 79 & 91,69 & $\mathrm{sg}$ & ${ }_{100}^{100}$ & ${ }_{53}$ & 2,28 & ${ }^{111}$ & $9,5,2$ & 110 & 91,67 & ${ }_{78}$ & $s, 2$ & ${ }^{103}$ & & $9,0,9$ & $\approx$ & 94,37 & $"$ & 93,66 & 13 & 2,3, & 51 & 87,93 & $s$ & 77,94 & 104 & 82,54 \\
\hline \&qua & ${ }_{101}^{101}$ & 28,13 & ${ }^{131}$ & $34,47-3$ & 232 & 31,39 & 20 & 34,48 & ${ }^{23}$ & 4,300 & ${ }_{43}$ & 30,7 & ${ }_{28} \mathrm{~B}$ & $2,5,5$ & ${ }_{23}$ & 29,49 & & ${ }_{51}$ & 26,42 & 25 & $33: 31$ & 25 & 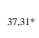 & 50 & 373 & 26 & ${ }_{50,9 a^{*}}$ & 35 & $6,0, a+4$ & ${ }_{61}$ & $58,5.5$. \\
\hline entiberement & ${ }^{21}$ & $75,49^{*}$ & ${ }^{261}$ & arsese & 32 & 1.,90. & 38 & $6,5,52^{\circ}$ & ${ }^{32}$ & 60,39 & 70 & ब3,66 & 57 & $5,1,22^{2}$ & ${ }^{28}$ & $35, \infty$ & & ${ }^{85}$ & 4,aser & as & ${ }^{1,6 \sigma^{*}}$ & " & $6,500^{\circ}$ & 92 & 60,6 & 27 & 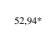 & ${ }^{20}$ & 37,24 & 4 & ${ }_{6,59}$ \\
\hline suroded thums & 155 & $43,18^{*}$ & 179 & 4,11 & 34 & $45,200^{*}$ & 31 & $53,45^{*}$ & 26 & 49,96 & 57 & $51,33^{\circ}$ & 50 & $45,45^{\circ}$ & ${ }_{38}$ & $4 \mathrm{~B}, 7$ & & 88 & $45,60^{\circ}$ & 33 & ${ }_{49,25^{*}}$ & 26 & 3 & 59 & $4,0.0$ & 21 & $44,10^{*}$ & 18 & $33966^{\circ}$ & 39 & 37,500 \\
\hline surosantifical & ${ }_{263}$ & $73,26^{\circ}$ & 100 & 36,84 & 403 & $54,53^{*}$ & 22 & $3,93=$ & 25 & $4,7,17$ & 47 & ${ }_{22,2,3}^{*}$ & 31 & $28,18^{\circ}$ & ${ }^{23}$ & $2,9,4$ & & 54 & $2,7,9 a^{\circ}$ & 27 & $40,30 \%$ & 18 & 26,87 & ${ }_{45}$ & $3,3.5$ & 17 & 33,33 & 13 & 24,53 & 30 & ${ }_{28,95}$ \\
\hline thite & ${ }^{17}$ & 4,4 & 9 & 2,37 & ${ }_{26}^{26}$ & $3,5,2$ & 1 & $1,2,2$ & 1 & $1, .80$ & $=$ & 1,00 & ${ }^{6}$ & 5,45 & 3 & $3,8,5$ & & o & 4,66 & 1 & 1,49 & 5 & 7,46 & ${ }^{6}$ & 4 & 5 & 9,900 & 6 & 11,32 & " & 10,58 \\
\hline cate & 6 & 1,67 & $=$ & 0,38 & 8 & 1,08 & $=$ & 3,5 & 。 & 0,00 & 2 & 1,00 & 1 & 年, & 。 & 0,0 & & 1 & 0,52 & 3 & 4,4 & 2 & 2,99 & ${ }^{5}$ & 3,7 & ${ }^{6}$ & 11,76 & 5 & 9,3 & " & 10,58 \\
\hline nais consanem & 26 & 6,75 & ${ }_{41}$ & 9,74 & 67 & 8,31 & 。 & $0,0,0$ & 4 & $\begin{array}{r}7,02 \\
\end{array}$ & 4 & 3,48 & ${ }_{10}^{10}$ & ${ }_{8,33}$ & , & 9,8 & & 19 & ${ }_{8,6}$ & 4 & 5,69 & 2 & 2,78 & 6 & 4,7 & , & ${ }_{12,07}$ & 15 & 22,46 & 22 & $\begin{array}{l}17,46 \\
\end{array}$ \\
\hline
\end{tabular}

- Bebidis mals secolitidas 
Tabela 7A. BEBDDAS ingeridas pelos alunos de escolas publicica de categoria A e particulares $\alpha$, (Zona Urbana) em horário de JANTAR. Piracicaba (SP), 2004

\begin{tabular}{|c|c|c|c|c|c|c|c|c|c|c|c|c|c|c|c|c|c|c|c|c|c|c|c|c|}
\hline \multirow[b]{2}{*}{ Bebidas } & \multicolumn{4}{|c|}{ EPU regular diurno } & \multicolumn{4}{|c|}{ EPU regular noturno } & \multicolumn{4}{|c|}{ EPU ed. Supletiva } & \multicolumn{4}{|c|}{ Total Escolas Públicas } & \multicolumn{4}{|c|}{ EPA regular diurno } & \multicolumn{4}{|c|}{ TOTAL GERAL CATEGORIAS } \\
\hline & 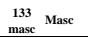 & $\%$ & $\begin{array}{l}\text { fem } \\
\text { fem }\end{array}$ & $\%$ & $\begin{array}{l}{ }_{\text {masc }}^{23} \text { Masc } \\
\text { masc }\end{array}$ & $\%$ & $\begin{array}{ll}17 & 17 \\
\text { tem } & \text { Fem }\end{array}$ & $\%$ & $\begin{array}{l}19 \\
\text { masc Masc } \\
\text { mate }\end{array}$ & $\%$ & $\begin{array}{l}\text { fem } \\
\text { firm }\end{array}$ & $\%$ & $\begin{array}{l}{ }_{\text {masc }}^{175} \text { Masc } \\
\text { Mas }\end{array}$ & $\%$ & $\begin{array}{l}\text { It6 } \\
\text { fem }\end{array}$ & $\%$ & $\begin{array}{c}{ }_{\text {masc }}^{60} \text { Masc } \\
\text { masc }\end{array}$ & $\%$ & $\begin{array}{l}47 \text { fem } \\
\text { Fem }\end{array}$ & $\%$ & 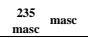 & $\%$ & $\begin{array}{l}263 \\
\text { fem }\end{array}$ & $\%$ \\
\hline Consomem & 127 & 95,49 & 149 & 90,30 & 23 & 100 & 15 & 88,24 & 17 & 89,47 & 29 & 85,29 & 167 & & 193 & & 51 & & 37 & & 218 & & 230 & \\
\hline água & 27 & 21,26 & 41 & 27,52 & 9 & $3,13^{*}$ & 7 & $46,67^{*}$ & 10 & $58,822^{*}-100$ & 20 & 68979 & 46 & 27,54 & 68 & ${ }^{35,23^{*}}$ & 9 & 17,65 & ${ }_{10}$ & 27,03 & 55 & 25,23 & 78 & ${ }^{33,91^{*}}$ \\
\hline refrigerente & 87 & $68,50^{*}$ & 88 & $59,06^{*}$ & 17 & $73,91^{*}$ & 10 & $66,67^{*}$ & 13 & $76,47^{*}$ & 9 & 31,03 & 117 & ${ }^{70,06^{*}}$ & 107 & $55,44^{*}$ & 29 & 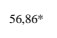 & ${ }^{11}$ & $29,73^{*}$ & 146 & $66,97^{*}$ & 118 & ${ }_{51,30^{*}}$ \\
\hline suco de fruas & 45 & $35,43^{*}$ & 50 & $33,56^{*}$ & 11 & $4,7,83^{*}$ & 4 & 26,67 & 7 & 44,18 & 9 & 31,03. & 63 & $37,72^{*}$ & 63 & $32,64^{*}$ & 25 & $4,92^{*}$ & 23 & $62,6^{\circ}$ & 88 & $40,37^{*}$ & 86 & $37,399^{*}$ \\
\hline succ artificial & 36 & $28,35^{*}$ & 46 & $30,87^{*}$ & 8 & 34,78 & 5 & $33,33^{*}$ & 9 & $52,94^{*}$ & 5 & 17,24 & 53 & $31,74^{*}$ & 56 & 29,02 & 18 & $3,2,9^{*}$ & ${ }^{11}$ & $29,73^{\circ}$ & 71 & $32,57^{*}$ & 67 & 2,13 \\
\hline leite & 3 & 2,36 & 3 & 2,01 & 0 & 0,00 & 1 & 6,67 & 2 & 11,76 & ${ }^{3}$ & 10,34 & 5 & 2,99 & 7 & 3,63 & 3 & 5,88 & ${ }^{2}$ & 5,41 & 8 & 3,67 & 9 & 3.91 \\
\hline cate & 0 & 0,00 & 0 & 0,00 & 1 & 4,35 & 1 & 6,67 & 2 & 11,76 & 3 & 10,34 & 3 & 1,80 & 4 & 2,07 & 1 & 1,96 & 0 & 0,00 & 4 & 1,83 & 4 & 1,74 \\
\hline não consomem & 6 & 4,51 & 16 & 9,70 & 0 & 0,00 & ${ }^{2}$ & 11,76 & 2 & 10,53 & 5 & 16,13 & 8 & 4,57 & 23 & 10,65 & 4 & 6,67 & 5 & 10,64 & 12 & 5,11 & ${ }^{28}$ & 10,65 \\
\hline
\end{tabular}




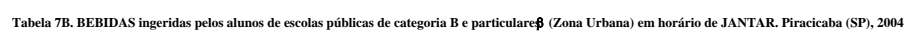

\begin{tabular}{|c|c|c|c|c|c|c|c|c|c|c|c|c|c|c|c|c|c|c|c|c|c|c|c|c|}
\hline \multirow[b]{2}{*}{ Bectidas } & \multirow[b]{2}{*}{ 每3sc Masc } & \multicolumn{3}{|c|}{ EPU regular diumo } & \multicolumn{4}{|c|}{ EPU regular noturno } & \multicolumn{4}{|c|}{ EPU ed. Supletiva } & \multicolumn{4}{|c|}{ Total Escolas Pábilicas } & \multicolumn{4}{|c|}{ EPA regular diurno } & \multicolumn{4}{|c|}{ TOTAL GERAL CATEGORIAS } \\
\hline & & $\%$ & 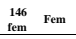 & $\%$ & masc Masc & $\%$ & $\begin{array}{l}722 \\
\text { tem }\end{array}$ & $\%$ & 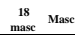 & $\%$ & $\underset{\text { tem }}{21}$ Fem & $\%$ & 丝ase Mase & $\%$ & $\begin{array}{l}\text { lem } \\
\text { tem }\end{array}$ & $\%$ & $\begin{array}{l}35 \\
\text { masc Masc } \\
\text { mase }\end{array}$ & $\%$ & $\begin{array}{l}\text { lem } \\
\text { tem } \\
\text { Fem }\end{array}$ & $\%$ & 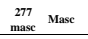 & $\%$ & $\begin{array}{l}\text { 261 } \\
\text { tem } \\
\text { Fem }\end{array}$ & $\%$ \\
\hline Consomem & ${ }_{137}$ & 89,54 & 134 & 91,78 & 67 & 94,37 & 65 & 90,28 & 18 & 0 & 18 & 52,94 & 222 & 91,74 & 217 & 90,79 & 30 & 85,71 & 22 & 100 & 252 & & ${ }^{239}$ & \\
\hline Sg gala & 42 & $30,66^{*}$ & 53 & $39,55^{\circ}$ & 25 & 37,31 & 25 & $38,46^{*}$ & 9 & ${ }^{50 *}$ & 9 & 50* & 76 & $34,23^{*}$ & 87 & $40,99+$ & ${ }_{11}^{11}$ & $36,67 *$ & ? & $3,1,2^{*}$ & 87 & $34,52^{*}$ & ${ }_{94}$ & 39,33 \\
\hline refrigerente & 127 & $92,70^{*}$ & 104 & ${ }_{77,61^{*}}$ & 48 & $7,66^{*}$ & ${ }_{44}^{4}-3 x-30$ & $67,69^{*}$ & 9 & $50 *$ & 9 & ${ }^{50 *}$ & ${ }_{184}$ & 82,88** & 157 & $72,35^{*}$ & 17 & $56,67^{*}$ & ${ }^{6}$ & $27,27^{*}$ & 201 & $79,76^{*}$ & 163 & 68,20 \\
\hline surco de fruas & 69 & $50,36^{*}$ & 77 & $57,46^{*}$ & ${ }^{33}$ & $49,25^{*}$ & 26 & ${ }^{40}$ & 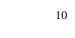 & $55,56^{\circ}$ & 7 & $38,99^{4}$ & ${ }_{112}$ & $50,45^{\circ}$ & 110 & 50,99* & ${ }_{14}$ & $46,67^{*}$ & ? & $31,2^{*}$ & 126 & ${ }^{50 *}$ & ${ }_{117}^{17}$ & ${ }_{48,95}$ \\
\hline succo artificial & ${ }_{31}$ & 22,63 & 47 & 35,07 & 27 & $40,30^{*}$ & 18 & 27,69 & 5 & 27,78 & 7 & $38,99 *$ & 63 & 28,38 & 72 & 33,18 & 5 & 16,67 & 5 & 22,73 & 68 & 26,98 & 77 & 32,2 \\
\hline letie & 6 & 4,38 & 5 & 3,33 & 1 & 1,49 & 5 & 7,69 & 1 & 5,56 & 2 & 11,11 & 8 & 3,60 & 12 & 5,53 & 2 & 6,67 & 。 & 0,00 & 10 & 3,97 & 12 & 5,02 \\
\hline cate & 1 & 0,73 & 1 & 0,75 & 2 & 2,99 & 2 & 3,08 & 2 & 1,11 & 1 & 5,56 & 5 & 2,25 & 4 & 1,84 & 0 & 0,000 & $\circ$ & 0,00 & 5 & 1,98 & 4 & 1,67 \\
\hline näa c consomem & 3 & 1,96 & 12 & 8,22 & 4 & 5,63 & 7 & 9,72 & 0 & 0,000 & ${ }^{3}$ & 1429 & ? & 2,89 & 22 & 9,21 & 5 & 14,29 & ${ }^{\circ}$ & 0,00 & ${ }_{12}$ & 4,33 & 22 & 8,43 \\
\hline
\end{tabular}


Tabela 7C. BEBDAS ingeridas pelos alunos de escolas públicas de categoria C e particulares $\chi$ ( Zona Urbana) em horário de JANTAR. Piracicaba (SP), 2004.

\begin{tabular}{|c|c|c|c|c|c|c|c|c|c|c|c|c|c|c|c|c|c|c|c|c|c|c|c|c|}
\hline \multirow[b]{2}{*}{ Bebidas } & \multicolumn{4}{|c|}{ EPU regular diurno } & \multicolumn{4}{|c|}{ EPU regular noturno } & \multicolumn{4}{|c|}{ EPU educaçăo supletiva } & \multicolumn{4}{|c|}{ Total Escolas Públicas } & \multicolumn{4}{|c|}{ EPA regular diurno } & \multicolumn{4}{|c|}{ TOTAL GERAL CATEGORIAS } \\
\hline & $\begin{array}{l}99 \\
\text { masc Masc } \\
\text { Mas }\end{array}$ & $\%$ & $\begin{array}{l}\mathbb{f e m}_{\mathrm{fem}}^{110} \\
\mathrm{Fen}\end{array}$ & $\%$ & $\begin{array}{c}18 \\
\text { masc Masc }\end{array}$ & $\%$ & $\begin{array}{l}15 \\
\text { fem }\end{array}$ & $\%$ & $\begin{array}{c}17 \\
\text { masc Masc }\end{array}$ & $\%$ & $\begin{array}{l}{ }_{\text {fem }}^{11} \\
\text { Fem }\end{array}$ & $\%$ & $\begin{array}{c}134 \\
\text { masc Masc }\end{array}$ & $\%$ & $\begin{array}{c}{ }^{136} \\
\text { fem }\end{array}$ & $\%$ & ${ }_{\text {masc }}^{25}$ Masc & $\%$ & $\begin{array}{l}\underset{\text { fem }}{23} \\
\text { Fem }\end{array}$ & $\%$ & $\begin{array}{c}159 \\
\text { masc Masc }\end{array}$ & $\%$ & $\begin{array}{c}159 \\
\text { fem }\end{array}$ & $\%$ \\
\hline Consomem & ${ }_{95}$ & 95,96 & 97 & 88,18 & 17 & 94,44 & 15 & 100 & 15 & & 8 & & ${ }_{127}$ & & 120 & & 24 & & 19 & & 151 & & 139 & \\
\hline ağua & 32 & 33,68 & 37 & 38,14 & 7 & $41,18^{*}$ & ${ }^{4}$ & $26,67^{*}$ & 7 & $46,67^{*}$ & 6 & $7^{*}$ & 46 & 36,22 & 47 & 39,17 & 8 & ${ }^{33,33^{*}}$ & 6 & 31,58 & 54 & 35,76 & 53 & 38,1 \\
\hline refigigerente & 57 & $60^{*}$ & 69 & ${ }^{71,13^{*}}$ & 10 & $58,82^{*}$ & $1:$ & $80^{*}$ & 5 & $33,33^{*}$ & 2 & $25^{*}$ & 72 & $56,69^{*}$ & 83 & 69,17 & ${ }^{11}$ & $45,83^{*}$ & ${ }_{11}^{11}$ & $57,89^{\circ}$ & 83 & $54,97^{*}$ & 94 & 67,63 \\
\hline suco de frutas & ${ }^{41}$ & $43,16^{*}$ & 52 & ${ }_{53,61^{*}}$ & 9 & $52,94^{*}$ & 1 & 6,67 & 4 & $26,67 *$ & 2 & $25^{*}$ & 54 & $42,52^{*}$ & 55 & $45,83^{\circ}$ & ${ }^{11}$ & $45,83^{*}$ & 8 & $42,11^{*}$ & 65 & $43,05^{*}$ & 63 & 45,32 \\
\hline succ artificial & 41 & $43,16^{*}$ & 47 & $48,45^{*}$ & 7 & $44,18^{*}$ & . & $26,67^{*}$ & 3 & 20 & 1 & 12,50 & 51 & $40,16^{*}$ & 52 & $43,33^{\circ}-1-3$ & 8 & ${ }_{33,33^{*}}$ & 7 & $36,84^{*}$ & 59 & $39,07 *$ & 59 & 42,45 \\
\hline letite & 8 & 8,42 & 1 & 1,03 & 1 & 5,88 & se & 0,00 & 2 & 13,33 & 1 & 12,50 & ${ }^{11}$ & 8,66 & 2 & 1,67 & 1 & 4,17 & 1 & 5,26 & 12 & 7,95 & 3 & 2,16 \\
\hline cafte & 5 & 5,26 & 1 & 1,03 & 1 & 5,88 & s. & 0,00 & 2 & 13,33 & 1 & 12,50 & 8 & 6,30 & 2 & 1,67 & 0 & 0,00 & 0 & 0,00 & 8 & 5,30 & 2 & 1,44 \\
\hline não consomem & 4 & 4,04 & 13 & 11,82 & 1 & 5,56 & s & 0,00 & 2 & 11,76 & 3 & 27,27 & 7 & 5,22 & 16 & 11,76 & 1 & 4,00 & 4 & 17,39 & 8 & 5,03 & 20 & 12,58 \\
\hline
\end{tabular}

* Bebidas mais secollidas 


\subsection{Influências na formação dos hábitos alimentares}

Na opinião dos concluintes do ensino fundamental da zona rural e em todas as categorias de escolas públicas da zona urbana da rede regular de ensino diurno e também nas escolas particulares das categorias $\alpha \varepsilon \beta$ é a família o maior fator de influência na formação de hábitos alimentares (Tabelas 8 e 9).

Entre os alunos do sexo masculino da rede regular de ensino noturno há uma equiparação entre escola e família na opinião quanto à formação dos hábitos alimentares; entre as alunas do supletivo, a escola é apontada como o maior fator de influência. É interessante lembrar que a maioria desses alunos vêm de classes menos favorecidas sócio e culturalmente, onde, muitas vezes, a escolaridade dos pais é inferior às suas, sendo que em suas casas nem sempre podem contar com jornais e revistas que pudessem trazer-lhes outras orientações.

Nas escolas particulares de categoria $\chi$, portanto as menos dispendiosas, os rapazes apontam a escola como o maior fator de influência e as moças a TV. Esses adolescentes, muito provavelmente, não estão engajados no mercado do trabalho; é comum as alunas se ocuparem com afazeres domésticos e assistirem à TV nas horas vagas e os rapazes se dedicarem mais a atividades esportivas; pode ser que esteja aí a explicação das opiniões emitidas, sobretudo entre as alunas. 
Tabela 8. $\mathbf{N}^{\circ}$ de opiniões dos alunos quanto ao fator que mais interferiu na formação de seus hábitos alimentares. Piracicaba (SP), 2004

\begin{tabular}{|c|c|c|c|c|c|c|c|c|c|c|c|c|}
\hline & \multicolumn{2}{|c|}{ EPU regular diurno } & \multicolumn{2}{|c|}{ EPU regular noturno } & \multicolumn{2}{|c|}{ EPU supletivo } & \multicolumn{2}{|c|}{ EPU regular rural } & \multicolumn{2}{|c|}{ EPU TOTAL } & \multicolumn{2}{|c|}{ EPA regular diurno } \\
\hline & $\begin{array}{c}385 \\
\text { masc } \\
\end{array}$ & $\begin{array}{l}421 \\
\text { fem } \\
\end{array}$ & $\begin{array}{c}71 \\
\text { masc } \\
\end{array}$ & $\begin{array}{c}72 \\
\text { fem } \\
\end{array}$ & $\begin{array}{c}54 \\
\text { masc } \\
\end{array}$ & $\begin{array}{r}66 \\
\text { fem } \\
\end{array}$ & $\begin{array}{c}63 \\
\text { masc } \\
\end{array}$ & $\begin{array}{c}64 \\
\text { fem } \\
\end{array}$ & $\begin{array}{c}573 \\
\text { masc }\end{array}$ & $\begin{array}{r}623 \\
\text { fem } \\
\end{array}$ & $\begin{array}{c}120 \\
\text { masc }\end{array}$ & $\begin{array}{c}92 \\
\text { fem }\end{array}$ \\
\hline Escola & 80 & 112 & $24^{*}$ & 22 & 18 & $18^{*}$ & 13 & 13 & 135 & 165 & 37 & 15 \\
\hline Família & $184^{*}$ & $211^{*}$ & $24^{*}$ & $24^{*}$ & $20^{*}$ & 14 & $29 *$ & $33^{*}$ & $257^{*}$ & $282^{*}$ & $58^{*}$ & $55^{*}$ \\
\hline $\mathrm{TV}$ & 117 & 93 & 21 & 19 & 13 & 14 & 14 & 11 & 165 & 137 & 16 & 14 \\
\hline Brancos e nulos & 4 & 5 & 2 & 7 & 3 & 20 & 7 & 7 & 16 & 39 & 9 & 8 \\
\hline
\end{tabular}

* Maior $n^{\circ}$ de opiniões 
Tabela 9. Opiniões quanto aos fatores que mais influíram na formação dos hábitos alimentares em alunos da rede regular de ensino diurno de zona urbana por categoria de escolas. Piracicaba (SP), 2004

\begin{tabular}{|c|c|c|c|c|c|c|c|c|c|c|c|c|}
\hline & \multicolumn{6}{|c|}{ Escolas Públicas } & \multicolumn{6}{|c|}{ Escolas Particulares } \\
\hline & \multicolumn{2}{|c|}{ Categoria A } & \multicolumn{2}{|c|}{ Categoria B } & \multicolumn{2}{|c|}{ Categoria C } & \multicolumn{2}{|c|}{ Categoria $\alpha$} & \multicolumn{2}{|c|}{ Categoria $\beta$} & \multicolumn{2}{|c|}{ Categoria $\chi$} \\
\hline & $\begin{array}{c}133 \\
\text { masc } \\
\end{array}$ & $\begin{array}{l}165 \\
\text { fem } \\
\end{array}$ & $\begin{array}{c}153 \\
\text { masc } \\
\end{array}$ & $\begin{array}{l}146 \\
\text { fem } \\
\end{array}$ & $\begin{array}{c}99 \\
\text { masc } \\
\end{array}$ & $\begin{array}{l}110 \\
\text { fem } \\
\end{array}$ & $\begin{array}{c}60 \\
\text { masc } \\
\end{array}$ & $\begin{array}{r}47 \\
\text { fem }\end{array}$ & $\begin{array}{r}35 \\
\text { masc } \\
\end{array}$ & $\begin{array}{c}22 \\
\text { fem }\end{array}$ & $\begin{array}{c}25 \\
\text { masc } \\
\end{array}$ & $\begin{array}{r}23 \\
\text { fem }\end{array}$ \\
\hline Escola & 24 & 45 & 44 & 41 & 12 & 13 & 15 & 4 & 13 & 4 & $9 *$ & 7 \\
\hline Família & $59 *$ & $63 *$ & $74^{*}$ & $92 *$ & $51^{*}$ & $56^{*}$ & $34 *$ & $35^{*}$ & $17 *$ & $13^{*}$ & 7 & 7 \\
\hline TV & 44 & 33 & 47 & 38 & 26 & 22 & 5 & 4 & 3 & 1 & 8 & $9 *$ \\
\hline
\end{tabular}

* Maior $n^{\circ}$ de opiniões 


\subsection{Informações dos alunos quanto às séries do ensino fundamental em que o o assunto alimentos vem sendo estudado}

$\mathrm{Na}$ rede regular de ensino público de zona urbana, tanto nas escolas que funcionam em período diurno quanto nas do noturno, o assunto é, segundo os alunos, mais trabalhado na $6^{\text {a }}$ série do ensino fundamental (Tabela 10).

Na rede regular de ensino particular, no ensino público de educação supletiva e na zona rural, os alunos apontam a $7^{\mathrm{a}}$ série (Tabela 10 ).

\subsection{Informações quanto as matérias cujos professores trabalham Educação}

\section{Alimentar}

O assunto vem sendo trabalhado com maior destaque pelos professores de Ciências tanto em escolas públicas quanto particulares, do período diurno e noturno, na rede regular e na educação supletiva, em zona urbana e rural, em todas as categorias de escolas; em seguida, foi bastante enfatizado o trabalho dos professores de Educação Física e Português em todas as escolas; apenas os alunos da educação supletiva, equipararam o trabalho dos professores de Educação Física ao dos professores de Matemática quanto a Educação Alimentar e Nutricional (Tabela 11). 
Tabela 10. Informações sobre as séries do ensino fundamental em que os assuntos ALIMENTOS e NUTRIÇÃO têm sido ministrados em sala de aula. Piracicaba (SP), 2004

\begin{tabular}{|c|c|c|c|c|c|c|c|c|c|c|c|c|c|c|c|}
\hline \multirow{2}{*}{$\begin{array}{l}\text { Séries do Ensino } \\
\text { Fundamental }\end{array}$} & \multicolumn{3}{|c|}{ EPU regular diurno } & \multicolumn{3}{|c|}{ EPU regular noturno } & \multicolumn{3}{|c|}{ EPU Educação supletiva } & \multicolumn{3}{|c|}{ EPU rural } & \multicolumn{3}{|c|}{ EPA } \\
\hline & $\begin{array}{c}\text { ouv } \\
\text { existente }\end{array}$ & $\begin{array}{l}\text { II } \\
\text { escolha }\end{array}$ & $\%$ & $\begin{array}{c}140 \\
\text { existente }\end{array}$ & $\begin{array}{c}\text { I" } \\
\text { escolha }\end{array}$ & $\%$ & $\begin{array}{c}1<0 \\
\text { existente }\end{array}$ & $\begin{array}{c}\text { "' } \\
\text { escolha }\end{array}$ & $\%$ & $\begin{array}{c}1<1 \\
\text { existente }\end{array}$ & $\begin{array}{c}\text { I" } \\
\text { escolha }\end{array}$ & $\%$ & $\begin{array}{c}\angle 1< \\
\text { existente }\end{array}$ & $\begin{array}{c}\text { I' } \\
\text { escolha }\end{array}$ & $\%$ \\
\hline $1^{a}$ Série & & 82 & 10,17 & & 16 & 11,19 & & 12 & 10 & & 20 & 15,75 & & 20 & 9,43 \\
\hline $2^{a}$ Série & & 64 & 7,94 & & 21 & 14,69 & & 11 & 9,17 & & 19 & 14,96 & & 28 & 13,21 \\
\hline $3^{\text {a }}$ Série & & 111 & 13,77 & & 17 & 11,89 & & 20 & 16,67 & & 41 & 32,28 & & 44 & 20,75 \\
\hline $4^{a}$ Série & & 231 & 28,66 & & 30 & 20,98 & & 25 & 20,83 & & 50 & 39,37 & & 47 & 22,17 \\
\hline 5a Série & & 233 & 28,91 & & 41 & 28,67 & & 21 & 17,50 & & 45 & 35,43 & & 32 & 15,09 \\
\hline $6^{\text {a }}$ Série & & 333 & $41,32 *$ & & 42 & $29,37 *$ & & 24 & 20 & & 32 & 25,20 & & 82 & 38,68 \\
\hline $7^{\text {a Série }}$ & & 305 & 37,84 & & 38 & 26,57 & & 32 & $26,67^{*}$ & & 58 & $45,67 *$ & & 113 & $53,30 *$ \\
\hline 8a Série & & 190 & 23,57 & & 36 & 25,17 & & 26 & 21,67 & & 43 & 33,86 & & 33 & 15,57 \\
\hline
\end{tabular}

* Maior concentração de respostas 
Tabela 11. Informações quanto a professores que vêm trabalhando Educação Alimentar e Nutricional. Piracicaba (SP), 2004

\begin{tabular}{|c|c|c|c|c|c|c|c|c|c|c|c|c|c|c|c|}
\hline \multirow[b]{2}{*}{ Matérias } & \multicolumn{3}{|c|}{ EPU regular diurno } & \multicolumn{3}{|c|}{ EPU regular noturno } & \multicolumn{3}{|c|}{ EPU educação supletiva } & \multicolumn{3}{|c|}{ EPU rural } & \multicolumn{3}{|c|}{ EPA } \\
\hline & $\begin{array}{c}\text { ouo } \\
\text { existente }\end{array}$ & II & $\%$ & $\begin{array}{c}140 \\
\text { existente }\end{array}$ & $\begin{array}{c}\text { I' } \\
\text { escolha }\end{array}$ & $\%$ & $\begin{array}{c}1<v \\
\text { existente }\end{array}$ & $\begin{array}{l}\text { II } \\
\text { escolha }\end{array}$ & $\%$ & $\begin{array}{c}1<1 \\
\text { existente }\end{array}$ & "I & $\%$ & $\begin{array}{c}<1< \\
\text { existente }\end{array}$ & II & $\%$ \\
\hline Português & & 84 & $10,42 *$ & & 44 & $30,77^{*}$ & & 22 & $18,33 *$ & & 35 & $27,56^{*}$ & & 12 & $5,66^{*}$ \\
\hline Geografia & & 30 & 3,72 & & 11 & 7,69 & & 14 & 11,67 & & 6 & 4,72 & & 6 & 2,83 \\
\hline Matemática & & 45 & 5,58 & & 27 & 18,88 & & 17 & $14,17^{*}$ & & 12 & 9,45 & & 6 & 2,83 \\
\hline Inglês & & 30 & 3,72 & & 13 & 9,09 & & 14 & 11,67 & & 6 & 4,72 & & 3 & 1,42 \\
\hline Ciências & & 711 & $88,21 *$ & & 101 & $70,63 *$ & & 75 & $62,50 *$ & & 112 & $88,19 *$ & & 165 & $77,83 *$ \\
\hline Ed. Física & & 215 & $26,67 *$ & & 40 & $27,97 *$ & & 17 & $14,17^{*}$ & & 33 & $25,98 *$ & & 85 & $40,09 *$ \\
\hline História & & 25 & 3,10 & & 11 & 7,69 & & 12 & 10 & & 7 & 5,51 & & 7 & 3,30 \\
\hline Nenhum & & 43 & 5,33 & & 15 & 10,49 & & 14 & 11,67 & & 5 & 3,94 & & 3 & 1,42 \\
\hline
\end{tabular}

* Matérias mais indicadas 


\subsection{Expressão percentual de conhecimento dos alunos quanto ao que seja um cardápio adequado a uma refeição}

Os maiores percentuais de alunos que demonstram ter noção do que seja um cardápio adequado a uma refeição, estão entre os da rede regular de ensino diurno, tanto de escolas públicas $(77,67 \%)$ quanto de escolas particulares (75,94\%). Tanto em uma quanto em outra, a população feminina demonstra estar mais inteirada:

- em escolas públicas - população masculina 74,81\% e feminina 80,29\%

-em escolas particulares - população masculina 75,00\% e feminina $77,17 \%$

Na zona rural ocorre o contrário: $71,43 \%$ da população masculina demonstra conhecer o assunto contra 65,63\% da população feminina (Tabela 12).

Os alunos do período noturno, seja da rede regular ou da educação supletiva são os que menos têm noção do assunto; entretanto mais de 50\% desses alunos demonstram ter algum conhecimento a respeito (Tabela 12).

Muitos alunos deixaram de responder à questão formulada sobre o cardápio, muito provavelmente por se sentirem inseguros ou mesmo por desconhecerem o assunto. Percentuais de respostas em branco:
Escolas Públicas - regular diurno regular noturno educação supletiva regular rural

Escolas Particulares - regular diurno

$$
\begin{array}{r}
\text { 3,38\% masculino e } \quad 3,80 \% \text { feminino } \\
\text { 14,08\% masculino e } 5,56 \% \text { feminino } \\
\text { 3,70\% masculino e } 10,61 \% \text { feminino } \\
11,11 \% \text { masculino e } 17,19 \% \text { feminino }
\end{array}
$$
$3,33 \%$ masculino e $3,26 \%$ feminino

Os maiores índices de omissão estão entre a população masculina e feminina de zona rural, população masculina da rede regular de ensino noturno e população feminina da educação supletiva ( Tabela 12). 
Tabela 12. Números e percentuais de alunos que demonstram um conhecimento relativo, sobre o que seja um cardápio adequado. Piracicaba (SP), 2004

\begin{tabular}{|c|c|c|c|c|c|c|c|c|c|c|c|c|c|c|c|c|c|c|c|c|c|}
\hline & \multicolumn{3}{|c|}{ Alunos existentes } & \multicolumn{6}{|c|}{ Têm noção } & \multicolumn{6}{|c|}{ Não têm noção } & \multicolumn{6}{|c|}{ Em branco } \\
\hline & masc & fem & total & masc & $\%$ & fem & $\%$ & total & $\%$ & masc & $\%$ & fem & $\%$ & total & $\%$ & masc & $\%$ & fem & $\%$ & total & $\%$ \\
\hline $\begin{array}{l}\text { EPU reg. noturno } \\
(\mathrm{A}+\mathrm{B}+\mathrm{C})\end{array}$ & 71 & 72 & 143 & 37 & 52,11 & 44 & 61,11 & 81 & 56,64 & 24 & $33,80^{*}$ & 24 & $33,33^{*}$ & 48 & $33,57 *$ & 10 & $14,08^{*}$ & 4 & 5,56 & 14 & $9,79^{*}$ \\
\hline $\begin{array}{l}\text { Eru ity. eu. } \\
\text { supletiva } \\
(\Lambda \perp \mathrm{D} \perp \Gamma)\end{array}$ & 54 & 66 & 120 & 32 & 59,26 & 44 & 66,67 & 76 & 63,33 & 20 & $37,04 *$ & 15 & $22,73^{*}$ & 35 & $29,17^{*}$ & 2 & 3,70 & 7 & $10,61^{*}$ & 9 & 7,50 \\
\hline EPU rural & 63 & 64 & 127 & 45 & 71,43 & 42 & 65,63 & 87 & 68,50 & 11 & 17,46 & 11 & 17,19 & 22 & 17,32 & 7 & $11,11^{*}$ & 11 & $17,19 *$ & 18 & $14,17^{*}$ \\
\hline
\end{tabular}

* Maiores percentuais 


\subsection{Percepções dos alunos em relação à sua massa corporal, sem qualquer menção Ao Índice de Massa Corporal ( I.M.C)}

Antes de se calcular o I.M.C. solicitou-se que os alunos emitissem suas opiniões quanto à sua massa corporal (Tabela 13).

Após análise dos questionários, o I.M.C de cada aluno foi calculado, sendo que os seus pesos e alturas foram auto-referidos (Tabela 14 e Figura 12).

Considerou-se, a partir dos dados da Organização Mundial de Saúde (O.M.S.), sub-peso o I.M.C abaixo de 18,5; a faixa de normalidade entre 18,5 e 24,9; sobre-peso entre 25 e 29,9; obesidade grau I entre 30 e 34,9; obesidade grau II entre 35 e 39,9 e obesidade grau III acima de 40.

Mais de 50\% dos alunos da rede regular de ensino público diurno, de zona urbana ou rural, estão dentro da faixa de normalidade, assim como mais de $60 \%$ dos alunos da educação supletiva e da rede regular de ensino particular (Figura 12). É maior o percentual de alunos do sexo masculino nesta faixa: 59,88\%; o percentual da população feminina é de 54,83\% (Figura 13).

O sub-peso é mais presente entre alunos da zona rural (39,37\%), seguidos pelos da rede regular de ensino público noturno (30,07\%) e pelos do ensino regular diurno (29,03\%) (Figura 12). É mais presente na população feminina $(29,65 \%)$ do que na masculina (22,80\%) (Figura 13).

O sobre-peso atinge um máximo de 15\% entre alunos adultos da rede pública de educação supletiva; entre esses mesmos alunos registra-se o máximo de obesidade grau I (5,00\%) e obesidade grau II (0,83\%); quanto a obesidade grau III registra-se 2,10\% entre alunos da rede regular de ensino noturno, grande parte já engajada no mercado de trabalho e oriundos de camadas sócio-culturais menos privilegiadas (Figura 12). O sobre-peso é mais presente na população masculina (7,94\%) contra 3,50\% na feminina; ocorre o mesmo, em menores proporções, com relação à obesidade (Figura 13).

Observa-se no total geral, abrangendo todas as categorias de escolas, que entre os que se encontram na faixa de normalidade $30,36 \%$ pensam que precisam emagrecer e $6,69 \%$ que precisam engordar e 55,39\% se dizem satisfeitos com sua massa corporal (Tabela 16). 
Entre os alunos com sub-peso está o maior índice de satisfação $(59,19 \%)$; 29,19\% têm consciência que precisam engordar e 6,49 \% pensam que devem emagrecer ainda mais. ( Figura 15 e Tabela 17).

Considerando-se os alunos com sobre-peso e obesos, 76,47\% demonstram estar conscientes que precisam emagrecer; $22,55 \%$ se dizem satisfeitos com sua massa corporal e 0,98\% pensa que ainda precisa engordar (Figura 16 e Tabela 18).

Os alunos do sexo masculino de escolas rurais (69,84\%), de escolas regulares do período noturno $(64,79 \%)$ e as alunas de escolas particulares (56,52\%) são os que demonstram estar mais satisfeitos com sua massa corporal, sem terem informações quanto ao I.M.C. calculado (Tabela 13).

O maior índice de insatisfação está entre as alunas da educação supletiva (56,06\%), seguidas pelas alunas da rede regular de ensino diurno (39,43\%), oriundas das camadas sociais mais empobrecidas (Tabela 13).

Nota-se ainda que, de maneira geral, os alunos do sexo masculino estão mais satisfeitos com sua massa corporal que as alunas; eles têm o percentual de satisfação em $61,62 \%$ e elas em $47,41 \%$ no cômputo geral ( Tabela 13 ).

\subsection{O I.M.C. calculado e comparado às percepções dos alunos.}

A Tabela 19 mostra o Índice de Massa Corporal calculado com a pretensão de ganho ou perda de peso. Constatou-se, ao calcular o Índice de Massa Corporal de todos os que sabiam informar seu peso e altura que:

$22,80 \%$ dos alunos e $29,65 \%$ das alunas estão com sub-peso;

59,88\% dos alunos e 54,83\% das alunas têm o I.M.C dentro da normalidade;

7,94\% dos alunos e 3,50\% das alunas estão com sobre-peso;

$1,15 \%$ dos alunos e $1,12 \%$ das alunas estão com obesidade grau I;

0,14\% dos alunos e $0,14 \%$ das alunas estão com obesidade grau II;

0,29\% dos alunos e $0,28 \%$ das alunas estão com obesidade grau III

Observa-se que a maioria dos alunos se encontra com I.M.C. entro da faixa de normalidade. 
Dos 1414 alunos participantes dessa pesquisa, 1279 ( 639 masculinos e 640 femininos) são os que souberam informar seu peso e altura para que o I.M.C. fosse calculado.

Entre os 807 que estão dentro da faixa de normalidade, 65,54\% dos alunos do sexo masculino e $44,64 \%$ do sexo feminino encontram-se satisfeitos consigo mesmos; $10,60 \%$ dos estudantes do sexo masculino e $2,55 \%$ do feminino pensam que precisam engordar e $18,31 \%$ dos alunos do sexo masculino e $43,00 \%$ do feminino acreditam que precisam emagrecer.

Os alunos na faixa de sub-peso são 370 . Entre eles, 65,00\% dos alunos do sexo masculino e 55,19\% do sexo feminino estão satisfeitos com sua massa corporal; 31,00\% dos alunos do sexo masculino e 27,83\% do feminino têm ciência que devem engordar e $3,00 \%$ dos alunos do sexo masculino e $9,00 \%$ do feminino pensam que precisam emagrecer.

Quanto aos 102 alunos com I.M.C. acima da faixa de normalidade , 24,00\% dos alunos do sexo masculino e 5,56\% do feminino estão satisfeitos com sua massa corporal; $2,00 \%$ dos alunos do sexo masculino consideram que ainda precisam engordar; $70 \%$ dos alunos do sexo masculino e 94,44\% do feminino têm consciência que necessitam emagrecer.

Alguns cálculos não puderam ser feitos porque 2,16\% de alunos do sexo masculino e 3,64\% do sexo feminino não souberam informar seu peso; 4,18\% do sexo masculino e $5,17 \%$ do sexo feminino não souberam informar sua altura e $1,30 \%$ do sexo masculino e $1,68 \%$ do sexo feminino não souberam informar nem peso e nem altura ( Tabela 15).

Vê-se que são maiores os percentuais de população feminina que não soube informar esses dados (Tabela 15). 
Tabela 13. Opiniões dos alunos quanto a sua massa corporal, sem qualquer cálculo ou referência ao Índice de Massa Corpora -I.M.C. Piracicaba (SP), 2004

\begin{tabular}{|c|c|c|c|c|c|c|c|c|c|c|c|c|c|c|c|c|c|c|}
\hline \multirow{2}{*}{ Modalidade de Curso } & \multicolumn{2}{|c|}{$\begin{array}{l}\text { IV allumos } \\
\text { nvictantase }\end{array}$} & \multicolumn{4}{|c|}{ Precisa engordar } & \multicolumn{4}{|c|}{ Precisa emagrecer } & \multicolumn{4}{|c|}{ Está bom } & \multicolumn{4}{|c|}{ Em branco } \\
\hline & masc & fem & masc & $\%$ & fem & $\%$ & masc & $\%$ & fem & $\%$ & masc & $\%$ & fem & $\%$ & masc & $\%$ & fem & $\%$ \\
\hline EPU regular diurno A & 133 & 165 & 23 & 17,3 & 15 & 9,09 & 29 & 21,80 & 75 & 45,45 & 81 & 60,90 & 70 & 42,42 & 0 & 0,00 & 5 & 3,03 \\
\hline EPU regular diurno B & 153 & 146 & 17 & 11,1 & 17 & 11,64 & 30 & 19,61 & 53 & 36,30 & 101 & 66,01 & 76 & 52,05 & 5 & 3,27 & 1 & 0,68 \\
\hline EPU regular diurno $C$ & 99 & 110 & 16 & 16,2 & 15 & 13,64 & 11 & 11,11 & 38 & 34,55 & 60 & 60,61 & 57 & 51,82 & 12 & 12,12 & 0 & 0,00 \\
\hline $\begin{array}{l}\text { Total EPU regular } \\
\text { diurno urbano }\end{array}$ & 385 & 421 & 56 & 14,5 & 47 & 11,16 & 70 & 18,18 & 166 & 39,43 & 242 & 62,86 & 203 & 48,22 & 17 & 4,42 & 6 & 1,43 \\
\hline EPU regular diurno rural & 63 & 64 & 4 & 6,35 & 11 & 17,19 & 10 & 15,87 & 17 & 26,56 & 44 & 69,84 & 29 & 45,31 & 5 & 7,94 & 7 & 10,94 \\
\hline EPU regular noturno A & 23 & 17 & 8 & 34,8 & 4 & 23,53 & 2 & 8,70 & 5 & 29,41 & 13 & 56,52 & 8 & 47,06 & 0 & 0,00 & 0 & 0,00 \\
\hline EPU regular noturno B & 30 & 40 & 4 & 13,3 & 10 & 25,00 & 4 & 13,33 & 10 & 25 & 19 & 63,33 & 18 & 45,00 & 3 & 10 & 2 & 5 \\
\hline EPU regular noturno $C$ & 18 & 15 & 3 & 16,7 & 2 & 13,33 & 1 & 5,56 & 7 & 46,67 & 14 & 77,78 & 6 & 40,00 & 0 & 0,00 & 0 & 0,00 \\
\hline $\begin{array}{l}\text { Total EPU regular } \\
\text { noturno }\end{array}$ & 71 & 72 & 15 & 21,1 & 16 & 22,22 & 7 & 9,86 & 22 & 30,56 & 46 & 64,79 & 32 & 44,44 & 3 & 4,23 & 2 & 2,78 \\
\hline EPU Ed. Supletiva A & 19 & 34 & 5 & 26,3 & 3 & 8,82 & 3 & 15,79 & 21 & 61,76 & 11 & 57,89 & 10 & 29,41 & 0 & 0,00 & 0 & 0,00 \\
\hline EPU Ed. Supletiva B & 18 & 21 & 5 & 27,8 & 2 & 9,52 & 5 & 27,78 & 11 & 52,38 & 8 & 44,44 & 8 & 38,10 & 0 & 0,00 & 0 & 0,00 \\
\hline EPU Ed. Supletiva C & 17 & 11 & 3 & 17,6 & 1 & 9,09 & 2 & 11,76 & 5 & 45,45 & 11 & 64,71 & 5 & 45,45 & 1 & 5,88 & 0 & 0,00 \\
\hline Total EPU Ed. Supletiva & 54 & 66 & 13 & 24,1 & 6 & 9,09 & 10 & 18,52 & 37 & 56,06 & 30 & 55,56 & 23 & 34,85 & 1 & 1,85 & 0 & 0,00 \\
\hline EPA $\alpha$ & 60 & 47 & 9 & 15 & 2 & 4,26 & 17 & 28,33 & 15 & 31,91 & 34 & 56,67 & 30 & 63,83 & 0 & 0,00 & 0 & 0,00 \\
\hline EPA $\beta$ & 35 & 22 & 4 & 11,4 & 2 & 9,09 & 9 & 25,71 & 8 & 36,36 & 22 & 62,86 & 12 & 54,55 & 0 & 0,00 & 0 & 0,00 \\
\hline EPA $\chi$ & 25 & 23 & 6 & 24 & 3 & 13,04 & 10 & 40,00 & 10 & 43,48 & 9 & 36,00 & 10 & 43,48 & 0 & 0,00 & 0 & 0,00 \\
\hline Total EPA & 120 & 92 & 19 & 15,8 & 7 & 7,61 & 36 & 30,00 & 33 & 35,87 & 65 & 54,17 & 52 & 56,52 & 0 & 0,00 & 0 & 0,00 \\
\hline TOTAL GERAL & 693 & 715 & 107 & 15,4 & 87 & 12,17 & 133 & 19,19 & 275 & 38,46 & 427 & 61,62 & 339 & 47,41 & 26 & 3,75 & 21 & 2,94 \\
\hline
\end{tabular}




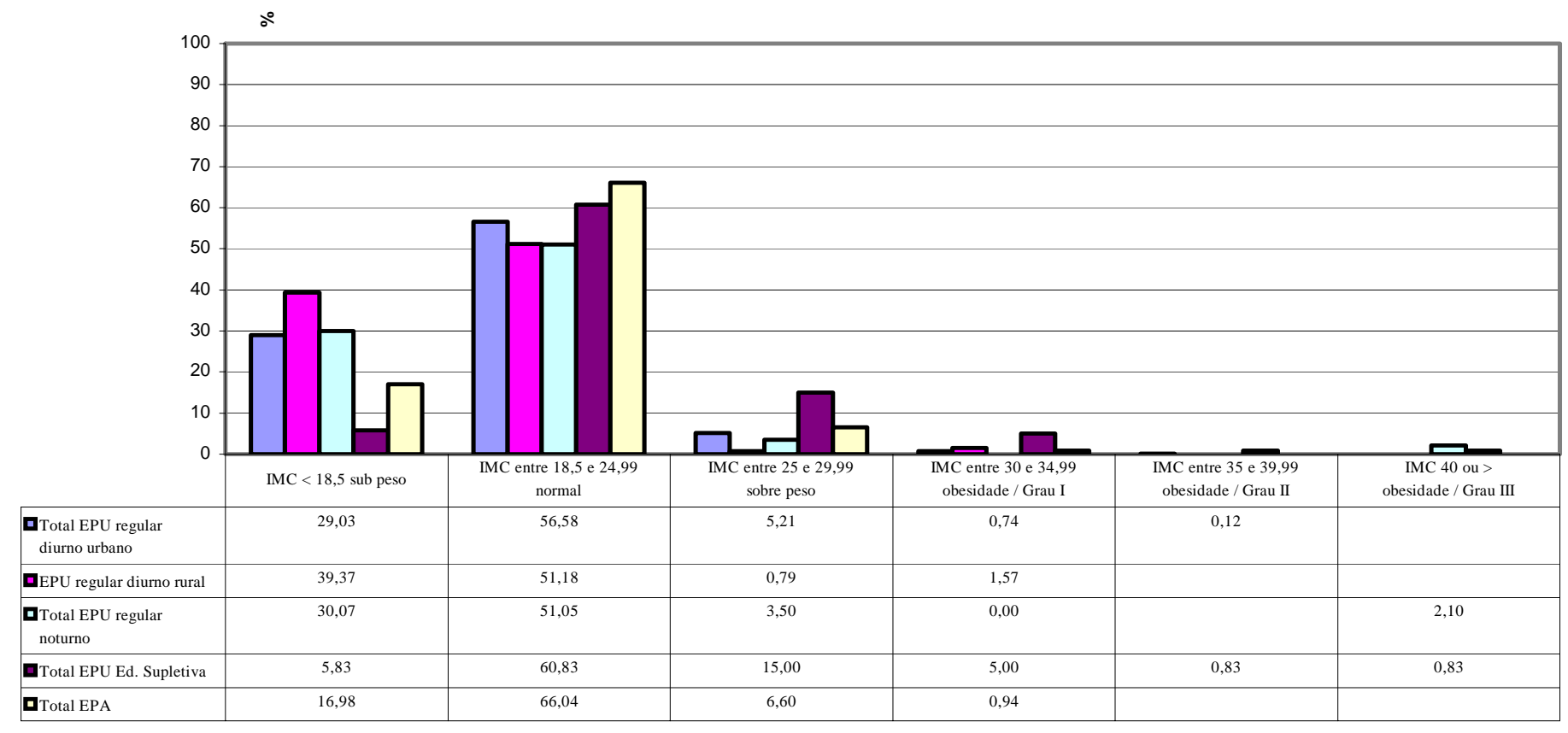

Figura 12 Índice de massa corporal calculado (peso e altura dos alunos auto - referidos Piracicaba (SP), 2004 


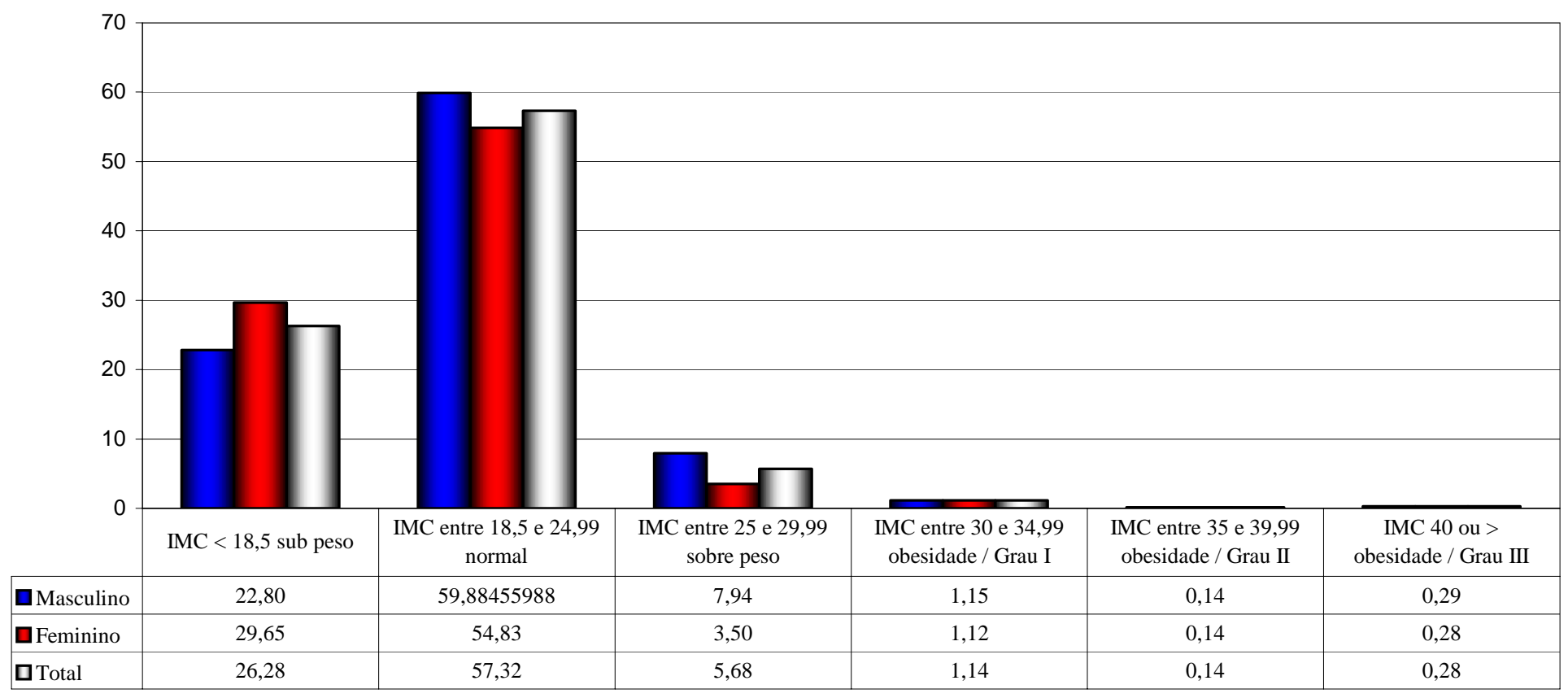

Figura 13 Comparativo de massa corporal entre gêneros - Piracicaba (SP), 2004 


\section{Tabela 14. Indice de Massa Corporal (I.M.C.). calculado (peso e altura dos alunos auto-referidos). Piracicaba (SP), 2004}

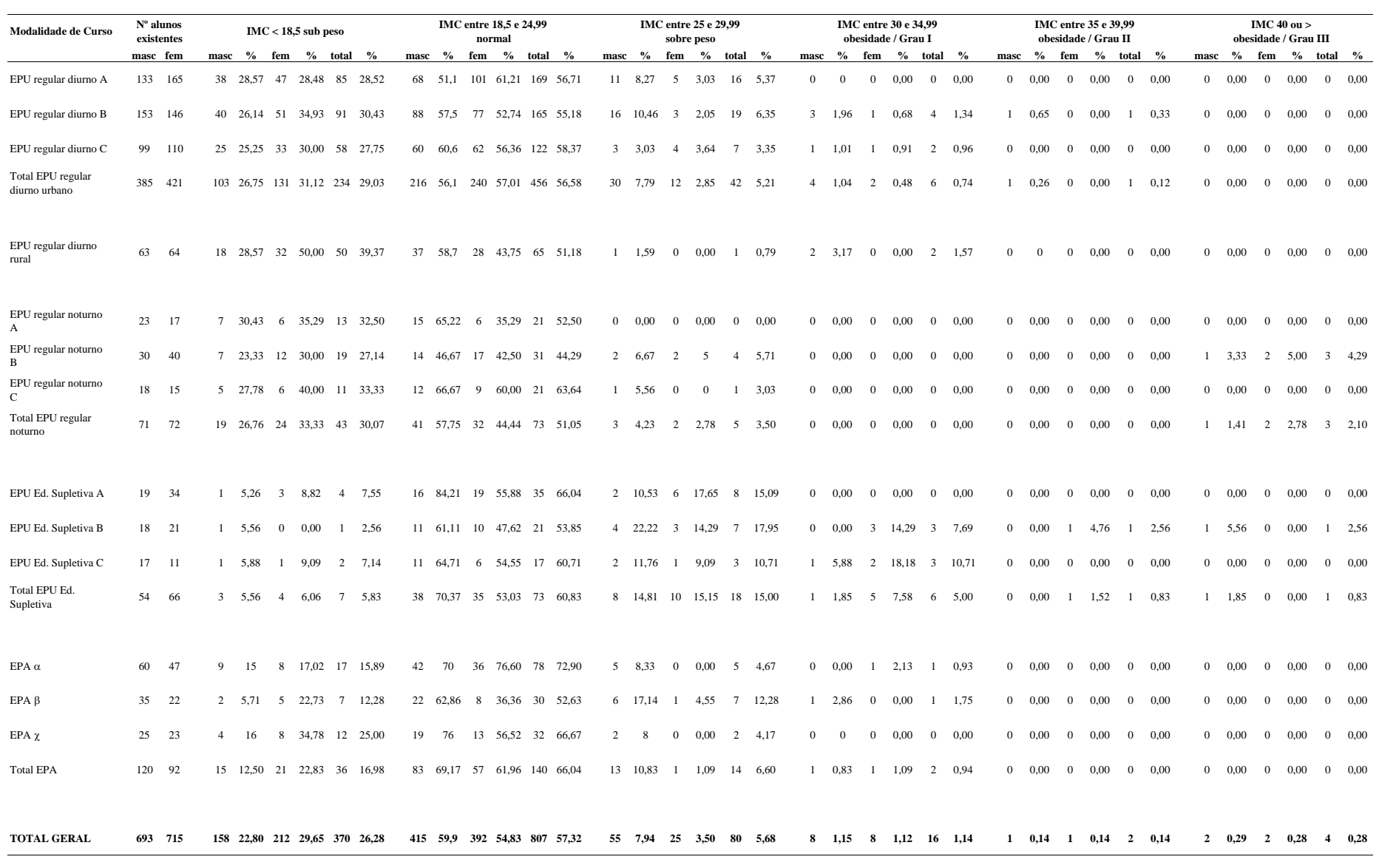

Na tabela 15 constam os percentuais de alunos que nãos souberam informar peso e/ou altura 
Tabela 15. Índice de Massa Corporal calculado (peso e altura dos alunos auto-referidos). Piracicaba (SP), 2004

\begin{tabular}{|c|c|c|c|c|c|c|c|c|c|c|c|c|c|c|}
\hline \multirow[t]{2}{*}{ Modalidade de Curso } & \multicolumn{2}{|c|}{$\begin{array}{l}\mathbf{N}^{0} \text { alunos } \\
\text { existentes }\end{array}$} & \multicolumn{4}{|c|}{ Não sabem o peso } & \multicolumn{4}{|c|}{ Não sabem a altura } & \multicolumn{4}{|c|}{$\begin{array}{c}\text { Não sabem o peso nem } \\
\text { a altura }\end{array}$} \\
\hline & masc & fem & masc & $\%$ & fem & $\%$ & masc & $\%$ & fem & $\%$ & masc & $\%$ & fem & $\%$ \\
\hline EPU regular diurno $\mathrm{A}$ & 133 & 165 & 8 & 6,02 & 4 & 2,42 & 6 & 4,51 & 3 & 1,82 & 2 & 1,50 & 5 & 3,03 \\
\hline EPU regular diurno $B$ & 153 & 146 & 0 & 0,00 & 5 & 3,42 & 5 & 3,27 & 9 & 6,16 & 0 & 0,00 & 0 & 0,00 \\
\hline EPU regular diurno $\mathrm{C}$ & 99 & 110 & 2 & 2,02 & 4 & 3,64 & 4 & 4,04 & 5 & 4,55 & 4 & 4,04 & 1 & 0,91 \\
\hline $\begin{array}{l}\text { Total EPU regular } \\
\text { diurno urbano }\end{array}$ & 385 & 421 & 10 & 2,60 & 13 & 3,09 & 15 & 3,90 & 17 & 4,04 & 6 & 1,56 & 6 & 1,43 \\
\hline EPU regular diurno rural & 63 & 64 & 1 & 1,59 & 0 & 0,00 & 3 & 4,76 & 4 & 6,25 & 1 & 1,59 & 0 & 0,00 \\
\hline EPU regular noturno A & 23 & 17 & 1 & 4,35 & 4 & 23,53 & 0 & 0,00 & 0 & 0,00 & 0 & 0,00 & 1 & 5,88 \\
\hline EPU regular noturno B & 30 & 40 & 0 & 0,00 & 0 & 0,00 & 4 & 13,33 & 7 & 17,50 & 2 & 6,67 & 0 & 0,00 \\
\hline EPU regular noturno $C$ & 18 & 15 & 0 & 0,00 & 0 & 0,00 & 0 & 0,00 & 0 & 0,00 & 0 & 0,00 & 0 & 0,00 \\
\hline $\begin{array}{l}\text { Total EPU regular } \\
\text { noturno }\end{array}$ & 71 & 72 & 1 & 1,41 & 4 & 5,56 & 4 & 5,63 & 7 & 9,72 & 2 & 2,82 & 1 & 1,39 \\
\hline EPU Ed. Supletiva A & 19 & 34 & 0 & 0,00 & 0 & 0,00 & 0 & 0,00 & 4 & 11,76 & 0 & 0,00 & 2 & 5,88 \\
\hline EPU Ed. Supletiva B & 18 & 21 & 0 & 0,00 & 0 & 0,00 & 1 & 5,56 & 4 & 19,05 & 0 & 0,00 & 0 & 0,00 \\
\hline EPU Ed. Supletiva C & 17 & 11 & 0 & 0,00 & 0 & 0,00 & 2 & 11,76 & 1 & 9,09 & 0 & 0,00 & 0 & 0,00 \\
\hline Total EPU Ed. Supletiva & 54 & 66 & 0 & 0,00 & 0 & 0,00 & 3 & 5,56 & 9 & 13,64 & 0 & 0,00 & 2 & 3,03 \\
\hline EPA $\alpha$ & 60 & 47 & 2 & 3,33 & 2 & 4,26 & 1 & 1,67 & 0 & 0,00 & 0 & 0,00 & 0 & 0,00 \\
\hline EРA $\beta$ & 35 & 22 & 1 & 2,86 & 5 & 22,73 & 3 & 8,57 & 0 & 0,00 & 0 & 0,00 & 3 & 13,64 \\
\hline $\operatorname{EPA} \chi$ & 25 & 23 & 0 & 0,00 & 2 & 8,70 & 0 & 0,00 & 0 & 0,00 & 0 & 0,00 & 0 & 0,00 \\
\hline Total EPA & 120 & 92 & 3 & 2,50 & 9 & 9,78 & 4 & 3,33 & 0 & 0,00 & 0 & 0,00 & 3 & 3,26 \\
\hline TOTAL GERAL & 693 & 715 & 15 & 2,16 & 26 & 3,64 & 29 & 4,18 & 37 & 5,17 & 9 & 1,30 & 12 & 1,68 \\
\hline
\end{tabular}




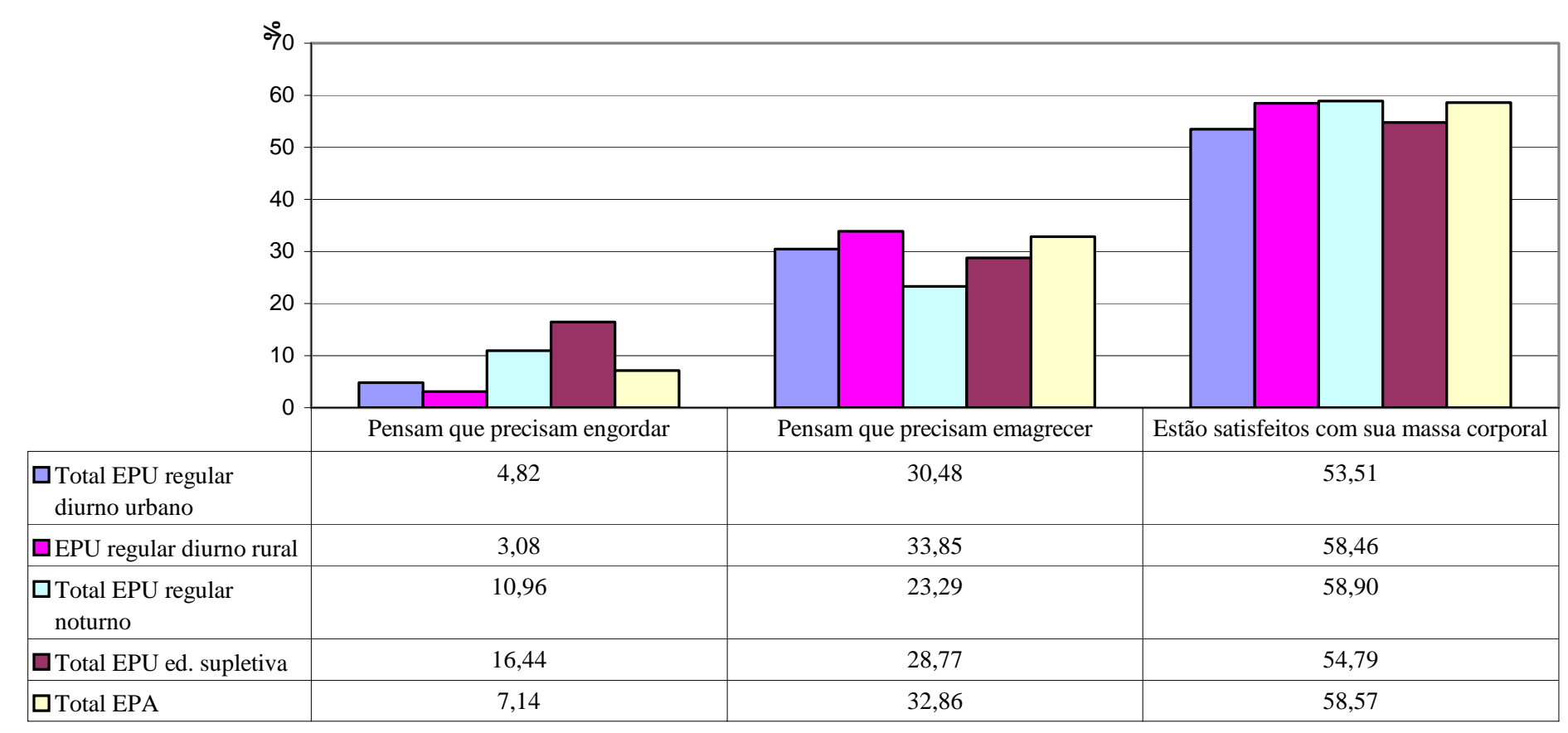

Figura 14 Como os alunos com IMC dentro da faixa de normalidade se auto-analisam. Piracicaba (SP), 2004 


\section{Tabela 16. Como os alunos com IMC dentro da faixa de normalidade se auto-analisam. Piracicaba (SP), 2004}

\begin{tabular}{|c|c|c|c|c|c|c|c|c|c|c|c|c|c|c|c|c|c|c|c|c|c|}
\hline \multirow[t]{2}{*}{ Modalidade de Curso } & \multicolumn{3}{|c|}{$\begin{array}{l}\begin{array}{c}\text { Node Alumos } \\
\text { IMC normal }\end{array} \\
\end{array}$} & \multicolumn{6}{|c|}{ Pensam que precisam engordar } & \multicolumn{6}{|c|}{ Pensam que precisam emagrecer } & \multicolumn{6}{|c|}{ Estão satisfetitos com sua massa corporal } \\
\hline & masc & $\begin{array}{c}\text { fem } \\
\text { fem }\end{array}$ & total & masc & $\%$ & fem & $\%$ & total & $\%$ & masc & $\%$ & fem & $\%$ & total & $\%$ & masc & $\%$ & fem & $\%$ & total & $\%$ \\
\hline EPU regular diurno A & 68 & 101 & 169 & 3 & 4,41 & 2 & 1,98 & 5 & 2,96 & 16 & 23,53 & 48 & 47,52 & 64 & 37,87 & 49 & 72,06 & 37 & 36,63 & 86 & 50,89 \\
\hline EPU regular diurno $B$ & 88 & 77 & 165 & 7 & 7,95 & 1 & 1,30 & 8 & 4,85 & 17 & 19,32 & 31 & 40,26 & 48 & 29,09 & 49 & 55,68 & 33 & 42,86 & 82 & 49,70 \\
\hline $\begin{array}{l}\text { EPU regular diurno C } \\
\text { Tev der }\end{array}$ & 60 & 62 & 122 & 6 & 10 & 3 & 4,84 & 9 & 7,38 & 5 & 8,33 & 22 & 35,48 & 27 & 22,13 & 45 & 75 & 31 & 50 & 76 & 62,30 \\
\hline $\begin{array}{l}\text { Total EPU regula } \\
\text { diurno urbano }\end{array}$ & 216 & 240 & 456 & 16 & 7,41 & 6 & 2,50 & 22 & 4,82 & 38 & 17,59 & 101 & 42,08 & 139 & 30,48 & 143 & 66,20 & 101 & 42,08 & 244 & 53,51 \\
\hline $\begin{array}{l}\text { EPU regular diurno } \\
\text { rural }\end{array}$ & 37 & 28 & 65 & 2 & 5,41 & 0 & 0,00 & 2 & 3,08 & 8 & 21,62 & 14 & 50 & 22 & 33,85 & 25 & 67,57 & 13 & 46,43 & 38 & 58,46 \\
\hline 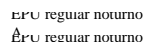 & 15 & 6 & & & & 0 & & & 19,05 & 2 & 13,33 & 2 & 33,33 & 4 & 19,05 & 9 & & & & 11 & 52,38 \\
\hline 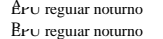 & 14 & 17 & 31 & 0 & 0,00 & 2 & 11,76 & 2 & 6,45 & 2 & 14,29 & 4 & 23,53 & 6 & 19,35 & 10 & 71,43 & 10 & 58,82 & 20 & 64,52 \\
\hline $\begin{array}{l}\text { Eru reguar nourno } \\
\text { Ty }\end{array}$ & 12 & 9 & 21 & 2 & 16,67 & 0 & 0,00 & 2 & 9,52 & 1 & 8,33 & 6 & 66,67 & 7 & 33,33 & 9 & 75 & 3 & 33,33 & 12 & 57,14 \\
\hline $\begin{array}{l}\text { Total EPU regula } \\
\text { noturno }\end{array}$ & 41 & 32 & 73 & 6 & 14,63 & 2 & 6,25 & 8 & 10,96 & 5 & 12,20 & 12 & 37,50 & 17 & 23,29 & 28 & 68,29 & 15 & 46,88 & 43 & 58,90 \\
\hline EPU ed. supletiva A & 16 & 19 & 35 & 5 & 31,25 & 1 & 5,26 & 6 & 17,14 & 0 & 0,00 & 10 & 52,63 & 10 & 28,57 & 11 & 68,75 & 8 & 42,11 & 19 & 54,29 \\
\hline EPU ed. supletiva $B$ & 11 & 10 & 21 & 3 & 27,27 & 1 & 10 & 4 & 19,05 & 4 & 36,36 & 5 & $\begin{array}{l}5,00 \\
50\end{array}$ & 9 & 42,86 & 4 & 36,36 & 4 & 40 & 8 & 38,10 \\
\hline EPU ed. supletiva C & 11 & 6 & 17 & 2 & 18,18 & 0 & 0,00 & 2 & 11,76 & 0 & 0,00 & 2 & 33,33 & 2 & 11,76 & 9 & 81,82 & 4 & 66,67 & 13 & 76,47 \\
\hline $\begin{array}{l}\text { Total EPU ed. } \\
\text { supletiva }\end{array}$ & 38 & 35 & 73 & 10 & 26,32 & 2 & 5,71 & 12 & 16,44 & 4 & 10,53 & 17 & 48,57 & 21 & 28,77 & 24 & 63,16 & 16 & 45,71 & 40 & 54,79 \\
\hline EPA $\alpha$ & 42 & 36 & 78 & 3 & 7,14 & 0 & 0,00 & 3 & 3,85 & 10 & 23,81 & 12 & 33,33 & 22 & 28,21 & 29 & 69,05 & 22 & 61,11 & 51 & 65,38 \\
\hline ЕРA $\beta$ & 22 & 8 & 30 & 4 & 18,18 & 0 & 0,00 & 4 & 13,33 & 3 & 13,64 & 4 & 50 & 7 & 23,33 & 15 & 68,18 & 4 & 50 & 19 & 63,33 \\
\hline $\mathrm{EPA} x$ & 19 & 13 & 32 & 3 & 15,79 & 0 & 0,00 & 3 & 9,38 & 8 & 42,11 & 9 & 69,23 & 17 & 53,13 & 8 & 42,11 & 4 & 30,77 & 12 & 37,50 \\
\hline Total EPA & 83 & 57 & 140 & 10 & 12,05 & 0 & 0,00 & 10 & 7,14 & 21 & 25,30 & 25 & 43,86 & 46 & 32,86 & 52 & 62,65 & 30 & 52,63 & 82 & 58,57 \\
\hline
\end{tabular}

OBS: Foram desconsideradas respostas dubiais e em branco. 


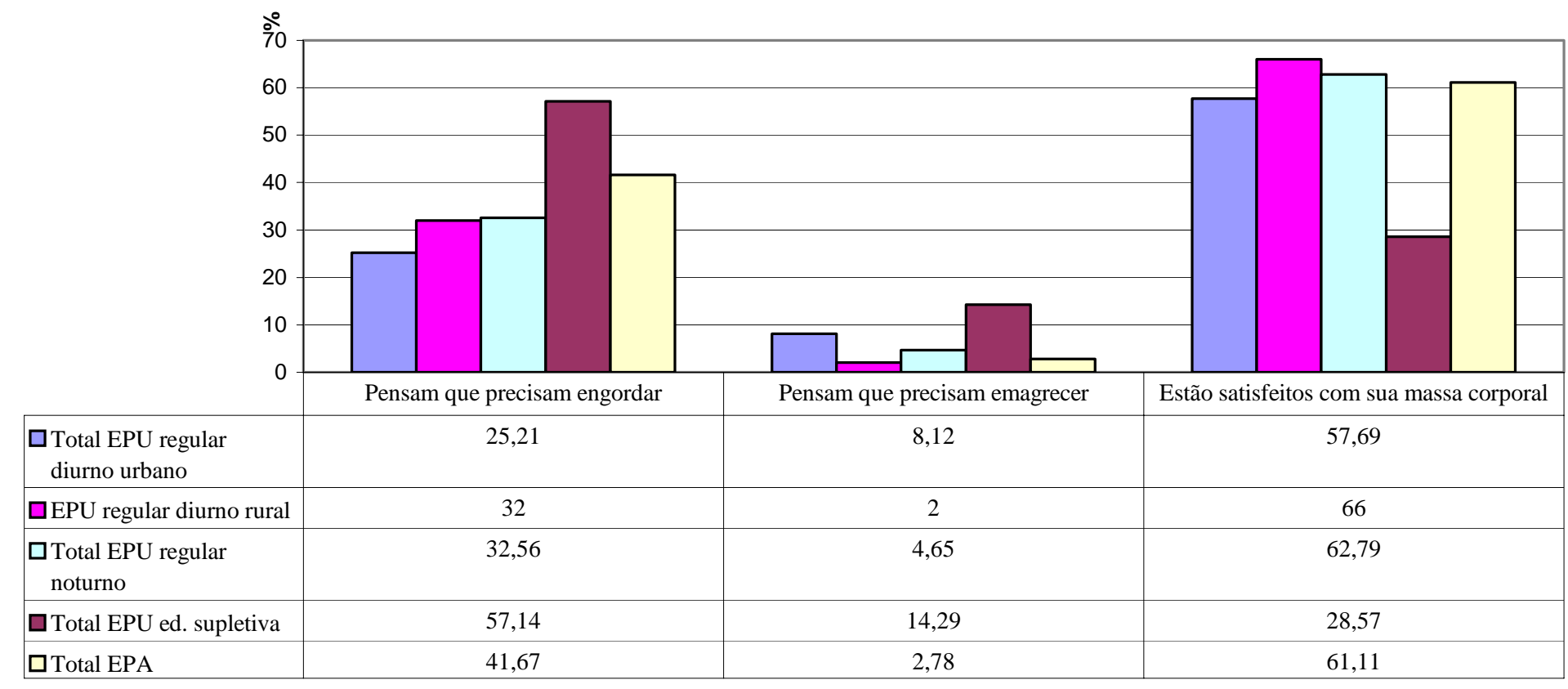

Figura 15 Como os alunos com IMC abaixo da faixa de normalidade (com sub-peso) se auto analisam Piracicaba

(SP), 2004 
Tabela 17. Como os alunos com IMC abaixo da faixa de normalidade (com sub-peso) se auto-analisam. Piracicaba (SP), 2004

\begin{tabular}{|c|c|c|c|c|c|c|c|c|c|c|c|c|c|c|c|c|c|c|c|c|c|}
\hline \multirow[t]{2}{*}{ Modalidade de Curso } & \multicolumn{3}{|c|}{$\begin{array}{c}\mathbf{N}^{\circ} \text { de Alunos com } \\
\text { sub-peso }\end{array}$} & \multicolumn{6}{|c|}{ Pensam que precisam engordar } & \multicolumn{6}{|c|}{ Pensam que precisam emagrecer } & \multicolumn{6}{|c|}{ Estão satisfeitos com sua massa corporal } \\
\hline & masc & fem & total & masc & $\%$ & fem & $\%$ & total & $\%$ & masc & $\%$ & fem & $\%$ & total & $\%$ & masc & $\%$ & fem & $\%$ & total & $\%$ \\
\hline EPU regular diurno A & 38 & 47 & 85 & 12 & 31,58 & 11 & 23,40 & 23 & 27,06 & 1 & 2,63 & 5 & 10,64 & 6 & 7,06 & 24 & 63,16 & 24 & 51,06 & 48 & 56,47 \\
\hline EPU regular diurno B & 40 & 51 & 91 & 8 & 20 & 9 & 17,65 & 17 & 18,68 & 1 & 2,50 & 5 & 9,80 & 6 & 6,59 & 29 & 72,50 & 26 & 50,98 & 55 & 60,44 \\
\hline EPU regular diurno $C$ & 25 & 33 & 58 & 7 & 28 & 12 & 36,36 & 19 & 32,76 & 0 & 0,00 & 7 & 21,21 & 7 & 12,07 & 17 & 68 & 15 & 45,45 & 32 & 55,17 \\
\hline $\begin{array}{l}\text { Total EPU regular } \\
\text { diurno urbano }\end{array}$ & 103 & 131 & 234 & 27 & 26,21 & 32 & 24,43 & 59 & 25,21 & 2 & 1,94 & 17 & 12,98 & 19 & 8,12 & 70 & 67,96 & 65 & 49,62 & 135 & 57,69 \\
\hline EPU regular noturno $\mathrm{A}$ & 7 & 6 & 13 & 3 & 42,86 & 1 & 16,67 & 4 & 30,77 & 0 & 0,00 & 0 & 0,00 & 0 & 0,00 & 4 & 57,14 & 6 & 100 & 10 & 76,92 \\
\hline EPU regular noturno B & 7 & 12 & 19 & 4 & 57,14 & 3 & 25 & 7 & 36,84 & 1 & 14,29 & 0 & 0,00 & 1 & 5,26 & 3 & 42,86 & 7 & 58,33 & 10 & 52,63 \\
\hline EPU regular noturno $C$ & 5 & 6 & 11 & 1 & 20 & 2 & 33,33 & 3 & 27,27 & 0 & 0,00 & 1 & 16,67 & 1 & 9,09 & 4 & 80 & 3 & 50 & 7 & 63,64 \\
\hline $\begin{array}{l}\text { Total EPU regular } \\
\text { noturno }\end{array}$ & 19 & 24 & 43 & 8 & 42,11 & 6 & 25 & 14 & 32,56 & 1 & 5,26 & 1 & 4,17 & 2 & 4,65 & 11 & 57,89 & 16 & 66,67 & 27 & 62,79 \\
\hline EPU ed. supletiva A & 1 & 3 & 4 & 0 & 0,00 & 1 & 33,33 & 1 & 25 & 1 & 100 & 0 & 0,00 & 1 & 25 & 0 & 0,00 & 2 & 66,67 & 2 & 50 \\
\hline EPA $\alpha$ & 9 & 8 & 17 & 6 & 66,67 & 2 & 25 & 8 & 47,06 & 0 & 0,00 & 1 & 12,50 & 1 & 5,88 & 3 & 33,33 & 7 & 87,50 & 10 & 58,82 \\
\hline EPA $\beta$ & 2 & 5 & 7 & 0 & 0,00 & 1 & 20 & 1 & 14,29 & 0 & 0,00 & 0 & 0,00 & 0 & 0,00 & 2 & 100 & 4 & 80 & 6 & 85,71 \\
\hline EPA $\chi$ & 4 & 8 & 12 & 3 & 75 & 3 & 37,50 & 6 & 50 & 0 & 0,00 & 0 & 0,00 & 0 & 0,00 & 1 & 25 & 5 & 62,50 & 6 & 50 \\
\hline Total EPA & 15 & 21 & 36 & 9 & 60 & 6 & 28,57 & 15 & 41,67 & 0 & 0,00 & 1 & 4,76 & 1 & 2,78 & 6 & 40 & 16 & 76,19 & 22 & 61,11 \\
\hline TOTAL GERAL & 158 & 212 & 370 & 49 & 31,01 & 59 & 27,83 & 108 & 29,19 & 4 & 2,53 & 20 & 9,43 & 24 & 6,49 & 102 & 64,56 & 117 & 55,19 & 219 & 59,19 \\
\hline
\end{tabular}

OBS: Foram desconsideradas respostas dúbias e em branco. 


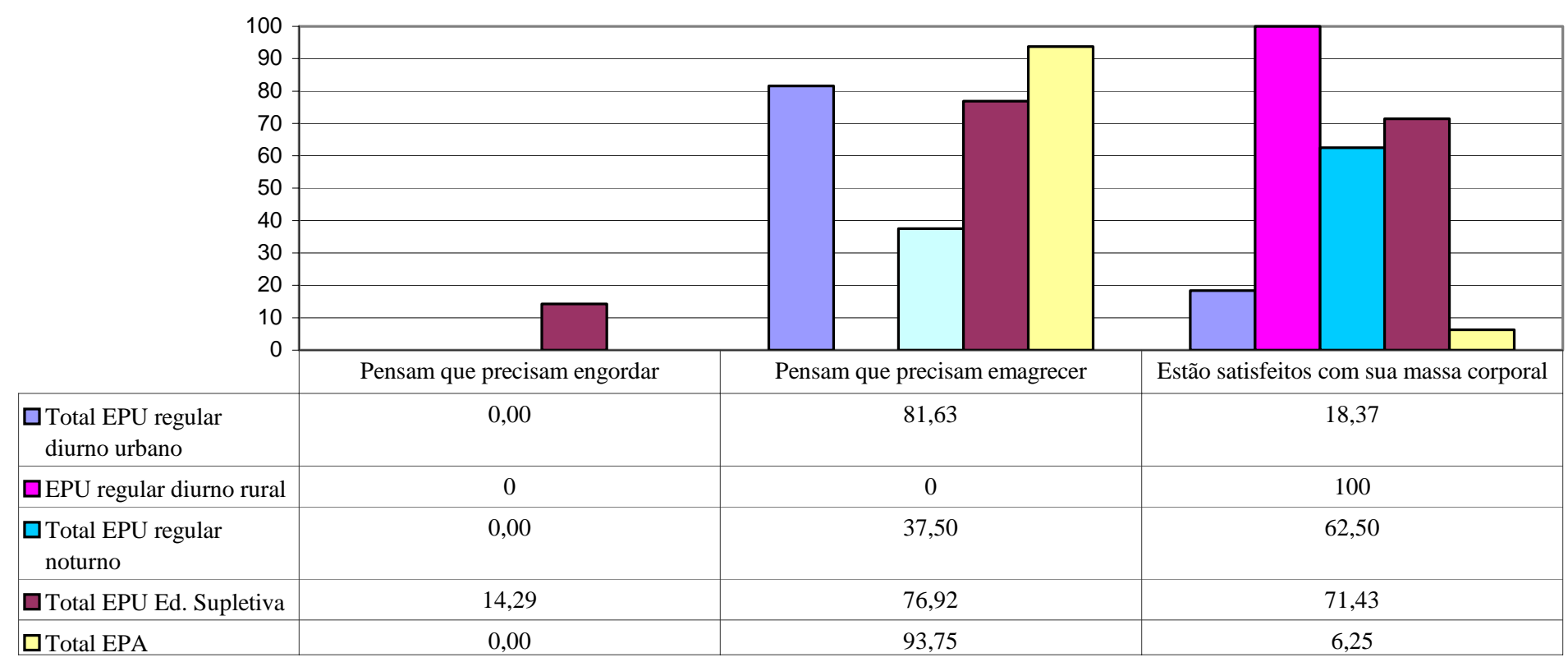

Figura 16 Como os alunos com IMC acima da faixa de normalidade (com sobre-peso e obesos) se auto- analisam.

Piracicaba (SP), 2004 
Tabela 18. Como os alunos com IMC acima da faixa de normalidade (com sobre-peso e obesos) se auto-analisam. Piracicaba (SP), 2004

\begin{tabular}{|c|c|c|c|c|c|c|c|c|c|c|c|c|c|c|c|c|c|c|}
\hline \multirow[t]{2}{*}{ Modalidade de Curso } & \multicolumn{3}{|c|}{$\begin{array}{c}\mathrm{N}^{0} \text { de Alunos acima } \\
\text { do peso }\end{array}$} & \multicolumn{5}{|c|}{ Pensam que precisam engordar } & \multicolumn{5}{|c|}{ Pensam que precisam emagrecer } & \multicolumn{5}{|c|}{$\begin{array}{l}\text { Estão satisfeitos com sua } \\
\text { massa corporal }\end{array}$} \\
\hline & masc & fem & total & $\%$ & fem & $\%$ & total & $\%$ & $\%$ & fem & $\%$ & total & $\%$ & $\%$ & fem & $\%$ & total & $\%$ \\
\hline EPU regular diurno $\mathrm{A}$ & 11 & 5 & 16 & 0,00 & 0 & 0,00 & 0 & 0,00 & 0,00 & 5 & 100 & 5 & 31,25 & 0,00 & 0 & 0,00 & 0 & 0,00 \\
\hline EPU regular diurno $\mathrm{C}$ & 4 & 5 & 9 & 0,00 & 0 & 0,00 & 0 & 0,00 & 0,00 & 5 & 100 & 5 & 55,56 & 0 & 0 & 0,00 & 0 & 0,00 \\
\hline $\begin{array}{l}\text { Total EPU regular } \\
\text { diurno urbano }\end{array}$ & 35 & 14 & 49 & 0,00 & 0 & 0,00 & 0 & 0,00 & 0,00 & 14 & 10,69 & 14 & 28,57 & 0 & 0 & 0,00 & 0 & 0,00 \\
\hline EPU regular noturno A & 0 & 0 & 0 & 0,00 & 0 & 0,00 & 0 & 0,00 & 0,00 & 0 & 0,00 & 0 & 0,00 & 0,00 & 0 & 0,00 & 0 & 0,00 \\
\hline EPU regular noturno B & 3 & 4 & 7 & 0,00 & 0 & 0,00 & 0 & 0,00 & 0,00 & 2 & 50 & 2 & 28,57 & 0,00 & 2 & 50,00 & 2 & 28,57 \\
\hline EPU regular noturno $\mathrm{C}$ & 1 & 0 & 1 & 0,00 & 0 & 0,00 & 0 & 0,00 & 0,00 & 0 & 0,00 & 0 & 0,00 & 0,00 & 0 & 0,00 & 0 & 0,00 \\
\hline $\begin{array}{l}\text { Total EPU regular } \\
\text { noturno }\end{array}$ & 4 & 4 & 8 & 0,00 & 0 & 0,00 & 0 & 0,00 & 0,00 & 2 & 50 & 2 & 25,00 & 0,00 & 2 & 50,00 & 2 & 25 \\
\hline $\begin{array}{l}\text { Total EPU Ed. } \\
\text { Supletiva }\end{array}$ & 10 & 16 & 26 & 0,00 & 0 & 0,00 & 0 & 0,00 & 0,00 & 14 & 87,50 & 14 & 53,85 & 0,00 & 2 & 50 & 2 & 28,57 \\
\hline EPA $\alpha$ & 5 & 1 & 6 & 0,00 & 0 & 0,00 & 0 & 0,00 & 0,00 & 1 & 12,50 & 1 & 17 & 0,00 & 0 & 0,00 & 0 & 0,00 \\
\hline ЕРА $\beta$ & 7 & 1 & 8 & 0,00 & 0 & 0,00 & 0 & 0,00 & 0,00 & 1 & 100 & 1 & 12,50 & 0,00 & 0 & 0,00 & 0 & 0,00 \\
\hline $\operatorname{EPA} \chi$ & 2 & 0 & 2 & 0,00 & 0 & 0,00 & 0 & 0,00 & 0,00 & 0 & 0,00 & 0 & 0 & 0,00 & 0 & 0,00 & 0 & 0,00 \\
\hline Total EPA & 14 & 2 & 16 & 0,00 & 0 & 0,00 & 0 & 0,00 & 0,00 & 2 & 100 & 2 & 12,50 & 0,00 & 0 & 0,00 & 0 & 0,00 \\
\hline TOTAL GERAL & 66 & 36 & 102 & 0,00 & $\mathbf{0}$ & 0,00 & $\mathbf{0}$ & 0,00 & 0,00 & 32 & 88,89 & 32 & 31,37 & 0,00 & 4 & 11,11 & 4 & 3,92 \\
\hline
\end{tabular}




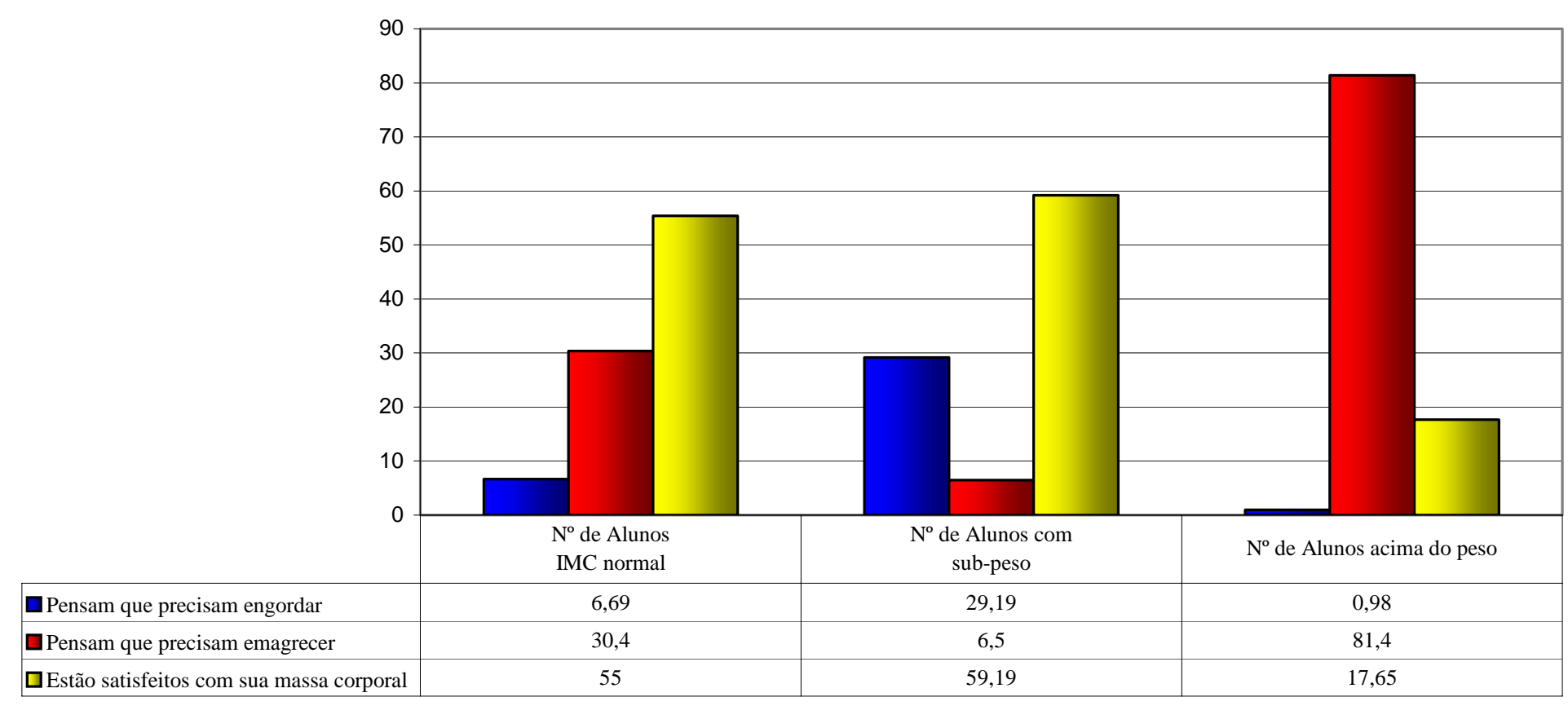

Figura 17 Comparativo entre IMC e pretensão de ganho ou perda de peso-Piracicaba (SP) 2004 
Tabela 19. Comparativa entre IMC e pretensão de ganho ou perda de peso. Piracicaba (SP), 2004

\begin{tabular}{|c|c|c|c|c|c|c|c|c|c|c|c|c|c|c|c|c|c|c|c|c|}
\hline & \multirow[b]{2}{*}{ masc } & \multirow[b]{2}{*}{ fem } & \multirow[b]{2}{*}{ total } & \multicolumn{5}{|c|}{ Pensam que precisam engordar } & \multicolumn{6}{|c|}{ Pensam que precisam emagrecer } & \multicolumn{6}{|c|}{ Estão satisfeitos com sua massa corporal } \\
\hline & & & & $\%$ & fem & $\%$ & total & $\%$ & masc & $\%$ & fem & $\%$ & total & $\%$ & masc & $\%$ & fem & $\%$ & total & $\%$ \\
\hline $\begin{array}{l}\mathrm{N}^{\circ} \text { de Alunos } \\
\text { IMC normal }\end{array}$ & 415 & 392 & 807 & 10,60 & 10 & 2,55 & 54 & 6,69 & 76 & 18,31 & 169 & 43 & 245 & 30,4 & 272 & 65,54 & 175 & 44,64 & 447 & 55 \\
\hline $\begin{array}{l}\mathrm{N}^{\circ} \text { de Alunos com } \\
\text { sub-peso }\end{array}$ & 158 & 212 & 370 & 31 & 59 & 27,83 & 108 & 29,19 & 4 & 3 & 20 & 9 & 24 & 6,5 & 102 & 65 & 117 & 55,19 & 219 & 59,19 \\
\hline $\begin{array}{l}N^{\circ} \text { de Alunos acima } \\
\text { do peso }\end{array}$ & 66 & 36 & 102 & 2 & 0 & 0,00 & 1 & 0,98 & 46 & 70 & 37 & 103 & 83 & 81,4 & 16 & 24 & 2 & 5,56 & 18 & 17,65 \\
\hline Total & 639 & 640 & 1279 & 0,00 & 69 & 10,78 & 163 & 12,74 & 126 & 19,72 & 226 & 35,31 & 352 & 27,52 & 390 & 61,03 & 294 & 45,94 & 684 & 53,48 \\
\hline
\end{tabular}




\subsection{SUGESTÕES DOS ALUNOS PARA PROMOÇÃO DA EDUCAÇÃO ALIMENTAR E NUTRICIONAL NA ESCOLA}

Confirmando nossa hipótese, os alunos sentem necessidade de mais orientações quanto a educação alimentar na escola.

Convidados a opinar, obteve-se sugestões de 79,86\% dos alunos:

$\begin{array}{lll}\text { EPU regular diurno urbano } & 77,40 \% \text { do sexo masculino } & 78,15 \% \text { do sexo feminino } \\ \text { EPU regular diurno rural } & 85,71 \% \text { do sexo masculino } & 85,94 \% \text { do sexo feminino } \\ \text { EPU regular noturno } & 63,38 \% \text { do sexo masculino } & 72,22 \% \text { do sexo feminino } \\ \text { EPU educação supletiva } & 66,67 \% \text { do sexo masculino } & 77,27 \% \text { do sexo feminino } \\ \text { EPA regular diurno } & 73,33 \% \text { do sexo masculino } & 91,30 \% \text { do sexo feminino }\end{array}$

Observa-se maior participação da população feminina quanto à emissão de sugestões (Tabela 20).

Período diurno:

Nas escolas públicas de zona urbana, tanto a população masculina quanto a feminina, apontam como maiores necessidades (Tabela 21) :

$1^{\circ}$ variar o cardápio da merenda escolar;

$2^{\circ}$ que os professores dêem mais orientações sobre educação alimentar;

$3^{\circ}$ que se venda produtos mais saudáveis nas cantinas escolares.

Nas escolas públicas de zona rural, tanto a população masculina quanto a feminina sugerem (Tabela 21):

$1^{\circ}$ variar o cardápio da merenda escolar;

$2^{\circ}$ propiciar palestras com nutricionistas;

$3^{0}$ que os professores dêem mais orientações sobre educação alimentar. 
Nas escolas particulares, tanto a população masculina quanto a feminina apontam como prioridades: (Tabela 21).

$1^{\circ}$ ter produtos mais saudáveis nas cantinas;

$2^{\circ}$ que os professores dêem mais orientações sobre educação alimentar;

$3^{\circ}$ oferecer palestras com nutricionistas; a população masculina pede ainda a distribuição de alimentação (merenda) gratuita.

Período noturno - apenas escolas públicas (Tabela 22).

$\mathrm{Na}$ rede regular de ensino, os alunos do sexo masculino e feminino indicam como prioridades:

$1^{0}$ oferecer merenda escolar e que os professores dêem mais orientações quanto a educação alimentar;

$2^{\circ}$ variar o cardápio da merenda ;

$3^{\circ}$ palestras com nutricionistas.

Considerando-se que algumas escolas oferecem merenda aos alunos do período noturno, parece-nos interessante que as demais também levem em consideração a realidade de sua clientela , tomando as medidas cabíveis para que possam ser atendidos em suas sugestões e necessidades.

Na rede de educação supletiva:

\footnotetext{
Sexo masculino

$1^{\circ}$ mais orientação pelos professores

$2^{\circ}$ oferecer merenda à noite

$3^{\circ}$ variar o cardápio da merenda
}

\author{
Sexo feminino \\ $1^{\circ}$ oferecer merenda à noite \\ $2^{\circ}$ mais orientação pelos professores \\ $3^{\circ}$ ter palestras com nutricionistas,ter \\ produtos mais saudáveis nas cantinas \\ e variar o cardápio da merenda.
}


Tabela 20. $\mathrm{N}^{\circ}$ alunos que apresentam sugestões para a escola poder ajudar mais os jovens quanto a Educação Alimentar e Nutricional. Piracicaba(SP), 2004

\begin{tabular}{|c|c|c|c|c|c|c|}
\hline \multirow[t]{2}{*}{ Modalidade de Curso } & \multicolumn{2}{|c|}{$\begin{array}{l}\mathbf{N}^{0} \text { alunos } \\
\text { existentes }\end{array}$} & \multicolumn{4}{|c|}{ Alunos que apresentaram sugestões } \\
\hline & masc & fem & masc & $\%$ & fem & $\%$ \\
\hline EPU regular diurno A & 133 & 165 & 71 & 53,38 & 83 & 50,30 \\
\hline EPU regular diurno B & 153 & 146 & 153 & 100 & 136 & 93,15 \\
\hline EPU regular diurno C & 99 & 110 & 74 & 74,75 & 110 & 100 \\
\hline $\begin{array}{l}\text { Total EPU regular } \\
\text { diurno urbano }\end{array}$ & 385 & 421 & 298 & 77,40 & 329 & 78,15 \\
\hline EPU regular diurno rural & 63 & 64 & 54 & 85,71 & 55 & 85,94 \\
\hline EPU regular noturno A & 23 & 17 & 20 & 86,96 & 9 & 52,94 \\
\hline EPU regular noturno B & 30 & 40 & 13 & 43,33 & 30 & 75 \\
\hline EPU regular noturno C & 18 & 15 & 12 & 66,67 & 13 & 86,67 \\
\hline $\begin{array}{l}\text { Total EPU regular } \\
\text { noturno }\end{array}$ & 71 & 72 & 45 & 63,38 & 52 & 72,22 \\
\hline EPU ed. supletiva A & 19 & 34 & 12 & 63,16 & 26 & 76,47 \\
\hline EPU ed. supletiva B & 18 & 21 & 14 & 77,78 & 17 & 80,95 \\
\hline EPU ed. supletiva C & 17 & 11 & 10 & 58,82 & 8 & 72,73 \\
\hline Total EPU ed. supletiva & 54 & 66 & 36 & 66,67 & 51 & 77,27 \\
\hline EPA $\alpha$ & 60 & 47 & 41 & 68,33 & 43 & 91,49 \\
\hline EPA $\beta$ & 35 & 22 & 24 & 68,57 & 21 & 95,45 \\
\hline EPA $\chi$ & 25 & 23 & 23 & 92 & 20 & 86,96 \\
\hline Total EPA & 120 & 92 & 88 & 73,33 & 84 & 91,30 \\
\hline TOTAL GERAL & 693 & 715 & 521 & 75,18 & 571 & 79,86 \\
\hline
\end{tabular}


Tabela 21. Sugestão dos alunos do período diurno para a escola melhor atendê-los quanto a Educação Alimentar. Piracicaba (SP), 2004

\begin{tabular}{|c|c|c|c|c|c|c|c|c|c|c|c|c|c|c|c|c|c|c|c|c|c|}
\hline & \multicolumn{8}{|c|}{ EPU Zona Urbana } & \multicolumn{8}{|c|}{ EPA Zona Urbana } & \multirow{2}{*}{\multicolumn{3}{|c|}{ EPU Zona Rural }} & \multicolumn{2}{|c|}{ Total Geral } \\
\hline & \multicolumn{2}{|c|}{ A } & \multicolumn{2}{|c|}{ B } & \multicolumn{2}{|c|}{ C } & \multicolumn{2}{|c|}{ Total } & \multicolumn{2}{|c|}{$\alpha$} & \multicolumn{2}{|c|}{$\beta$} & \multicolumn{2}{|c|}{$x$} & \multicolumn{2}{|c|}{ Total } & & & \multirow{2}{*}{ total } & \multirow{2}{*}{ masc } & \multirow{2}{*}{ fem } \\
\hline & masc & fem & masc & fem & masc & fem & masc & fem & masc & fem & masc & fem & masc & fem & masc & fem & mas & fem & & & \\
\hline variar o cardápio da merenda & 48 & 55 & 58 & 55 & 27 & 26 & 133 & 136 & 0 & 0 & 0 & 0 & 0 & 0 & 0 & 0 & 25 & 22 & 47 & 158 & 158 \\
\hline palestras com nutricionistas & 7 & 15 & 14 & 20 & 2 & 20 & 23 & 55 & 7 & 7 & 4 & 6 & 3 & 7 & 14 & 20 & 20 & 22 & 42 & 57 & 97 \\
\hline mais orientação pelos professores & 21 & 27 & 29 & 43 & 18 & 30 & 68 & 100 & 10 & 10 & 12 & 6 & 8 & 15 & 30 & 31 & 17 & 15 & 32 & 115 & 146 \\
\hline projeção de filmes educativos & 0 & 0 & 0 & 1 & 0 & 6 & 0 & 7 & 0 & 0 & 0 & 0 & 0 & 0 & 0 & 0 & 5 & 4 & 9 & 5 & 11 \\
\hline ter produtos mais saudáveis na cantina & 4 & 24 & 11 & 27 & 7 & 24 & 22 & 75 & 18 & 20 & 13 & 17 & 7 & 15 & 38 & 52 & 0 & 4 & 4 & 60 & 131 \\
\hline afixar cartazes e folhetos & 0 & 6 & 1 & 1 & 0 & 1 & 1 & 8 & 1 & 1 & 1 & 0 & 0 & 0 & 2 & 1 & 1 & 2 & 3 & 4 & 11 \\
\hline oferecer café da manhã na entrada & 1 & 2 & 5 & 0 & 3 & 9 & 9 & 11 & 1 & 0 & 0 & 0 & 0 & 0 & 1 & 0 & 1 & 1 & 2 & 11 & 12 \\
\hline ensinar evitar desperdício & 0 & 0 & 0 & 1 & 6 & 6 & 6 & 7 & 0 & 0 & 0 & 0 & 0 & 0 & 0 & 0 & 1 & 0 & 1 & 7 & 7 \\
\hline professores dar bons exemplos & 0 & 0 & 0 & 0 & 0 & 0 & 0 & 0 & 0 & 0 & 0 & 0 & 0 & 0 & 0 & 0 & 1 & 0 & 1 & 1 & \\
\hline fazer teatro & 0 & 0 & 0 & 0 & 0 & 0 & 0 & 0 & 0 & 0 & 0 & 0 & 0 & 0 & 0 & 0 & 0 & 1 & 1 & & 1 \\
\hline dar aulas práticas & 3 & 0 & 0 & 2 & 3 & 2 & 6 & 4 & 0 & 1 & 0 & 1 & 0 & 1 & 0 & 3 & 1 & 6 & 7 & 7 & 13 \\
\hline orientar os pais dos alunos & 0 & 1 & 0 & 0 & 0 & 8 & 0 & 9 & 2 & 0 & 1 & 0 & 1 & 0 & 4 & 0 & 0 & 1 & 1 & 4 & 10 \\
\hline desenvolver projetos & 0 & 2 & 1 & 0 & 0 & 9 & 1 & 11 & 0 & 0 & 0 & 0 & 0 & 1 & 0 & 1 & 0 & 0 & 0 & 1 & 12 \\
\hline promover debates & 0 & 0 & 0 & 0 & 0 & 1 & 0 & 1 & 1 & 0 & 0 & 0 & 0 & 0 & 1 & 0 & 0 & 0 & 0 & 1 & 1 \\
\hline distribuir merenda gratuita & 0 & 0 & 0 & 0 & 0 & 0 & 0 & 0 & 6 & 1 & 1 & 3 & 7 & 1 & 14 & 5 & 0 & 0 & 0 & 14 & 5 \\
\hline abaixar os preços da cantina & 0 & 4 & 3 & 0 & 0 & 2 & 3 & 6 & 3 & 1 & 3 & 0 & 3 & 0 & 9 & 1 & 0 & 0 & 0 & 12 & 7 \\
\hline totais de opiniões & 84 & 136 & 122 & 150 & 66 & 144 & 272 & 430 & 49 & 41 & 35 & 33 & 29 & 40 & 113 & 114 & 72 & 78 & 150 & 457 & 622 \\
\hline
\end{tabular}


Tabela 22. Sugestões dos alunos de escolas públicas do período noturno para a escola melhor atendê-los quanto a Educação Alimentar e Nutricional. Piracicaba (SP), 2004

\begin{tabular}{|c|c|c|c|c|c|c|c|c|c|c|c|c|c|c|c|c|c|c|}
\hline & \multicolumn{8}{|c|}{ Rede regular de ensino } & \multicolumn{8}{|c|}{ Rede de educação supletiva } & \multicolumn{2}{|c|}{ Total Geral } \\
\hline & \multicolumn{2}{|c|}{ A } & \multicolumn{2}{|c|}{ B } & \multicolumn{2}{|c|}{ C } & \multicolumn{2}{|c|}{ Total } & \multicolumn{2}{|c|}{ A } & \multicolumn{2}{|c|}{ B } & \multicolumn{2}{|c|}{ C } & \multicolumn{2}{|c|}{ Total } & \multirow{2}{*}{ masc } & \multirow{2}{*}{ fem } \\
\hline & masc & fem & masc & fem & masc & fem & masc & fem & masc & fem & masc & fem & masc & fem & masc & fem & & \\
\hline palestras com nutricionistas & 2 & 0 & 2 & 6 & 1 & 0 & 5 & 6 & 0 & 3 & 2 & 1 & 1 & 0 & 3 & 4 & 8 & 10 \\
\hline mais orientação pelos professores & 10 & 6 & 3 & 15 & 0 & 1 & 13 & 22 & 6 & 6 & 5 & 7 & 1 & 1 & 12 & 14 & 25 & 36 \\
\hline ter produtos mais saudáveis na cantina & 0 & 0 & 0 & 4 & 0 & 0 & 0 & 4 & 0 & 0 & 2 & 3 & 0 & 1 & 2 & 4 & 2 & 8 \\
\hline afixar cartazes e folhetos & 1 & 0 & 0 & 0 & 0 & 0 & 1 & 0 & 0 & 0 & 0 & 0 & 0 & 0 & 0 & 0 & 1 & 0 \\
\hline oferecer merenda & 8 & 6 & 5 & 15 & 0 & 1 & 13 & 22 & 7 & 11 & 0 & 0 & 4 & 5 & 11 & 16 & 24 & 38 \\
\hline ensinar fazer horta & 0 & 0 & 1 & 0 & 0 & 0 & 1 & 0 & 0 & 0 & 0 & 0 & 1 & 0 & 1 & 0 & 2 & 0 \\
\hline dar aulas práticas & 0 & 0 & 0 & 2 & 0 & 0 & 0 & 2 & 0 & 3 & 0 & 0 & 0 & 0 & 0 & 3 & 2 & 3 \\
\hline orientar os pais dos alunos & 0 & 0 & 1 & 0 & 0 & 0 & 1 & 0 & 1 & 1 & 0 & 2 & 0 & 0 & 1 & 3 & 2 & 3 \\
\hline promover debates & 0 & 0 & 0 & 1 & 0 & 0 & 0 & 1 & 0 & 0 & 0 & 0 & 0 & 0 & 0 & 0 & 0 & 1 \\
\hline abaixar os preços da cantina & 0 & 0 & 0 & 4 & 0 & 0 & 0 & 4 & 0 & 0 & 1 & 0 & 0 & 0 & 1 & 0 & 1 & 4 \\
\hline variar o cardápio da merenda & 0 & 0 & 0 & 0 & 11 & 13 & 11 & 13 & 1 & 0 & 5 & 4 & 0 & 0 & 6 & 4 & 17 & 17 \\
\hline totais de opiniões & 21 & 12 & 12 & 47 & 12 & 15 & 45 & 74 & 15 & 24 & 15 & 17 & 7 & 7 & 37 & 48 & 84 & 120 \\
\hline
\end{tabular}

Algumas escolas têm merenda a noite! 


\subsubsection{Excertos das opiniões dos alunos quanto a Educação Alimentar e Nutricional na escola}

\section{Período diurno - alunos adolescentes da rede regular de ensino}

\section{EPU - categoria A}

Alunos

"não dar sopa nas refeições da escola”; "servir um cardápio que os alunos gostem”;

“a escola deve falar bem mais sobre alimentos”; "servir comida boa, falar mais sobre alimentação e para isso a escola vai ter que melhorar muito"; "nas horas da merenda, dar lanche natural”; "uma merenda mais adequada, às vezes com frutas, legumes e uma cantina com frutas, lanches e sucos naturais”; “...muitas crianças e jovens são obesos por não ter uma boa orientação alimentar”.

Alunas

“ter variedade no cardápio da merenda; no calor poderiam servir suco natural e não sopa ou polenta”; "mudar o cardápio de vez em quando”; “eu acho que deveriam melhorar a merenda, abaixar os preços das porcarias que vendem na cantina; por favor me escutem; na verdade já estava na hora do aluno ter o direito de falar o que sente nesta escola”; “à tarde poderiam servir frutas ou biscoitos salgados e não comida”; “a escola deve oferecer palestras com nutricionistas”; “a escola deveria ter professor para orientar sobre alimentação"; “eu estudava em uma escola em que tinha orientação sobre alimentos antes dos intervalos; eles colocavam na mesa apenas carne ou peixe, suco natural, arroz, feijão, frutas e verduras para os alunos se acostumarem; era escrito o tanto de comida que era para se por no prato, por exemplo: duas colheres de arroz, uma folha de alface, etc e olhe que a escola não era particular”.

\section{EPU - categoria B}

Alunos 
“melhorar a merenda escolar e dar o que beber na merenda”; “dar uma fruta junto com a merenda escolar"; "na minha opinião a escola deveria montar um cardápio balanceado com alimentos construtores, energéticos e reguladores e fazer com que os alunos aprendam isso para fazer em casa”; "na minha opinião a escola deveria convidar nutricionistas para dar palestras; ou os próprios nutricionistas deveriam querer ver os jovens saudáveis e pedir na escola, para deixarem fazer palestras”; “dão sopa, leite quente em dias de calor...deveria ter bancos...a gente come em pé; precisamos de um suco um dia sim e um não...nos ajude, pelo amor de Deus”; “eu gostaria que incluíssem sucos na dieta escolar”; "tirar a sopa do cardápio e dar suco natural para que tenha, pelo menos, prazer em comer”

Alunas

“criar na escola a Semana da Educação Alimentar”; “orientar de forma dinâmica"; "variar a merenda de acordo com os horários dos intervalos”; "dar fruta na hora do recreio”; “cozinhar menos os alimentos para não ficarem todos grudados; dá nojo; engrossar mais o caldo da sopa; por sal e tempero"; "melhorar muito a cantina, pois os alimentos que têm não são saudáveis”; “de manhã deveriam dar frutas ou até bolacha de sal com um copo de leite...a cantina só vende porcaria. Se ela vendesse sucos naturais e frutas ou até um pão mais saudável eu compraria com satisfação... eu me sinto mal de ver os colegas comendo comidas que não lhe trazem nenhum benefício. Eu amo comidas naturais, não vivo sem algum legume ou verdura e não tomo refrigerante há mais de um ano. Estou feliz comigo mesma e espero que essa pesquisa consiga realmente reverter essa situação, visando o bem estar e saúde de todos”; “dar uma aula por semana, ensinando sobre o que devemos comer”; “a escola pode fazer um programa de reeducação alimentar com um nutricionista”; "fazer teatros, espalhar cartazes pela escola, fazer apostilas para que os jovens regulem sua alimentação”.

\section{EPU - categoria C}

Alunos

“tirando a sopa está tudo bem”; “ensinar os alunos a não desperdiçar alimentos”; "nas sextas-feiras, bem que as escolas poderiam fornecer canjica, pudim de chocolate e 
salada de frutas...”; “não vender salgados gordurosos, balas e refrigerantes nas cantinas; vender sucos naturais”; "no bar da escola poderia vender outras coisas... só vende coisas que engordam; poderia ter suco, salada de frutas...”; “ eu não como merenda na escola por falta de higiene das merendeiras".

\section{Alunas}

“a escola deveria incentivar as cantinas a vender alimentos saudáveis: lanches e sucos naturais, frutas e outros”; “dar explicações sobre alimentação: como deve ser, explicar para comer o necessário...” “enriquecer o cardápio; não dar sopa de segunda a sexta-feira”; “a escola deveria dar aulas práticas; dar café da manhã na entrada”; “os professores podem dar mais orientações e os diretores proibirem a venda de coisas gordurosas e doces; escolas públicas só deveriam vender coisas saudáveis e nutritivas; os professores deveriam dar mais aulas sobre alimentos e ter palestras com nutricionistas”; “a cantina não tem nada além de salgadinhos, doces, balas e frituras; a merenda também tem que melhorar”; “dar palestras sugerindo para os alunos experimentarem coisas novas; não pode ser só uma no ano como acontece (se acontece...)”; "os professores deveriam ensinar mais sobre educação alimentar, pois hoje nós não temos muito essa orientação”.

\section{EPU Rural}

Alunos

“trazer nutricionistas para dar palestras”; “melhorar a merenda”; “ensinar mais sobre alimentos"; “a escola deveria fazer uma semana especial para educar mais os alunos sobre como ter alimentação saudável; a semana deveria se chamar Alimente-se bem”.

Alunas

"a merenda deveria ser adequada para os alunos de todos os turnos”; “as cantinas existentes nas escolas deveriam vender alimentos mais nutritivos”. 


\section{EPA - categoria $\alpha$}

Alunos

“pode-se, ao invés de lanches gordurosos e frituras, vender lanches naturais, ao invés de vender refrigerantes, passar a vender sucos de frutas naturais... melhorar o tipo de alimentação que se vende na escola"; "vender produtos naturais na cantina e dar algumas aulas sobre o assunto"; "ter uma nutricionista na escola para orientar os alunos”; deveriam reforçar bem a idéia de se alimentar bem em todas as séries”; “poderiam promover debates”.

Alunas

“a escola deveria dar palestras sobre alimentos e a cantina ter alimentos mais saudáveis”; “é necessário que a escola mostre aos alunos a importância da alimentação correta e a partir daí, com o auxílio da família, o jovem faça a escolha certa”.

\section{EPA - categoria $\beta$}

Alunos

"na cantina deveria ter alimentos naturais e estudar sobre alimentos no período de aulas”; "acho que as escolas podem criar um programa sobre ajuda nutricional e tentar tornar a cantina o mais saudável possível”; “dar palestras com pessoas especializadas no assunto”; “eu acho que, pelo menos, uma vez por mês deveria ter uma aula sobre educação alimentar”; “já pedimos à diretora e ela se recusou a vender lanches naturais...”; “colocar nas cantinas da escola mais coisas necessárias para manter a saúde como sucos ao invés de refrigerantes, lanches naturais ao invés de salgados gordurentos, frutas diversas e alimentos mais nutritivos com menos calorias”.

Alunas

“dar palestras sobre educação alimentar e parar de vender alimentos muito gordurosos na cantina; cada dia deveria ser o dia de um alimento, assim todos aprenderiam a comer de tudo"; "tem que começar a cantina vendendo alimentos mais saudáveis e depois conscientizar os alunos sobre a importância deles”. 


\section{EPA - categoria $\chi$}

Alunos

“a escola deve fazer projetos sobre alimentação”; “a cantina deveria oferecer lanche e suco natural e não fornecer salgado frito”; “a escola só ajuda nos estudos; alimentação é tarefa dos pais”; "parar de vender frituras na cantina e outras coisas que não fazem bem à saúde”; “orientar sobre alimentação saudável”.

Alunas

"nas cantinas escolares deve ter lanches naturais, não ter porcarias como salgadinhos...”; "ter nutricionista que oriente sobre os lanches para vender na cantina e sobre uma dieta saudável em casa”; “dar aulas de culinária para ensinar receitas gostosas, práticas, baratas e nutritivas"; "vender produtos naturais como barras de cereais".

\section{Período noturno - alunos adultos da rede regular de ensino}

\section{EPU “N” categoria A}

Alunos

"eu acho que a escola deveria dar merenda porque tem pessoas que saem com pressa do serviço ou moram muito longe”; “deveria alimentar os alunos que precisam”; “deveria por lanche na hora do intervalo para nós”; “dar comida ou leite na entrada, para melhorar os estudos”; “deveria dar jantar à noite; estudo longe e não dá tempo de jantar; chego às 18 h do serviço; deveria dar arroz e feijão; é o suficiente”; “deveria dar comida à noite”;"fazer horta na escola”.

Alunas

“a escola pode ajudar dando merenda: legumes, verduras, sucos, arroz, feijão para alunos terem mais vida”; “orientar mais sobre o que convém comer”; “ensinar mais sobre o assunto".

\section{EPU “N” categoria B}

\section{Alunos}


"os professores deveriam ensinar os pais e os alunos sobre como ter uma alimentação saudável e nutritiva para manter os alunos sem fome, porque com a barriga vazia não consegue pensar”; “a escola poderia dar uma salada na hora do intervalo e não vender comida que dá colesterol”.

Alunas

“a escola poderia dar fruta, suco; aqui não tem nada à noite”; “a escola precisa começar dar merenda à noite, pois tem muita gente que vem para a escola sem jantar e tem muita gente que chega em casa e dorme sem jantar por falta de comida”; "dar uma aula sobre alimentação ";”eu acho que os professores deveriam participar mais da vida do aluno; o aluno irá se sentir mais seguro e passa a confiar mais no professor”; “a escola precisa dar mais aulas sobre alimentação adequada, porque muitos alimentos que comemos prejudicam nossa saúde, levando à obesidade, colesterol e outras doenças”.

\section{EPU “N” categoria C}

\section{Alunos}

“a escola só dá sopa; eu queria um cardápio diferente”; “desde uns três meses a escola só dá sopa; precisamos de verduras, legumes, arroz, feijão, frutas, sucos naturais”; "por nutricionista na cozinha junto com as cozinheiras para controlar os alimentos servidos para os alunos”; “deveria haver palestras sobre a alimentação no dia-a-dia”.

Alunas

“deveriam dar umas frutas para nós”; “orientar mais sobre o que comer”.

\section{Período noturno - alunos adultos da educação supletiva}

\section{EPU “S” - categoria A}

Alunos

“a escola deveria dar alimentos que matassem a fome; só bolacha não sustenta”; “a escola precisa orientar pais de alunos e professores”.

Alunas 
“dar comida na hora do intervalo; muitas pessoas vêm para a escola sem jantar; saem do serviço e já vêm direto para a escola"; "fazer campanhas nas escolas, com muita propaganda, tentando incluir a família”.

\section{EPU “S” - categoria B}

Alunos

"é preciso saber o que se deve comer e quando comer; então acredito que precisamos de educação alimentar”; “dar palestras com nutricionistas”.

Alunas

“deveriam dar mais explicações sobre reeducação alimentar e mais atenção para a obesidade infantil”

\section{EPU “S " - categoria C}

Alunos

“dar comida para as pessoas que não têm tempo de jantar em casa”; "poderia orientar sobre como ter bons hábitos alimentares; para isso poderia criar um trabalho social, fazendo hortas para que as crianças peguem gosto pelo trabalho”.

Alunas

"ter jantar na escola”; “orientar mais os alunos”; "melhorar a cantina”

De maneira geral, os alunos demonstram necessitar de mais orientações por parte dos professores ou de nutricionistas quanto a educação alimentar e nutricional; os do diurno pedem para que o cardápio da merenda seja mais variado e adequado ao horário em que será servido e os do noturno, que a merenda seja servida também a eles ; a maioria, de ambos os períodos, de ambos os sexos, das diferentes categorias de escolas públicas e particulares, se diz preocupada com os alimentos e bebidas vendidos na cantina; têm consciência de que não são os recomendados pelo valor nutricional; pedem para que se venda frutas, sucos e lanches naturais; demonstram satisfação e agradecem pela oportunidade de expressar seus pensamentos, pedindo providências para que possam ser melhor atendidos. Parece-nos injusto que os alunos trabalhadores que 
freqüentam o período noturno não recebam algum alimento, pois muitos vão `a escola com sacrifício, diretamente do trabalho. Se a orientação é para ingestão de alimentação variada, é interessante se repensar o que servir na merenda escolar; uma aluna sugeriu, nessa pesquisa, que se coloque os alimentos na mesa e que os alunos sejam orientados, para aprenderem no dia-a-dia e, na prática, sobre as porções que convém por em seus pratos, para estarem bem nutridos; os professores podem colaborar neste sentido, orientando os alunos de acordo com os guias de recomendações nutricionais como a pirâmide alimentar, de acordo com Phillipi, 1998.

Essa pirâmide recomenda a ingestão diária de 5 a 9 porções de cereais, pães, tubérculos e raízes, 4 a 5 porções de hortaliças, 3 a 5 porções de frutas, 1 porção de leguminosas, 1 a 2 porções de carnes e ovos, 3 porções de leite e produtos láteos, 1 a 2 porções de óleos e gorduras e 1 a 2 porções de açúcares e doces.

O interessante da pirâmide é que orienta quanto a qualidade e quantidades dos alimentos a ingerir diariamente, além de ser de fácil visualização e entendimento.

A pirâmide alimentar pode funcionar como um instrumento para discussão da alimentação e nutrição em sala de aula. O professor pode discutir as necessidades nutricionais , o acesso ao alimento, as condições de segurança alimentar e nutricional, bem como a influência da propaganda e da televisão nas decisões de consumo das crianças, jovens e também adultos. É possível ainda valorizar o programa de merenda escolar e promover a participação dos pais no projeto pedagógico da escola a partir do envolvimento transdisciplinar de todos com a educação, saúde e o consumo como temas transversais do currículo do ensino fundamental.

Pode-se constatar pelas sugestões e falas neste trabalho apresentadas, que os alunos enxergam o que, muitas vezes, os profissionais da educação e/ou da saúde não vêem, ou, comodamente, fecham os olhos para não se comprometer. É uma incoerência os professores falarem, ainda que minimamente, a respeito do que convém ingerir e as cantinas escolares oferecerem apenas frituras, salgadinhos embalados, bebidas artificiais gaseificadas e junk-foods, muitas vezes adquiridos pelos próprios docentes que ministram aquelas aulas. 
É outra incoerência e, talvez a mais séria, existir uma legislação que estabeleça os temas transversais para as diretrizes curriculares nacionais e que sejam, muitas vezes, ignorados ou vistos com muita simplificação pelos profissionais da educação. É necessário que os cursos de formação de professores passem também a incluir esta temática em seus currículos.

A partir desse banco de dados buscou-se fazer uma reflexão sobre alguns aspectos, entre tantos outros possíveis, a respeito do comportamento alimentar dos diferentes grupos de alunos analisados . Espera-se contribuir de alguma forma para embasamento de estudos posteriores e, quem sabe, para uma intervenção consciente na realidade.

Não se pretendeu avaliar neste trabalho, as porções nem a qualidade dos alimentos ingeridos, em termos de valores nutricionais. 


\section{CONCLUSÕES}

Prevalece até os nossos dias a dominação nas escolas; os alunos não têm sido convidados a opinar e quando excepcionalmente isso acontece, não têm sido ouvidos.

A maioria deles alimenta-se várias vezes ao dia, como o desejável; os dados mostram semelhanças entre os diferentes grupos de alunos, quanto às escolhas da maior parte dos alimentos.

Sabe-se que muitos fatores intrínsecos e extrínsecos interferem nos hábitos alimentares da população em estudo; não se pode precisar ainda até que ponto é estatisticamente significativa a influência do nível social nos hábitos alimentares; vê-se, nessa pesquisa, que a maior parte das escolhas de alimentos é a mesma nas diferentes categorias de escolas públicas e particulares, do período diurno e noturno, de zona urbana e rural, do sexo masculino e feminino, da rede regular e da educação supletiva.

Pode-se perceber que há um certo padrão na seleção dos alimentos, tanto pelos alunos adolescentes do período diurno, quanto pelos alunos do noturno, muitos já adultos e trabalhadores.

No café da manhã a preferência do alunado é por café com leite e pão com manteiga na zona urbana; na rural não priorizam a manteiga, mas ingerem bolo, onde ela é um dos ingredientes; bolachas também são incluídas.

No almoço e jantar são líderes nas escolhas o arroz e feijão; há também considerável inclusão de verduras cruas e carnes. Infelizmente, os refrigerantes fazem parte dessas refeições, em percentuais elevados.

Nos intervalos entre as principais refeições, os alunos consomem, preferencialmente, bolachas, seguidas de salgadinhos, doces, frutas e lanches, no período da manhã e bolachas, frutas, doces, leite, bolo e lanches à tarde. 
Os assuntos alimentos e nutrição, pelas informações dos alunos e confirmando nossa hipótese, não vêm sendo trabalhados a contento, dentro do tema transversal Saúde, em todas as séries do ensino fundamental. Em escolas públicas com ensino regular diurno e noturno em zona urbana, têm mais ênfase na sexta série; nas escolas particulares, nas públicas de zona rural e na educação supletiva, esta em período noturno, são mais enfocados na sétima.

Os alunos informam ainda que os professores que mais têm desenvolvido o tema são os de Ciências, seguidos pelos de Educação Física e Português; os alunos da educação supletiva enfatizam também as aulas de Matemática, provavelmente por iniciativa particular de algum professor sensibilizado pelo assunto.

Foi possível perceber que os estudantes de escolas públicas da rede regular de ensino diurno são os que mais demonstram ter conhecimentos quanto ao que seja um cardápio adequado , seguidos por alunos de escolas particulares e os alunos de zona rural. No período noturno, os alunos da educação supletiva demonstram conhecer o assunto, enquanto que, na rede regular de ensino, também freqüentada por alunos adultos em sua maioria, o percentual é menor.

Os alunos apontam a família como o maior fator de influência na formação de seus hábitos alimentares.

Quanto ao Índice de Massa Corporal (I.M.C.), a maioria dos alunos se encontra dentro da faixa de normalidade.

Os alunos que demonstram estar mais satisfeitos com sua massa corporal são os que estão com sub-peso ; entre esses há os que ainda pensam que precisam emagrecer e outros que têm consciência que devem engordar; são seguidos no grau de satisfação consigo mesmos, pelos que estão na faixa de normalidade; entre esses últimos, mais da metade estão satisfeitos, mas há muitos que pensam que precisam emagrecer; os menos satisfeitos são os que têm peso acima da normalidade ,com grande parte tendo consciência que precisa emagrecer.

A escola é um meio socialmente aceito de educação formal e, se nesse espaço puder ser trabalhada a educação alimentar e nutricional de forma transdisciplinar, por todos os docentes, poderá resultar em muito benefício à saúde dos alunos. É interessante 
lembrar que existe interesse por parte deles e que o bom exemplo dos professores é fundamental; podem mostrar aos alunos que levam uma fruta como lanche, não devem comprar frituras e bebidas gaseificadas na cantina e a direção da escola deve evitar no estabelecimento, que haja dicotomia entre a teoria e a prática, por quem quer que seja, na cantina ou fora dela, por todos os professores e funcionários que fazem parte do diaa-dia dos alunos. O comportamento da equipe de trabalho deve promover as metas educacionais da escola, sobretudo no que se refere à educação alimentar e nutricional, com base numa uma cidadania ativa, que entenda o cidadão como alguém que cumpre deveres, mas que tenha seus direitos garantidos; que seja alguém capaz de interpretar a realidade em que vive e que, além de sofrer as conseqüências do meio, possa, numa relação dialética, nele interferir conscientemente e com competência, causando transformações que venham beneficiar a si próprio e a toda a sociedade. 


\section{REFERÊNCIAS BIBLIOGRÁFICAS}

BOOG, M.C.F. Educação Nutricional: passado, presente, futuro. Revista de Nutrição, v.10, n.1, p.5-19, 1995.

BOSLEY, B. Nutrition education. In: BEATON, G.H.; BENGOA, J.M. Nutrition in preventive medicine: the major deficience syndromes, epidemiology and aproaches to control. Geneva: World Health Organization, 1976. p.276-296 (Monograph Series, 62) .

BRASIL. Ministério da Educação. Constituição da República Federativa do Brasil 1988. Brasília, 1989.

BRASIL. Ministério da Marinha de Guerra, do Exército e da Aeronáutica- Decreto- Lei 986/69 - cria normas básicas para alimentos e bebidas. Brasília: Diário Oficial da União de 21/10/69 p.8935, retificado no de 11/11/69 p.97.

BRASIL. Ministério da Educação e do Desporto. Lei Federal 4024/61- Diretrizes e Bases da Educação Nacional. Rio de Janeiro: Secretaria da Educação, 1961.

BRASIL. Ministério da Educação e do Desporto. Lei Federal 5692/71 - Diretrizes e Bases da Educação Nacional. Brasília: Secretaria da Educação, 1971. 
BRASIL - Ministério da Educação e do Desporto . Lei Federal 7044/82 - altera dispositivos da Lei Federal 5692/71. Brasília: Secretaria da Educação,1996.

BRASIL. Presidência da República. Lei 9782 de 26/01/99 - define o sistema nacional de vigilância e cria a Agência Nacional de Vigilância Sanitária - ANVISA. Brasília, 1999.

BRASIL. Presidência da República - Lei 8078/90 - dispõe sobre a proteção do consumidor e dá outras providências. Brasília, Diário Oficial da União de 12/9/90.

BRASIL. Ministério da Educação e do Desporto. Lei Federal 9394/96 - Diretrizes e Bases da Educação Nacional. Brasília: Secretaria da Educação, Diário Oficial da União de 23 de dezembro de 1996.

BRASIL. Ministério da Educação e do Desporto. Parâmetros Curriculares Nacionais - Temas Transversais. Brasília: Secretaria de Educação Fundamental, 1998. 436p.

BRASIL. Ministério do Planejamento. Portaria 710/99- dispõe sobre Orçamento e Gestão - Alimentação Saudável . Brasília: Secretaria de Orçamento Federal, 1999.

CAROBA, D.C.R. A escola e o consumo alimentar de adolescentes matriculados na rede pública de ensino. Piracicaba, 2002. 162 p. Dissertação (Mestrado) - Escola Superior de Agricultura “Luiz de Queiroz”, Universidade de São Paulo.

DE ANGELIS, R.C. A importância de alimentos vegetais na manutenção da saúde. SãoPaulo, Atheneu, 1999.

D’INCAO, M.A. Amor e família no Brasil. São Paulo: Contexto, 1989.

Excel 2 000. Microsoft Office. 
FONSECA, V.M.; SICHIERI, R.; VEIGA, G.V. Fatores associados à obesidade em Adolescentes. Revista de Saúde Pública, v.32, n.6, p. 1-3, dez 1998.

FUNDAÇÃO INSTITUTO BRASILEIRO DE GEOGRAFIA E ESTATÍSTICA IBGE. Censo. 2000. 1v.

FUNDAÇÃO INSTITUTO BRASILEIRO DE GEOGRAFIA E ESTATÍSTICA IBGE. Pesquisa de Orçamento Familiar. 2002 e 2003.

GAMBARDELLA, A. M.D. Adolescentes, estudantes de período noturno: como se Alimentam e gastam suas energias. São Paulo, 1995. 65p. Tese (Doutorado) Faculdade de Saúde Pública, Universidade de São Paulo.

GAMBARDELLA, A..M.D. ; FRUTUOSO, M.F.P.; FRANCHI, C Prática alimentar de Adolescentes. Revista de Nutrição, v.12, n.1, p 55-63, jan./abr . 1999.

MONTEIRO, C.A.; MONDINI, L. ; COSTA, R.B.L. Mudanças na composição e adequação nutricional da dieta familiar nas áreas metropolitanas do Brasil de 1988 a 1 996. Revista de Saúde Pública, v.34, n.3, p. 1-14, jun.2000.

MORIN, E. Os sete saberes necessários à educação do futuro. São Paulo: Cortez, 2002.

MOYSES, M.; COLLARES, C. Educação ou saúde? Educação x saúde? Educação e Saúde! Cadernos Cedes, n.59, p. 7-16, 1995.

NIDELCOFF, M.T. Uma escola para o povo. São Paulo: Brasiliense, 1970.

ORGANIZAÇÃO MUNDIAL DE SAÚDE ( O.M.S) - Tabela para análise do Índice de Massa Corporal (I. M.C), 2000. 
ORTIGOZA, S. A.G. O fast food e a mundialização do gosto. Cadernos de Debate, v.5, p. 21-45, 1997.

PERECIN, M.T.G. O Instituto Baronesa de Rezende de Piracicaba. Piracicaba: Shekinah Editora e Gráfica, 1993.

PHILLIPI, S.T. Pirâmide dos alimentos . São Paulo: USP, 1998.

PIPITONE, M. A .P. Educação nutricional no ensino de ciências e no livro didático Piracicaba: ESALQ/USP, 2003. p.76-88.

PIPITONE, M.A.P. Notas sobre o programa de alimentação escolar como objeto de pesquisa. Salusvita, v.18, n.1, p.97-106, 1999.

PIPITONE, M.A. P. Educação nutricional: o interesse dos escolares Higiene Alimentar v.19, p.12-19, abr. 2005.

PIPITONE, M.A. P . ; STURION, G.L. A educação do consumidor no ensino de $1^{\circ}$ e $2^{\circ}$ Graus. Oikos, v.7, n.2, p.53-56.

PIPITONE, M.A. P.; SILVA, M.V.; STURION, G.L. A educação nutricional na escola pública de $\mathbf{1}^{\circ}$ grau - Relatório de pesquisa Fapesp, 1999.

PIPITONE, M.A.P.; SILVA, M.V.; STURION, G.L.; CAROBA, D.C.R. A educação nutricional nos livros didáticos de ciências utilizados no ensino fundamental Piracicaba: ESALQ/USP, 2004.

SAVIANI, D. Escola e democracia. São Paulo: Cortez, 198395 p. 
SETTON, M.G.J. Família, escola e mídia : um campo com novas configurações.

Educação e Pesquisa, v.28, n.1, p.107-116, jan./jun. 2002.

SILVA, M.V. Consumo de alimentos, programas de suplementação e estado nutricional de escolares. Piracicaba: ESALQ/USP, 2000.

SILVA, M.V. Estado nutricional de alunos matriculados em escolas públicas de tempo Integral - São Paulo, Brasil. Archivos Latinoamericanos de Nutricion , v.48, n.1, p.18-24, 1998.

SPYCKERELLE, Y.; HERBERT, B.;DESCHAMPS, J.P. Comportments alimentaires à l’adolescence. Cahier de Nutricion et Diétetique, v.26 p.426-431, 1991.

STRASGURGER, V.C. Os adolescentes e a mídia - impacto psicológico. Porto Alegre: Artes Médicas Sul, 1999.

VALENTE,F.L.S. Fome e desnutrição: determinantes sociais. São Paulo: Cortez, 1989. p.33-37.

VIEIRA, S.; SAAD,W. Metodologia científica para a área de saúde. Campinas: Ed.UNICAMP, 2001.

WHITE, O .M. Considerações gerais sobre o ato de compra por parte do préAdolescente. São Paulo, 1997206 p. Dissertação (Mestrado). Faculdade de Economia, Administração e Contabilidade, Universidade de São Paulo.

ZIWIAN, Z.L.J. Educação na adolescência- Importância do comportamento alimentar na Busca de saúde pública. Higiene Alimentar, v.13, n.61, abr./mai.1 999. 
ANEXO 
ESTUDO DE OPINIÃO SOBRE ALIMENTOS - Piracicaba (SP), 2004.

Após preencher a parte inicial, leia atentamente cada questão e, por favor, responda com sinceridade, o que você come normalmente, no dia-a-dia. Mesmo não tendo o seu nome, em o nome de sua escola, garanto-lhe que estas respostas serão vistas apenas por mim, que desenvolvo uma pesquisa junto a ESALQ.

Você estuda na série do Ensino Fundamental

Idade:

$\begin{array}{lll}\text { Período }(\quad) \text { diurno } & (\quad) \text { noturno } \\ \text { No ensino } & (\quad) \text { regular } & (\quad) \text { supletivo } \\ \text { Em zona } & (\quad) \text { urbana } & (\quad) \text { rural } \\ \text { Escola } & (\quad) \text { pública } & (\quad) \text { particular }\end{array}$

Sexo:

Altura:

1-Você: （ ） toma o café da manhã （ ） não toma o café da manhã

2- Se toma, assinale o que consome nesse horário:

$\begin{array}{lll}\text { ( ) café } & \text { ( ) pão } & \text { ( ) manteiga } \\ \text { ( ) leite } & \text { ( ) bolacha } & \text { ( ) margarina } \\ \text { ( ) chá } & \text { ( ) bolo } & \text { ( ) presunto } \\ \text { ( ) suco natural de fruta } & \text { ( ) biscoito } & \text { ( ) mortadela } \\ \text { ( ) suco artificial } & \text { ( ) queijo } & \text { ( ) ovos } \\ \text { ( ) iogurte } & \text { ( ) requeijão } & \text { ( ) fruta }\end{array}$

3-Entre o café da manhã e o almoço você come:

$\begin{array}{llll}\text { ( ) salgadinhos } & \text { ( ) bolacha } & \text { ( ) café } & \text { ( ) chá } \\ \text { ( ) lanche } & \text { ( ) doce } & \text { ( ) leite } & \text { ( ) nada } \\ \text { ( ) fruta } & \text { ( ) pipocas } & \text { ( ) suco natural } & \\ \text { ( ) bolo } & \text { ( ) batatas fritas } & \text { ( ) suco artificial } & \end{array}$

4-No almoço costuma comer, na maioria das vezes:

$\begin{array}{llll}\text { ( ) arroz } & (\text { ) verduras cruas } & \text { ( ) peixe } & (\text { ) frango } \\ \text { ( ) feijão } & (\text { ) legumes crus } & \text { ( ) sopa } \\ \text { ( ) macarrão } & (\text { ) carne de vaca } & \text { ( ) lanche } \\ \text { ( ) verdura cozida } & \text { ( ) carne de porco } & \text { ( ) embutidos (lingüiça, salame...) } \\ \text { ( ) outro alimento. O quê? }\end{array}$

5-O que bebe nas refeições todos os dias?

( ) água ( ) refrigerante ( ) suco de frutas ( ) suco artificial ( ) leite ( ) café ( ) não tomo nada

6- Entre o almoço e jantar você geralmente come:

$\begin{array}{lll}\text { ( ) salgado } & \text { ( ) bolacha } & \text { ( ) café } \\ \text { ( ) lanche } & \text { ( ) doce } & \text { ( ) leite } \\ \text { ( ) fruta } & \text { ( ) suco de fruta natural } & \text { ( ) chá } \\ \text { ( ) bolo suco de fruta artificial } & \text { ( ) não como nada nesse intervalo } \\ \text { ( ) como outro alimento. O quê? } & \end{array}$


7-No jantar do dia-a-dia você costuma consumir:

$\begin{array}{lll}\text { ( ) arroz } & (\text { ) verduras cruas } & \text { ( ) peixe } \\ \text { ( ) feijão } & (\text { ) legumes crus } & \text { ( ) sopa } \\ \text { ( ) macarrão } & (\text { ) carne de vaca } & \text { ( ) lanche } \\ \text { ( ) verdura cozida } & (\text { ) carne de porco } & \text { ( ) não costumo jantar } \\ \text { ( ) legumes cozidos } & (\text { ) carne de frango } & (\quad \text { ) outro alimento. }\end{array}$

Se come outro alimento, o quê?

8-Toma alguma bebida diariamente na hora do jantar?

( ) não

( ) sim ( )água ( )refrigerante ( )suco natural ( )suco artificial ( )leite ( ) café

9-Marque número 1 no fator que mais interferiu na formação de seus hábitos alimentares; número 2 no segundo fator e número 3 no que interferiu menos
( ) escola
( ) família
( ) televisão

10-Em quais séries você estudou o assunto Alimentos na escola?

( ) $1^{\mathrm{a}}$ série () $2^{\mathrm{a}}()^{\mathrm{a}}() 4^{\mathrm{a}}()^{\mathrm{a}}() 6^{\mathrm{a}}() 7^{\mathrm{a}}() 8^{\mathrm{a}}$ série.

11-Se estudou, professor(es) de que matéria(s) lhe deram orientações ?

$\begin{array}{llll}\text { ( ) Português } & (\text { ) Matemática } & (\text { ) Ciências } & (\text { ) História } \\ \text { ( ) Geografia } & (\text { ) Inglês } & (\text { ) Ed Física } & (\text { ) nenhum }\end{array}$

12-Dê exemplo de um cardápio que considera completo para um almoço

13-Você acha que seu peso:

( ) está abaixo da média e precisa engordar

( ) está acima da média e precisa emagrecer

( ) está bom

14-Dê sugestões sobre o que a escola pode fazer para ajudar mais os jovens, quanto a Educação Alimentar; sinta-se à vontade; use também o verso, se necessário. Agradecemos sua participação. 